UNIVERSIDADE DE SÃO PAULO

ESCOLA POLITÉCNICA

DEPARTAMENTO DE ENGENHARIA DE MINAS
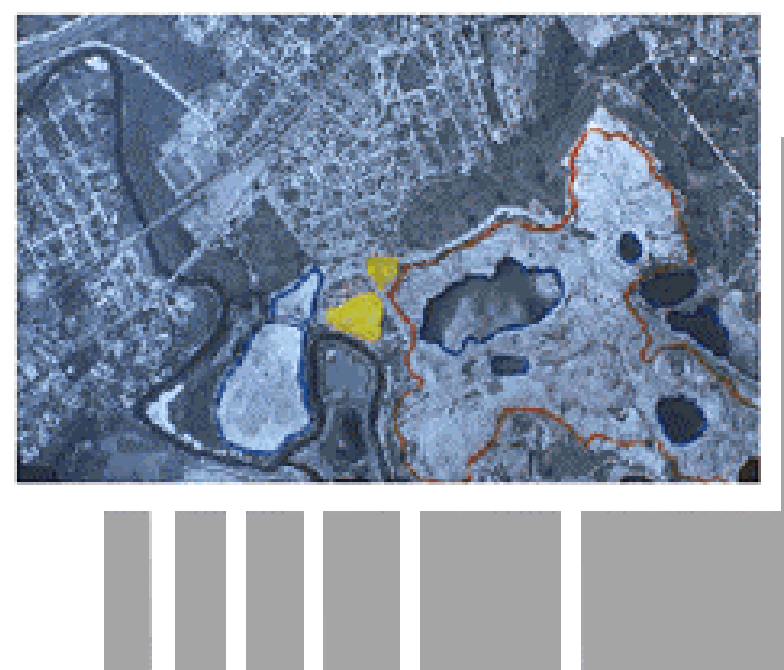

AVALIAÇÃO DA RECUPERAÇÃO DE ÁREAS DEGRADADAS POR MINERAÇÃO NA REGIÃO METROPOLITANA DE SÃO PAULO

OMAR YAZBEK BITAR

SÃO PAULO

1997 
OMAR YAZBEK BITAR

\title{
AVALIAÇÃO DA RECUPERAÇÃO DE ÁREAS DEGRADADAS POR MINERAÇÃO NA REGIÃO METROPOLITANA DE SÃO PAULO
}

\author{
Tese apresentada à Escola Politécnica da \\ Universidade de São Paulo para obtenção do \\ título de Doutor em Engenharia. \\ Área de Concentração: Engenharia Mineral \\ Orientador: Prof. Dr. Arthur Pinto Chaves
}

São Paulo

1997 
Bitar, Omar Yazbek

Avaliação da recuperação de áreas degradadas por mineração na Região Metropolitana de São Paulo. São Paulo: 1997.

$185 \mathrm{p}$.

Tese (Doutorado) - Escola Politécnica da Universidade de São Paulo. Departamento de Engenharia de Minas.

1. Mineração - Controle ambiental. 2. Mineração - Áreas urbanas. 3. Mineração - Recuperação de áreas degradadas. 4. Mineração - Região Metropolitana de São Paulo. I. Universidade de São Paulo. Escola Politécnica. Departamento de Engenharia de Minas. II. t 
Cidinha, Gabriel e Nádia, pela compreensão e apoio 


\section{AGRADECIMENTOS}

- ao Prof. Dr. Arthur Pinto Chaves, pelo incentivo e permanente orientação;

- ao Prof. Dr. Luiz Enrique Sánchez, pelas sugestões e críticas apresentadas durante o desenvolvimento da pesquisa e no Exame de Qualificação;

- ao Prof. Dr. Sérgio Eston Médici, pelas recomendações no Exame de Qualificação;

- ao Prof. Dr. Milton Vargas, pela análise e sugestões ao plano original de pesquisa;

- ao Prof. Dr. Arley Benedito Macedo do Instituto de Geociências da Universidade de São Paulo- USP, Prof. Dr. Luiz Augusto Milani Martins do Instituto de Geociências da Universidade Estadual de Campinas- Unicamp, Pesquisador Dr. Waldir Lopes Ponçano do Instituto de Pesquisas Tecnológicas do Estado de São Paulo- IPT e geólogo Fernando Mendes Valverde do Departamento Nacional da Produção Mineral- DNPM, pelo incentivo e apoio manifestado à solicitação de auxílio àpesquisa;

- aos colegas da Divisão de Geologia- Digeo do IPT que colaboraram na realização da pesquisa, em particular a Nilton Fornasari Filho, Tânia de Oliveira Braga, Maria Marta T. Vasconcelos, Angelo José Consoni e Elvira Gabriela C. S. Dias, pelo convívio e discussões técnicas; a Vera Lúcia C. Costa e Sônia Regina Di Madureira pela coleta de dados e trabalhos de campo; a Nivaldo Paulon e Benedito Nachbal, pela geração de produtos cartográficos digitalizados; a Waldyr Dantas Cortez pelo tratamento digital de imagens fotográficas; e a Inês do Prado Consoni pelo apoio na pesquisa bibliográfica;

- aos colegas de pós-graduação no Departamento de Engenharia de Minas da Escola Politécnica da USP-PMI/Epusp, pela troca de experiências em seminários;

- a Maria Cristina Martinez Bonesio, da biblioteca do PMI/Epusp, pelo apoio na pesquisa e revisão das referências bibliográficas;

- aos profissionais que concederam entrevistas e forneceram informações, em particular a Ronaldo Malheiros Figueira, da Prefeitura Municipal de São Paulo- PMSP;

- ao PMI/Epusp, pela acolhida e apoio;

- ao IPT pelos recursos humanos e materiais oferecidos;

- à Fundação de Amparo à Pesquisa no Estado de São Paulo- Fapesp, pela concessão do auxílio que viabilizou a pesquisa e pelas recomendações apresentadas pelo consultor "ad hoc" nos relatórios parcial e final aprovados;

- æ̀s empresas de mineração que permitiram as visitas técnicas, possibilitando a coleta de dados e informações;

- aos órgãos públicos que disponibilizaram seus acervos para consulta, em particular ao Departamento de Avaliação de Impacto Ambiental- Daia e ao Departamento de Uso do Solo Metropolitano- DUSM, ambos da Secretaria de Estado do Meio Ambiente- SMA. 


\section{RESUMO}

Este estudo compreende uma avaliação de procedimentos e medidas de recuperação de áreas degradadas por mineração na Região Metropolitana de São Paulo- RMSP.

Inicialmente, apresenta-se o problema investigado e a hipótese que orientou a pesquisa. Destaca-se o caráter incipiente dos trabalhos de recuperação efetuados na RMSP e o papel relevante que poderiam ter em face do contexto urbano (Capítulo 1).

Descreve-se o método adotado na realização da pesquisa, ressaltando o levantamento de 42 minas ativas (17 de brita, 15 de areia, 4 de caulim, 3 de argila, 1 de calcário, 1 de quartizito e 1 de rocha ornamental), 11 minas desativadas e 54 antigas áreas de mineração atualmente ocupadas por outros usos, totalizando 107 áreas estudadas (Capítulo 2).

Apresenta-se um breve panorama mundial e nacional sobre o tema da recuperação de áreas degradadas por mineração. Inclui-se uma discussão sobre conceitos básicos, métodos e técnicas comumente empregados em minas ativas, usos pós-mineração freqüentes e instrumentos legais, institucionais e empresariais utilizados no planejamento e gerenciamento da questão (Capítulo 3).

Avaliam-se os procedimentos relacionados ao planejamento da recuperação na RMSP, tendo como referência a análise de 91 Planos de Recuperação de Áreas Degradadas- Prads relativos a minerações ativas e desativadas na RMSP (Capítulo 4).

As medidas de recuperação praticadas em minas ativas na RMSP são avaliadas quanto às finalidades desejadas, procedimentos adotados e desempenho obtido (Capítulo 5).

Discutem-se aspectos relacionados àinstalação de usos pós-mineração na RMSP, tendo como base o estudo em minas desativadas e a análise sobre a reabilitação de antigas áreas de mineração que se encontram atualmente ocupadas de forma desordenada ou planejada (Capítulo 6).

Ao final, sintetizam-se as conclusões gerais obtidas, contemplando os aspectos principais sobre as medidas de recuperação e a instalação de usos pós-mineração na RMSP (Capítulo 7). 


\begin{abstract}
This work deals with the assessment of mine reclamation procedures in the Sao Paulo Metropolitan Region (RMSP).

It begin with the presentation of the problem and of the hypothesis which orientated the research work. The very incipient character of the reclamation works is emphazised as well its potential role in urban areas (Chapter 1).

Chapter 2 describes the research method. 42 ative mines (17 of aggregate, 15 of sand, 4 of kaolin, 3 of clay, 1 of limestone and 1 of dimension stone) are studied in the RMSP. Other 11 inactive mines and 54 ancient mine sites are also studied.

An overview about mine reclamation is presented in the research. It includes some basic concepts, procedures about reclamation in urban areas and after-mining uses (Chapter 3 ).

91 plans for the reclamation mine (Prads) related to active and inactive mines in the RMSP are also studied (Chapter 4). Procedures for reclamation are evaluated with reference to the final results achieved (Chapter 5).
\end{abstract}

Aspects related to after-mining uses in the RMSP are discussed in Chapter 6.

Conclusions achieved are summarized in Chapter 7. 


\section{SUMÁRIO}

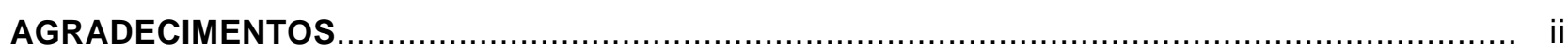

RESUMO

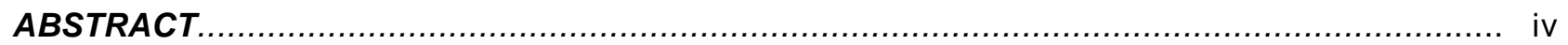

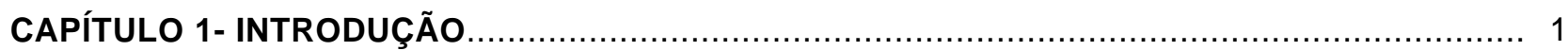

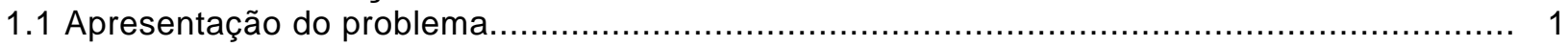

1.1.1 Características da produção mineral................................................................ 3

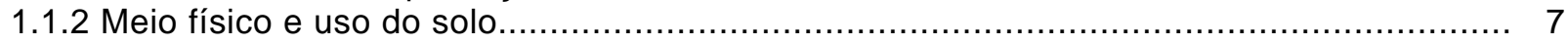

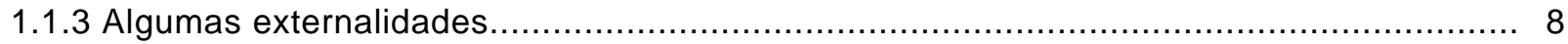

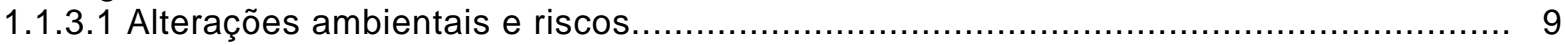

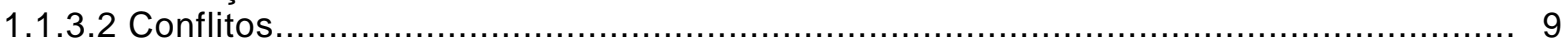

1.1.3.3 Depreciação de imóveis circunvizinhos........................................................... 10

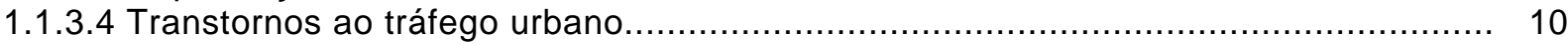

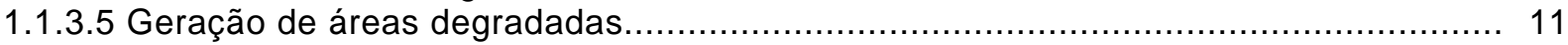

1.1.3.6 Ocupação desordenada de áreas degradadas................................................ 11

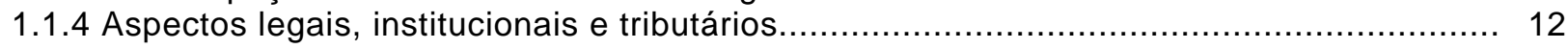

$1.1 .5 \mathrm{O}$ papel da recuperação de áreas degradadas....................................................... 14

1.2 Hipótese de trabalho e objetivo da pesquisa.............................................................. 15

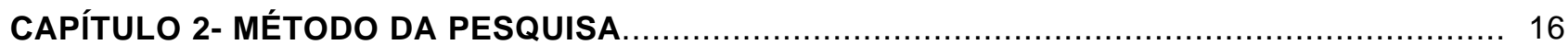

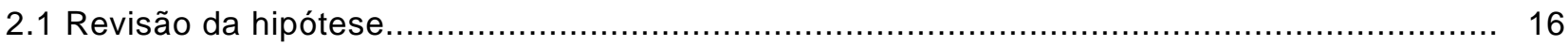

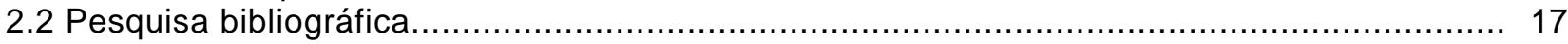

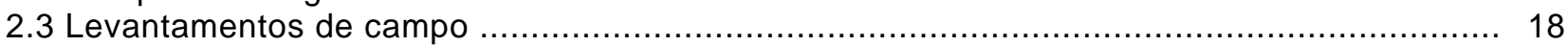

2.3.1 Critérios para a escolha de áreas................................................................... 18

2.3.2 Preparação da ficha de campo.................................................................. 19

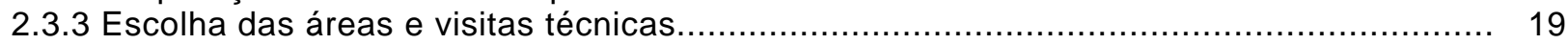

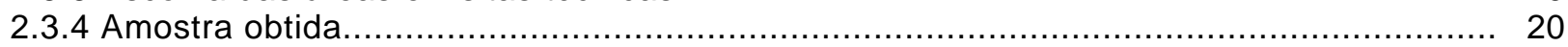

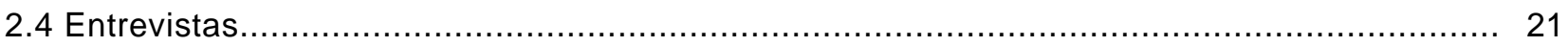

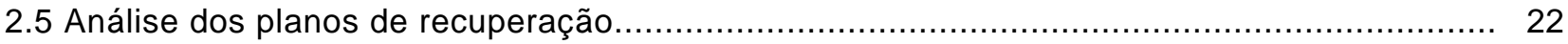

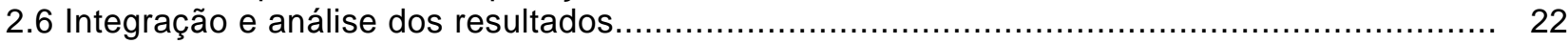

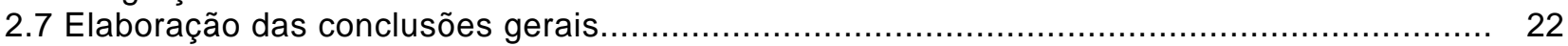

CAPÍTULO 3- PANORAMA DA RECUPERAÇÃO DE ÁREAS DEGRADADAS POR MINERAÇÃO.. 24

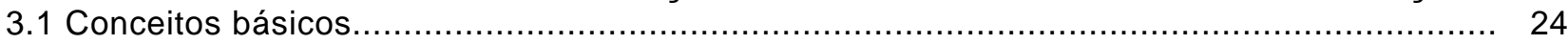

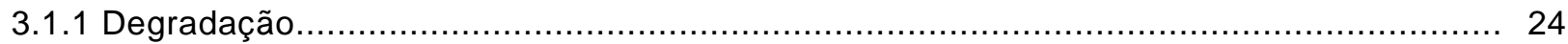

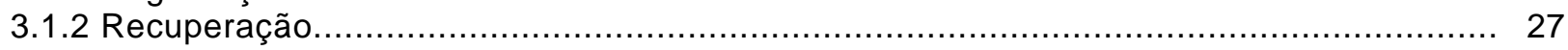

3.1.3 Integração e evolução dos conceitos.............................................................. 30

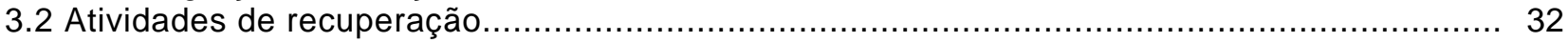

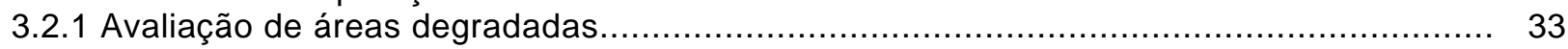

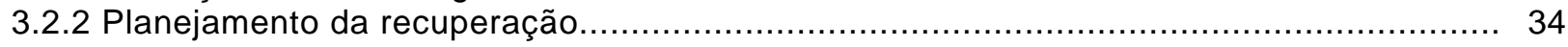

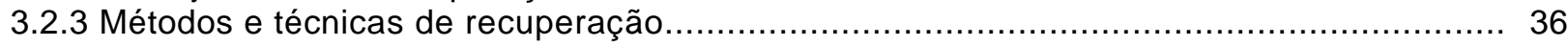

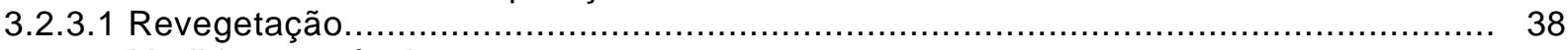

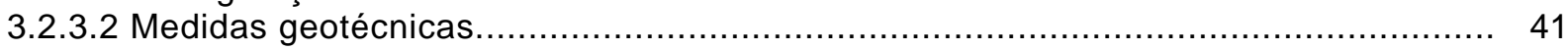

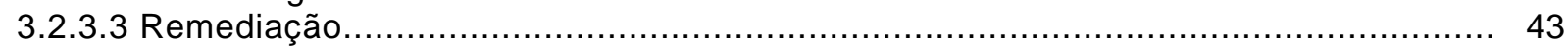

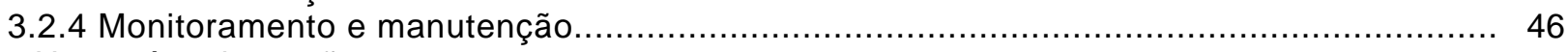

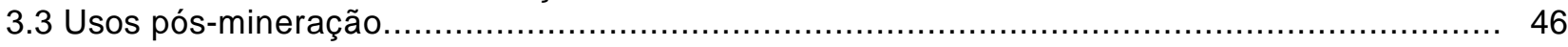

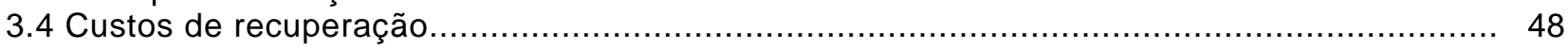

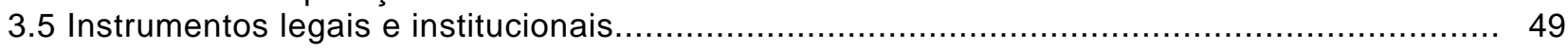

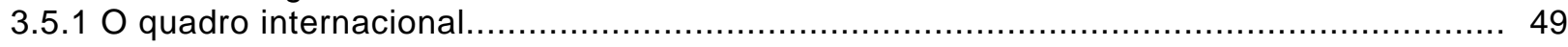

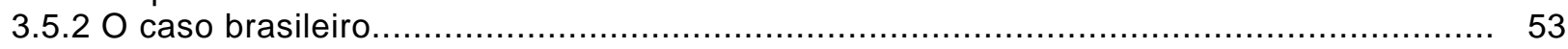

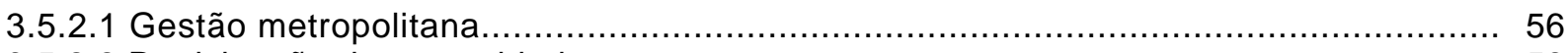

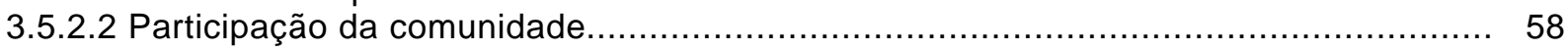

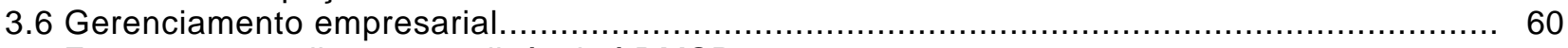

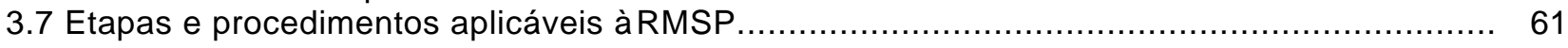

CAPÍTULO 4- PLANEJAMENTO DA RECUPERAÇÃO NA RMSP ........................................... 63

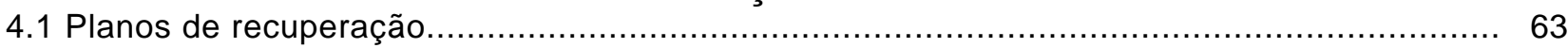

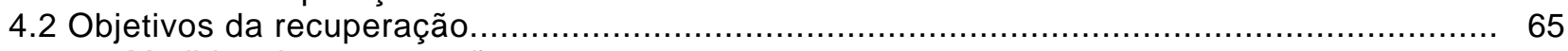

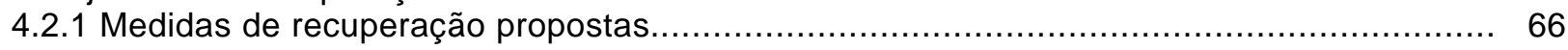




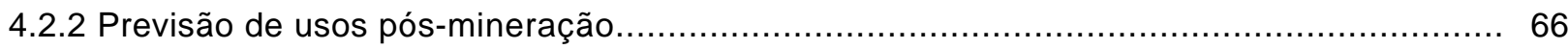

CAPÍTULO 5- MEDIDAS DE RECUPERAÇÃO EM MINAS ATIVAS NA RMSP $\ldots \ldots \ldots \ldots \ldots \ldots \ldots \ldots \ldots$

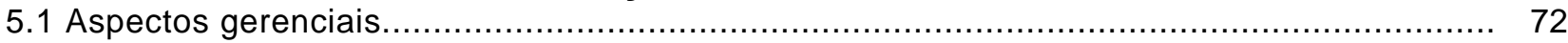

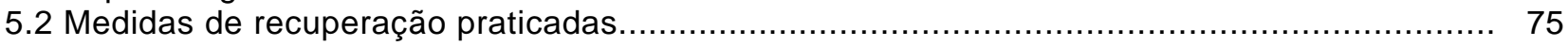

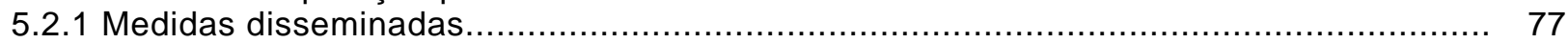

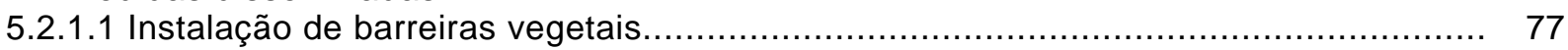

5.2.1.2 Arborização dispersa na área da mineração................................................... 78

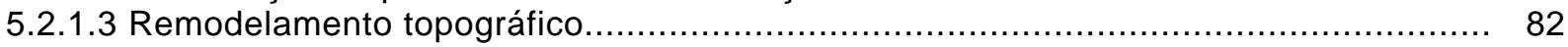

5.2.1.4 Retaludamento e revegetação de áreas lavradas............................................. 83

5.2.1.5 Revegetação de taludes de barragens de rejeito........................................... 84

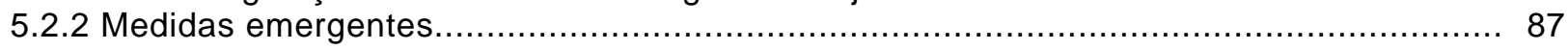

5.2.2.1 Remoção, estocagem e utilização da camada orgânica do solo superficial................. 87

5.2.2.2 Remoção, estocagem e utilização da camada argilosa do solo superficial................... 89

5.2.2.3 Remoção dirigida de estéreis e preenchimento de cavas...................................... 89

5.2.2.4 Instalação de sistemas de drenagem em barragens de rejeito................................ 93

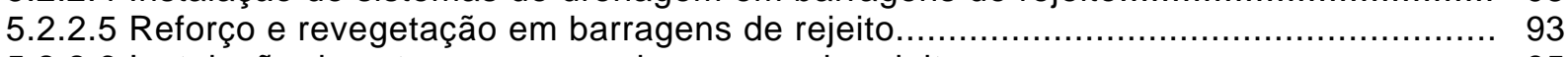

5.2.2.6 Instalação de extravasores em barragens de rejeito............................................ 95

5.2.2.7 Transposição de rejeitos de bacias de decantação para áreas lavradas....................... 95

5.2.2.8 Instalação de sistemas de drenagem e retenção de sedimentos............................. 97

5.2.2.9 Construção e estabilização de bota-foras......................................................... 103

5.2.2.10 Retenção e coleta de óleos e graxas.......................................................... 107

5.2.2.11 Revegetação de taludes em acessos e vias internas....................................... 107

5.2.2.12 Remoção de blocos rochosos instáveis em áreas lavradas................................... 111

5.2.2.13 Abatimento e revegetação de taludes marginais em lagos remanescentes................. 111

5.2.2.14 Proteção e manejo da vegetação remanescente................................................... 113

5.2.2.15 Indução e manejo da revegetação espontânea................................................. 113

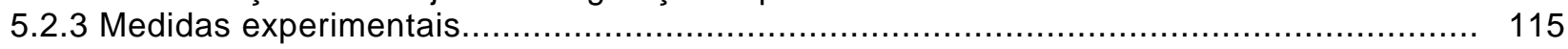

5.2.3.1 Revegetação em bermas e taludes rochosos................................................. 115

5.2.3.2 Revegetação em solos de alteração de rochas................................................ 118

5.2.4 Síntese do desempenho das medidas praticadas................................................. 118

CAPÍTULO 6- REABILITAÇÃO E USOS PÓS-MINERAÇÃO NA RMSP.................................. 119

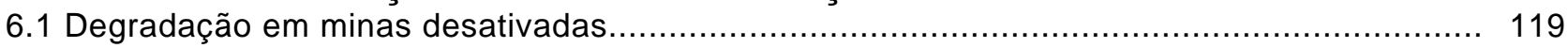

6.2 Uso do solo em antigas áreas de mineração................................................................ 125

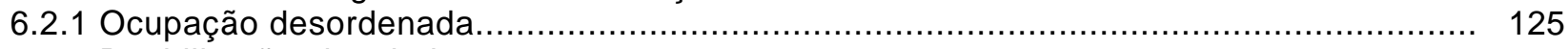

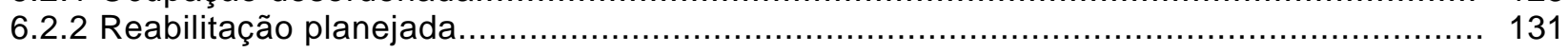

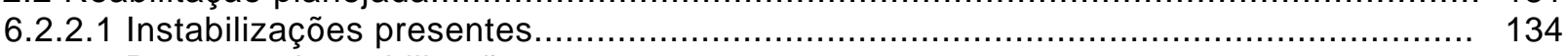

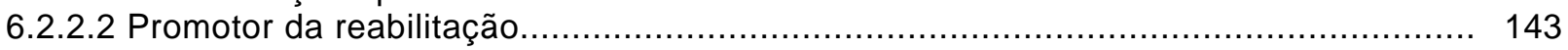

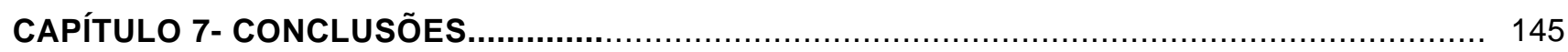

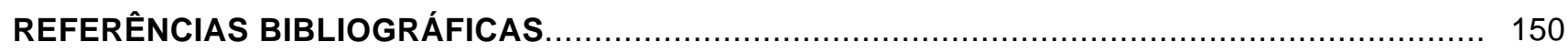

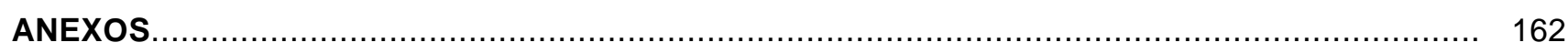

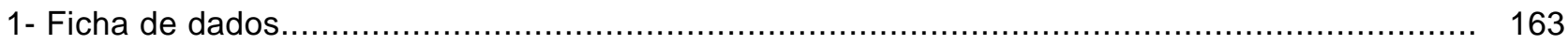

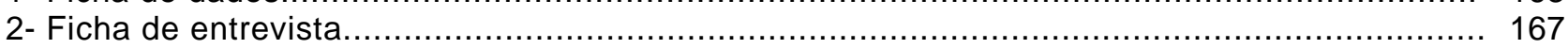

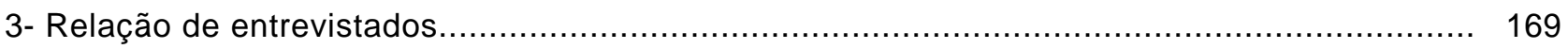

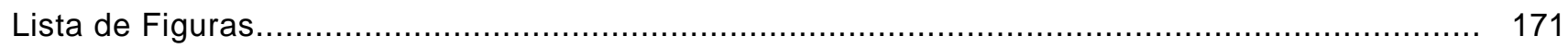

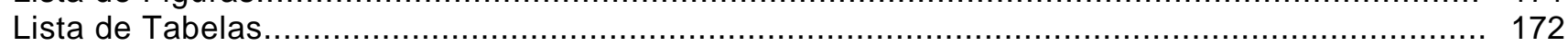

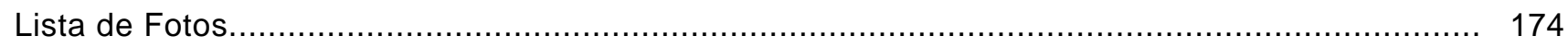

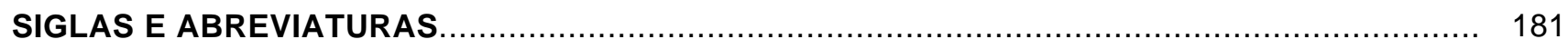

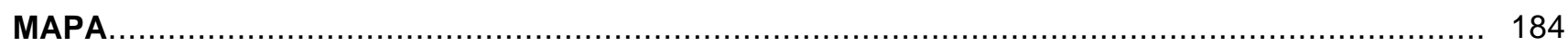

1- Localização das áreas estudadas na RMSP e contexto geotécnico...................................... 185 


\section{CAPÍTULO 1}

\section{INTRODUÇÃO}

Este Capítulo apresenta e descreve o problema investigado, explicitando as hipóteses de trabalho e definindo os objetivos que orientaram a realização da pesquisa.

\subsection{Apresentação do problema}

Estudo da Divisão de População da Organização das Nações Unidas- ONU (REGIÃO, 1993), revela que a Região Metropolitana de São Paulo-RMSP (FIGURA 1.1) é a $2^{\underline{a}}$ entre as metrópoles do mundo, com cerca de 19,2 milhões de habitantes, ficando atrás apenas de Tóquio, Japão, que tem 25,7 milhões. Apesar da divergência com os dados do Instituto Brasileiro de Geografia e Estatística (IBGE, 1994), cujo censo brasileiro de 1991 indicou cerca de 15,4 milhões de habitantes (aproximadamente 50\% da população do Estado de SP e 10\% da do País), a RMSP permanece entre as metrópoles mais populosas do mundo.

Abrangendo uma área de cerca de $8.051 \mathrm{~km}^{2}$, a RMSP compreende atualmente 39 municípios e seu crescimento populacional está diretamente relacionado ao intenso e acelerado processo de industrialização e urbanização verificado principalmente entre os anos 40 e 70 (SANTOS, 1993). Entre os principais fatores contributivos, destaca-se a disponibilidade de matérias-primas minerais de uso na construção civil, sobretudo areia, cascalho, argila, cimento e brita. A relativa abundância destes insumos, proporcionada pelas características geológicas da RMSP, bem como a proximidade dos locais de consumo, propiciou construir, a baixos custos financeiros, a imensa quantidade de edificações, obras públicas de infraestrutura e instalações industriais existentes hoje na metrópole.

No entanto, em decorrência das relações continuadas que se estabeleceram entre a mineração e a dinâmica de crescimento da metrópole, particularmente nas últimas décadas, emergiram conflitos de uso do solo e impactos ambientais, ressaltados pelo fato de que poucas empresas praticam suas atividades de modo a evitá-los.

A recessão econômica dos anos 80 e as incertezas da década de 90 limitaram a ampliação da capacidade instalada para a extração de minérios na RMSP, mantendo-a nos níveis da década de 70. Com isso, segundo estudos do Instituto de Pesquisas Tecnológicas do Estado de São Paulo- IPT, tem-se um parque produtor cujo padrão tecnológico ainda se encontra bastante defasado em comparação aos países industrializados, o que sugere poucas mudanças em relação ao equacionamento dos problemas ambientais (IPT, 1993). 
FIGURA 1.1 - Localização e dados gerais da RMSP - Ver Pasta Desenhos 


\subsubsection{Características da produção mineral}

A história da atividade mineral na RMSP neste século está ligada principalmente à produção de bens minerais de uso imediato na construção civil (KNECHT, 1950; ABREU, 1973; SÃO PAULO, 1982).

Estimativas sobre os montantes anuais produzidos nos últimos anos, em um total de 188 empreendimentos levantados pelo IPT no final da década passada, de acordo com o tipo de substância mineral e o respectivo número de minas, estão apresentados na TABELA 1.1.

TABELA 1.1- Produção anual e número de minas na RMSP, segundo a substância mineral.
Substância Mineral
Produção anual
№ de minas

\begin{tabular}{llc}
\hline Água Mineral & $31.705 .300 \mathrm{I}$ & 08 \\
\hline Areia para construção & $1.908 .585 \mathrm{~m}^{3}$ & 66 \\
\hline Areia e quartzito industrial & $138.768 \mathrm{t}$ & 09 \\
\hline Argilas & $515.392 \mathrm{t}$ & 46 \\
\hline Brita & $10.283 .335 \mathrm{~m}^{3}$ & 37 \\
\hline Rocha calcária & $1.308 .522 \mathrm{t}$ & 01 \\
\hline Rochas dimensionadas e aparelhadas & $9.312 \mathrm{~m}^{3}$ & 09 \\
\hline Outros bens minerais & $56.975 \mathrm{t}$ & 12 \\
\hline Total & & 188 \\
\hline Fonte: RUIZ, NEVES, 1990) & & \\
\hline
\end{tabular}

(Fonte: RUIZ, NEVES, 1990)

Apesar da abrangência do estudo do IPT, superando o número de 183 minas ativas cadastradas pela Empresa Metropolitana de Planejamento da Grande São Paulo- Emplasa (EMPLASA, 1989b), bem como o fato de representar o mais recente e completo levantamento sobre produção mineral efetuado na RMSP, convém salientar que os dados têm origem em estatísticas sobre arrecadação tributária do ano de 1988, portanto baseadas nas declarações formais apresentadas pelas empresas de mineração na época, o que recomenda cautela na sua utilização, uma vez que os valores reais podem ser bastante superiores.

Estimativas do Departamento Nacional da Produção Mineral- DNPM apontam a seguinte distribuição do valor econômico da produção mineral na RMSP: 75\% correspondentes a 
minerais "in natura" (55\% de rochas para produção de brita e $20 \%$ de areia para construção civil), $22 \%$ de minerais industriais $(9,5 \%$ de caulim, $6 \%$ de argilas plásticas e refratárias, $4,2 \%$ de quartzitos e $2,3 \%$ de outros bens minerais) e $3 \%$ de águas minerais.

Nota-se o expressivo significado econômico dos materiais "in natura", ou seja, bens minerais utilizados como agregados e de emprego imediato na construção civil, sobretudo brita e areia, responsáveis por $75 \%$ do total. Hoje, apesar da ausência de estatísticas disponíveis, a situação econômica dos últimos anos, especialmente no setor de construção civil, sugere que as proporções ainda estejam nos mesmos níveis (FIGURA 1.2).

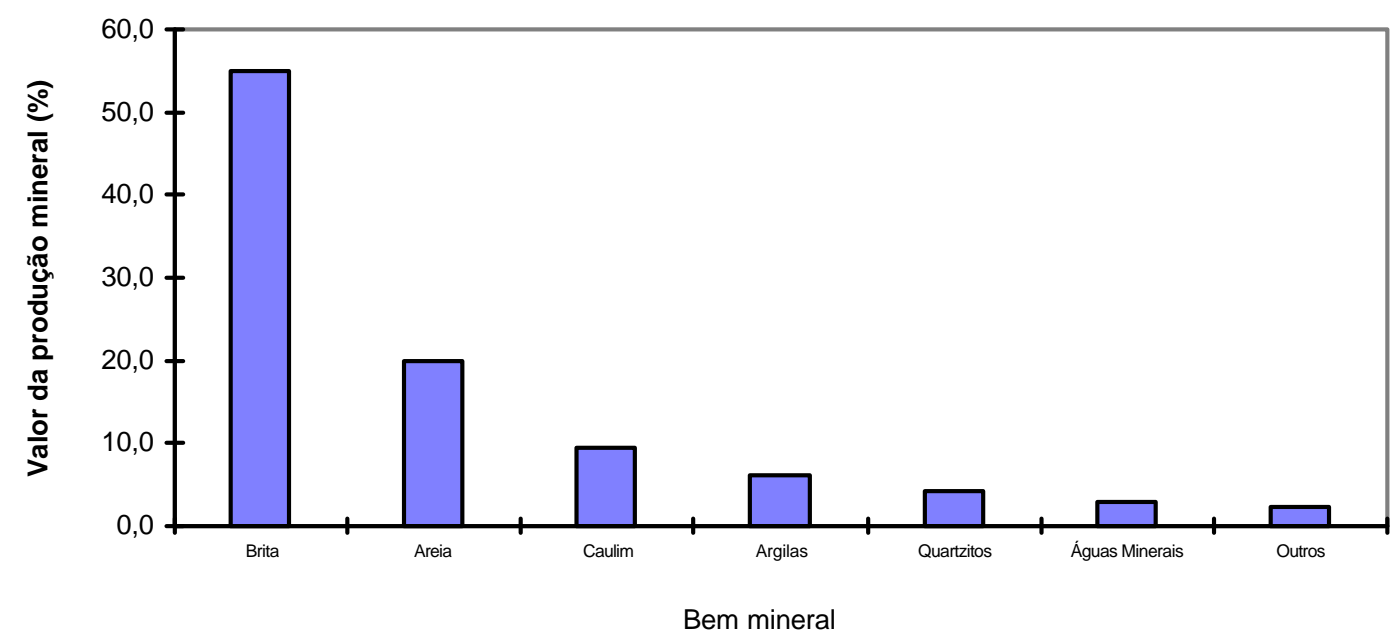

FIGURA 1.2- Distribuição do valor da produção mineral na RMSP (Fonte: VALVERDE et al., 1992).

Os métodos de produção variam em função do tipo de bem mineral e do contexto em que a jazida ocorre. Na RMSP, as etapas do processo produtivo mineiro geralmente compreendem o decapeamento, lavra, beneficiamento, disposição de estéreis e rejeitos, estocagem e transporte dos produtos e operações auxiliares.

No caso de areia, os métodos de produção em cavas secas de planícies aluvionares, colinas e morros são similares. Baseiam-se no decapeamento com uso de trator de esteira, escavadeira e pá-carregadeira, lavra por desmonte hidráulico, beneficiamento com uso de tanques de lavagem e classificadores, disposição de estéreis em pilhas, disposição de rejeitos em bacias de decantação, estocagem do produto em pilhas e transporte por caminhões. Em geral, a areia é classificada em fina, média ou grossa, podendo haver outras frações intermediárias. Em cavas inundadas, geralmente mais profundas do que as secas, sobretudo em planícies aluvionares, a lavra se realiza por meio de dragas de sucção instaladas em barcaças flutuantes, o mesmo ocorrendo nos raros casos de extração em leito de rio.

$\mathrm{Na}$ produção de argila em planícies aluvionares, os métodos geralmente se fundamentam na lavra por tiras, adequada às pequenas espessuras das camadas (cerca de 2,5 
m) e às grandes extensões em que ocorrem. Em alguns casos, o beneficiamento é realizado no próprio local da mina e compreende uma ou duas fases de moagem. Os estéreis e rejeitos do beneficiamento geralmente são dispostos nas cavas lavradas.

Na produção de brita e calcário, a lavra é realizada por desmonte rochoso, com uso de explosivos, formando bancadas. No caso da brita, sucedem-se várias fases de britagem e peneiramento, sendo que a estocagem é realizada com separação de pilhas de acordo com o tamanho da pedra obtida (pó de pedra; pedrisco ou brita 0; e brita 1, 2, 3, e 4).

A lavra de caulim segue procedimentos similares ao de areia em morros, com uso de desmonte hidráulico. Em algumas minas, o beneficiamento envolve processos químicos com o objetivo de branquear o produto final.

No caso de quartizitos, a lavra é realizada também por desmonte hidráulico, seguido, no caso, de peneiramento.

Em rocha ornamental, a lavra objetiva a retirada de blocos e matacões isolados, sendo efetuada por meio de desmonte com uso de fogacho e corte manual.

A produção média mensal declarada pelos produtores em minas na RMSP é muito variável. No caso de areia, oscila entre 600 e $12.000 \mathrm{~m}^{3} / \mathrm{mês}$; brita, entre 15.000 e 90.000 $\mathrm{m}^{3} / \mathrm{mês}$ (o número mais freqüente é de $30.000 \mathrm{~m}$ 3/mês); argila entre 15 e $500 \mathrm{t} / \mathrm{mês}$; calcário e feldspato com cerca de 500 t/mês; caulim com até 120.000 t/mês; quartzito entre 1.500 e 2.000 t/mês; e rocha ornamental com cerca de $50 \mathrm{~m}^{3} / \mathrm{mês}$ de blocos.

As minas de produção de brita contam, em geral, com um número de funcionários relativamente maior, variando, conforme o porte do empreendimento, entre 15 e 150 pessoas. Nos demais tipos de minas, como na extração de areia, argila ou caulim, a variação é menor, situando-se entre 15 a 30 funcionários.

O preço dos produtos minerais é bastante influenciado pela distância de transporte entre a mina e o local de consumo. Na RMSP, segundo informações do Sindicato das Indústrias de Extração de Areia do Estado de São Paulo- Sindareias, o $\mathrm{m}^{3}$ (cerca de 1,4t) de areia para construção civil, vendido em meados de 1995 (quando $R \$ 1,00$ equivalia a US $\$ 1,00$ ), custava ao consumidor cerca de $R \$ 18,00$ no centro da cidade de São Paulo, $R \$ 15,00$ nos bairros próximos à área central da capital, $\mathrm{R} \$ 12,00$ em bairros mais afastados como Santo Amaro e, para efeito de comparação com a RMSP, entre $R \$ 5,00$ e $R \$ 10,00$ na região do Vale do Paraíba e até $R \$ 2,00$ no Vale do Ribeira. Com isto, o abstecimento de areia na RMSP tem sido relativamente setorizado, visto que, de modo geral, a produção do Vale do Paraíba atende principalmente a zona norte, a da região do município de Mauá e proximidades da rodovia dos Imigrantes serve a zona leste, a dos bairros de Santo Amaro e Parelheiros cobre a zona sul e a dos municípios de Carapicuíba e Barueri a zona oeste. 


\subsubsection{Meio físico e uso do solo}

Estudos de síntese sobre as características do meio físico na RMSP (AB'SABER, 1980; COUTINHO, 1980; CPRM, 1986; RICCOMINI et al., 1992), incluindo os que contemplam os aspectos geotécnicos em face das interações com diferentes formas de uso do solo (IPT, 1985), permitem identificar os principais domínios geológico-geomorfológicos que ocorrem na região e nos quais se desenvolvem as atividades de mineração:

a) rochas cristalinas de idade pré-cambriana (granitos, gnaisses, migmatitos, xistos, quartzitos, entre outros litotipos), associadas às Suites Graníticas, Grupos São Roque e Açungui e Complexos Pilar, Costeiro e Amparo, frequentes em relevo de morros e morrotes, em que predomina a produção de areia, brita e caulim;

b) sedimentos terciário-quaternários de Formações das Bacias de São Paulo e de Taubaté, freqüentes em relevo de colinas, em que predomina a produção de areia; e c) sedimentos aluvionares recentes, distribuídos em planícies e várzeas associadas aos principais cursos d'água da região, como o do rio Tietê, em que predomina a produção de areia e argila.

A partir das informações cartográficas disponíveis sobre características geotécnicas dos terrenos na RMSP (PRANDINI et al. 1992) e de NAKASAWA et al. (1994), pode-se distinguir as principais unidades geotécnicas na RMSP e suas respectivas suscetibilidades aos processos do meio físico induzidos por atividades humanas, entre as quais se inclui a mineração (FIGURA 1.3). A correlação dessas unidades com os principais domínios geológico-geomorfológicos evidencia problemas de erosão e escorregamentos na produção de areia, brita e caulim em morros e morrotes (especialmente nas unidades I, II e III), erosão na de areia em colinas (unidades I e V) e assoreamento e inundação na de areia e argila em planícies aluvionares (unidade VI).

Os solos de alteração (solo saprolítico ou horizonte pedológico C) na RMSP oriundos de rochas cristalinas de idade pré-cambriana, quando expostos à ação das águas pluviais, são, comparativamente, cerca de 6 vezes mais erodíveis do que os níveis correspondentes nos sedimentos terciários (SANTOS, NAKASAWA, 1992). Por isso, potencializam uma produção de sedimentos maior, acarretando riscos acentuados de assoreamento e, conseqüentemente, de inundações (NAKASAWA, HELOU, 1993). 
FIGURA 1.3 - Principais unidades geotécnicas na RMSP - Ver Pasta Desenhos 
A utilização do solo nas áreas ocupadas na RMSP compreende grandes domínios de áreas de uso residencial, concentração industrial, predominância industrial, concentração comercial, uso misto, uso institucional, chácaras de recreio e lazer, parques e reservas estaduais, centros terciários ou de serviços e áreas de corredores (EMPLASA, 1994).

Há diversas modalidades de unidades de conservação ambiental na RMSP, abrangendo espaços remanescentes do ecossistema primitivo (Mata Atlântica) que se encontram protegidos por lei e nos quais, muitas vezes, a atividade mineral se realiza. Além de áreas tombadas pelo Conselho de Defesa do Patrimônio Histórico, Artístico, Arquitetônico e Turístico- Condephaat (Serra do Japi, Serra do Mar, Serra de Boturuna, Nascentes do rio Tietê), há também parques ou reservas estaduais (Cantareira, Juqueri, Jaraguá, Anhanguera, Serra do Mar), reservas florestais ou biológicas, áreas indígenas (Rio Branco, Barragem, Crucutu), estações ecológicas (Itapeti), áreas de proteção ambiental- APA (Mananciais do Vale do Paraíba, Várzea do Tietê, Serra do Mar, Fazenda do Carmo, Cajamar), áreas de interesse especial (Serra do Itapeti, Morro Grande, Serra de Paranapiacaba), áreas sob regulamentação especial (Vale do Botujuru) e áreas de proteção aos mananciais, entre outras (SÃO PAULO, 1988; EMPLASA, 1994).

\subsubsection{Algumas externalidades}

O modo pelo qual o aproveitamento dos recursos minerais vem sendo realizado nas últimas décadas na RMSP, tem gerado um conjunto de efeitos certamente não desejados que, assim entendidos, podem ser denominados de externalidades.

O conceito de externalidade vem recebendo, desde seu surgimento em 1920, com Alfred Marshall (apud COMUNE, 1992), várias contribuições e diferentes denominações: fenômenos externos, efeitos externos, economias ou deseconomias externas, custos externos, entre outros. Diz-se que as externalidades aparecem quando, no funcionamento normal da atividade econômica, ocorrem interdependências "extra-mercado" entre as empresas e os indivíduos (COMUNE, op. cit.). Essa concepção permite considerar a diversidade de conseqüências indesejadas decorrentes de uma dada atividade econômica.

Seguem-se algumas externalidades associadas à mineração, identificadas no contexto atual da RMSP, cuja análise constitui referência na busca de diretrizes para a recuperação ambiental em áreas urbanas (BITAR, 1992; BITAR et al., 1992). Convém salientar que algumas das externalidades apresentadas podem ter sua ocorrência associada à produção mineral em áreas situadas fora da RMSP, uma vez que parte do montante de bens minerais consumidos na metrópole provém de outras localidades próximas, como as regiões do Vale do Paraíba 
(Jacareí, São José dos Campos, Taubaté e outros municípios), Vale do Ribeira (Miracatu, Juquiá e Registro), Sorocaba (Araçriguama), Campinas, Bragança Paulista e Baixada Santista.

\subsubsection{Alterações ambientais e riscos}

As principais alterações ambientais causadas pela mineração na RMSP, particularmente aquelas associadas aos locais em que o empreendimento se encontra instalado, têm sido identificadas por alguns autores (CHIOSSI et al., 1982; MACEDO et al., 1985; TEIXEIRA, 1992), podendo ser resumidas em: supressão de áreas de vegetação; reconfiguração de superfícies topográficas; impacto visual; aceleração de processos erosivos; indução de escorregamentos; modificação de cursos d'água; aumento da turbidez e da quantidade de sólidos em suspensão em corpos d'água receptores; assoreamento e entulhamento de cursos d'água; interceptação do lençol freático com rebaixamento ou elevação do nível de base local; mudanças na dinâmica de movimentação das águas subterrâneas; inundações a jusante; aumento da emissão de gases e partículas em suspensão no ar; aumento de ruídos; lançamento de fragmentos rochosos à distância; sobrepressão do ar; e propagações de vibrações no solo.

Estas alterações, por sua vez, tendem a afetar os diferentes tipos de uso do solo circunvizinhos, muitas vezes gerando situações de risco, com as seguintes conseqüências: danos às fundações de habitações, edificações industriais e comerciais diversas, linhas de transmissão, ruas, estradas e outros usos próximos à mineração; insalubridade e riscos decorrentes do lançamento de resíduos em lagos abandonados e, neste contexto, acidentes de quedas ou afogamento, especialmente com crianças; aumento da vulnerabilidade dos aqüíferos subterrâneos com prejuízos à captação em poços e cacimbas nas proximidades; perda da qualidade das águas situadas a jusante e utilizadas como mananciais para abastecimento público; perda da qualidade do ar; vítimas ou danos decorrentes do ultralançamento de fragmentos rochosos; incômodos às pessoas e danos às habitações e outras edificações causados pela propagação de vibrações no solo e pela sobrepressão atmosférica.

\subsubsection{Conflitos}

O desenvolvimento da atividade mineral no contexto metropolitano tem estabelecido uma série de relações continuadas com outras formas de uso do solo circunvizinhas (habitação, indústria, conservação ambiental, horticultura, lazer, recreação, entre outras). Não raro, essas relações têm ocorrido de maneira conflituosa, notadamente motivadas pela disputa 
cada vez mais acirrada pelo espaço urbano. As situações mais comuns ocorrem pela presença de núcleos habitacionais em locais próximos a minerações (TAVEIRA et al., 1993), incluindo regiões de concentração de chácaras de lazer, bem como pelo desenvolvimento da atividade extrativa em unidades de conservação ambiental e em áreas de várzea onde atividades agrícolas se fazem presentes.

A evolução dos conflitos e a ausência de soluções negociadas, mediadas e institucionalizadas, sobretudo no caso de áreas urbanas, tem levado ora ao cerceamento e fechamento das minerações, ora à manutenção de riscos às populações e usos do solo circunvizinhos (BITAR, 1990). Exemplo disto na RMSP ocorreu em 1986, no caso da pedreira da empresa Firpavi, no km 17 da rodovia Raposo Tavares, município de São Paulo, cujo conflito com a população vizinha levou ao encerramento da atividade mineral.

Por outro lado, a expansão da ocupação urbana tem tornado inviável o aproveitamento de muitas jazidas minerais, especialmente quando os assentamentos se consolidam, impedindo o acesso às matérias-primas potencialmente lavráveis (VALVERDE, KYOTANI, 1986; RUIZ, 1989).

\subsubsection{Depreciação de imóveis circunvizinhos}

Embora a atividade de mineração tenha, implicitamente, um cárater temporário, sobretudo pela perspectiva de esgotamento da jazida, na prática ocorrem situações que tendem a mantê-la durante períodos longos e indefinidos.

Uma das conseqüências deste fato são os baixos valores venais e de mercado atribuídos às propriedades circunvizinhas às minerações na RMSP, especialmente quando comparados aos de imóveis relativamente mais afastados (TEIXEIRA, 1992). Exemplos notáveis ocorrem nas circunvizinhanças de pedreiras, particularmente em face dos incômodos e riscos decorrentes do desmonte rochoso com uso de explosivos, como na zona leste e na região do distrito de Perus, zona norte do município de São Paulo.

\subsubsection{Transtornos ao tráfego urbano}

O transporte da produção mineral gerada na RMSP é feito principalmente por caminhões de alta tonelagem. Geralmente com excesso de carga e, muitas vezes, desprovidos de proteção (por exemplo, cobertura de lona) para os produtos transportados, esses veículos percorrem os caminhos entre a mina e os locais de entrega (empresas de concretagem, depósitos de materiais de construção ou o empreendimento onde o produto será consumido). Nesses percursos, os caminhões se utilizam de vias urbanas comuns, como ruas e avenidas, 
além de vias expressas, como as marginais dos rios Tietê e Pinheiros e os trechos metropolitanos das rodovias que convergem para as áreas centrais da região.

O incremento de tráfego é notável em certos trechos de rodovias que atravessam a RMSP, como na rodovia Presidente Dutra, entre a capital paulista e cidades do Vale do Paraíba ou na rodovia Presidente Castelo Branco que canaliza a produção da região dos municípios de Carapicuíba e Barueri, sobretudo em épocas de demanda elevada de areia para construção. Assim, com a circulação intensa desses veículos, o habitual excesso de carga e a ausência de proteção, tendem a ocorrer significativos danos aos pavimentos asfálticos das vias utilizadas e freqüentes envolvimentos em ocorrências e acidentes de trânsito.

\subsubsection{Geração de áreas degradadas}

A mineração na RMSP tem gerado inúmeras cavas secas ou inundadas, muitas das quais com desníveis ou profundidades que chegam a 30 ou $40 \mathrm{~m}$ e extensões da ordem de centenas de metros, alcançando, em certos casos, alguns quilômetros. Essas cavas, sobretudo aquelas situadas no domínio das planícies aluvionares do rio Tietê, hoje concentradas principalmente nos extremos das regiões leste (Guarulhos, Itaquaquecetuba, Mogi das Cruzes e Biritiba-Mirim) e oeste (Carapicuíba e Barueri), acabam, com o abandono, sendo invadidas pelas águas de superfície e de subsuperfície, exibindo uma sucessão de lagos sem qualquer função urbana e sujeitos à degradação ambiental acelerada em razão do lançamento de resíduos domésticos e industriais.

Do mesmo modo, minerações situadas em terrenos de domínios de rochas cristalinas pré-cambrianas em morros ou morrotes, bem como sedimentos terciário-quaternários em colinas, tendem a gerar áreas sujeitas a processos de degradação intensos e de grande magnitude, como erosão, escorregamentos, assoreamento, entre outros. Tais processos geralmente acabam inviabilizando ou retardando a possível utilização dessas áreas.

\subsubsection{Ocupação desordenada de áreas degradadas}

Apesar da situação de degradação existente em algumas antigas áreas de mineração, há uma crescente tendência no sentido de ocupá-las. Isto tem sido feito geralmente de forma desordenada, irregular e até clandestina, como demonstram os depósitos de lixo e resíduos perigosos, bem como as invasões e habitações de baixa renda instaladas em muitos desses locais, freqüentemente gerando situações de risco.

A falta de áreas disponíveis para a disposição do lixo urbano e industrial, assim como o crescente déficit habitacional na RMSP, tem feito dessas áreas um atrativo. A dimensão atual 
do problema é dada pela estimativa de cerca de 250 áreas degradadas e abandonadas por mineração na RMSP (TEIXEIRA, 1992). Além disto, as cerca de duas centenas de minas ativas continuam a gerar novas áreas degradadas que, com o tempo, poderão ser igualmente abandonadas e submetidas àocupação desordenada.

Por outro lado, a perda do potencial de uso de áreas em virtude da degradação, particularmente onde é crescente o interesse comercial pelos imóveis, como em bairros da zona sul do município de São Paulo, tem gerado um efeito adicional ao uso do solo. Uma vez limitado pelas condições de degradação dos terrenos, como em certas localidades do distrito de Parelheiros, o setor imobiliário tende a elevar os preços dos imóveis não degradados situados em bairros vizinhos, como Campo Limpo, dando-lhes, por comparação, o caráter de "áreas nobres". É o que se verifica, por exemplo, em relação ao bairro do Morumbi, que tem sido "esticado e alargado pelo mercado imobiliário e já engloba grandes regiões das zonas sul e oeste" (AMARAL, 1996).

\subsubsection{Aspectos legais, institucionais e tributários}

A Constituição Federal vigente estabelece que os recursos minerais pertencem à União, a quem cabe a prerrogativa de autorizar e conceder o aproveitamento de jazidas (Artigo 176, caput e parágrafo $1^{\circ}$ ). É competência exclusiva da União legislar sobre "jazidas, minas, outros recursos minerais e metalurgia" (Artigo 22, inciso XII). Aos estados e municípios é permitido apenas, em competência comum com a União, "registrar, acompanhar e fiscalizar as concessões de direitos de pesquisa e exploração de recursos hídricos e minerais em seus territórios" (Artigo 23, item XI).

A legislação mineral brasileira tem sua base no Código de Mineração (Decreto-Lei Federal 227/67), com suas sucessivas alterações e atualizações posteriores, dispondo sobre os regimes de aproveitamento dos recursos minerais encontrados na superfície ou no subsolo nacional. Editado na esfera federal, o Código atribui ao Departamento Nacional da Produção Mineral- DNPM, órgão do Ministério das Minas e Energia- MME, a função de administrar a mineração no território nacional. Os regimes então estabelecidos para o aproveitamento dos recursos minerais no País foram: autorização e concessão; licenciamento; permissão de lavra garimpeira; e monopólio. Aos municípios coube, a partir da Lei Federal 6.567/78, a atribuição de conceder licença específica apenas no caso dos minerais então enquadrados no regime de licenciamento, como os de emprego imediato na construção civil (denominados, segundo o Código, de Classe II), além de argilas para cerâmica vermelha, calcários dolomíticos para corretivo de solo e basalto ornamental. 
Ao Estado tem restado poucas competências, a não ser por convênio com a União ou pelo viés da legislação ambiental (para fins de licenciamento ambiental de empreendimentos, o que envolve diferentes órgãos públicos estaduais e, às vezes, outros federais, como o Instituto Brasileiro do Meio Ambiente e dos Recursos Naturais Renováveis- Ibama). São freqüentes os casos em que o empreendedor atende os procedimentos estabelecidos pela legislação mineral, porém não obtém a licença ambiental, o que gera, muitas vezes, ações e disputas judiciais. Por outro lado, os planos de recuperação têm sido considerados, pelos órgãos ambientais, apenas um instrumento de adequação e controle dos empreendimentos devidamente licenciados.

Por estes e outros aspectos, o modelo centralizado de administração dos recursos minerais no País parece ter se esgotado e tem sido apontado como um entrave na compatibilização entre as atividades de mineração e a conservação ambiental, sobretudo no caso de agregados em meios urbanos (HERMANN, 1992; MARTINS, 1992).

A tentativa de planejar e disciplinar a atividade mineral na RMSP a partir do Plano Diretor de Mineração (SÃO PAULO, 1980), formulado na década 70 através de convênio entre o DNPM e a então Secretaria de Estado dos Negócios Metropolitanos- SNM, teve inúmeros percalços político-administrativos, sendo seguidamente interrompido e poucos os resultados efetivamente alcançados. A mineração continua se desenvolvendo à revelia das diretrizes preconizadas pelo planejamento metropolitano.

Buscando a similaridade com a atuação do Ministério das Minas e Energia- MME, o Estado de São Paulo editou a Lei Estadual 8.275/93, atribuindo à Secretaria de Estado da Energia- SEE a execução da política estadual referente àexploração dos recursos minerais em todo o território paulista, compreendendo a pesquisa, a lavra e o aproveitamento dos recursos minerais (Artigo $2^{\circ}$, caput e item IV). No entanto, a Lei ainda não foi regulamentada e tampouco a SEE dispõe de uma estrutura compatível com a função estabelecida.

Sob o ponto de vista tributário, alguns estudos sobre agregados no Estado de São Paulo (LEMOS et al., 1986; HERMANN, 1992) têm mostrado ser bastante provável a existência de um alto nível de sonegação fiscal, principalmente no setor areeiro. Pronunciamentos públicos de representantes do Sindicato das Indústrias de Extração de Areia do Estado de São Paulo- Sindareias estimam em cerca de 70 a $80 \%$ o nível de sonegação de impostos e contribuições financeiras.

Os problemas decorrentes da centralização legal e os de caráter tributário, aliados ao fato de que a grande maioria das empresas que atuam em regiões urbanas não tem recuperado as áreas por ela degradadas, como preconiza a Constituição Federal vigente, têm tornado a mineração, particularmente sob o ponto de vista da opinião pública, uma atividade de baixo retorno social. Isto, em face da possível retribuição pelo uso de um recurso que constitui, de acordo com a Lei, patrimônio da União, independentemente da inegável importância que os 
minerais explotados na RMSP têm hoje para a economia nacional e para o próprio processo de desenvolvimento e consolidação da metrópole.

\subsubsection{O papel da recuperação de áreas degradadas}

Frente a este panorama de externalidades e problemas, a recuperação de áreas degradadas no contexto metropolitano tenderia a assumir um papel especial, particularmente pela possibilidade de conferir à mineração o desempenho de importante função urbana, qual seja, conter os processos de degradação durante seu funcionamento e compatibilizar 0 encerramento de suas atividades com necessidades públicas ou privadas de uso do solo.

No entanto, apesar de algumas iniciativas importantes desencadeadas nos últimos anos, as medidas de recuperação na RMSP têm sido restritas e ainda predomina a prática do simples abandono de áreas, situação em que, com o tempo, a degradação se acentua e assume intensidades e magnitudes significativas. Além disto, tem sido rara a execução da recuperação por iniciativa e ação das próprias empresas de mineração, sobretudo nos casos de áreas degradadas de grandes dimensões.

Alguns dos mais expressivos exemplos de investimentos aplicados na recuperação de extensas áreas degradadas, a partir de contextos dados em função do abandono dos terrenos durante longo período de tempo, foram patrocinados pelo Poder Público, por razões relacionadas à intenção de tornar viáveis outros projetos. É o que demonstra, entre outros casos, a história da construção do Parque Ecológico do Tietê na cidade de São Paulo, executado a partir de cavas abandonadas por extração de areia para construção civil.

Sobrepõem-se a isso, os modos desordenados pelos quais as áreas degradadas e abandonadas pela mineração têm sido utilizadas na RMSP (deposição clandestina de lixo, bota-foras de sedimentos contaminados dragados de leitos de rios, ocupação de risco, entre outros), que constituem, por si só, evidências de algumas das principais demandas atuais de uso do solo, como aterros sanitários, disposição planejada de resíduos e sedimentos dragados e conjuntos habitacionais.

As soluções de revegetação têm sido predominantemente adotadas em minas médias e grandes situadas em zonas rurais no país, como mostram, entre outros autores, as sínteses de BARTH (1989), GRIFFITH (1992) e MASCHIO et al. (1992). Porém, a recuperação de áreas degradadas no âmbito urbano tende a exigir, desde o seu planejamento, soluções sintonizadas com a destinação futura do local e compatíveis com as demandas de uso do solo das cidades.

No entanto, generalizam-se os casos de minerações na RMSP que têm privilegiado a adoção de medidas restritas de revegetação em suas atividades de recuperação. Além disso, as medidas previstas nos planos de recuperação não têm sido executadas. Não obstante sua 
potencial importância no equacionamento de alguns dos processos de degradação, as medidas de revegetação podem ser insuficientes ou inadequadas em face da diversidade de impactos ambientais gerados.

\subsection{Hipótese de trabalho e objetivo da pesquisa}

Evidencia-se, assim, a hipótese de trabalho que norteou a realização desta pesquisa, ou seja, a observação preliminar de que a maior parte das atividades de recuperação de áreas degradadas por mineração praticadas na RMSP são incipientes e compreendem, essencialmente, medidas restritas de revegetação, cuja finalidade principal é apenas atenuar o impacto visual associado. Além disso, tais medidas não se correlacionam com os usos do solo pós-mineração estabelecidos em planejamento. A verificação desta hipótese constitui o objetivo primordial da pesquisa.

Busca-se investigar diferentes fatores que tendem a influenciar a ocorrência da hipótese, tanto os de âmbito interno à mineração como os externos. Isto inclui a avaliação dos procedimentos técnicos e gerenciais praticados pelas empresas, os aspectos legais, políticos, institucionais e administrativos resultantes da ação do Poder Público e, ainda, a real dinâmica de expansão e adensamento da ocupação urbana em suas relações com as áreas degradadas por mineração. 


\section{CAPÍTULO 2}

\section{MÉTODO DA PESQUISA}

Este Capítulo apresenta o método utilizado na execução da pesquisa, descrevendo as principais etapas realizadas. O método condutor é o da indução, conforme discutido em VARGAS (1985), fundamentado em observações de campo efetuadas em visitas técnicas a áreas de mineração antigas e atuais na RMSP e na coleta de dados e informações nos setores públicos e privados envolvidos na recuperação das áreas degradadas.

O objeto central da pesquisa corresponde às áreas degradadas associadas ao contexto de minas ativas. Complementarmente, outros dois contextos são considerados: minas desativadas e antigas áreas de mineração que atualmente se encontram reabilitadas ou ocupadas por outros usos do solo.

\subsection{Revisão da hipótese}

O início efetivo da pesquisa exigiu a revisão da hipótese de trabalho delineada anteriormente, estabelecendo-se a seguinte descrição acerca das evidências que a fundamentam:

a) a maior parte dos trabalhos de recuperação de áreas degradadas em minas ativas tem caráter incipiente e se baseia principalmente na execução de medidas restritas de revegetação com a finalidade de atenuar apenas o impacto visual;

b) a maior parte dos procedimentos e medidas para a instalação de usos pós-mineração em minas ativas não se correlaciona com os objetivos estabelecidos pelas empresas na documentação técnica relativa ao planejamento da recuperação no empreendimento;

c) o abandono das áreas degradadas, a partir da desativação de minas, tem favorecido a ocupação desordenada; e

d) a maior parte dos projetos de usos pós-mineração executados tem sido patrocinada pelo Poder Público.

Para a verificação da hipótese, efetuou-se uma avaliação das atividades de recuperação a partir do levantamento dos seguintes aspectos básicos: procedimentos de planejamento; medidas praticadas em minas ativas; e a instalação de usos pós-mineração.

Entre os agentes envolvidos na recuperação de áreas degradadas por mineração na RMSP, podem ser distinguidos: empresas de mineração, Poder Público (municipal, estadual e 
federal), empresas privadas de outros segmentos econômicos (indústria, comércio, habitação, entre outros) e comunidade. O conhecimento dos trabalhos realizados por estes setores na recuperação de áreas degradadas, constitui a base para a investigação da hipótese.

Neste contexto, constitui referência também a verificação dos procedimentos relacionados à implementação da recuperação de áreas degradadas por mineração, enquanto instrumento de gestão ambiental, instituído no País como um dos princípios da Política Nacional do Meio Ambiente (Lei 6.938/81 e Decreto 88.351/83). O correlato dessa Política para o caso da mineração, estabelecido na Constituição Federal de 1988 (Artigo 225, parágrafo 2ํㅜ) e posteriormente regulamentado em nível federal (Decreto 97.632/89) com a criação do Plano de Recuperação de Áreas Degradadas- Prad, também representa importante referência para a pesquisa, o mesmo ocorrendo em relação à implementação da Resolução 18/89 da Secretaria de Estado do Meio Ambiente- SMA, que regulamenta o assunto no âmbito do Estado de São Paulo.

\subsection{Pesquisa bibliográfica}

Esta etapa foi dirigida essencialmente para a literatura disponível sobre os variados aspectos envolvidos na recuperação de áreas degradadas por atividades de mineração, particularmente em regiões urbanas, abrangendo análise de conceitos, medidas usualmente empregadas nos trabalhos de recuperação, estratégias de recuperação, métodos e técnicas desenvolvidos, alternativas de uso do solo em antigas áreas de mineração e políticas públicas.

Para orientar a pesquisa bibliográfica, utilizou-se, como ponto de partida, as bases de dados das bibliotecas do Instituto de Pesquisas Tecnológicas do Estado de São Paulo- IPT e da Universidade de São Paulo- USP. A consulta foi desenvolvida especialmente no setor de documentação da Divisão de Geologia- Digeo do IPT e na biblioteca do Departamento de Engenharia de Minas- PMI da Escola Politécnica da USP- Epusp, concentrando-se nos títulos que versam sobre o tema da recuperação de áreas degradadas por mineração em áreas urbanas. A catalogação, citações em texto e listagem das referências bibliográficas, seguiram preferencialmente as especificações da norma NBR-6023 da Associação Brasileira de Normas Técnicas- ABNT, compatibilizada com as diretrizes vigentes na Epusp para apresentação de teses. Os registros e citações sobre leis, decretos, resoluções e outros diplomas legais, contemplam apenas a menção ao número e ano de edição, visto que estes elementos são suficientes para propiciar sua localização em coletâneas referentes àlegislação brasileira, seja em nível federal, estadual ou municipal.

Incluiu-se, nesta etapa, a busca de dados e informações nos acervos de docentes do PMI e de outras institutições, equipes técnicas de órgãos públicos, empresas de mineração e 
empresas de consultoria, além de referências comparativas com casos de outras localidades brasileiras e de outros países, especialmente em metrópoles do terceiro mundo.

\subsection{Levantamentos de campo}

Os levantamentos de campo objetivaram o estudo de áreas degradadas, sendo compostos pelas atividades necessárias à aquisição de dados e informações sobre os procedimentos e medidas de recuperação realizadas em três situações-tipo:

a) minas ativas;

b) minas desativadas; e

c) antigas áreas degradadas por mineração que se encontram atualmente ocupadas ou reabilitadas por outros usos do solo.

Relacionam-se, a seguir, as principais atividades que constituiram esta etapa da pesquisa.

\subsubsection{Critérios para a escolha de áreas}

A escolha das áreas estudadas visou realizar uma amostragem representativa da mineração na metrópole.

O universo inicialmente considerado teve como referência as últimas atualizações oficiais efetuadas sobre a atividade mineral na RMSP (EMPLASA, 1989b), em que constam 463 locais cadastrados, dos quais 183 minas ativas, 50 minas paralisadas (ou desativadas) e 230 abandonadas. Os critérios adotados para a escolha das áreas foram estabelecidos de acordo com as três situações-tipo consideradas.

Em relação æ̀s minas ativas e desativadas, buscou-se manter a proporcionalidade na quantidade de áreas por bem mineral explotado na metrópole, contemplando, assim, o predomínio de areia e brita.

Tanto em minas ativas quanto em inativas, priorizou-se o estudo em minas de médio a grande porte. Para tal, utilizou-se como base os limites gerais de enquadramento definidos na Resolução 26/93 da Secretaria de Estado do Meio Ambiente- SMA, que disciplina os procedimentos de licenciamento ambiental de empreendimentos mineiros em SP. Entre outros critérios, a Resolução considera o porte de um empreendimento segundo a produção média mensal, estabelecendo que pequeno é menor do que $1.000 \mathrm{~m}^{3} / \mathrm{mês}$; médio está entre 1.000 $\mathrm{m}^{3} /$ mês e $5.000 \mathrm{~m}^{3} / \mathrm{mês}$; e grande é maior do que $5.000 \mathrm{~m}^{3} / \mathrm{mês}$. 
A escolha objetivou, ainda, contemplar casos de minas ativas e desativadas que apresentaram Plano de Recuperação de Áreas Degradadas- Prad à SMA, pois, dessa forma, manifestaram formalmente suas intenções em relação ao planejamento das medidas de recuperação e ao uso futuro da área.

Em relação æ̀s antigas áreas de mineração que se encontram atualmente ocupadas, buscou-se contemplar diferentes formas de uso e ocupação do solo instaladas na região, incluindo as que se encontram em desenvolvimento.

\subsubsection{Preparação da ficha de campo}

Para registrar e armazenar os dados e informações obtidos diretamente nos levantamentos de campo nas áreas selecionadas, bem como os adquiridos por meio de entrevistas, bibliografia e Prads, elaborou-se uma Ficha de Dados a ser aplicada individualmente em cada área. Os itens foram organizados segundo cinco grupos básicos: informações gerais; aspectos ambientais e medidas de recuperação; análise do Prad; contexto legal; e informações complementares (ANEXO 1).

Esta atividade precedeu a seleção das áreas a serem estudadas, considerando-se que o tipo de dado ou informação a ser adquirido durante as visitas também poderia auxiliar na sua escolha.

\subsubsection{Escolha das áreas e visitas técnicas}

Com base nos critérios estabelecidos, bem como nos itens que compõem a Ficha de Dados, procedeu-se à escolha das áreas a serem visitadas e estudadas. Durante 0 desenvolvimento da pesquisa, algumas áreas foram excluídas e outras incorporadas ao elenco preliminar.

A aquisição de dados e informações nas áreas selecionadas foi realizada mediante visitas técnicas, por meio de dois procedimentos básicos de campo: formulação de questões aos responsáveis ou encarregados pelas áreas; e observação direta. Ambos foram realizados em minas ativas, minas desativadas e em antigas áreas de mineração, sendo que nesta última situação-tipo envolveu, em alguns casos, particularmente nos locais em que a instalação do uso do solo ocorreu há muitos anos ou até décadas, a coleta de informações com moradores vizinhos ou com profissionais do setor que têm informações históricas sobre as áreas.

As informações de campo foram complementadas por meio de consulta a fontes indiretas, como publicações, Prads e entrevistas com profissionais dos setores envolvidos. 
As visitas de campo foram distribuídas no período de julho de 1994 a junho de 1996, com maior intensidade durante o ano de 1995.

\subsubsection{Amostra obtida}

A amostra resultante das visitas técnicas, apresentando o número total de áreas de mineração estudadas, de acordo com as situações-tipo consideradas e o bem mineral atual ou anteriormente explotado, está na TABELA 2.1.

TABELA 2.1- Número de áreas estudadas, segundo o bem mineral explotado.

\begin{tabular}{llccc}
\hline Bem mineral & Minas ativas & Minas desativadas & $\begin{array}{c}\text { Antigas áreas de } \\
\text { mineração } \\
\text { ocupadas }\end{array}$ & Total \\
\hline Argila & 03 & 02 & 09 & 14 \\
\hline Areia & 15 & 02 & 28 & 45 \\
\hline Brita & 17 & 05 & 14 & 36 \\
\hline Calcário & 01 & - & 02 & 01 \\
\hline Caulim & 04 & 02 & 01 & 08 \\
\hline Filito & - & - & - & 01 \\
\hline Quartzito & 01 & - & - & 01 \\
\hline Rocha ornamental & 01 & - & 54 & 01 \\
\hline & 42 & 11 & 107 \\
\hline
\end{tabular}

Este total constituiu a amostra básica para a aquisição de dados e informações de campo e, por isso, compõe o referencial para a discussão dos resultados e a elaboração de conclusões sobre a hipótese da pesquisa.

O significado da amostra obtida pode ser analisado apenas em relação às minas ativas $\mathrm{e}$ às desativadas ou paralisadas contidas no cadastro de referência (EMPLASA, 1989b). Assim, as 42 minas ativas representam cerca de $23 \%$ dos 183 empreendimentos em atividade e identificados no cadastro. Dentre essas minas ativas, 27 (64\%) apresentaram Prad ao Departamento de Avaliação de Impacto Ambiental- Daia da Secretaria de Estado do Meio Ambiente- SMA. Em relação às minas desativadas, as 11 áreas estudadas correspondem a cerca de $20 \%$ do total de 50 contidas no cadastro da Empresa Metropolitana de Planejamento da Grande São Paulo- Emplasa, sendo que apenas 3 (27\%) apresentaram Prad. 
$\mathrm{Na}$ outra situação-tipo, ou seja, antigas áreas de mineração atualmente ocupadas, a ausência de levantamentos e cadastros anteriores não permite uma aferição comparativa. As 230 áreas abandonadas indicadas no cadastro de referência (EMPLASA, 1989b), não devem ser consideradas para os efeitos de comparação, pois representam apenas um registro parcial e momentâneo em face do processo histórico da mineração na RMSP, em que a sucessão precisa das inúmeras aberturas e fechamentos de minas é praticamente impossível de ser reconstituída.

As áreas estudadas foram lançadas em mapa da RMSP (MAPA 1, anexo), tendo como base apenas alguns dos elementos geográficos principais da metrópole (sede de municípios e principais cursos d'água e reservatórios) e as unidades geotécnicas delimitadas a partir de ampliação e modificação da Carta Geotécnica do Estado de São Paulo (NAKASAWA et al., 1994).

\subsection{Entrevistas}

Os levantamentos e estudos de campo nas áreas selecionadas foram intercalados com entrevistas e contatos com técnicos e profissionais experientes, os quais atuam em instituições ou entidades envolvidas, direta ou indiretamente com a recuperação de áreas degradadas por mineração, como DNPM, Instituto Brasileiro do Meio Ambiente e dos Recursos Naturais Renováveis- Ibama, Secretaria de Estado do Meio Ambiente- SMA (Departamento de Avaliação de Impacto Ambiental- Daia, Departamento de Proteção de Recursos Naturais- DEPRN e Departamento de Uso do Solo Metropolitano- DUSM), Instituto de Pesquisas Tecnológicas do Estado de São Paulo- IPT, Companhia de Tecnologia de Saneamento Ambiental- Cetesb, Emplasa, Prefeitura do Município de São Paulo- PMSP (Secretaria das Administrações Regionais- SAR e Secretaria do Verde e do Meio Ambiente- SVMA) e Sindicato das Indústrias de Extração de Areia no Estado de São Paulo- Sindareias.

Para objetivar a realização e os resultados das entrevistas, elaborou-se uma ficha específica, contendo as questões básicas formuladas (ANEXO 2). Em alguns casos, as entrevistas foram gravadas em som e imagem.

A relação nominal dos profissionais entrevistados, bem como de outros contatados e que forneceram informações específicas sobre localização e histórico de áreas recuperadas, encontra-se no ANEXO 3. As questões formuladas nas entrevistas contemplam os procedimentos adotados pelas instituições e entidades, particularmente no sentido de obter informações gerais e verificar os resultados efetivamente alcançados na recuperação de áreas degradadas por mineração. 
A realização das entrevistas ocorreu no período de julho de 1994 a dezembro de 1996, a maior parte das quais intercaladamente às visitas técnicas de campo, procedimento que também auxiliou na escolha e definição das áreas estudadas.

\subsection{Análise dos planos de recuperação}

Foram levantados os dados gerais relativos a 102 Planos de Recuperação de Áreas Degradadas- Prads de minas ativas e desativadas na RMSP, obtidos em listagem atualizada até junho de 1995 do acervo do Departamento de Avaliação de Impacto Ambiental- Daia/SMA.

Dentre estes planos, foram localizados e consultados 91 Prads. Os documentos foram examinados sobretudo quanto às alternativas de uso do solo previstas no processo de reabilitação das áreas degradadas e, ainda, no que se refere æ̀s medidas de recuperação propostas pelas empresas, independentemente de vinculação com o uso pós-mineração previsto, cronograma, prazos, custos e participação da comunidade.

\subsection{Integração e análise dos resultados}

Nesta etapa foram analisados e integrados os resultados obtidos nas várias atividades que compõem a pesquisa, delineadas as conclusões preliminares sobre as áreas estudadas, estabelecidas as generalizações para os demais casos na RMSP e procedidas as verificações finais.

Os resultados foram organizados em quatro partes principais. A primeira corresponde à síntese obtida a partir da revisão bibliográfica (Capítulo 3). A segunda, fundamenta-se na análise dos Prads e nas visitas técnicas às minas ativas, contemplando os resultados da avaliação sobre os procedimentos relacionados ao planejamento da recuperação realizado pelas empresas (Capítulo 4). A terceira considera os resultados da identificação e avaliação das medidas praticadas em minas ativas, particularmente quanto ao grau de difusão e aplicação, finalidades, procedimentos usuais e desempenho (Capítulo 5). A quarta parte contém os resultados da avaliação sobre o processo de reabilitação de antigas áreas de mineração e a instalação de usos pós-mineração (Capítulo 6).

\subsection{Elaboração das conclusões gerais}

Nesta etapa foram sintetizadas as conclusões gerais da pesquisa, particularmente sobre os procedimentos técnicos e gerenciais utilizados na recuperação em minas ativas e sobre as 
atividades relacionadas ao processo de reabilitação de áreas degradadas por mineração na RMSP (Capítulo 7).

O tipo de conclusão esperado é o de afirmação ou negação da hipótese da pesquisa em face de suas evidências apontadas, ou seja, de que a maior parte das minas ativas na RMSP pratica medidas incipientes de recuperação com a finalidade de atenuar apenas o impacto visual; as atividades praticadas pelas empresas de mineração para a instalação de usos pósmineração não se correlacionam com o planejamento realizado; as áreas abandonadas favorecem a ocupação desordenada; e a maioria dos projetos de reabilitação é patrocinada pelo Poder Público.

No caso positivo, confirmar-se-á a hipótese da pesquisa e, em caso negativo, sua contradição. Em qualquer das possibilidades, inclui-se a apresentação de recomendações aos setores públicos e privados envolvidos na questão, particularmente quanto ao aprimoramento da recuperação de áreas degradadas por mineração como instrumento de planejamento e gestão ambiental da RMSP e de outras áreas urbanas e metropolitanas do Brasil e de países em desenvolvimento e, ainda, no que se refere à difusão técnica de procedimentos e medidas de recuperação. 


\section{CAPÍTULO 3}

\section{PANORAMA DA RECUPERAÇÃo DE ÁREAS DEGRADADAS POR MINERAÇÃo}

Este Capítulo apresenta um breve panorama mundial e nacional sobre diferentes aspectos relacionados à recuperação de áreas degradadas por mineração. Baseia-se na revisão bibliográfica efetuada e compreende conceitos básicos, procedimentos usuais, métodos e técnicas de recuperação, usos pós-mineração e os principais instrumentos legais e institucionais utilizados.

\subsection{Conceitos básicos}

O levantamento e análise dos vários aspectos envolvidos na recuperação de áreas degradadas por mineração exige reflexão inicial sobre algumas noções básicas, em especial os conceitos de degradação e de recuperação.

\subsubsection{Degradação}

O conceito de degradação tem sido geralmente associado aos efeitos ambientais considerados negativos ou adversos e que decorrem principalmente de atividades ou intervenções humanas. Raramente o termo se aplica às alterações decorrentes de fenômenos ou processos naturais. O conceito tem variado segundo a atividade em que esses efeitos são gerados, bem como em função do campo do conhecimento humano em que são identificados e avaliados.

A abordagem biológica comumente trata de aspectos relacionados à evolução de ecossistemas, como em CAIRNS JR. (1986), que considera o conceito de perturbação ou distúrbio ("disturbance") como alteração resultante de atividades humanas e que não pode ser corrigida rapidamente, citando três situações influenciadas pelo caráter temporal: os distúrbios súbitos e inesperados, como os decorrentes de acidentes ou falhas de origem tecnológica em processos industriais; os distúrbios que ocorrem durante período de tempo significativo, mesmo que tenham sido detectados apenas recentemente, como os derivados de descargas de efluentes industriais; e os distúrbios planejados, como os da mineração em superfície.

Terminologia semelhante é adotada no campo geomorfológico e do paisagismo, como em TOY, HADLEY (1987) que também consideram o conceito de perturbação ou distúrbio, porém numa perspectiva espacial ("Iand disturbance"), correlacionando-o com os efeitos 
geomórficos produzidos na paisagem por diferentes atividades humanas como mineração em superfície, urbanização, pastagem, agricultura, usos recreativos e construção civil. Reconhecem que muitos desses distúrbios têm importância menor ou são transitórios e que a paisagem pré-existente pode ser recuperada para uma forma aceitável de produtividade e em conformidade com um plano de uso prévio.

Especialmente dedicado à mineração, o trabalho de WILLIANS et al. (1990), divulgado pelo Instituto Brasileiro do Meio Ambiente e dos Recursos Naturais Renováveis- Ibama, admite um conceito relacionado aos aspectos biológicos, edafológicos e hídricos afetados pela atividade extrativa, considerando que "a degradação de uma área ocorre quando a vegetação nativa e a fauna forem destruídas, removidas ou expulsas; a camada fértil do solo for perdida, removida ou enterrada; e a qualidade e regime de vazão do sistema hídrico for alterado" (WILLIANS et al., op.cit., p.13). Em seguida, estabelecem o conceito de degradação ambiental, que "ocorre quando há perda de adaptação às características físicas, químicas e biológicas e é inviabilizado o desenvolvimento socioeconômico". Aparentemente, a perda de adaptação a que se referem os autores, diz respeito ao solo, sugerindo, então, que a degradação do solo conduz àdegradação ambiental (WILLIANS et al., op. cit., p.13).

Por sua vez, MASCHIO et al. (1992) retomam o conceito de perturbação, discutindo a noção de desgaste parcial ou total de ecossistemas climáxicos locais e a sua possível reversibilidade, em que a irreversibilidade indica tempo e/ou investimentos inviáveis em termos práticos. Em seqüência gradativa e crescente, os autores consideram os seguintes conceitos: perturbação, quando o desgate é parcial e reversível; descaracterização, quando o desgaste é total e reversível; depauperação, quando o desgaste é parcial e irreversível; e, enfim, degradação, quando o desgate é total e irreversível, ocorrendo a destruição do ecossistema.

Fundamentados em observações no campo agronômico, LAL et al. (1989) diferenciam processos e fatores de degradação do solo, em que os primeiros correspondem às ações e interações químicas, físicas e biológicas que afetam a capacidade de auto-regulação do solo ("soil") e sua produtividade; e os segundos compreendem os agentes e catalizadores naturais ou induzidos pelo homem, que colocam em movimento os processos e causam alterações nas propriedades do solo e nos seus atributos de sustentação da vida. Entre os processos de degradação do solo induzidos pelo homem citam a compactação, erosão acelerada, desertificação, salinização e lixiviação e acidificação. Entre os fatores, mencionam a agricultura, indústria e urbanização. Citam que as alterações produzidas pelos processos geram, entre outros aspectos, efeitos negativos sobre a qualidade ambiental, estabelecendo, então, a relação com o conceito de solo enquanto espaço geográfico ("land”) e, assim, o sentido amplo de degradação do solo ("land degradation"). 
Dessa forma, a degradação do solo pode ser vista como resultado de processos ambientais que causam a perda de produtividade ou o declínio da qualidade ambiental (SÁNCHEZ, 1992a). Exemplifica-se com o caso da agricultura, em que ocorre a redução do rendimento de colheitas e de atributos estéticos.

No quadro da normalização técnica brasileira a degradação do solo é apontada pela NBR 10703 como a "alteração adversa das características do solo em relação aos seus diversos usos possíveis, tanto os estabelecidos em planejamento quanto os potenciais" (ABNT, 1989 , p.16). O conceito contempla o entendimento de solo enquanto espaço geográfico, ou seja, extrapola o sentido de matéria ou componente predominantemente abiótico do ambiente. Além disto, ao citar a expressão "alteração adversa", sugere a aproximação com o conceito de efeito ou impacto ambiental considerado negativo. Todavia, em outra norma, a NBR 13030, específica para mineração, definem-se áreas degradadas como "áreas com diversos graus de alteração dos fatores bióticos e abióticos, causados pelas atividades de mineração", mantendo a noção de alteração, porém sem vinculação com o uso do solo (ABNT, 1993, p.56)

As referências técnicas contidas na legislação ambiental brasileira não são claras e geralmente confundem os conceitos de poluição, degradação ambiental e impacto ambiental. Até meados da década de 80 , o conceito de degradação ambiental no Brasil era dado pelo termo poluição (introduzido em SP pela Lei Estadual 997/76), às vezes com o emprego subsidiário de termos como devastação no caso de supressão de extensas áreas de cobertura vegetal nativa (SÁNCHEZ, 1994). O Artigo $2^{-}$da Lei Estadual 997/76 traduz poluição essencialmente como a introdução de matéria ou energia no ambiente, em condições que possam afetar negativamente o homem ou outros organismos. Por sua vez, a Política Nacional do Meio Ambiente (Lei Federal 6938/81) expressa poluição como "degradação da qualidade ambiental..." (Artigo $3^{\circ}$, inciso III). Sobrepõe-se a isto, o conceito oficial de impacto ambiental contido na Resolução 01/86 do Conselho Nacional do Meio Ambiente- Conama, com uma definição similar ao de poluição da Lei Federal 6938/81.

As normas legais mais elucidativas e abrangentes expressam o conceito de degradação da qualidade ambiental como a "alteração adversa das características do meio ambiente" (Artigo $3^{\circ}$, inciso II da Lei Federal 6.938/81) e, no caso da mineração, a degradação como os "processos resultantes de danos ao meio ambiente, pelos quais se perdem ou se reduzem algumas de suas propriedades, tais como a qualidade ou capacidade produtiva dos recursos ambientais" (Decreto Federal 97.632/89, que estabelece a exigência de Plano de Recuperação de Áreas Degradadas- Prad, para as atividades de mineração). A combinação destes conceitos é muito próxima àdefinição de degradação do solo contida em ABNT (1989).

No campo do urbanismo e do conhecimento voltado para a questão ambiental das cidades e do ambiente construído, contexto em que uma ampla diversidade de atividades e 
interações humanas se desenvolve, o conceito de degradação está geralmente associado à perda da função urbana das formas de uso do solo existentes nas áreas consideradas, tanto em relação às condições preexistentes quanto às previstas ou estabelecidas em diretrizes de planejamento.

Enfim, embora controverso e não consensual, o conceito de degradação parece estar sempre associado à noção de alteração ambiental gerada por atividades humanas e considerada adversa, o que, no contexto urbano, tende a incluir os efeitos negativos ao uso do solo em face de sua função efetiva, planejada ou potencial.

\subsubsection{Recuperação}

Sobre este termo, a literatura técnica é relativamente vasta e podem ser encontradas referências nas diferentes áreas do conhecimento que, de algum modo, tendem a contribuir nos trabalhos de recuperação de áreas degradadas. A diversidade de abordagens é notável quando se mencionam conceitos segundo diferentes autores (IBRAHIM, 1996).

Observa-se que o conceito de recuperação tem sido geralmente apresentado e discutido não apenas sob os aspectos que caracterizam sua execução, mas principalmente em função dos seus objetivos e metas.

DOWN, STOCKS (1977) consideram o termo restauração ("restoration") apropriado ao contexto da mineração, compreendendo as atividades que visam recriar a topografia original e restabelecer as condições prévias de uso do solo, sendo que qualquer outra alternativa corresponderia à recuperação ("reclamation").

A impossibilidade de retorno da superfície minerada à situação original é admitida por CAIRNS JR. (1986), considerando as seguintes opções a partir de um ecossistema degradado e segundo o grau de recuperação desejado: restauração, representando uma situação relativamente próxima das condições iniciais do ecossistema, porém em um grau intermediário; reabilitação ("rehabilitation"), representando o alcance de algumas das condições iniciais e em um grau superior à restauração; e o desenvolvimento de ecossistemas alternativos, representando condições bastante diferentes do ecossistema original, porém no mesmo grau da restauração. Usa também os termos reparação ("recovery"), recuperação e regeneração ("regeneration"), admitindo que embora a opção de abandono ("neglect") da área degradada possa tender, com o tempo, à estabilização, ocorrerá em condições muito distantes da original e em um grau muito inferior às demais possibilidades.

A normalização técnica brasileira sintetizou diversos conceitos presentes na literatura nacional e internacional até meados da década de 80 e, apoiada em BOX (1978), estabeleceu a seguinte distinção: restauração do solo, em que são reproduzidas as condições existentes na 
área antes de sua perturbação, salientando que a completa restauração é rara ou até impossível; recuperação do solo, como "processo de manejo do solo no qual são criadas as condições para que uma área perturbada, ou mesmo natural, seja adequada a novos usos" (ABNT, 1989, p.34), devolvendo o equilíbrio dos processos ambientais atuantes anteriormente. Deve-se observar que o conceito de manejo vigente na época, embora geralmente restrito a aspectos ecológicos ou florestais, mostra uma correspondência com o conceito moderno de gestão ou gerenciamento; e reabilitação do solo, como "forma de recuperação do solo em que uma área perturbada é adequada a um uso determinado, segundo um projeto prévio" (ABNT, op.cit., p.34). Admite-se que esses usos podem ser comercial, industrial, habitacional, agrícola, conservação ambiental, recreativo, lazer, cultural, entre outros.

Por outro lado, a norma técnica NBR 13030, específica sobre mineração e editada no início dos anos 90, contempla exclusivamente o conceito de reabilitação, definindo-o como o "conjunto de procedimentos através do qual se minimizam os impactos bióticos e abióticos causados pelas atividades de mineração, de acordo com planejamento preestabelecido" (ABNT, 1993, p.56).

A aplicação dos conceitos da ABNT para a maioria dos casos de mineração permite considerar que a possibilidade de restauração é, de fato, bastante improvável, senão impossível. Isto principalmente em razão dos grandes volumes de materiais escavados e transferidos para outros locais durante as atividades de mineração. No caso de agregados, como areia, rocha para brita e outros materiais comumente explotados em regiões urbanas, os volumes não aproveitados são insuficientes para a completa restauração das áreas degradadas, particularmente quanto à recomposição da paisagem, induzindo à recuperação propriamente dita (no sentido da estabilização das áreas degradadas) ou à reabilitação (no sentido de conferir outro uso para as áreas degradadas). Assim, como sugere a última norma da ABNT sobre o assunto, o conceito de reabilitação se destaca no caso de mineração de agregados em face de sua especial adequação às situações urbanas.

Convém desfazer eventual noção de recuperação como um evento que ocorre em uma época ou prazo determinado, devendo sempre ser considerada como um processo de planejamento contínuo que se inicia antes da mineração e termina muito depois do encerramento da atividade extrativa (BARTH, 1989).

A legislação federal brasileira menciona que o objetivo da recuperação é o "retorno do sítio degradado a uma forma de utilização, de acordo com um plano preestabelecido para o uso do solo, visando a obtenção de uma estabilidade do meio ambiente" (Decreto Federal 97.632/89), o que incorpora o conceito de reabilitação ao de recuperação contidos na NBR 10703 (ABNT, 1993), este último mais abrangente e, talvez por isso, mais usualmente 
empregado. Além disso, expressa seu objetivo primordial, ou seja, a perspectiva de atingir a estabilidade do ambiente.

Abordagem similar à da legislação brasileira é apresentada no manual de WILLIANS et al. (1990) sobre técnicas de revegetação aplicáveis àmineração, em que "recuperação significa que o sítio degradado será retornado a uma forma e utilização de acordo com um plano preestabelecido para o uso do solo. Implica que uma condição estável será obtida em conformidade com os valores ambientais, estéticos e sociais da circunvizinhança" (WILLIANS et al., 1990, p. 13). Afirmam que a restauração é quase impossível no caso da mineração e, embora considerem adequado o conceito de reabilitação, preferem utilizar recuperação em virtude de sua fácil compreensão pelo público.

Não obstante, o termo restauração é comumente encontrado na literatura técnica internacional sobre remediação de áreas contaminadas por resíduos ou rejeitos (inclusive de mineração), para designar o resultado final de medidas de tratamento dos solos ou águas superficiais e subterrâneas afetados. O uso do termo remediação ("remediation") é empregado em razão do caráter predominantemente químico do tratamento utilizado (ESTADOS UNIDOS DA AMÉRICA, 1990).

Análise de resultados em projetos de recuperação iniciados e executados há muitos anos em minerações de outros países, permite identificar alguns aspectos fundamentais em relação ao uso do solo. Para serem bem sucedidos, os trabalhos de reabilitação normalmente consideram o ambiente natural e cultural da região e o uso do solo pós-mineração deve ser gerenciável e sustentável (DIETRICH, 1990).

A reabilitação como um processo pelo qual os impactos ambientais da mineração são reparados, é considerada por órgãos de controle ambiental de outros países, como a agência de proteção ambiental da Austrália, distinguindo-se quatro categorias diferentes de acordo com os objetivos de longo prazo: restauração das condições primitivas de ecossistemas preexistentes à mineração; recuperação das condições de uso de solo preexistentes à mineração; desenvolvimento de um projeto de uso do solo significativamente diferente do preexistente àmineração; e transformação de áreas pouco produtivas ou mal conservadas em áreas com condições seguras e estáveis. O processo de reabilitação normalmente compreende dois estágios: o desenho ou configuração da paisagem com a reconstrução de uma superfície estável do solo; e a revegetação ou desenvolvimento de uma alternativa de uso do solo sobre a paisagem reconstruída (AUSTRÁLIA, 1995).

No Brasil, observa-se que há um entendimento bastante generalizado de que recuperar uma área significa encontrar um outro uso produtivo para ela, que pode ser igual ou diferente do uso pré-mineração, devendo apresentar um equilíbrio dinâmico com a circunvizinhança (SÁNCHEZ, 1995). Enfatiza-se que esse equilíbrio é geralmente interpretado com base em três 
critérios: físico, químico e biológico, sendo que este último se aplica mais às áreas rurais ou florestais e que no contexto urbano prevalecem os dois primeiros. Sugere-se, então, o critério de equilíbrio com o tecido urbano, para o qual os projetos de recuperação devem contemplar a consulta e a participação da comunidade.

No campo do urbanismo, os conceitos usualmente aplicados à questão ambiental das cidades, particularmente no que se refere à correção dos problemas existentes em áreas degradadas, contemplam uma vasta diversidade de termos como recuperação, renovação, reabilitação, reestruturação, remodelamento e revitalização (ALMEIDA, BRUNA, 1996). Todos estes termos têm sido utilizados no sentido de caracterizar projetos ou ações que visam estabelecer algum tipo de uso do solo nas áreas degradadas, seja preexistente ou novo, em conformidade com as condições ambientais e culturais da circunvizinhança e com as diretrizes preconizadas na legislação de uso do solo urbano. Contudo, também é predominante a utilização do termo recuperação, englobando os demais conceitos.

\subsubsection{Integração e evolução dos conceitos}

Os conceitos de degradação e recuperação geralmente são considerados de modo integrado. A perspectiva de classificação das condições de um ecossistema em face das reflexões sobre desenvolvimento sustentável, segundo abordagem da União Internacional para a Conservação da Natureza- UICN, Programa das Nações Unidas para o Meio AmbientePNUMA e Fundo Mundial para a Natureza- WWF (UICN, 1991), traz uma análise conceitual ampla, identificando primeiramente os sistemas naturais como os "ecossistemas onde, desde a Revolução Industrial (1750), o impacto do homem (a) não foi maior do que o de quaisquer outras espécies nativas, e (b) não afetou a estrutura do ecossistema. A mudança climática está excluída da definição, porque a mudança climática causada pelo homem deve afetar todos os ecossistemas e eliminar todos os ecossistemas naturais como definidos aqui" (UICN, op.cit., p.35).

A partir daí, a abordagem da UICN define, em seqüência, os sistemas modificados, sistemas cultivados, sistemas construídos e sistemas degradados, estes últimos como os "ecossistemas cuja diversidade, produtividade e condição para habitação foram enormemente reduzidas. A degradação dos ecossistemas da terra é caracterizada por perda de vegetação e de solo; e a dos ecossistemas aquáticos é frequentemente caracterizada por águas poluídas que podem ser toleradas por poucas espécies" (UICN, 1991, p.35). Assim, de acordo com este conceito, os sistemas degradados são considerados insustentáveis, sendo que somente a sua recuperação ou reabilitação permitiria levá-los à condição de potencialmente sustentáveis, situando-se, em seqüência invertida, nas categorias de sistemas construídos, cultivados ou 
modificados. Negligenciar ou abandonar a área pode levar tanto àrecuperação espontânea do ambiente quanto à continuidade e intensificação do processo de degradação. Ao considerar a associação em relação ao futuro, a abordagem incorpora o conceito de sustentabilidade ambiental àquestão da recuperação de áreas degradadas.

Breve análise comparativa entre diferentes abordagens de recuperação e de suas aplicações às áreas degradadas por mineração, permite identificar uma evolução do conceito ao longo das últimas décadas. De maneira geral, observa-se uma passagem do objetivo amplamente difundido de procurar restabelecer as condições originais do sítio degradado, para a busca de situações em que a estabilidade do ambiente e a sua sustentabilidade sejam garantidas. Além disto, é notável a crescente abordagem de recuperação como um processo que deve ser realizado mediante um plano previamente elaborado e com objetivos bem estabelecidos e explicitados (TABELA 3.1).

TABELA 3.1- Sintese comparativa do conceito de recuperação aplicado à mineração, segundo diferentes autores.

\begin{tabular}{|c|c|}
\hline Autor & Conceito de recuperação \\
\hline DOWN, STOCKS (1977) & $\begin{array}{l}\text { qualquer alternativa, exceto recriação da topografia original e restabelecimento das condições } \\
\text { prévias de uso do solo (que consideram restauração); }\end{array}$ \\
\hline CAIRNS JR. (1986) & retorno parcial ou total da superfície às condições iniciais; \\
\hline TOY, HADLEY (1987) & obtenção de uma forma aceitável de produtividade e em conformidade com um plano de uso prévio; \\
\hline ABNT (1989) & processo em que se criam as condições de adequação a um novo uso e de ambiente estável; \\
\hline BARTH (1989) & processo planejado de uso do solo; \\
\hline Lei Federal do Prad (1989) & retorno do sítio a uma forma de uso, visando a estabilidade ambiental; \\
\hline WILLIANS et al. (1990) & retorno do sítio a um uso de acordo com plano prévio e em conformidade com a circunvizinhança; \\
\hline DIETRICH (1990) & $\begin{array}{l}\text { processo que deve considerar o ambiente natural e cultural da região circunvizinha e obter um uso } \\
\text { do solo gerenciável e sustentável; }\end{array}$ \\
\hline UICN (1991) & retorno do sistema a uma condição sustentável ou potencialmente sustentável; \\
\hline MASCHIO et al. (1992) & processo em que se busca a reversibilidade do desgaste parcial ou total de ecossistemas; \\
\hline ABNT (1993) & procedimentos de minimização dos impactos ambientais de acordo com plano prévio; \\
\hline AUSTRÁLIA (1995) & $\begin{array}{l}\text { processo de reparação dos impactos ambientais, com reconstrução de uma superfície estável do } \\
\text { solo e revegetação ou instalação de outro uso do solo; }\end{array}$ \\
\hline ALMEIDA, BRUNA (1996) & $\begin{array}{l}\text { estabelecimento de um uso do solo compatível com o ambiente circunvizinho e com as diretrizes de } \\
\text { planejamento. }\end{array}$ \\
\hline
\end{tabular}


Buscando-se um entendimento apropriado ao contexto metropolitano, o conceito de recuperação deve contemplar, ainda, uma abordagem compatível com o desenvolvimento da mineração em meio aos riscos de degradação urbana acelerada a que estão sujeitas as áreas abandonadas. Isto, especialmente em razão da intensidade e velocidade do processo de uso e ocupação do solo verificado nas médias e grandes cidades.

Dessa forma, a recuperação de áreas degradadas por mineração em regiões urbanas, como na RMSP, pode ser considerada como um processo que deve compreender os procedimentos e medidas necessários à rápida estabilização do ambiente e à progressiva instalação de um uso do solo previamente planejado. O objetivo primordial deve ser a estabilidade ou equilíbrio da área em relação ao meio circunvizinho. Para isso, o uso pósmineração proposto deve estar em conformidade com as condições ambientais e culturais da circunvizinhança e, ainda, ser produtivo, gerenciável e potencialmente sustentável. Implicitamente, em termos temporais, a estabilização em meio urbano ou metropolitano se constitui como um objetivo a ser alcançado preferencialmente a curto prazo, enquanto a instalação do uso do solo pressupõe uma perspectiva de resultados a serem obtidos a médio e longo prazos.

\subsection{Atividades de recuperação}

Assim como em qualquer outra temática relacionada à busca de soluções para problemas urbanos e ambientais, a recuperação de áreas degradadas tem envolvido abordagens interdisciplinares, reunindo e integrando o conhecimento de diferentes campos do conhecimento humano (administração, agronomia, arquitetura, biologia, economia, engenharia, hidrologia, geografia, geologia, medicina, química, sociologia, entre outros). Variando conforme a situação, as abordagens interdisciplinares têm, na prática, evoluído para a transdisciplinariedade e tendem a oferecer soluções mais completas para os problemas, podendo contribuir para um melhor desempenho e eficácia dos trabalhos de recuperação.

Os procedimentos e atividades que envolvem a recuperação de áreas degradadas por mineração têm variado de acordo com cada caso ou experiência realizada. Porém, de uma maneira geral, a partir da identificação e avaliação preliminar de uma área degradada (incluindo eventuais medidas emergenciais necessárias), compreende basicamente 0 planejamento da recuperação (incluindo, se necessário, uma avaliação mais detalhada e completa da degradação), execução do plano de recuperação elaborado e a realização do monitoramento e manutenção das medidas implementadas.

\subsubsection{Avaliação de áreas degradadas}


Em qualquer trabalho de recuperação, a primeira atividade compreende a identificação e caracterização dos processos de degradação atuantes e a análise de suas conseqüências ambientais. Para isto, é necessário o uso de indicadores (MUNN, 1975) que traduzam quantitativa ou qualitativamente o grau da degradação existente e, ainda, permitam estimar a dimensão dos esforços técnicos e econômicos que deverão ser alocados na recuperação. A avaliação deve contemplar, entre outros aspectos, a análise dos riscos à saúde e segurança das comunidades eventualmente afetadas, bem como aos usos do solo circunvizinhos. A consulta a essas comunidades é fundamental nesta atividade, de modo a obter informações importantes para uma avaliação completa da degradação e seu histórico.

Algumas das principais determinações que devem ser feitas nesta atividade são apontadas por CAIRNS JR. (1986), particularmente no caso de avaliação da degradação em ecossistemas: o grau da alteração, a extensão da área na qual a alteração está ocorrendo e o significado ecológico da degradação, inclusive nos ecossistemas vizinhos.

BITAR et al. (1993a) relacionam alguns indicadores e parâmetros geológico-geotécnicos freqüentes na avaliação de áreas degradadas por mineração e outras atividades no meio urbano: feições erosivas de pequeno porte, feições erosivas de grande porte, feições de massas movimentadas, feições de massas em movimentação, posicionamento dos níveis freáticos, dimensão do assoreamento, alcance da poluição do solo, evidências de colmatação do solo, grau de compactação do solo, grau de umidade do solo. Dependendo de cada situação e do tipo de área degradada, outros indicadores ambientais devem ser utilizados.

A norma NBR 12649 que trata da "Caracterização de cargas poluidoras na mineração" (ABNT, 1993), aponta diversos indicadores e parâmetros de qualidade da água que podem ser utilizados na atividade mineral. Aborda, entre outros bens minerais, os casos específicos da areia, argila, calcário e caulim, freqüentes na RMSP, apresentando recomendação para que sejam consultadas também a NBR 9897 ("Planejamento de amostragem de efluentes líquidos e corpos receptores- Procedimento") e a NBR 9898 ("Preservação e técnicas de amostragem de efluentes líquidos e corpos receptores- Procedimento").

Avaliação da degradação em lagos remanescentes de mineração de areia em planície aluvionar, como no rio Paraíba do Sul, em Jacareí, SP, considera indicadores de qualidade da água, como transparência $(\mathrm{cm})$, turbidez $(\mathrm{mg} / \mathrm{l}), \mathrm{pH}$, oxigênio dissolvido- OD (mg/l), demanda bioquímica de oxigênio- DBO (mg/l), entre outros. Indicadores e parâmetros do meio biótico também são incluídos, como a densidade relativa às comunidades zooplanctônica e bentônica existentes no lago, determinada pelo $\mathrm{n}^{\circ}$ de indivíduos $/ \mathrm{l}$ e pelo $\mathrm{n}^{\circ}$ de indivíduos $/ \mathrm{m}^{2}$, respectivamente (SHIMIZU et al., 1995).

Sobre os métodos mais apropriados à realização de uma avaliação preliminar de campo ("field screening"), no caso de áreas contaminadas por resíduos ou rejeitos perigosos, tem sido 
proposto o uso de técnicas de execução rápida e de baixo custo, suficientes para determinar apenas se certos contaminantes estão presentes ou ausentes e se estão dentro ou fora dos padrões preestabelecidos (COMPTON, 1992). Para a delimitação detalhada da extensão da contaminação, a abordagem tende a ser similar à dos métodos de prospecção e pesquisa mineral, comparando-se o solo contaminado com o corpo de uma jazida (MARKER et al. 1993).

No caso de mineração de agregados em regiões urbanas, uma avaliação preliminar e expedita das áreas degradadas pode ser suficiente para obter uma estimativa da ordem de grandeza dos trabalhos e custos de recuperação, como se verifica em estudo realizado em área abandonada por mineração de areia em planície aluvial e em encosta de morro no município de Embu, RMSP (VASCONCELOS et al., 1996). Neste caso, realizado no prazo de uma semana por quatro profissionais especializados, obteve-se a dimensão das medidas que devem ser executadas e uma estimativa dos recursos financeiros necessários à estabilização dos processos do meio físico.

Enfim, pode-se considerar que a avaliação inicial deve identificar, essencialmente, os processos de degradação instalados e os impactos ambientais decorrentes. Dependendo do grau ou estágio atingido pela degradação e da magnitude dos impactos, medidas imediatas e urgentes podem ser necessárias, tais como o isolamento da área degradada, a remoção das comunidades eventualmente ameaçadas, a instalação de um sistema de sinalização e alerta na área, entre outros.

\subsubsection{Planejamento da recuperação}

As atividades básicas no planejamento da recuperação geralmente incluem a definição dos objetivos, o estabelecimento do uso futuro da área e a elaboração de um plano de recuperação (WILLIANS et al., 1990). Tais atividades se assemelham às propostas por BARTH (1989) para o processo de recuperação por meio de revegetação das áreas degradadas, porém precedidas de uma etapa inicial e imprescindível em que o compromisso do empreendedor deve ser estabelecido (BAUER, 1989a).

A tomada de decisão sobre o uso futuro da área deve levar em conta a relevância técnica, social e legal das alternativas propostas, bem como os custos e prazos envolvidos na sua implementação (CAIRNS JR., 1986). O planejamento da recuperação no caso de agregados deve considerar, ainda, os planos de desenvolvimento da região ou município em que a atividade mineral se localiza (MARTINS, 1995).

Estudos desenvolvidos em vários países revelam que os custos das medidas de recuperação são sensivelmente reduzidos quando, desde o início da lavra, estabelece-se um projeto de recuperação da área, em que alguns aspectos operacionais influentes podem ser 
ressaltados: remoção e armazenamento da cobertura vegetal e da camada superficial do solo; aterros, material de empréstimo, contenção de taludes, aplainamentos e acabamento final das frentes de lavra; reposição da camada de solo fértil e revegetação (SÃO PAULO, 1982).

Efeito semelhante tende a ocorrer na fase de desativação ou encerramento das atividades de mineração, em que o volume de investimentos aplicados pode ser muito pequeno quando comparado às demais etapas do processo produtivo mineiro (MACKAYSEY, 1991a). Sobre isto, destaca-se a importância da oportunidade de aproveitar os equipamentos utilizados na movimentação de terra existentes em uma mina ativa, para construir a paisagem desejada, pois a remobilização dessas máquinas certamente se tornará muito cara (ARNOULD, 1989).

O uso de critérios arquitetônicos (diversificação do espaço, escala humana e inclinação de paredes) na elaboração e execução do plano de lavra, também devem ser consideradas no caso de pedreiras em áreas urbanas (TONSO, 1994). Objetiva-se reduzir o desconforto humano em relação ao resultado final da mineração e permitir que o uso seqüencial do espaço ocorra quase naturalmente, ao final da atividade extrativa.

A legislação estadual que iniciou a regulamentação da recuperação de áreas degradadas por mineração em SP (Resolução SMA 18/89), indica o Roteiro Básico de Elaboração de Plano de Recuperação de Áreas Degradadas, compreendendo os seguintes tópicos principais: informações gerais, histórico da área, caracterização do sítio (localização geográfica, uso e ocupação do solo, legislação incidente, geologia local, hidrogeologia, pedologia), caracterização do empreendimento (aspectos gerais, configuração atual da área, estágio atual da lavra, plano de desenvolvimento da atividade mineral, medidas mitigadoras existentes) e, finalmente, o plano de recuperação da área propriamente dito.

No que se refere ao item sobre o plano de recuperação, o Roteiro da Resolução SMA 18/89 solicita, entre outros aspectos, as seguintes informações: profundidade máxima prevista; uso do solo proposto; medidas para restabelecer o escoamento pluvial e fluvial perturbados; inclinação e cobertura dos taludes; destinação dos estéreis e rejeitos não utilizados na recuperação; destinação de cavas inundadas; desenho com a configuração final da área; cronograma de execução e custos; termo de responsabilidade do empreendedor quanto à execução dos trabalhos; assentimento do proprietário do solo; e equipe técnica responsável pela elaboração do plano. Além disso, o Roteiro exige a apresentação de relatório anual de execução dos trabalhos de recuperação, ilustrado com fotos que evidenciem o progresso da recuperação.

No quadro de normas técnicas, a NBR 13030 que trata da "Elaboração e apresentação de projeto de reabilitação de áreas degradadas pela mineração" (ABNT, 1993), fixa as diretrizes para o projeto de reabilitação de áreas mineradas, visando a obtenção de subsídios técnicos que possibilitem a manutenção e/ou melhoria da qualidade ambiental. Em seu anexo, a norma apresenta um roteiro contendo os itens para o projeto, considerando a descrição geral 
do empreendimento, o diagnóstico ambiental, os impactos ambientais, a aptidão e intenção de uso futuro, a conformação topográfica e paisagística, o programa de acompanhamento e monitoramento das medidas, cronograma, referências bibliográficas, equipe técnica e os anexos necessários (desenhos, fotografias, mapas, planilhas de custo, entre outros).

Em síntese, a partir da identificação e avaliação inicial, o planejamento da recuperação de uma área degradada por mineração pode ser resumido na execução dos seguintes procedimentos básicos:

a) estabelecimento do compromisso do empreendedor com os trabalhos de recuperação;

b) avaliação detalhada da área degradada (no caso da avaliação inicial ou expedita não ter sido suficiente), envolvendo a identificação dos processos de degradação, identificação dos impactos ambientais existentes e definição dos indicadores ambientais; c) definição dos objetivos da recuperação, compreendendo o estabelecimento dos resultados ou metas a serem alcançados a curto e médio prazos e a definição do uso pós-mineração;

c) elaboração de um plano ou projeto de recuperação, compreendendo a escolha dos métodos e técnicas que serão empregados na recuperação, descrição dos procedimentos e medidas que serão adotados, formulação de um programa de monitoramento e manutenção das medidas implementadas, análise do uso pósmineração frente a outras alternativas de uso futuro da área; estabelecimento de um cronograma dos trabalhos e previsão dos recursos humanos, materiais e financeiros que serão necessários.

\subsubsection{Métodos e técnicas de recuperação}

A recuperação de áreas degradadas envolve a definição de estratégias ou métodos de recuperação e a escolha das medidas a serem implementadas. O dimensionamento das medidas deve ser balizado pela avaliação da degradação realizada anteriormente e pelos indicadores e parâmetros ambientais utilizados. Quanto maior a defasagem entre os valores dos parâmetros obtidos na área degradada e os desejados, tanto por estratégias específicas de quem está empreendendo a recuperação quanto por exigências legais, maior certamente serão os recursos que deverão ser alocados para o ajuste (redução, aumento ou eliminação dos valores dos parâmetros).

A escolha dos métodos requer análise cuidadosa das alternativas tecnológicas disponíveis e da provável eficácia que as medidas terão na correção ou estabilização da degradação. BITAR, BRAGA (1995) reconhecem três grandes conjuntos de alternativas 
aplicadas à recuperação de áreas degradadas, distingüidas em função da predominância do campo do conhecimento científico que as fundamentam: revegetação, geotecnologias e remediação, visando sobretudo a estabilidade biológica, física e química do ambiente, respectivamente. Todavia, na prática, as medidas são comumente aplicadas de modo combinado.

Alguns manuais específicos sobre a recuperação de áreas degradadas por mineração têm sido elaborados e editados com conteúdos que ilustram a diversidade de medidas possíveis e segundo a aplicação integrada de diferentes técnicas, como os de BAUER (1970), COPPIN, BRADSHAW (1982), SENDLEIN et al. (1983), HOLMBERG, HENNING (1983), LYLE JR. (1987), CARCEDO, FERNANDEZ (1989) e ALBA (1995).

Normas legais aplicáveis aos casos de mineração de areia por dragagem e por desmonte hidráulico, em cava submersa ou leito de rio em SP (Normas Cetesb D7.010/90 e D7.011/90, respectivamente), indicam o uso de medidas diversas, como a remoção, estocagem e utilização do solo orgânico, a instalação de bacia de decantação de finos e a construção de sistema de tratamento e disposição de efluentes sanitários.

A recuperação executada concomitantemente à mineração contempla a integração de diversas medidas às várias etapas e operações que compõem o processo produtivo mineiro, como no caso previsto da mina de amianto da S.A. Mineração de Amianto- Sama em Minaçu, GO (ALMEIDA et al., 1992).

Há diversos tipos de medidas de recuperação praticadas no País, como nas minas de ferro da Samarco Mineração em MG, ouro da Rio Paracatu Mineração- RPM em MG, carvão da Copelmi no RS, ferro da Minerações Brasileiras Reunidas- MBR em MG, bauxita da Mineração Rio do Norte no PA, fosfato da Arafértil em MG, nióbio da Companhia Brasileira de Metalurgia e Mineração- CBMM em MG, areia da Mineração Viterbo Machado Luz em SP e brita da Pedreira Embu em SP, estas duas últimas na RMSP (BRASIL MINERAL, 1989; IBRAHIM, 1996).

Considerando apenas as medidas que têm como objetivo assegurar a estabilidade do ambiente a curto ou médio prazo, os métodos e técnicas de recuperação tendem a ser distinguidos de acordo com os meios principais utilizados para alcançar a estabilização: revegetação; medidas geotécnicas; e remediação. A execução das medidas decorrentes, pode, eventualmente, independer do tipo de uso futuro do solo.

\subsubsection{Revegetação}

Estes métodos envolvem desde a fixação localizada de espécies vegetais (herbáceas, arbustivas e arbóreas) até a implantação de reflorestamentos extensivos, tanto para fins de preservação ou conservação ambiental quanto para objetivos econômicos, incluindo a geração 
de condições propícias ao repovoamento da fauna e àregeneração de ecossistemas primitivos ou originais.

Para CARCEDO et al. (1989), a revegetação sempre desempenha papel importante, pois possibilita a restauração da produção biológica do solo, a redução e controle da erosão, a estabilização dos terrenos instáveis, a proteção dos recursos hídricos e a integração paisagística.

Discussão sobre avanços recentes na recuperação de áreas degradadas por mineração, com base em estudos de caso no Canadá, Austrália e África do Sul, em diferentes tipos de minas, paisagens e condições climáticas, destaca o uso de técnicas de revegetação voltadas para o controle e estabilização de depósitos de rejeito (KENNEDY, 1992).

No Brasil, técnicas de revegetação vêm sendo aplicadas há muitos anos, sobretudo a partir do final da década de 70 em minerações de grande porte, como se vê nos trabalhos pioneiros sobre áreas lavradas realizados em minas de bauxita em Poços de Caldas, MG, pela Alcoa Alumínio (WILLIANS, 1984) e em áreas afetadas pelas obras de instalação do projeto de aproveitamento do minério de ferro na Serra dos Carajás, PA, pela Companhia Vale do Rio Doce- CVRD (FREITAS et al., 1984).

No caso de Poços de Caldas, a revegetação foi precedida de terraceamento, com plantio predominante de mudas de espécies nativas arbustivas e arbóreas ao longo das bermas, protegidas por espécies exóticas (Eucalyptus saligna ou grandis) ou nativas, como bracatinga (Mimosa scabrela), plantadas nas cristas dos taludes; com o tempo, as exóticas são eliminadas para permitir o desenvolvimento das nativas.

Em Carajás, na área da mina de ferro, os trabalhos foram conduzidos segundo a aplicação de duas técnicas de revegetação: hidrossemeadura (aspersão de sementes herbáceas em meio aquoso), visando a proteção e estabilização de cerca de $1.100 .000 \mathrm{~m}^{2}$ de superfícies e taludes de cortes contra a ação erosiva das águas pluviais, consorciando espécies gramíneas de crescimento rápido (Brachiaria decumbes e Melinis minutiflora) com espécies leguminosas (Calopogonium mucunoides e Centrosema pubescens); e plantio manual (abertura de covas, adubação orgânica, plantio, coroamento e adubação inorgânica) de cerca de 11.000 mudas de espécies árboreas nativas e exóticas, no período entre setembro de 1983 a março de 1984, nas áreas degradadas pelas atividades de terraplenagem do empreendimento (áreas de empréstimo, área industrial da mina e área do acampamento provisório).

Estudos recentes no empreendimento da CVRD, em Carajás, constataram que a revegetação atinge atualmente $3.000 .000 \mathrm{~m}^{2}$, a hidrossemeadura tem sido aplicada ao ritmo de $150.000 \mathrm{~m}^{2} /$ ano e que entre 1982 e 1990 foram plantadas cerca de 500.000 mudas (CAVALCANTI, 1996). 
Técnicas de revegetação também têm sido aplicadas e desenvolvidas em áreas de dépositos de rejeitos e estéreis, como os experimentos no uso de espécies herbáceas espontaneamente fixadas na área da mineração, visando o controle dos processos de erosão verificados nos taludes dos corpos de bota-fora da mina de amianto da Sama em Minaçu, GO (FORNASARI FILHO et al., 1986).

As medidas de recomposição vegetal têm sido predominantes em meio aos demais trabalhos de recuperação ambiental executados por minerações, como na Companhia Vale do Rio Doce- CVRD em suas minas de ferro em Itabira, MG, ferro e cobre em Carajás, PA e ouro em Teofilândia, BA. Destaca-se o uso da técnica de hidrossemeadura em áreas de disposição de estéril e em áreas de empréstimo, com uso de gramíneas e o plantio manual de espécies nativas e frutíferas (CAVALCANTI, 1996).

Os trabalhos de recuperação efetuados em oito grandes minas de diferentes regiões do Brasil foram avaliados por BARTH (1989), que verificou o predomínio de práticas de revegetação com o objetivo de alcançar, a curto prazo, uma resposta visual imediata e um efeito paisagístico agradável. Conclui que a maior parte das empresas não se dedica ao planejamento dos trabalhos e não tem objetivos de longo prazo, apontando também a necessidade de utilizar espécies nativas com base na observação da dinâmica dos ecossistemas primitivos, sob pena de que os objetivos da recuperação não se sustentem a longo prazo.

Baseado no desenvolvimento de diversas experiências, sobretudo em grandes minas no País e no exterior, o manual de WILLIANS et al. (1990) apresentam diversas técnicas e propõem uma seqüência de atividades para a execução da revegetação em áreas degradadas por mineração: planejamento; obras de drenagem na área a ser lavrada; remoção da cobertura vegetal; decapeamento e abertura da cava (armazenamento da camada fértil do solo e deposição do estéril); lavra e beneficiamento; recomposição topográfica (preenchimento da cava com estéril, rejeito e solo e aspectos paisagísticos); trato da superfície final (colocação da camada fértil do solo, descompactação e correção da fertilidade); controle da erosão; revegetação (preparo do solo, seleção de espécies e plantio ou semeadura); manutenção; monitoramento; e uso futuro do solo.

MASCHIO et al. (1992), ao analisarem diversos trabalhos de pesquisa em revegetação de áreas degradadas realizados entre 1977 e 1991 no País, tanto em mineração como em outros tipos de empreendimentos (urbanização, barragens), verificam que $46 \%$ versam sobre espécies nativas, $8 \%$ sobre exóticas e $46 \%$ sobre experiências com ambas.

Para as minerações de agregados utilizados em construção civil, SILVA et al. (1994) propõem, para o caso das extrações de areia instaladas em setores considerados por lei como áreas de preservação permanente na região do Vale do Paraíba, SP, a recuperação por meio de revegetação, com base em modelos sucessionais em duas etapas: a primeira, através do 
plantio de espécies pioneiras e secundárias iniciais, mais agressivas e de rápido crescimento, de modo a propiciar as condições necessárias ao enriquecimento posterior; e a segunda, através do plantio de espécies arbóreas secundárias tardias e climáxicas, de modo a aumentar a biodiversidade local e reabilitar as áreas de preservação permanente para que cumpram seu papel natural de abrigar a flora e fauna silvestre, proteger o solo e os recursos hídricos e propiciar a melhoria da paisagem. Nas áreas situadas ao longo da margem do rio, recomendam o plantio misto de espécies nativas. Nas bordas das cavas e outras áreas não consideradas de preservação permanente, sugerem o plantio homogêneo de espécies exóticas na primeira etapa, em razão do baixo custo e maior eficiência na proteção e estabilização do solo.

Algumas deficiências no desenvolvimento do solo foram observadas por WEISSBERG (1995) ao comparar características estruturais de solos (microestrutura, arranjo e distribuição dos poros) em áreas submetidas, há até 12 anos, a métodos de revegetação em antigas frentes de extração de bauxita da Alcoa Alumínio, em Poços de Caldas, MG, com solos em áreas ainda não lavradas. Discute o papel desempenhado pelo calcário utilizado na correção da acidez do solo, como possível causador dos problemas, constatando, entretanto, o bom desenvolvimento da serapilheira e da vegetação rasteira (capim gordura), sendo esta última controlada com o uso de espécies sombreadoras (leguminosas) que a transformam em adubo verde.

Os avanços significativos nas práticas desenvolvidas na revegetação de áreas degradadas por minerações no País nos últimos anos, tanto no uso de espécies nativas como de exóticas, têm sido reconhecidos recentemente por alguns autores (GRIFFTH, 1994; GRIFFTH et al.,1996). Constatam que a abordagem utilizada atualmente se caracteriza pela busca da melhoria dessas práticas, mas que, conforme observou BARTH (1989), isto não garante, a longo prazo, o sucesso da revegetação.

Assim, embora reconhecendo que trabalhos com exóticas podem ter relevância, GRIFFTH et al. (1996) destacam e analisam os resultados de pesquisas com o uso de espécies nativas e propõem uma abordagem alternativa, reformando as práticas atuais com base no que denominam de modelo bioeconômico ideal, executado em duas fases: a primeira, composta de "rápido crescimento da vegetação em locais degradados e preparados também para receber, posteriormente, propágulos provenientes das comunidades naturais da região e facilitar sua germinação e crescimento em comunidades vegetativas mais evoluídas"; e a segunda, com "manipulação da dinâmica sucessional para alcançar uma paisagem auto-sustentável e harmoniosa, de acordo com o uso da terra previsto no programa de recuperação da área" (GRIFFTH et al., op. cit., p.31).

Em síntese, estas formulações sugerem uma tendência crescente em substituir os métodos atuais de revegetação com uso de arbóreas, tanto no plantio exclusivo de exóticas, 
visto que não garantem o sucesso da revegetação, quanto no de nativas, visto que têm sido muito caros e demorados, ou mesmo misto, adotando-se as práticas de manejo e indução da revegetação natural ou espontânea.

\subsubsection{Medidas geotécnicas}

Métodos de fundamentação geotécnica podem envolver desde a execução de medidas simples até obras de engenharia relativamente complexas. As medidas ou obras geotécnicas podem ser com ou sem estruturas físicas de contenção ou retenção, sendo aplicadas no controle de processos do meio físico que atuam na degradação do solo. Visam, portanto, a estabilização física do ambiente e geralmente compreendem procedimentos técnicos da Mecânica dos Solos, Mecânica das Rochas e Geologia de Engenharia que, integradamente, constituem a geotecnia (SANTOS et al., 1990) ou, segundo VARGAS (1994), a geotecnologia.

Em mineração, há uma ampla variedade de procedimentos geotécnicos possíveis envolvendo terraplenagem, sistemas de drenagem e retenção de sedimentos, barragens ou diques de bacias de disposição de rejeitos de beneficiamento, contenção de taludes de cortes e em corpos de bota-fora, entre outros (IBRAM,1992).

Estudos sobre diretrizes para a recuperação de áreas degradadas por minerações de areia na RMSP, desenvolvidos em IPT (1988) e sintetizados em BITAR et al. (1990), resultaram na indicação de diversas medidas voltadas principalmente à estabilização de processos do meio físico. As medidas são abordadas segundo os diferentes contextos geológicos, geomorfológicos e de uso do solo em que a atividade mineral se realiza.

A estabilidade de taludes marginais em lago de extração de areia, situado em planície aluvionar no município de Carapicuíba, na RMSP, é examinada quanto à probabilidade de rupturas e riscos à circunvizinhança, apontando-se medidas de recuperação do meio físico (AUGUSTO FILHO, 1992).

Medidas para a recuperação ambiental de áreas de extração de material de empréstimo em morros, a partir de solo de alteração de rochas cristalinas, têm sido propostas também com ênfase no controle de processos do meio físico, como em Iguape, SP (BRAGA et al., 1996) e em Embu, na RMSP (IPT, 1994; VASCONCELOS et al., 1996).

Considerações a respeito das barragens de rejeito associadas à mineração de areia em Araçariguama, SP, município contíguo à RMSP, foram apresentados em IPT (1995). O estudo aponta medidas destinadas àmelhoria da eficiência das barragens na decantação dos finos e à sua estabilidade de modo a evitar possíveis rupturas e assegurar a retenção dos rejeitos.

Alguns procedimentos têm sido objeto de normas técnicas aplicadas à recuperação de áreas degradadas por mineração, como os da norma NBR 13028, que trata da "Elaboração e 
apresentação de projeto de disposição de rejeitos de beneficiamento, em barramento, em mineração" (ABNT, 1993). Fixam-se as condições exigíveis para atender especificidades de segurança, higiene, operacionalidade, economia, abandono e minimização dos impactos ambientais, dentro dos padrões legais e de outras normas correlatas como a NBR 10004 ("Resíduos sólidos- Classificação") e a NBR 10157 ("Aterros de resíduos perigosos- Critérios para projeto, construção e operação- Procedimento"), além de normas internacionais.

Em seu anexo, a NBR 13028 apresenta um roteiro para o projeto, contendo os seguintes itens: introdução, informações gerais do empreendimento, apresentação do projeto (objetivo, localização e características do sítio do barramento e bacia hidrográfica, dados utilizados para o projeto, estudo de alternativas, estudos hidrológicos, hidráulicos e sedimentológicos, estudos hidrogeológicos, estudos geológico-geotécnicos- estes incluindo fundação, materiais de construção e rejeito- e descrição do barramento), descrição do sistema de transporte e lançamento de rejeito, análise e dimensionamento das obras componentes do barramento, impacto ambiental, monitoramento, medidas para desativação, cronograma do empreendimento, documentos de referência, e profissionais envolvidos no projeto.

Em outra norma, a NBR 13029, sobre "Elaboração e apresentação de projeto de disposição de estéril, em pilha, em mineração" (ABNT, 1993), fixam-se as condições exigíveis para estéreis gerados na lavra a céu aberto ou subterrânea, visando atender os aspectos de segurança, higiene, operacionalidade, economicidade, abandono e minimização dos impactos ambientais, dentro dos padrões legais e de normas como a NBR 10006 ("Solubilização de resíduos- Procedimento").

O anexo da norma NBR 13029 recomenda os seguintes itens para o projeto a ser elaborado: introdução, informação geral do empreendimento, apresentação do projeto (objetivo, localização e características físicas do sítio da pilha, dados utilizados para o projeto, estudo de alternativas, estudos hidrometeorológicos, estudos hidrogeológicos, estudos geológico-geotécnicos, descrição da pilha), análise e dimensionamento das obras componentes do sistema de disposição de estéril, aspecto ambiental, monitoramento, medidas para o abandono, cronograma, equipe técnica envolvida no projeto e os anexos correspondentes.

\subsubsection{Remediação}

Estes métodos envolvem o uso de técnicas de tratamento que visam eliminar, neutralizar, imobilizar, confinar ou transformar elementos ou substâncias contaminantes presentes no ambiente e, assim, alcançar a estabilidade química do ambiente. No caso de solos e águas subterrâneas contaminados, os métodos geralmente envolvem técnicas de 
tratamento "in situ". No caso das águas superficiais, sedimentos, lodos ou lixiviados, especialmente quando se objetiva restabelecer padrões de qualidade ambiental, caracterizamse como técnicas de saneamento. Comumente, as técnicas de remediação compreendem processos químicos, mas, dependendo do caso, podem envolver também processos físicos ou biológicos.

Em depósitos de resíduos, o que compreende certos tipos de rejeitos de mineração, há uma tendência mundial de priorizar tecnologias de tratamento "in situ". Estas técnicas permitem solucionar o problema no próprio local da contaminação, sem a necessidade de transportar materiais contaminados para tratá-los em outra área, reduzindo muito os custos operacionais, entre outros problemas e riscos adicionais. Isto atribui importância maior ao conhecimento das condições dinâmicas do solo e subsolo contaminado, tanto da zona saturada como da nãosaturada. Eventual desconhecimento destas condições, especialmente em termos hidrogeológicos, pode levar os agentes do tratamento a serem desviados para longe da área alvo, ampliando o alcance da contaminação e, ainda, limitando a efetividade da remediação (ESTADOS UNIDOS DA AMÉRICA, 1990).

Métodos aplicados em lagos e represas contaminados pela urbanização e industrialização vêm sendo desenvolvidas desde o início da década de 60, na Suécia, França e EUA, entre outros países industrializados. Estes métodos visam eliminar problemas como eutrofização e desoxigenação dos corpos d'água, sendo que os tratamentos se aplicam diferenciadamente às cargas poluidoras a montante, à coluna d'água e aos sedimentos, consistindo de aeração ou oxigenação entre outros. A agência de proteção ambiental dos EUA lançou em 1972 um programa especial para recuperação da qualidade das águas de lagos denominado "Clean Lake Program", que financiou mais de 450 projetos até o início da década de 90 (MORIN, 1992).

Sobre solos e águas contaminados, técnicas de remediação similares às apresentadas em ESTADOS UNIDOS DA AMÉRICA (1990) são discutidas em ROEHRIG, SINGER (1996), com base em exemplos de uso em escala piloto e real de outros países, em especial dos EUA, analisando o potencial de aplicação æ̀ áreas urbanizadas e industrializadas, como a RMSP. Destacam as situações geradas pela disposição inadequada de resíduos no solo, bem como os acidentes durante o transporte, estocagem e tratamento de resíduos e de matérias-primas. Dentre as principais técnicas, citam incineração, pirólise, vitrificação, lavagem do solo com água ou produtos químicos, extração de vapor do solo com ar ou vapor d'água, dessorção de compostos voláteis na água com ar ("air stripping"), oxidação, redução, descloração com glicolato, ozonização, polimerização, microencapsulamento, barreiras verticais, cobertura superficial e biorremediação.

Há notícias recentes, divulgadas pelos meios de comunicação, sobre pesquisas tecnológicas de fitorremediação nos EUA, cujo objetivo consiste em retirar contaminantes 
presentes no solo (especialmente metais, como $\mathrm{Pb}, \mathrm{Cd}$ ou $\mathrm{Cu}$ ), por meio de plantio e desenvolvimento de mudas de certas espécies. A técnica estaria sendo testada também em solos contaminados por radioatividade, como no caso do acidente ocorrido em 1986 na usina nuclear de Chernobyl, Ucrânia (à época, compondo a União das Repúblicas Socialistas Soviéticas- URSS).

No caso da mineração, técnicas de remediação têm sido aplicadas principalmente aos depósitos de rejeitos de beneficiamento, como no caso das bacias de sedimentação no processo produtivo do minério de nióbio, da Companhia Brasileira de Mineração e MetalurgiaCBMM em Araxá, MG, em que se detectou a presença de $\mathrm{Ba}$ nas águas subterrâneas a jusante.

Outra situação peculiar à mineração corresponde ao caso de drenagens ácidas provenientes especialmente de minas de minerais metálicos e de carvão e que se torna atualmente uma das questões ambientais mais importantes em países como EUA, Canadá, África do Sul e da Europa, especialmente a partir do encerramento da atividade produtiva (BROUGHTON, HEALEY, 1992).

Drenagem ácida de mina ("acid mine drainage"- AMD) tem sido considerada como o processo de formação e movimentação de águas muito ácidas e ricas em metais pesados (KING et al., 1995). O pH dessas águas pode ser menor que 2, mas comumente se situa entre 2 e 5. A formação das águas ácidas ocorre principalmente através de reações químicas das águas superficiais e subterrâneas com rochas ou materiais (como rejeitos e estéreis) que contêm sulfetos, especialmente pirita, resultando em ácido sulfúrico e sulfato férrico. Os metais pesados podem ser lixiviados no contato com o ácido, em um processo que tende a ser intensificado pela ação bacteriana. Os fluídos resultantes podem ser altamente tóxicos e quando misturados às águas superficiais e subterrâneas e ao solo, podem gerar efeitos danosos ao homem, animais e plantas.

KING et al. (1995) enfatizam a preocupação com a dimensão dos problemas de drenagem ácida ao estimar entre 100.000 e 500.000 a quantidade de áreas abandonadas ou minas desativadas nos EUA, muitas das quais em lavras antigas de minerais metálicos. Lembram que, historicamente, quando deixam de apresentar interesse econômico, as minas são abandonadas com pouca ou mesmo nenhuma consideração sobre os futuros impactos ambientais. Exemplificam a significância do problema com os estudos sobre drenagem ácida efetuados na mina de ouro de Summitville, estado do Colorado, abandonada em 1992 e que teve seus custos de remediação estimados pela agência de proteção ambiental dos EUA entre 100 a 120 milhões de dólares.

No Brasil, o problema da drenagem ácida é reconhecido há muito tempo nas regiões carboníferas do sul, especialmente em SC, sendo relativamente mais recente a preocupação em minas de ouro, metais básicos e outros minerais cujos depósitos de estéril contém sulfetos. 
Segundo RITCEY (1995), as medidas de remediação aplicadas à mineração se concentram especialmente em: controle da geração de ácidos, podendo envolver condicionamento, segregação e mistura, bactericidas e aditivos alcalinos, coberturas orgânicas e inorgânicas, selos, deposição subaquática, entre outras; controle da migração de contaminantes, com uso de coberturas (barreira ao oxigênio e àinfiltração de água, controle de erosão) e técnicas de deposição; e coleta, armazenamento e tratamento ativo (processos químicos e físicos) ou passivo ("wetlands", redução de sulfatos, trincheiras anóxidas) das águas ácidas.

Estudos de campo e laboratório feitos em amostras do material de duas pilhas de estéril foram conduzidos por SOUZA (1995) na mina de urânio do planalto de Poços de Caldas, em Caldas, MG, de modo a caracterizar o processo de geração de ácidos, sobretudo ácido sulfúrico, avaliar as implicações ambientais e subsidiar a definição de medidas corretivas.

No entanto, MARKER et al. (1993) sugerem que, no caso da RMSP, as atividades de mineração não têm contribuído signicativamente para a geração de áreas contaminadas, particularmente quando comparadas às demais atividades econômicas na metrópole como indústrias metalúrgicas, mecânicas, químicas, farmacêuticas, plásticos, têxteis, entre outras, o que tende a restrigir a aplicação de medidas de remediação. Isto se deve provavelmente às características da mineração na RMSP e a predominância na produção de agregados, em que o uso de insumos químicos e a geração de resíduos contendo elementos ou substâncias perigosas são pouco freqüentes.

As exceções na RMSP podem estar em algumas minas de ouro, antigas, pequenas e abandonadas e, no caso de minas ativas, no processo de beneficiamento de alguns empreendimentos de produção de agregados, como os de areia, que podem utilizar substâncias químicas para floculação de argilas em bacias de decantação, ou de caulim, que adicionam, nos tanques de sedimentação, composto de pó de $\mathrm{Zn}, \mathrm{H}_{2} \mathrm{SO}_{4}, \mathrm{H}_{3} \mathrm{PO}_{4}$ e $\mathrm{SO}_{2}$, objetivando o branqueamento do concentrado por meio de reagentes auxiliares (CHAVES, 1996). Nestes casos, reconhece-se o uso de $\mathrm{Na}_{2} \mathrm{CO}_{3}$ (barrilha) e $\mathrm{CaO}$ nas águas residuárias visando a correção do pH (IPT, 1991).

\subsubsection{Monitoramento e manutenção}

As medidas de recuperação executadas requerem vistorias e inspeções periódicas, visando manter as condições necessárias ao cumprimento dos objetivos preestabelecidos no plano de recuperação.

A eficácia das medidas adotadas deve ser acompanhada por meio de indicadores ambientais que, nesta atividade, podem ser denominados como indicadores de desempenho, 
visando verificar se os parâmetros estão sendo ajustados e se a recuperação está sendo ou não bem sucedida. Eventuais resultados insatisfatórios podem exigir desde a reavaliação da área degradada e a reformulação das medidas executadas até, se necessário, sua complementação ou substituição.

Entre exemplos de indicadores de desempenho adotados na recuperação de áreas degradadas por mineração, podem ser citados os que se aplicam à revegetação, como no Projeto Carajás em que se planejou o monitoramento do plantio manual pela quantidade $\left(\mathrm{n}^{\circ}\right)$ e altura $(\mathrm{m})$ de mudas sobreviventes (FREITAS et al., 1984). No caso de medidas geotécnicas destinadas a aferir a eficiência de sistemas de retenção de sedimentos, há o exemplo da comparação entre o volume $\left(\mathrm{m}^{3}\right)$ e área ocupada (ha ou $\mathrm{m}^{2}$ ) pelo material acumulado na bacia e pelos depósitos de assoreamento situados a jusante. Em medidas de remediação aplicadas aos problemas de drenagem ácida, há o $\mathrm{pH}$ das águas captadas a montante e a jusante, entre outros.

\subsection{Usos pós-mineração}

As citações sobre usos futuros de áreas de mineração, encontradas principalmente na literatura internacional, têm revelado uma ampla gama de possibilidades. Casos de habitação, agricultura, pastagens, comércio, indústria, disposição de resíduos, reflorestamento, lazer, recreação, esportes, preservação e conservação ambiental, piscicultura, entre outras formas de uso e ocupação do solo, vêm sendo, há muito tempo, lembrados como alternativas de recuperação ou reabilitação para áreas de diferentes bens minerais em países industrializados como EUA, Canadá, França, Alemanha e outros.

Uma das principais questões colocadas se relaciona ao período em que as atividades de reabilitação devem ser iniciadas. Preferencialmente, os procedimentos para a efetiva instalação de um uso pós-mineração devem ser estabelecidos antes da atividade extrativa e iniciados durante as primeiras fases do seu desenvolvimento. Os diversos problemas que tendem a ocorrer nos casos em que esses procedimentos são iniciados no período final da explotação, bem como após o encerramento das atividades de mineração e eventual abandono das áreas degradadas, podem dificultar muito ou mesmo impedir a instalação de novos usos, sobretudo em face dos enormes recursos financeiros que geralmente são necessários nessas situações para a recuperação. Desta forma, a incorporação do processo de reabilitação ao cotidiano da mineração, impõe-se como diretriz fundamental para alcançar o sucesso do uso pós-mineração (BAUER, 1989b; ZIMMERMAN, 1990; MACKASEY, 1991b; MARSH, 1994).

Trabalhos sobre procedimentos operacionais para a progressiva e concomitante reabilitação de áreas de mineração têm sido realizados em diversos países industrializados, 
como nos EUA onde, desde a década de 60, diversos trabalhos foram executados. Estudos pioneiros sobre agregados para construção civil (JOHNSON, 1966; JENSEN, 1967; BAXTER, 1969; BAUER, 1970), seleção de usos do solo em mineração de areia industrial (SCHELLIE, BAUER, 1968), entre outros, foram compilados por SCHELLIE (1977), que aborda a mineração como um uso temporário ou transitório do solo e, ao citar a possibilidade de uso para aterros sanitários seguida de instalações industriais, configura o conceito de uso seqüencial.

Sobre agregados em áreas urbanas, BAUER (1989b) relata diversos casos nos EUA, Canadá e Alemanha que resultaram em loteamentos, agricultura, parques, usos recreativos, entre outros, ressaltando que qualquer atividade pode ser instalada em uma área de antiga extração de areia ou pedreira.

Outros exemplos nos EUA e em países da Europa são mencionados em CARTER (1990a e 1990b), MENCACCI, CARTER (1989) e RUKAVINA (1991), compilados em SÁNCHEZ (1995) que, por sua vez, ressalta o fato de que a maior parte dos projetos executados foram patrocinados pelas empresas de mineração e tiveram alguma forma de participação da comunidade. O caso específico de aterro sanitário é discutido em CARTER (1989a), ressaltando a possibilidade de ser também um empreendimento lucrativo.

Há diversos exemplos de áreas reabilitadas no Brasil e na RMSP, como os citados em SINTONI et al. (1994) e em IBRAHIM (1996), destacando casos de usos industriais e de parques públicos, como o do Parque Cidade de Toronto, em São Paulo, SP (ARCHANGELETTI et al., 1993). No entanto, a maior parte dos casos mencionados não decorre de um plano elaborado, executado ou patrocinado pela empresa de mineração que realizou a atividade extrativa, mas sim de iniciativas pós-mineração tomadas pelo estado ou prefeituras municipais com o objetivo de viabilizar projetos públicos.

Dentre as orientações gerais contidas em manual técnico para empreendimentos minerais na RMSP (SÃO PAULO, 1982), incluem-se: rearranjo da área para loteamentos urbanos; aproveitamento da área para implantação de projetos industriais; reaterro simples para desenvolvimento de atividades agrícolas; utilização das cavas resultantes da explotação mineral para depósito de rejeitos sólidos e aterros sanitários; e projetos destinados a proporcionar áreas de lazer à comunidade, como área verde, parques esportivos, lagos, anfiteatros, museus, entre outros. Todavia, o uso planejado e adequado de áreas degradadas por mineração para a disposição de resíduos representa, na prática, um desafio tecnológico e gerencial às metrópoles brasileiras (BITAR et al.,1993b).

Potencialmente, existem diversas possibilidades de uso para uma mesma área degradada por mineração, como se vê, entre outros, nos estudos prospectivos sobre o caso das extrações de argilas em Campina Grande, PB (SILVA, 1995).

No Estado de São Paulo, a crescente tendência pelo uso de cavas abandonadas para a destinação de resíduos inertes (classe III da norma NBR 10004 sobre classificação de resíduos 
sólidos, da ABNT) levou a Secretaria de Estado do Meio Ambiente- SMA a editar uma diretriz legal (Resolução SMA- 25/96), estabelecendo um Programa de Apoio aos Municípios que pretendam utilizar essas áreas para disposição de materiais como entulho de demolição e obras de terraplenagem.

A observação das características de projetos bem sucedidos de reabilitação de áreas degradadas por mineração em países desenvolvidos, permite destacar os seguintes aspectos comuns: os planos de uso do solo pós-mineração consideram o ambiente natural e cultural da região; os objetivos da recuperação e do uso do solo pós-mineração são bem definidos; o responsável pelas operações no sítio geralmente mantém uma atitude pró-ativa em relação aos trabalhos de recuperação; a recuperação é conduzida concomitantemente à mineração; e os usos do solo pós-mineração são gerenciáveis e sustentáveis (DIETRICH, 1990).

\subsection{Custos de recuperação}

Em projetos de mineração, as despesas com os trabalhos de recuperação de áreas degradadas geralmente se encontram diluídas em meio aos gastos com as demais atividades de planejamento e gerenciamento ambiental executadas no âmbito dos empreendimentos. Por sua vez, os gastos totais com a execução de medidas ambientais, inclusive as de recuperação, estão comumente incluídos nas demais despesas operacionais. Assim, são raros os casos de contabilização das medidas ambientais em minerações e, mais ainda, os que discriminam os custos de recuperação.

Estudos realizados em diferentes empreendimentos da Companhia Vale do Rio DoceCVRD (ferro em Itabira, MG, ferro e ouro em Carajás, PA e ouro em Teofilândia, BA) expressam, nas discussões comparativas sobre os custos ambientais, as dificuldades e deficiências de contabilização (CAVALCANTI, 1996).

Os dados disponíveis geralmente permitem uma estimativa apenas quanto æ̀s despesas ambientais totais. É o caso, entre outros exemplos, da mina de ferro da MBR, localizada na área urbana de Belo Horizonte, MG, em que foram contabilizados gastos totais com medidas ambientais da ordem de US\$7,1 milhões/ano no período entre 1978 e 1992, valor que corresponde a $4 \%$ do total de despesas com a operação da empresa (MBR, 1992, apud CAVALCANTI, op. cit.).

Comparação entre os casos das minas de ouro da Rio Paracatu Mineração- RPM em Paracatu, MG, e da CVRD em Teofilândia, BA, mostra que os gastos ambientais totais representam, respectivamente, cerca de 7,16\% e 1,75\% em relação ao total de investimentos realizados pelas empresas em seus projetos (CASSIANO, CAVALCANTI, 1996). No caso de 
Teofilândia, esses gastos correspondem a cerca de 3,3\% das despesas de operação do empreendimento (CAVALCANTI, 1996).

\subsection{Instrumentos legais e institucionais}

A recuperação de áreas degradadas tem sido implementada em diferentes países como importante instrumento de política pública na área ambiental. As abordagens são variadas, porém geralmente perseguem o mesmo objetivo de assegurar a correção dos impactos ambientais considerados negativos e importantes (CHISHOLM, DUMSDAY, 1987).

Dois aspectos são notáveis quando se comparam as políticas implementadas em países desenvolvidos com as de países em desenvolvimento: a existência de mecanismos institucionais que objetivam assegurar recursos financeiros para a execução de projetos de recuperação e a participação da comunidade no processo decisório sobre a destinação futura das áreas degradadas. Estes aspectos são comuns em países desenvolvidos e raramente se encontram nos países em desenvolvimento.

\subsubsection{O quadro internacional}

Análise comparativa de aspectos legais relacionados ao aproveitamento de agregados em diferentes regiões do mundo revela que a recuperação de áreas degradadas é obrigatória em vários países industrializados, como EUA, França, Itália, Rússia e Canadá. Os procedimentos geralmente prevêem a participação da comunidade e são instruídos mediante estudos e planos de recuperação previamente submetidos à aprovação dos órgãos públicos locais ou regionais e, em certos casos, federais. Em geral, a recuperação deve ser executada pelo minerador, podendo ser assumida pelo governo através de recursos depositados como caução, como ocorre na província de Ontário, Canadá. Nos países da América do Sul, a obrigatoriedade da recuperação tem sido crescentemente contemplada em diplomas legais de vários países, como Brasil, Argentina, Peru, Colômbia e Uruguai, porém muito pouco exigida na aplicação da legislação (HERMANN, 1992).

No caso de Ontário, Canadá, a regulamentação sobre reabilitação prevê explicitamente a consulta pública e a possibilidade de exigência de um plano de fechamento ("closure plan") da mineração (CANADÁ, 1990).

Um balanço geral sobre dez anos de unificação da legislação relacionada ao aproveitamento de agregados (brita, cascalho e areia) na França, propicia observar que a nova regulamentação estabeleceu como diretriz geral a exigência de reconstituição da geometria original do solo, criando uma instância administrativa para examinar e opinar sobre os pedidos 
de extração mineral com representação de todos os setores envolvidos, inclusive a população diretamente afetada e as entidades ambientalistas. O resultado dessa política tem ultrapassado as exigências, gerando, em muitos casos, situações melhores que as preexistentes com a reabilitação do solo e a instalação de novas formas de utilização (ARNOULD, 1989).

No caso de agregados nos EUA, destacam-se os aspectos significativos que devem ser considerados nas relações entre o regulamentador e o público em geral: o interrelacionamento entre a mineração e a recuperação ou reabilitação; e a notificação ao órgão público e à comunidade interessada sobre a intenção de mudanças no plano aprovado, em tempo hábil para que possam haver discussões e proposições (CARTER, 1989b).

Considerando o contexto de países em desenvolvimento, BLAIKIE (1989) discute as principais tarefas que devem ser realizadas para o estabelecimento de uma política pública sobre degradação do solo: a confirmação de que a degradação está, de fato, acontecendo, segundo critérios não apenas técnicos mas também sociais; a identificação de quem considera que a degradação é ou será um problema e se é ou será afetado; a identificação de como a degradação tem ocorrido; e, finalmente, encontrar as soluções possíveis e os meios pelos quais podem ser alcançadas. Em outras palavras, esta última tarefa compreende a definição de uma política pública. Considera que uma das tarefas mais importantes na construção de uma política pública eficiente, tanto em nível nacional como regional, está na realização de uma explicitação abrangente e cuidadosa de como e porquê a degradação ocorre.

Não obstante, a falta de recursos financeiros tem sido apontada como a principal dificuldade para a implementação das políticas públicas ambientais voltadas ao setor de mineração, que começaram a ser estabelecidas na maior parte dos países em desenvolvimento, sobretudo a partir da década de 80, como na Índia (DHAR, 1994) e na Malásia (AZIZ, 1994).

De fato, um dos principais entraves práticos na execução de políticas públicas tem sido o de garantir recursos para a recuperação efetiva de áreas degradadas, sobretudo em virtude dos altos custos financeiros que podem estar envolvidos nos casos em que a degradação atinge grau elevado. Para superar isso, alguns países industrializados, como os EUA, França, Canadá e a Alemanha, estabeleceram políticas públicas específicas para a recuperação de áreas degradadas, com a criação de mecanismos diversos destinados a garantir os recursos financeiros necessários à execução das medidas corretivas. Este é o caso, por exemplo, da lei do "Superfund" nos EUA e de outras similares que criaram fundos de recuperação em algumas regiões da Alemanha e do Canadá.

O "Superfund" é a denominação comumente utilizada para se referir à lei federal instituída em 1980 nos EUA sobre áreas contaminadas ("Comprehensive Environmental Response, Compensation, and Liability Act- Cercla"), a qual estabelece um programa que visa identificar sítios em que a liberação de substâncias perigosas ao ambiente tenha ocorrido ou 
possa vir a ocorrer, apontar os responsáveis pela contaminação, avaliar os danos aos recursos naturais e criar procedimentos para a cobertura dos custos relacionados às atividades de remediação (ESTADOS UNIDOS DA AMÉRICA, 1990).

Embora de modo ainda incipiente, a evolução da regulamentação sobre mineração e meio ambiente em diferentes países em desenvolvimento e que possuem áreas metropolitanas, como no sudeste asiático (China, Índia, Indonésia, Malásia, Filipinas, Papua Nova Guiné e Tailândia), tem mostrado crescente preocupação com a necessidade de incorporação de mecanismos que assegurem os recursos para a efetiva recuperação das áreas degradadas, bem como a participação de organizações não-governamentais na formulação de políticas públicas (JAYAWARDENA, 1994). Além de fundos públicos, mecanismos de natureza privada, como seguros ambientais, também têm sido mencionados (ANDERSON, 1994; CLARK, 1994).

Assim como no Brasil, a recuperação de áreas degradadas tem sido crescentemente incluída nos procedimentos de avaliação de impacto ambiental de países em desenvolvimento, como na Indonésia (KUNTJORO, 1994) e na Mongólia (SODNOMDORJ, 1994).

Em nível global, o crescimento da degradação ambiental tem sido uma das principais questões abordadas no âmbito da Organização das Nações Unidas- ONU, particularmente desde a Conferência de Estocolmo, em 1972, que gerou, entre outras decorrências, a criação do Programa das Nações Unidas para o Meio Ambiente- PNUMA.

O Relatório da Comissão Mundial sobre Meio Ambiente e Desenvolvimento, divulgado em 1987 com o título de Nosso Futuro Comum (mundialmente conhecido como Relatório Brundtland, em alusão ao sobrenome da então primeira-ministra da Noruega, que presidiu a Comissão), representa um marco na perspectiva da busca do chamado desenvolvimento sustentável, ou seja, um desenvolvimento que permita à humanidade usufruir dos recursos naturais, sem comprometer a possibilidade de que as gerações futuras também possam. $O$ Relatório apresenta diversas proposições para reduzir as ameaças à sobrevivência da humanidade, tornar viável o desenvolvimento e interromper o ciclo causal e cumulativo entre subdesenvolvimento, condições de pobreza e problemas ambientais (KITAMURA, 1994, apud CAVALCANTI, 1996)

A Conferência das Nações Unidas sobre Meio Ambiente e Desenvolvimento, encontro global proposto em 1989 pela Assembléia Geral das Nações Unidas e realizado em junho de 1992 na cidade do Rio de Janeiro, RJ, foi convocada com o objetivo de elaborar estratégias que interrompam e revertam os efeitos da degradação ambiental. O principal produto desse encontro, a Agenda 21 (ONU, 1993), documento que estabelece um amplo programa de ação a ser implementado pelos governos, agências de desenvolvimento, órgãos das Nações Unidas e outras entidades, avalia que a crescente demanda por recursos naturais tem gerado competição e conflitos que resultam na degradação do solo. A Agenda 21 indica que a solução desse problema exige uma abordagem integrada do uso do solo, focalizando a tomada de 
decisões e a consideração simultânea das questões ambientais, sociais e econômicas. Dentre os meios para a implementação deste princípio, a Agenda 21 propõe o uso dos instrumentos e mecanismos legais internacionais sobre desenvolvimento sustentável, destacando a necessidade de aperfeiçoamento da capacidade legislativa dos países em desenvolvimento, a avaliação da eficácia dos atuais acordos internacionais e o estabelecimento de prioridades para o futuro.

De fato, a melhoria da qualidade da gestão pública no planejamento e tomada de decisões sobre recuperação ambiental em países em desenvolvimento, tem merecido destaque especial na cenário mundial, sendo apontada como uma das principais questões a enfrentar (WYANT et al., 1995; CARRIDO, 1996).

Análise dos desafios ao gerenciamento ambiental da mineração, em face dos resultados da Conferência do Rio, enfatiza a importância da inovação tecnológica e a necessidade de estabelecer políticas para promovê-la, ressaltando-se a importância do estímulo à difusão e transferência tecnológica (WARHURST, 1995). Perspectiva similar é apontada em relatório da Comissão de Desenvolvimento e Meio Ambiente da América Latina e do Caribe, ao assinalar que "um meio mais eficiente de explorar os recursos minerais da América Latina é usar tecnologia mais limpa e mais apropriada, e promover inovações tecnológicas" (COMISSÃO DE DESENVOLVIMENTO E MEIO AMBIENTE DA AMÉRICA LATINA E CARIBE, 1990, p.83).

\subsubsection{O caso brasileiro}

Apesar de algumas referências anteriores em âmbito federal e indiretamente relacionadas à recuperação de áreas degradadas, o tema foi previsto na legislação ambiental brasileira somente no início da década de 80 , através da Política Nacional do Meio Ambiente (Lei Federal 6938/81), cujo texto estabelece a "recuperação da qualidade ambiental" como um dos seus objetivos e, explicitamente, a "recuperação de áreas degradadas" entre seus princípios (caput e inciso VIII do Artigo $2^{\circ}$, respectivamente).

Posteriormente, o assunto foi alçado ao nível máximo da hierarquia legal brasileira, sendo contemplado na Constituição Federal de 1988, porém apenas para o caso da mineração. O texto constitucional determina que "aquele que explorar recursos minerais fica obrigado a recuperar o meio ambiente degradado, de acordo com solução técnica exigida pelo órgão público competente, na forma da lei " (Artigo 225, parágrafo $2^{\circ}$ ). As referências legais existentes até então sobre as relações entre mineração e meio ambiente, não explicitavam claramente o tema da recuperação (SÃO PAULO, 1987).

A regulamentação do assunto constitucional foi editada no ano seguinte à promulgação (Decreto Federal 97.632/89), estabelecendo um prazo de 180 dias para que as minerações 
existentes apresentassem um Plano de Recuperação de Áreas Degradadas- Prad aos órgãos ambientais competentes. Para os futuros empreendimentos mineiros, a norma legal prevê a apresentação do Prad no âmbito do Estudo de Impacto Ambiental e respectivo Relatório de Impacto Ambiental- EIA/Rima, documentos exigidos na legislação sobre os procedimentos de avaliação de impacto ambiental- AIA no País (Resolução do Conselho Nacional do Meio Ambiente- Conama 01/86). Normas posteriores consagram a possibilidade de dispensa de EIA/Rima para certos casos de extração de materiais de construção, prevendo, contudo, a apresentação de um Relatório de Controle Ambiental- RCA e Plano de Controle AmbientalPCA, nos quais o Prad deve estar incluído (Resoluções Conama 09/90 e 10/90).

Sobre a possível regulamentação para outros tipos de empreendimentos, SÁNCHEZ (1992a) observa que, embora o assunto no País tenha enfocado especialmente a mineração, a degradação gerada por outras atividades, como disposição de resíduos, desenvolvimento urbano e obras públicas, também deverá ser objeto de políticas específicas em futuro próximo, lembrando, ainda, que o caso de agricultura e de pastagens certamente será mais difícil de controlar. Discute os desafios à regulamentação do assunto em diferentes níveis: quanto à perda de recursos naturais, mudanças indesejadas da paisagem e como uma questão de saúde e segurança pública.

Os Estados brasileiros passaram a legislar complementarmente sobre recuperação de áreas degradadas, como em São Paulo, onde a Constituição Estadual de 1989 extrapolou o espectro dos "recursos" citados na Constituição Federal e reproduziu praticamente o mesmo enunciado da Carta Magna, substituindo apenas a expressão "recursos minerais" por "recursos naturais" . No entanto, à semelhança do âmbito federal, o Estado de São Paulo, através da Secretaria de Estado do Meio Ambiente- SMA, regulamentou o tema especificamente para o caso da mineração (Resolução SMA 18/89), estabelecendo um roteiro para a elaboração do Prad (SÃO PAULO, 1991).

As normas atuais que definem os procedimentos de licenciamento ambiental de empreendimentos mineiros em SP(Resolução SMA 26/93), prevêem que o pedido de licença deve ser instruído com outros documentos técnicos (RCA, PCA ou Prad, conforme o caso). A tramitação e análise dos documentos têm envolvido órgãos distintos do Estado (Departamento de Avaliação de Impacto Ambiental- Daia, Companhia de Tecnologia de Saneamento Ambiental- Cetesb, Departamento de Proteção de Recursos Naturais- DEPRN e, no caso da RMSP, Departamento de Uso do Solo Metropolitano- DUSM, todos atualmente vinculados à SMA e, exceto a Cetesb, que é uma companhia estatal, os demais foram reunidos sob uma mesma administração em nível de Coordenadoria (Coordenadoria de Licenciamento Ambiental e Proteção dos Recursos Naturais- CPRN) a partir de 1995.

Os primeiros anos de vigência da legislação sobre os Prads em SP se mostraram pouco efetivos. Em um universo potencial de 1.363 empreendimentos existentes, apenas 426 Prads 
foram elaborados e apresentados aos órgãos ambientais até o início de 1992, dos quais somente 46 (11\%) haviam sido analisados até então (SÁNCHEZ, 1993). Em dezembro de 1994, o número de Prads aguardando análise era de 550 (TEIXEIRA, 1995).

MURGEL et al. (1992) salientam a necessidade de um enfoque regional para agilizar e integrar a avaliação dos Prads por parte dos órgãos ambientais no Estado de São Paulo, recomendando, no caso das extrações de areia para construção civil (181 Prads protocolados na SMA até 1991), a abordagem no contexto de bacias hidrográficas. De fato, este tipo de abordagem, estabelecendo diretrizes gerais a serem cumpridas pelo conjunto de minerações existentes numa dada bacia ou região, começou a ser aplicada pelo Estado nos casos de areia no vale do rio Paraíba do Sul e em Araçariguama, ambas próximas à RMSP e, ainda, na região do município de Aguaí, bacia hidrográfica do rio Jaguari-Mirim no interior paulista, onde se concentram dezenas de empreendimentos. Em Araçariguama, o procedimento adotado incluiu a criação, por parte da Prefeitura local, de um Distrito Minerário no município, submetido, no âmbito do licenciamento ambiental, ao processo de AIA e apresentação de EIA/Rima ao Daia/SMA e ao Conselho Estadual do Meio Ambiente- Consema. No vale do rio Paraíba do Sul, dada a necessidade de disciplinar a atividade mineral em face da degradação ambiental gerada, o caso levou o Consema a estabelecer diretrizes para a regulamentação das areeiras, condicionadas à execução de medidas de recuperação por parte das empresas (Resolução SMA 42/96).

Após a promulgação das Constituições Federal e estaduais, os municípios também passaram a incorporar aspectos de recuperação nos seus quadros legais, alguns dos quais incluindo o tema em suas leis orgânicas. As formas possíveis de tratamento da questão de explotação dos recursos naturais por parte das prefeituras municipais, indicam que o assunto pode ser previsto nos instrumentos de planejamento e gestão existentes, como o Plano Diretor e a Lei de Uso e Ocupação do Solo. Como exemplo, o primeiro pode identificar as áreas de degradação ambiental do município e propor programas de recuperação, enquanto o segundo pode contemplar, entre as sanções civis e administrativas para os casos de descumprimento, a exigência de recuperação da área degradada (CENTRO DE ESTUDOS E PESQUISAS EM ADMINISTRAÇÃO MUNICIPAL- CEPAM, 1991).

Quanto aos mecanismos que permitem assegurar a disponibilidade e alocação de recursos financeiros na recuperação de áreas degradadas por mineração, não há no País nada similar aos de países desenvolvidos, como, por exemplo, o do "Superfund" dos EUA ou do sistema de caução da província de Ontário, Canadá. Contudo, a legislação que institui a compensação financeira para os estados e municípios pelo resultado do aproveitamento de recursos minerais em seus territórios (Lei Federal 7.990/89), gera, indiretamente, essa possibilidade. No caso dos bens minerais comumente lavrados na RMSP, a alíquota para cálculo da compensação por parte das empresas de mineração é de 2\% (Lei Federal 8.001/90). 
Em seu regulamento (Decreto Federal 1/91), a legislação prevê que a distribuição da compensação financeira destine $23 \%$ aos estados, $65 \%$ aos municípios e $12 \%$ ao DNPM, sendo que este último "destinará $2 \%$ à proteção ambiental nas regiões mineradoras, por intermédio do Ibama" (Artigo $2^{\circ}$, paragrafo $2^{\circ}$, inciso III).

Ainda na busca de instrumentos que auxiliem na recuperação efetiva de áreas degradadas, a Secretaria de Estado do Meio Ambiente-SMA, São Paulo, editou a Resolução SMA 5/97, criando a figura jurídica do Termo de Compromisso de Ajustamento de Conduta. O Termo, com força de título executivo extrajudicial, é amparado na Lei da Ação Civil Pública (Lei Federal 7.347/85), modificada pelo Código de Defesa do Consumidor (Lei Federal 8.078/90). O Termo, como diz o nome, visa ajustar a conduta de infratores às exigências legais. As condutas de que trata a Resolução fazem parte das violações aos chamados direitos difusos, direitos coletivos e direitos individuais homogêneos, conforme definidos no Código de Defesa do Consumidor (Artigo 81, Parágrafo único, incisos I, II e III). Objetiva, ainda, instrumentalizar a administração pública competente para fixar as obrigações e condicionantes técnicas, bem como os prazos que deverão ser cumpridos pelos responsáveis para corrigir a degradação ambiental. A Resolução determina que a Companhia de Tecnologia de Saneamento AmbientalCetesb e a Fundação para a Conservação e a Produção Florestal- Fundação Florestal adotem - Termo, "de modo a cessar, adaptar, recompor, corrigir ou minimizar os efeitos negativos da atividade degradadora em relação ao meio ambiente" (Artigo $2^{\circ}$ ). Em seu anexo, a Resolução apresenta um modelo de Termo, explicitando-o como um tipo de contrato a ser estabelecido e firmado de comum acordo entre o responsável pela degradação ambiental, denominada de devedora ambiental e o órgão público, denominado de autoridade ambiental. Dada sua recente edição, não há, ainda, casos em que o Termo tenha sido aplicado.

\subsubsection{Gestão metropolitana}

Em âmbito metropolitano, o tema da recuperação foi inicialmente contemplado na RMSP através do Convênio firmado em 1976 entre a então Secretaria de Estado dos Negócios Metropolitanos- SNM e o DNPM. O Convênio previa que todos os pedidos de pesquisa ou lavra apresentados ao DNPM, inclusive os de renovação, estariam sujeitos à análise e parecer da SNM. O objetivo era de compatibilizar a atividade mineral com o uso do solo, em conformidade com as diretrizes de planejamento metropolitano.

Assim, regulamentaram-se os procedimentos para a obtenção do parecer da SNM (Resolução SNM 03/77), exigindo-se, entre outros documentos, a apresentação de um Projeto de Recuperação do Solo tratando "inclusive da cobertura vegetal, contendo estudo das medidas visando à recuperação do solo, pelo interessado, simultaneamente à exploração 
mineral, de forma a possibilitar outros tipos de uso do solo recuperado..." (SÃO PAULO, 1982, p.49).

No âmbito do Convênio entre a SNM e o DNPM, elaborou-se o Plano Diretor de Mineração- PDM da RMSP. O produto principal é o mapa de diretrizes para a atividade mineral ou zoneamento mineral, em que a mineração poderia ser classificada em uma das quatro categorias: permitida sem restrições de ordem externa; permitida com restrições de ordem externa; não permitida; e caso especial (SÃO PAULO, 1980). A definição das categorias diz respeito à legislação de proteção aos mananciais (Lei Estadual 898/75 e 1.172/76 e Decreto Estadual 97.14/77), legislação de zoneamento industrial (Lei Estadual 1.817/78 e Decreto Estadual 13.005/79), além de outros concernentes à proteção ecológica (matas, várzeas, nascentes e declividades acima de 30\%), acervo cultural (dentro e fora da mancha urbana), urbanização (imediata e futura) e produção rural (com e sem irrigação).

Dentre os trabalhos conduzidos com o objetivo de implementar as diretrizes e recomendações do Plano Diretor de Mineração, foram elaborados três projetos básicos para a recuperação de áreas degradadas em minas abandonadas, sob patrocínio da SNM: pedreira em Itapevi, areia em Embu e cascalho em Franco da Rocha. No caso de Itapevi, elaborou-se o projeto executivo com vistas à construção de um anfiteatro aberto destinado àapresentação de eventos culturais (LEONARDI et al., 1984; EMPLASA, 1989b). No entanto, nenhum dos projetos foi realizado.

No período de 1980 a 1990, as atividades do Convênio entre a SNM e o DNPM e a aplicação do Plano Diretor de Mineração da RMSP contemplaram, entre as principais linhas de trabalho, o acompanhamento da recuperação efetuada pelas empresas concomitantemente às atividades de mineração (SAVASTANO NETO et al., 1991). Data de 1985 a organização das primeiras equipes de fiscalização na áreas de mananciais, através da Emplasa/SNM. No início dos anos 90 a vigência do Convênio expirou, não tendo sido renovado desde então.

Em 1993, a atribuição para a aplicação da legislação sobre a Área de Proteção aos Mananciais na RMSP foi transferida da então SNM (atual Secretaria da Habitação e Desenvolvimento Urbano- SHDU) para o Departamento de Uso do Solo Metropolitano- DUSM da Secretaria de Estado do Meio Ambiente- SMA.

A criação de um "balcão único" pelo Poder Público estadual (Resolução SMA 35/96), com o objetivo de agilizar e integrar as diversas licenças ambientais expedidas pelos órgãos do Estado na RMSP (Cetesb, DUSM, Daia e DEPRN), também contempla os aspectos de recuperação incluídos nos diferentes documentos técnicos que instruem os pedidos de licenciamento efetuados para empreendimentos mineiros.

Outras metrópoles brasileiras também têm promovido estudos de planejamento com vistas à compatibilização das atividades de mineração com o uso do solo e a proteção 
ambiental. No caso do Rio de Janeiro, FUJIMURA et al. (1984) sintetizam diversos estudos executados desde 1979 com o objetivo de promover a relocação de pedreiras.

A realização de experiências semelhantes à da RMSP em Salvador, Recife e Belo Horizonte, foi definida como uma das diretrizes políticas do DNPM no início dos anos 90 (MACHADO, 1991). Em Salvador, os trabalhos levaram à formulação do Plano Diretor de Mineração com produtos similares aos da RMSP (DNPM, 1992). O mesmo caminho é perseguido no caso de Belo Horizonte (MASCARENHAS, OLIVEIRA, 1992).

Estudos da Companhia de Pesquisa de Recursos Minerais- CPRM, empresa do Ministério das Minas e Energia, denominada Serviço Geológico do Brasil, vem sendo realizados desde o início da década de 90 em algumas metrópoles e grandes cidades do País, como Curitiba, Porto Alegre, Belo Horizonte, Recife, Belém, Fortaleza, Manaus e Porto Velho, contemplando a perspectiva de gerar subsídios para a formulação de planos diretores. $\mathrm{Na}$ região de Porto Alegre, por exemplo, a dimensão dos problemas ambientais tem atingido níveis expressivos, como os decorrentes da lavra de arenitos da Formação Botucatu em 46 pedreiras instaladas no Morro de Paula, município de São Leopoldo, cujos conflitos levaram os órgãos públicos municipais, estaduais e federais àformulação de um plano de desativação progressiva da atividade extrativa (COLLAÇO et al., 1995)

O município de São Paulo, que em 1989 abrigava o maior número de minas em atividade na RMSP (cerca de 20\% do total), prevê em sua lei orgânica de 1990 que o causador de danos ambientais deve "promover a recuperação plena do meio ambiente" (Artigo 183, caput). Os procedimentos têm sido regulamentados pela Secretaria das Administrações Regionas- SAR, no âmbito do Termo de Obras e Serviços, que deve conter o "registro dos compromissos assumidos pelo minerador, proveniente do consenso entre as partes ou por determinação do poder público" (Portaria SAR 1.631/95, anexo I, parte C, item 1.3).

A regulamentação do tema na cidade de São Paulo menciona diversos exemplos de medidas que devem constar do Termo, como correção da inclinação dos taludes, correção e prevenção da erosão, recomposição topográfica, barragens, diques de contenção e extravasores, sistemas de drenagem, armazenamento da camada fértil de solo, revegetação, umedecimento de vias, entre outros. A execução dos trabalhos é atribuída a um grupo especialmente dedicado a esta finalidade, denominado Grupo de Controle de Mineração, criado pela Portaria SAR 326/92 e que tem propiciado um envolvimento crescente da Prefeitura do Município de São Paulo na questão (SILVA et al., 1993).

O disciplinamento das movimentações de terra, prevenção e correção da erosão, o que inclui a atividade mineral, foram objeto de legislação na cidade de São Paulo (Lei Municipal 11.380/93). Embora ainda sem regulamentação, a Lei inova ao estabelecer obrigatoriedade aos proprietários para que preservem ou recuperem os terrenos sujeitos àerosão. 


\subsubsection{Participação da comunidade}

A participação da comunidade nos procedimentos relacionados à recuperação de áreas degradadas no País tem sido restrita. O advento da legislação que instituiu a defesa dos interesses difusos no País e disciplinou a ação civil pública de responsabilidade por danos causados ao meio ambiente (Lei Federal 7.347/85), atribuindo ao Ministério Público- MP federal ou estadual a função de "advogado da sociedade", propiciou um certo nível de participação. A atuação do Ministério Público tem ocorrido por meio das curadorias de meio ambiente, seja através de inquéritos civis conduzidos na esfera da administração pública, seja por meio de ações civis públicas na esfera jurídica, podendo ser de caráter preventivo (ação cautelar) ou corretivo (exigência de reparação do dano). Desde então, a partir de solicitações da comunidade, o Ministério Público em SP tem sido envolvido em inúmeros casos de mineração, principalmente em extrações de areia para construção civil em leito de rio.

No entanto, a participação institucionalizada das comunidades potencialmente afetadas pela degradação, somente tem sido possível através dos procedimentos de avaliação de impacto ambiental- AIA, em que os empreendimentos apresentam seu Prad no âmbito de EIA/Rima. Essa participação tende a ocorrer por meio das audiências públicas que são convocadas e realizadas durante o processo de análise do EIA/Rima por parte do órgão ambiental, como ocorreu no projeto de ampliação da mina de fosfato da Arafértil, em Araxá, $M G$, cujo resultado propiciou a recuperação de áreas anteriormente degradadas. Convém salientar que essas audiências somente se realizam quando solicitadas pela comunidade, 0 que revela uma atitude predominantemente reativa por parte do Poder Público em auscultar os interessados.

Porém, a decisão sobre o uso futuro de áreas de mineração no País tem sido geralmente tomada de maneira unilateral, por parte da empresa de mineração ou do proprietário do solo, raramente envolvendo a comunidade. Pouca diferença tem feito o fato de que no País a legislação faz a distinção entre a propriedade do solo e do subsolo.

Por outro lado, a decisão vem se tornando cada vez mais pública no País, sem deixar de ser também privada, o que exige comunicação e negociação, eventualmente recorrendo à mediação de conflitos. Elencam-se algumas técnicas de comunicação com o público que poderiam ser implementadas (como audiências públicas, reuniões públicas, reuniões com pequenos grupos, seminários, visitas de campo "portas abertas", prospectos de informação, "press releases", mala direta solicitando comentários, comitês consultivos), bem como princípios para construção de consenso (SÁNCHEZ, 1995). 
A aplicação da negociação é exemplificada em um caso de conflitos ambientais no município de São Paulo, envolvendo a Pedreira Itaquera e a comunidade vizinha composta pelos 65.000 moradores de um grande conjunto habitacional denominado Cohab I (SÁNCHEZ et al., 1993; ALEXANDRIA, 1995). Gerados principalmente pelas vibrações e sobrepressão do ar resultantes do desmonte rochoso com uso de explosivos, os conflitos na Pedreira Itaquera começaram a ser minimizados quando a equipe encarregada da elaboração do Prad sugeriu à empresa mineradora a consulta à comunidade. A partir de então, estabeleceu-se um processo de negociação, conduzido por meio de técnicas de mediação, que assegurou àcomunidade a informação sobre a tecnologia utilizada e permitiu abrir um canal de diálogo e a conseqüente redução do conflito. A negociação resultou em um acordo firmado entre a empresa e a comunidade que incluiu a revisão do plano de fogo, plantio de barreira vegetal entre a pedreira e a vizinhança e o estabelecimento de medidas compensatórias (doação periódica de blocos de concreto e empréstimo de equipamentos para obras comunitárias). No processo, a comunidade se fez representar por um conselho constituído especialmente para o caso (Conselho de Entidades da Cohab I), representando cerca de vinte associações e grupos de moradores da região. Os aspectos de utilização das áreas degradadas neste mesmo caso foram abordados por IBRAHIM (1996).

\subsection{Gerenciamento empresarial}

Com o advento da normalização técnica internacional relacionada a sistemas de gestão ambiental em nível empresarial, por meio da Internacional Organization for StandardizationISO (ISO, 1994), tem sido crescente a inclusão da recuperação de áreas degradadas como um dos instrumentos de gerenciamento ambiental aplicáveis à indústria de mineração (SÁNCHEZ, 1992b).

A aplicação de EIA/Rima e auditoria ambiental como instrumentos de gerenciamento ambiental, respectivamente aos casos da mineração de areia Floresta Negra em Guarulhos, SP e da mineração de amianto da Sama em Minaçu, GO, são discutidos por FORNASARI FILHO (1995) com ênfase no estudo de processos do meio físico e incorporando aspectos de controle e estabilização de áreas degradadas. Sugere um roteiro metodológico para estudo de alterações no meio físico aplicável aos instrumentos de gerenciamento ambiental de empreendimentos mineiros. Estudos específicos sobre auditoria ambiental no mesmo caso da Sama, contemplam aspectos de recuperação e indicam procedimentos aplicáveis a outros tipos de mineração (BRAGA et al., 1996).

Estudo comparativo entre empreendimentos que utilizam diferentes instrumentos de gerenciamento ambiental, revela a freqüência da recuperação de áreas degradadas, como 
efetuado por PARIZOTTO (1995) em cinco casos de empreendimentos mineiros (ouro da Rio Paracatu Mineração S.A., no Morro do Ouro, Paracatu, MG; carbonatito da Serrana S.A. de Mineração Ltda., no Morro da Mina, Cajati, SP; pirocloro da Companhia Brasileira de Metalurgia e Mineração- CBMM, em Araxá, MG; apatita da Arafértil S.A., na mina de Barreiro, em Araxá, MG; e ferro da Minerações Brasileiras Reunidas- MBR S.A., nas minas de Águas Claras, Mutuca e Pico de Itabira, em Nova Lima e Itabira, MG). Mostra que a recuperação de áreas degradadas está, juntamente com o monitoramento ambiental, entre os instrumentos de gerenciamento ambiental mais utilizados pelas empresas de mineração, sendo adotado por todas. Contudo, observa que o fato é explicado pela obrigatoriedade legal da recuperação e que outros instrumentos, como a avaliação de impacto ambiental, não são tão utilizados pois muitas empresas são anteriores àlegislação ambiental sobre o tema.

CASSIANO, CAVALCANTI (1996) adotam o método comparativo utilizado por PARIZOTTO (1995), entre o mesmo caso da RPM em Paracatu, MG, e outro de ouro da CVRD na mina da Fazenda Brasileiro em Teofilândia, BA, identificando a recuperação de áreas degradadas como um dos instrumentos de gerenciamento ambiental utilizado pelas empresas e avaliando o resultado das medidas efetuadas. Ao final, reconhecem um melhor desempenho ambiental no caso da RPM.

\subsection{Etapas e procedimentos aplicáveis à RMSP}

Considerando os variados aspectos envolvidos na recuperação de áreas degradadas por mineração, particularmente os que se aplicam ao contexto urbano, pode-se elencar as etapas e procedimentos básicos que devem orientar os trabalhos no caso de empreendimentos na RMSP (FIGURA 3.1).

Contemplam-se as ações que devem ser realizadas pelo empreendedor, seja empresa de mineração no caso de minas ativas, seja de outro setor social ou econômico no caso de projetos de reabilitação em minas dasativadas ou áreas abandonadas. O ponto de partida é o compromisso indispensável do empreendedor com a recuperação, caso contrário as etapas e procedimentos subseqüentes têm maiores riscos ou possibilidades de interrupção ou mesmo de mudanças incompatíveis com os objetivos ambientais previamente estabelecidos. $O$ compromisso do empreendedor deve incluir o equacionamento prévio dos recursos financeiros que serão destinados para garantir a execução da recuperação.

Incluem-se, entre as ações de planejamento que envolvem o empreendedor, uma adequada e cuidadosa avaliação da degradação instalada. Além disso, há a necessária participação da comunidade direta ou indiretamente afetada e dos órgãos ambientais encarregados legalmente da análise, aprovação e controle da recuperação. 
O elemento central na seqüência de etapas e procedimentos tende a ser o plano de recuperação. O plano deve desempenhar, ao mesmo tempo, o papel de instrumento de planejamento e de negociação, sendo potencialmente capaz de integrar e compatibilizar, durante os procedimentos de elaboração e análise, soluções que atendam as intenções do empreendedor, as preocupações da comunidade e as atribuições dos órgãos públicos envolvidos, sejam estes federais, estaduais ou municipais.

Como se verifica em países nos quais a consulta pública e a participação da comunidade no processo de elaboração e aprovação do plano é assegurada legalmente, os aspectos principais no processo de planejamento tende a ser a definição dos objetivos da recuperação, o que compreende medidas de estabilização e a questão do uso futuro da área.

A aprovação do plano deve propiciar a implementação das medidas planejadas, incluindo as que se destinam à instalação do uso futuro da área. A execução do plano e as ações de monitoramento e manutenção das medidas de recuperação, pressupõem 0 acompanhamento por parte da comunidade e dos órgãos públicos até a consolidação do uso do solo pós-mineração. 
ETAPAS

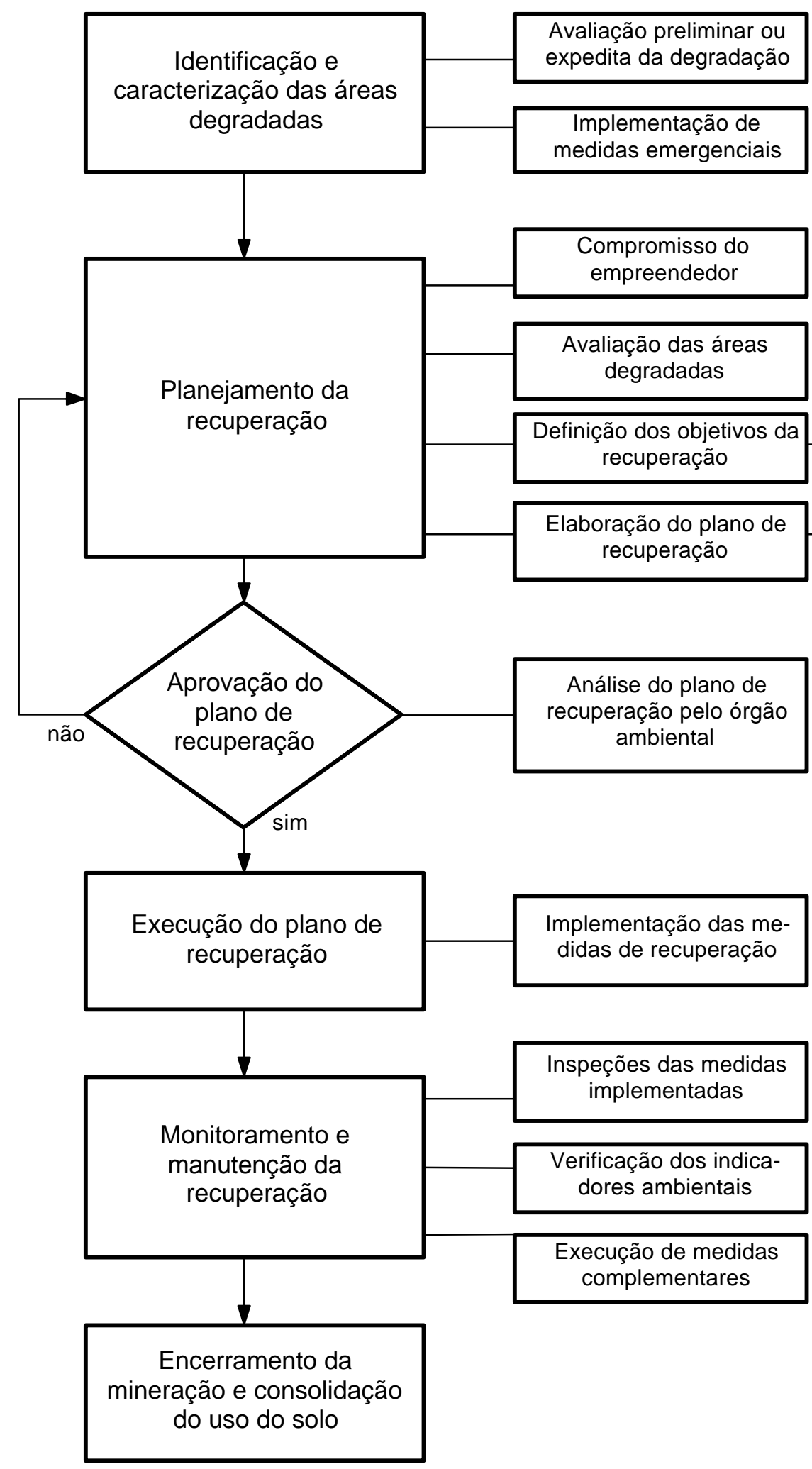

PROCEDIMENTOS BÁSICOS

FIGURA 3.1- Etapas e procedimentos básicos na recuperação de áreas degradadas por mineração, considerando empreendimentos instalados em regiões urbanas. 


\section{CAPÍTULO 4}

\section{PLANEJAMENTO DA RECUPERAÇÃO NA RMSP}

Este Capítulo apresenta e discute os resultados da avaliação dos procedimentos relacionados ao planejamento da recuperação de áreas degradadas por mineração na RMSP, tendo como referência o conteúdo de Planos de Recuperação de Áreas Degradadas- Prads elaborados pelas empresas e submetidos àanálise e aprovação dos órgãos ambientais.

Os Prads constituem a explicitação formal das propostas de soluções técnicas de recuperação definidas pelas empresas de mineração, conforme estabelece a legislação vigente, sendo, portanto, elementos básicos para uma avaliação dos aspectos principais relativos ao planejamento da recuperação.

\subsection{Planos de recuperação}

A partir de 1989, ano em que se iniciaram os procedimentos legais e formais para elaboração e aprovação de Prads no País, as empresas de mineração começaram a encaminhar aos órgãos ambientais de SP suas propostas de soluções técnicas para recuperação das áreas degradadas. Desde então, os Prads têm sido elaborados principalmente por empresas privadas de consultoria e projetos ou por profissionais autônomos, especialmente das áreas de geologia e de engenharia de minas.

Inicialmente, sobretudo nos dois anos subseqüentes, a apresentação dos Prads de mineração em SP ocorreu especialmente por meio de documentos específicos e individualizados (Prads, propriamente ditos), encaminhados ao órgão ambiental encarregado da análise (Secretaria de Estado do Meio Ambiente- SMA).

Com o tempo, em face das imposições e alterações decorrentes das sucessivas mudanças e atualizações da legislação, os Prads passaram a ser incorporados aos procedimentos normais de licenciamento ambiental, sendo incluídos em Estudo de Impacto Ambiental e Relatório de Impacto Ambiental- EIA/Rima de novos empreendimentos. No caso de minerações não sujeitas ou mesmo dispensadas do processo de avaliação de impacto ambiental, o plano de recuperação passou a ser incluído em documentos técnicos relativamente mais simples, denominados de Plano de Controle Ambiental- PCA ou Relatório de Controle Ambiental- RCA.

Há uma diferença entre os dois períodos, visto que os Prads apresentados de modo individualizado evidenciam especialmente as proposições iniciais do empreendedor, enquanto os que tramitam em meio a outros documentos exigidos nos procedimentos de licenciamento 
ambiental (EIA/Rima, PCA ou RCA), tendem a refletir o resultado da interação com os diversos órgãos da SMA envolvidos no processo de análise (Departamento de Avaliação de Impacto Ambiental- Daia e, de modo, complementar, a Companhia de Tecnologia de Saneamento Ambiental- Cetesb, Departamento de Proteção de Recursos Naturais- DEPRN- neste, às vezes com o envolvimento do Ibama- e Departamento de Uso do Solo Metropolitano- DUSM) e, dependendo do caso, também com a comunidade.

Breve consulta à listagem dos Prads protocolizados no Daia/SMA permite a identificação de 102 documentos referentes a empreendimentos localizados na RMSP, todos elaborados e apresentados isoladamente, ou seja, na forma de documentos individualizados (TABELA 4.1).

TABELA 4.1- Número de Prads relativos à RMSP, segundo o bem mineral e a situação da mina.

\begin{tabular}{|c|c|c|c|}
\hline \multirow[b]{2}{*}{ Bem mineral } & \multicolumn{2}{|c|}{ Situação } & \multirow[b]{2}{*}{ Total } \\
\hline & $\begin{array}{l}\text { Minas } \\
\text { ativas }\end{array}$ & $\begin{array}{c}\text { Minas } \\
\text { desativadas } \\
\left(^{\star}\right)\end{array}$ & \\
\hline Areia (às vezes com lavra secundária de argila, brita ou caulim) & 28 & 08 & 36 \\
\hline Brita (às vezes com lavra secundária de areia para construção) & 19 & 06 & 25 \\
\hline Argila (æ̀s vezes com lavra secundária de areia para construção) & 06 & 09 & 15 \\
\hline Quartzito & 07 & 06 & 13 \\
\hline Calcário & 04 & 03 & 07 \\
\hline Caulim (às vezes com lavra secundária de areia para construção) & 01 & 02 & 03 \\
\hline Filito & - & 02 & 02 \\
\hline Feldspato & 01 & - & 01 \\
\hline Total & 66 & 36 & 102 \\
\hline
\end{tabular}

Fonte: Daia/SMA, junho de 1995.

$\left({ }^{*}\right)$ inclui os Prads que não mencionam a situação da mina.

Considerando o total de 463 áreas de mineração (ativas, paralisadas e abandonadas) existentes na RMSP, segundo o cadastro de referência (EMPLASA, 1989b), apenas cerca de $22 \%$ apresentaram Prad ao órgão ambiental e o fizeram de modo individualizado.

Dentre esses Prads, cerca de $2 / 3$ corresponde a minerações que se encontram em plena atividade na metrópole, sendo o outro $1 / 3$ composto de minas desativadas. Têm sido raros os casos de Prads de novos empreendimentos, ou seja, de minerações que pretendem se instalar na RMSP. Estes empreendimentos teriam seu plano de recuperação incluído em EIA/Rima, PCA ou RCA e, por isso, não estão incluídos na listagem do Daia/SMA. 


\subsection{Objetivos da recuperação}

Analisando o conteúdo de 91 dos 102 Prads de minas ativas e desativadas situadas na RMSP, verifica-se que a maior parte segue o Roteiro estabelecido pela legislação estadual em 1989.

Os Prads de minas ativas contém, entre outras informações solicitadas, as medidas a serem implementadas durante o desenvolvimento da atividade extrativa e as propostas ou possibilidades de usos pós-mineração para as áreas degradadas. Na maior parte, as medidas de recuperação propostas estão desvinculadas dos usos pós-mineração, ou seja, não contemplam a perspectiva de realizar a reabilitação concomitantemente æ̀s atividades de mineração. Visa-se, primordialmente, a estabilidade do ambiente, deixando em segundo plano as medidas diretamente relacionadas com o uso futuro.

Assim, os planos de recuperação de minas ativas explicitam dois objetivos fundamentais: a estabilização das áreas degradadas por meio de medidas executadas a curto e médio prazo e o estabelecimento do uso pós-mineração a longo prazo. No entanto, a quase totalidade dos Prads deixa de expressar a dimensão da área a ser recuperada, seja de forma quantitativa ou ilustrativa mediante anexação de croquis, figuras ou fotos. Do mesmo modo, são poucos os Prads de minas ativas que apresentam os custos de recuperação, bem como os que demonstram ter um cronograma para a execução dos trabalhos ou ao menos um prazo para sua conclusão.

Os Prads de minas desativadas, por sua vez, priorizam as medidas que visam alcançar o uso pós-mineração a curto prazo, sendo comumente mencionadas: regularização ou recomposição da morfologia do terreno por meio de terraplenagem, incluindo a remobilização de depósitos de estéreis (bota-foras); e revegetação baseada no plantio predominante de espécies nativas, em que é freqüentemente citada a intenção de restituir a flora ciliar de rios e córregos próximos e implantá-la nas margens de lagos remanescentes da atividade mineral. Estes planos geralmente explicitam a dimensão da área a ser recuperada (em ha), o prazo (variável de acordo com cada mina desativada, mas comumente situado entre 2 a 6 anos) e uma estimativa dos custos de recuperação.

Tanto em Prads de minas ativas como de desativadas, são raras as evidências de que tenham sido elaborados com algum nível de participação da comunidade no processo de planejamento. Em geral, os planos expressam medidas estabelecidas exclusivamente pelo empreendedor e sequer exprimem iniciativas de comunicação com a comunidade circunvizinha ou mesmo com os órgãos públicos. 


\subsubsection{Medidas de recuperação propostas}

As medidas de recuperação de áreas degradadas descritas nos Prads consultados, apresentam uma ampla variedade de possibilidades. Em geral, é notável o domínio de medidas que expressam a conjugação de técnicas de revegetação com procedimentos de natureza geotécnica. Medidas de remediação são raras e aparecem apenas nos Prads de minas ativas.

A revegetação prevista nos Prads de minas ativas é caracterizada principalmente pelo plantio manual de mudas de espécies herbáceas e arbóreas, exóticas ou nativas, æ̀s vezes precedido da retirada, armazenamento e colocação do solo superficial orgânico proveniente do decapeamento. Prevê-se também a instalação de barreiras vegetais e, com muita freqüência nos casos de mineração de areia e argila em planícies aluvionares, a revegetação ciliar ao longo dos principais cursos d'água que percorrem a área do empreendimento. A semeadura manual de gramíneas é prevista na cobertura de áreas terraplenadas.

As medidas geotécnicas citadas visam principalmente a contenção ou retenção de sedimentos e a atenuação dos impactos visuais. Compreendem principalmente o remodelamento topográfico, com o aproveitamento de estéril no preenchimento de cavas, combate à erosão e assoreamento, retaludamento e estabilização de encostas e frentes de lavra, construção e ampliação de barragens, descompactação do solo em áreas de infraestrutura e instalação de sistemas de drenagem.

Medidas de remediação são mencionadas apenas em Prads de minas ativas, sendo lembradas no tratamento de efluentes líquidos provenientes de oficinas de manutenção de máquinas e equipamentos, na instalação de caixas de retenção e coleta de óleos e graxas e, às vezes, na coleta e disposição de resíduos sólidos. Poucas medidas se referem ao processo de beneficiamento.

\subsubsection{Previsão de usos pós-mineração}

Os 91 Prads consultados fornecem um panorama sobre os diferentes tipos de usos pósmineração previstos e citados pelas empresas de mineração na RMSP. Dada a diversidade de tipos citados, pode-se agrupar os diferentes usos mencionados de acordo com a similaridade de funções sociais, econômicas ou ambientais pretendidas, sejam públicas ou privadas (TABELA 4.2).

TABELA 4.2- Usos pós-mineração previstos em Prads $\left({ }^{*}\right)$ na RMSP.

Quantidade de citações (\%) 


\begin{tabular}{l|c|c}
\cline { 2 - 3 } & indefinido & indefinido \\
\hline Lazer, recreação, esportes comunitários & 19 & 19 \\
\hline Preservação ou conservação ambiental & 13 & 22 \\
\hline Indústria ou comércio & 11 & 17 \\
\hline Pastagem, horticultura, atividades agrícolas & 07 & 07 \\
\hline Habitação, loteamento & 03 & 10 \\
\hline Reflorestamento comercial & 02 & 01 \\
\hline Piscicultura, pesca & 01 & 03 \\
\hline Aeroclube & 01 & 01 \\
\hline Hotelaria & 01 & 01 \\
\hline Chácara de lazer & 01 & 01 \\
\hline Campo de golfe & 01 & 01 \\
\hline Disposição de resíduos, tratamento de esgotos & - & 04 \\
\hline Manancial hídrico para abastecimento & - & 03 \\
\hline Indefinido (**) & 25 & - \\
\hline Ausente (*** & 100 & 11 \\
\hline Font: Daia/SM, jun & & \\
\hline
\end{tabular}

Fonte: Daia/SMA, junho de 1995.

$\left({ }^{*}\right)$ Em um total de 91 Prads consultados e 160 citações de uso pós-mineração.

$\left.{ }^{* *}\right)$ Imprecisão na citação de uso pós-mineração, contendo diversas alternativas.

$\left(^{* * *}\right)$ Ausência de citação de uso pós-mineração.

Alguns Prads contemplam, em um mesmo documento técnico, mais de uma alternativa de uso pós-mineração, enquanto outros se referem a mais de uma área degradada. Por isto, o número total de citações de usos pós-mineração nos 91 Prads consultados é de 160. Desconsiderando as citações dos 25 indefinidos e dos 18 que não mencionam qualquer tipo de uso, portanto classificados como ausentes, tem-se uma média de 3 citações de diferentes usos para cada Prad.

No que se refere aos tipos de usos pós-mineração citados, apenas $57 \%$ dos Prads estabelecem a opção por uma única alternativa. A preferência é principalmente por áreas de lazer, recreação, esportes comunitários, preservação ou conservação ambiental e construção industrial e comercial. Juntos, estes usos respondem por cerca de metade do número total de citações. Os demais Prads (43\%) não indicam qualquer tipo de uso ou o fazem de forma extremamente genérica e imprecisa. Os Prads com uso indefinido se caracterizam pela 
quantidade e diversidade de alternativas de uso pós-mineração propostas para uma mesma área, muitas delas provavelmente incompatíveis entre si, como construção industrial e unidade de conservação ambiental, o que ilustra o grau de indefinição sobre o uso futuro da área.

Esses dados conduzem àobservação geral de que há um certo equilíbrio entre o número de empreendimentos que possuem uma definição explícita em relação ao uso futuro da área e os que não o fazem, com pequena margem superior para os primeiros.

Dentre os diferentes tipos de usos pós-mineração mencionados nos Prads indefinidos, ressaltam-se as citações de alternativas não priorizadas nos definidos. Este é o caso, por exemplo, de disposição de resíduos, tratamento de esgotos e manancial para abastecimento público, alternativas cuja instalação geralmente exige o envolvimento e anuência do Poder Público e dificilmente podem ser assumidas como opção unilateral do empreendedor.

Entre os argumentos mais utilizados nos Prads para justificar as indefinições de usos pós-mineração, além de incertezas sobre a propriedade legal do solo e insegurança quanto às mudanças da legislação ambiental, destaca-se o longo tempo de vida útil do empreendimento. Incluem-se, neste último, as incertezas de mercado em face da dimensão conhecida da jazida. Admitindo, em função das características da mineração na RMSP, uma vida útil inferior a 5 anos como sendo de curto prazo, entre 5 e 15 anos como de médio prazo e superior a 15 anos como de longo prazo e, ainda, considerando apenas os Prads que indicam uma estimativa de vida útil, pode-se estabelecer uma relação direta com o caráter de definição do uso pósmineração (TABELA 4.3).

TABELA 4.3- Número de Prads, segundo a vida útil do empreendimento e o caráter de definição do uso pós-mineração.

\begin{tabular}{|c|c|c|c|}
\hline \multirow{2}{*}{$\begin{array}{l}\text { Caráter de definição } \\
\text { do uso } \\
\text { pós-mineração }\end{array}$} & \multicolumn{3}{|c|}{ Quantidade de Prads (\%) } \\
\hline & Curto prazo ( $<5$ anos) & Médio prazo (5 a 15 anos) & Longo prazo (> 15 anos) \\
\hline Definido & 04 & 18 & 51 \\
\hline Indefinido & 01 & 10 & 15 \\
\hline Ausente & - & - & 01 \\
\hline Total & 05 & 28 & 67 \\
\hline
\end{tabular}

Assim, ao contrário do que mencionam os planos com uso indefinido, a maior parte dos Prads que apresentam uma definição explícita sobre o uso pós-mineração coincide com os que indicam vida útil de longo prazo. Isto induz àconclusão de que o planejamento do uso futuro da 
área tende a ser melhor estabelecido nos empreendimentos que têm expectativas de vida útil de longo prazo, ainda que, com o tempo, possa ser atualizado ou modificado.

Convém salientar que os dados obtidos acerca da propriedade do solo, embora incertos quanto à posse legal dos terrenos, indicam que a maior parte das empresas tem o controle efetivo da terra, seja por propriedade ou por arrendamento a longo prazo, o que, a rigor, deveria dar maior segurança e tranquilidade para planejar o futuro.

Por outro lado, a compatibilidade entre os diferentes tipos de uso pós-mineração previstos nos Prads e as características ambientais e culturais da circunvizinhança tende a ser viável, sobretudo em face da diversidade de formas de uso existentes no contexto complexo de ocupação territorial da RMSP. Não há nenhum tipo de citação de uso do solo inédito na metrópole e, em princípio, todos os tipos de uso do solo propostos podem ser alcançados. 


\section{CAPÍTULO 5}

\section{MEDIDAS DE RECUPERAÇÃO EM MINAS ATIVAS NA RMSP}

Este Capítulo apresenta os resultados da avaliação das medidas de recuperação de áreas degradadas por mineração praticadas em minas ativas na RMSP, tendo como referência os 42 empreendimentos levantados e estudados (TABELA 5.1 e FIGURA 5.1).

TABELA 5.1- Relação das minas ativas estudadas.

\begin{tabular}{|c|c|c|}
\hline Código & Empreendimento & Localização \\
\hline AG-01 & Mineração Horboy Clays & Estr. Mogi das Cruzes-Salesópolis km 75, Faz. Velha- Biritiba Mirim \\
\hline AG-05 & Empresa de Mineração Lopes & Estr. Mogi das Cruzes-Salesópolis km 67, Bairro Irohy- Biritiba Mirim \\
\hline AG-06 & Empresa de Mineração Baruel & Estr. da Lagoinha s/n- Salesópolis \\
\hline AR-01 & Mineração Caravelas & R. Caravelas s/n, Brás Cubas- Mogi das Cruzes \\
\hline AR-02 & Cemica Mineração & Estr. Mogi das Cruzes-Salesópolis km 17, Faz. Irohy- Biritiba Mirim \\
\hline AR-03 & Mineradora RAF & Av. Marginal Esquerda 751, Tamboré- Barueri \\
\hline$\overline{\mathrm{AR}-04}$ & Indústria Extrativa Santos & Sítio Mutinga, Aldeia de Barueri- Barueri \\
\hline AR-05 & Empresa de Mineração Brejão & Sítio Mutinga- Barueri \\
\hline$\overline{A R-07}$ & Mineração Viterbo Machado Luz & Estr. da Varginha km $5 \mathrm{~s} / \mathrm{n}$, Parelheiros- São Paulo \\
\hline AR-08 & Itaquareia & R. Rio Paraná 155- Itaquaquecetuba \\
\hline AR-09 & Sarp Extração de Areia & Estr. da Pedreira 970- Barueri \\
\hline AR-15 & Empr. de Mineração Floresta Negra & Estr. da Parteira 3.000, Nova Bonsucesso- Guarulhos \\
\hline AR-18 & Lauro Pavan e Cia. & Estr da Varginha s/n, Parelheiros- São Paulo \\
\hline AR-19 & Mineração de Areia Baronesa & Estr. da Cumbica 410, Santo Amaro- São Paulo \\
\hline$\overline{\mathrm{AR}-24}$ & Porto de Areia Paineiras & R. Padre Azevedo s/n, Parelheiros- São Paulo. \\
\hline$\overline{\mathrm{AR}-25}$ & João Carlos Pongiluppi & Estrada da Varginha s/n, Parelheiros- São Paulo \\
\hline AR-26 & Ponte Alta Extração de Areia & Estr. da Ponte Alta, 10.000, Cipó- São Paulo \\
\hline AR-34 & Porto de Areia Sete Praias & R. Josefina Gianini Elias 499, Santo Amaro- São Paulo \\
\hline BT-01 & Sarpav Mineradora & Estr. da Pedreira 970- Barueri \\
\hline$\overline{B T-02}$ & Pedreira Embu & Estr. do DAEE km 30- Embu \\
\hline BT-08 & Pedreira Firpavi & Estr. da Barrocada 7200, Vila Galvão- Guarulhos \\
\hline$\overline{\mathrm{BT}-11}$ & Pedreira Itapeti & Estr. de Itapeti km 11- Mogi das Cruzes \\
\hline BT-12 & Pedreira Mariutti & Rodovia Régis Bittencourt km 294- Itapecerica da Serra \\
\hline BT-13 & Pedreira Alvenaria/Concremix & Sítio dos Dias s/n- Mairiporã \\
\hline BT-14 & Pedreira Cantareira & Rodovia Fernão Dias km 67- Mairiporã \\
\hline$\overline{B T-15}$ & Pedreira Itaquera & Estr. Itaquera 1.001, Cidade Líder- São Paulo \\
\hline BT-19 & Pedreira Panorama & Av. Raimundo Pereira de Magalhães, Perus- São Paulo. \\
\hline$\overline{\mathrm{BT}-21}$ & Pedreira Itacema & R. Cel Sezefredo Fagundes 19.500, Cachoeira- São Paulo. \\
\hline BT-22 & Pedreira Constran & Av. Constran s/n, Engenho Novo- Barueri. \\
\hline BT-23 & Pedreira São Matheus & R. Luiz Matheus s/n, Guaianazes- São Paulo. \\
\hline$\overline{B T-24}$ & Pedreira Itapiserra & Estr. Abias da Silva km 7,5- Itapecerica da Serra. \\
\hline$\overline{B T-25}$ & Pedreira Cachoeira & R. Cel. Sezefredo Fagundes 7.901, Cachoeira- São Paulo. \\
\hline$\overline{B T-26}$ & Pedreira Construcap & Av. Raimundo P.de Magalhães, Jd.Cidade Pirituba- São Paulo. \\
\hline$\overline{B T-27}$ & Pedreira Nassau & Estr. Arujá-Sta. Isabel, km 10- Santa Isabel. \\
\hline BT-28 & Empresa Britadora Santa Isabel & Morro Grande- Santa Isabel. \\
\hline$\overline{\mathrm{CA}-01}$ & Lolli Mineração & Estrada da Castelo s/n-Pirapora do Bom Jesus. \\
\hline $\mathrm{KI}-01$ & Empresa de Mineração Horii & Estr. das Varinhas km 52- Mogi das Cruzes. \\
\hline $\mathrm{KI}-02$ & ECC do Brasil Mineração & Estr. das Varinhas km 53- Mogi das Cruzes. \\
\hline $\mathrm{KI}-05$ & Sociedade Caolinita de Mineração & Estr. de Santa Rita 13.000- Embu-Guaçu \\
\hline $\mathrm{KI}-06$ & Mineração MM & Estr. de Santa Rita 12.001- Embu-Guaçu \\
\hline QZ-01 & Argamassas Quartzolit & Sítio Quartzolit- Pirapora do Bom Jesus. \\
\hline $\mathrm{RO}-01$ & Minergran & Estr. do Repiado, Sítio do Olímpio, Bairro Tietê- Salesópolis. \\
\hline
\end{tabular}

Obs.: AG-argila, AR-areia; BT-brita; CA-calcário; KI-caulim; QZ-quartizito; RO-rocha ornamental. 
FIGURA 5.1 - Localização das minas ativas estudadas na RMSP - Ver Pasta Desenhos 


\subsection{Aspectos gerenciais}

Os procedimentos gerenciais de recuperação de áreas degradadas em minas ativas na RMSP envolvem o acompanhamento de medidas executadas concomitantemente às atividades extrativas e destinadas principalmente àestabilização dos processos de degradação instalados. Entretanto, são poucos os casos de empreendimentos em que esses procedimentos tem sido praticados predominantemente em conformidade com o uso pós-mineração previsto na fase de planejamento e expresso em Prad ou outra documentação técnica correlata. O caráter de conformidade do empreendimento é dado pela constatação de que a maior parte das medidas praticadas corresponde æ̀ medidas previstas e vinculadas ao uso do solo planejado (TABELA $5.2)$.

TABELA 5.2- Minas ativas, segundo o caráter de conformidade do empreendimento em relação ao uso pós-mineração previsto em planejamento.

Minas ativas

em relação ao uso pós-mineração

\begin{tabular}{|c|c|c|}
\hline & \\
\hline & № & $\%$ \\
\hline Conforme & 6 & 14 \\
\hline Desconforme & 36 & 86 \\
\hline Total & 42 & 100 \\
\hline
\end{tabular}

A responsabilidade pelo gerenciamento dos trabalhos de recuperação na RMSP está, na maior parte das minas ativas, a cargo dos profissionais que desempenham a função de encarregado geral ou operacional nas instalações do empreendimento. Em alguns casos, como em pedreiras de produção de brita, a tarefa é acumulada pelo responsável técnico pelo empreendimento, geralmente engenheiro de minas. Não há casos em que o empreendimento dispõe, em regime de dedicação exclusiva e integral, de profissionais especializados em trabalhos de controle e recuperação ambiental, sendo raros os que os possuem em tempo parcial.

Nenhuma das minas conta com equipes especialmente dedicadas aos trabalhos de recuperação ou mesmo de controle ambiental. Os empreendimentos mobilizam funcionários de outras áreas (lavra, beneficiamento, manutenção de máquinas e equipamentos, entre outras) para a execução dessas tarefas. Em geral, os encarregados pelos empreendimentos 
reconhecem a necessidade e importância dos trabalhos de recuperação, porém costumam considerá-los extremamente onerosos e demorados.

As minas em que são notáveis o progresso e a eficiência na implementação de medidas de recuperação e, às vezes, na realização de experimentos que revelam um certo empenho em inovações técnicas, geralmente correspondem aos casos em que o responsável técnico pelo empreendimento acumula a coordenação dos trabalhos de recuperação, eventualmente assessorado por profissionais ou consultores com experiência prática em medidas de controle ambiental.

No entanto, a atitude gerencial demonstrada tanto pelos encarregados quanto pelos responsáveis técnicos é predominantemente reativa nas minas estudadas, particularmente em relação æ̀s solicitações ou exigências estabelecidas pelos órgãos ambientais de licenciamento ou fiscalização. Também são raros os procedimentos que visam a instituição, ampliação ou consolidação de diálogo com a comunidade e com os órgãos públicos, fundamentado na utilização dos recursos minerais de forma responsável e na perspectiva do desenvolvimento sustentável.

O caráter reativo é demonstrado pelo predomínio de medidas executadas única e exclusivamente em decorrência direta de vistorias realizadas por equipes de fiscalização. Poucas são as minerações em que predominam medidas implementadas como resultado de um caráter gerencial pró-ativo, ou seja, como conseqüência de atitudes tomadas de maneira antecipada pelas empresas, portanto independentemente de exigências dos órgãos ambientais e em conformidade com o plano de recuperação anteriormente estabelecido (TABELA 5.3).

TABELA 5.3- Minas ativas, segundo o caráter gerencial predominante no empreendimento.

\begin{tabular}{l|c|c}
\hline \multirow{2}{*}{ Caráter gerencial predominante } & \multicolumn{2}{c}{ Minas ativas } \\
\cline { 2 - 4 } & No & $\%$ \\
\hline Reativo & 31 & 74 \\
\hline Pró-ativo & 11 & 26 \\
\hline & 42 & 100 \\
\hline
\end{tabular}

Nas minas em que predomina uma atitude gerencial reativa, há casos em que visitas de caráter técnico-científico, como as realizadas nesta pesquisa, são abordadas com extrema desconfiança ou mesmo indisposição por parte dos encarregados, chegando-se a restringir o acesso a certas áreas do empreendimento e impedir os registros fotográficos. Por outro lado, nos empreendimentos com caráter gerencial pró-ativo, a conduta tende a favorecer o acesso 
aos diferentes setores da mina e propiciar a obtenção de informações, chegando-se a estabelecer, nas relações com visitantes, a abertura para recebimento de críticas e sugestões sobre as práticas adotadas.

Entre os empreendimentos em que prevalece o caráter gerencial pró-ativo, há alguns casos em que se implementa a organização e funcionamento de programas de comunicação com o meio externo, visando estabelecer canais de interação, tanto com a comunidade quanto com os órgãos públicos. Há, ainda, casos em que esses programas possuem derivações que envolvem também a comunidade interna, ou seja, os profissionais que trabalham na mineração.

Ainda no âmbito gerencial, verifica-se que os custos de recuperação não são contabilizados à parte pelas empresas de mineração, assim como os demais gastos com medidas de controle ambiental. Geralmente, esses custos são incluídos em meio æ̀ demais despesas operacionais realizadas rotineiramente nos empreendimentos. As poucas estimativas obtidas a partir de informações dos encarregados ou mesmo dos proprietários das empresas, dão conta de gastos ambientais da ordem de $10 \%$ do total das despesas operacionais. No entanto, esses dados possuem um grau de incerteza bastante elevado e não devem servir como referência.

Quanto à alocação das despesas, de acordo com o tipo de medida de recuperação aplicada, é generalizada a manifestação, por parte dos empreendedores, de que a adoção de certas medidas é inviável sob o ponto de vista econômico. Isto é especialmente mencionado em situações como as de emprego de medidas de revegetação com uso de espécies nativas, consideradas muito caras pelas empresas, sendo que as de exóticas também representam custos significativos. Abrem-se, assim, além da solução crescentemente adotada no sentido de instalar viveiros próprios para produção de mudas nativas e exóticas, as perspectivas para 0 desenvolvimento de medidas de revegetação baseadas na recuperação espontânea ou natural de espécies existentes na região do empreendimento.

Nenhuma das minerações apresenta um sistema de gerenciamento ambiental implementado, ou seja, uma estrutura organizacional e de funcionamento que articule todas as medidas ambientais realizadas no âmbito do empreendimento. Tampouco há uma aproximação com vistas àbusca de uma adequação à normalização técnica, seja nacional ou internacional, como, por exemplo, à série de normas de qualidade ambiental denominada ISO 14.000. Porém, algumas minas já apresentam programas ambientais que poderão evoluir rapidamente para a formulação e implementação de algum tipo de sistema de gerenciamento normalizado e reconhecido pelo meio externo.

\subsection{Medidas de recuperação praticadas}


As medidas de recuperação de áreas degradadas praticadas em minas ativas na RMSP, têm sido preparadas e executadas segundo as diferentes atividades ou setores da mineração em que a degradação ambiental ocorre.

A identificação das medidas está relacionada ao modo individualizado pelo qual são formuladas e implementadas por parte das empresas de mineração, envolvendo: áreas lavradas, que incluem principalmente cavas a céu aberto (secas ou inundadas) e frentes de lavra em bancadas ou cortes em taludes de encosta; áreas de depósitos de estéril e rejeitos, que incluem pilhas de bota-fora e bacias de decantação de rejeitos de beneficiamento; e áreas de infra-estrutura e de circunvizinhança, que incluem instalações de unidades de beneficiamento (britagem, moagem, lavagem, classificação), estocagem e expedição de minério, vias de acesso e circulação interna, oficinas de máquinas e equipamentos e, eventualmente, terrenos situados na circunvizinhança.

A aplicação das medidas geralmente se fundamenta em métodos e técnicas convencionais, raramente envolvendo inovações. O estágio de desenvolvimento e aplicação das medidas praticadas pode ser identificado de acordo com o grau de difusão nas minas ativas e a eficácia alcançada na correção ou estabilização dos processos de degradação ambiental.

Há algumas medidas que eventualmente poderiam ser classificadas como de recuperação, como a retenção e contenção de material particulado proveniente de unidades de britagem, por meio de umedecimento com uso de sistemas de aspersão d'água, ou o redimensionamento de planos de desmonte rochoso por explosivos. Porém, estes e outros tipos de medidas que, em princípio, estão relacionadas ao controle ambiental de um empreendimento mineiro, geralmente têm um caráter preventivo, enquanto que as medidas de recuperação têm uma associação intrínseca com processos de degradação, sendo formuladas com a finalidade de corrigí-los ou estabilizá-los.

Com base nesses aspectos e considerando, ainda, o grau de difusão no âmbito das minas ativas estudadas, as medidas de recuperação identificadas na RMSP são distingüidas segundo três categorias principais: disseminadas, emergentes e experimentais. Relacionam-se as medidas de acordo com o contexto em que são comumente encontradas, salientando as relações entre o tipo de bem mineral explotado e o relevo, visto que ambos permitem a associação com outras características importantes do meio físico (rochas e solos) e que condicionam a instalação dos processos de degradação ambiental sobre os quais as medidas tendem a atuar (TABELA 5.4). 
TABELA 5.4- Principais medidas de recuperação praticadas em minas ativas, segundo o grau de difusão e os respectivos contextos em que são comumente encontradas.

\begin{tabular}{|c|c|c|c|c|c|c|}
\hline & \multirow[b]{2}{*}{ Medidas de recuperação } & \multicolumn{5}{|c|}{ Contexto (bem mineral e relevo) } \\
\hline & & $\begin{array}{l}\text { Areia em } \\
\text { colinas ou } \\
\text { morros }\end{array}$ & $\begin{array}{l}\text { Areia em } \\
\text { planície } \\
\text { aluvionar }\end{array}$ & $\begin{array}{l}\text { Argila em } \\
\text { planície } \\
\text { aluvionar }\end{array}$ & $\begin{array}{l}\text { Brita em } \\
\text { morros }\end{array}$ & $\begin{array}{l}\text { Caulim } \\
\text { em } \\
\text { morros }\end{array}$ \\
\hline \multirow{5}{*}{$\begin{array}{l}\text { Medidas } \\
\text { disseminadas }\end{array}$} & Instalação de barreiras vegetais & $\mathrm{x}$ & $\mathrm{x}$ & $\mathrm{x}$ & $\mathrm{x}$ & $\mathrm{x}$ \\
\hline & Arborização dispersa na área da mineração & $\mathrm{x}$ & $\mathrm{x}$ & $\mathrm{x}$ & $\mathrm{x}$ & $\mathrm{x}$ \\
\hline & Remodelamento topográfico & $\mathrm{x}$ & $x$ & $x$ & $\mathrm{x}$ & $\mathrm{x}$ \\
\hline & Retaludamento e revegetação de áreas lavradas & $\mathrm{x}$ & $x$ & $\mathrm{x}$ & $x$ & $\mathrm{x}$ \\
\hline & Revegetação de taludes de barragens de rejeito & $\mathrm{x}$ & $\mathrm{x}$ & $\mathrm{x}$ & $x$ & $x$ \\
\hline \multirow{15}{*}{$\begin{array}{l}\text { Medidas } \\
\text { emergentes }\end{array}$} & $\begin{array}{l}\text { Remoção, estocagem e utilização da camada } \\
\text { orgânica do solo superficial }\end{array}$ & $\mathrm{x}$ & & & $x$ & \\
\hline & $\begin{array}{l}\text { Remoção, estocagem e utilização da camada } \\
\text { argilosa do solo superficial }\end{array}$ & $\mathrm{x}$ & & & $x$ & \\
\hline & $\begin{array}{l}\text { Remoção dirigida de estéreis e preenchimento de } \\
\text { cavas }\end{array}$ & & $\mathrm{x}$ & $\mathrm{x}$ & & $\mathrm{x}$ \\
\hline & $\begin{array}{l}\text { Instalação de sistemas de drenagem em barragens } \\
\text { de rejeito }\end{array}$ & $x$ & & & & \\
\hline & Reforço e revegetação em barragens de rejeito & $\mathrm{x}$ & & & & \\
\hline & Instalação de extravasores em barragens de rejeito & $x$ & & & & \\
\hline & $\begin{array}{l}\text { Transposição de rejeitos de bacias de decantação } \\
\text { para áreas lavradas }\end{array}$ & $\mathrm{X}$ & & & & $\mathrm{x}$ \\
\hline & $\begin{array}{l}\text { Instalação de sistemas de drenagem e retenção de } \\
\text { sedimentos }\end{array}$ & $\mathrm{x}$ & & & $\mathrm{x}$ & \\
\hline & Construção e estabilização de bota-foras & & & & $\mathrm{x}$ & \\
\hline & Retenção e coleta de óleos e graxas & $\mathrm{x}$ & $\mathrm{x}$ & & $\mathrm{x}$ & $\mathrm{x}$ \\
\hline & $\begin{array}{l}\text { Revegetação de taludes em acessos e vias } \\
\text { internas }\end{array}$ & $x$ & & & $x$ & $\mathrm{x}$ \\
\hline & $\begin{array}{l}\text { Remoção de blocos rochosos instáveis em áreas } \\
\text { lavradas }\end{array}$ & $\mathrm{x}$ & & & $\mathrm{x}$ & \\
\hline & $\begin{array}{l}\text { Abatimento e revegetação de taludes marginais } \\
\text { em lagos remanescentes }\end{array}$ & & $x$ & & & \\
\hline & Proteção e manejo da vegetação remanescente & $\mathrm{x}$ & $\mathrm{x}$ & & $\mathrm{x}$ & \\
\hline & Indução e manejo da revegetação espontânea & $x$ & $x$ & & $x$ & \\
\hline Medidas & Revegetação em bermas e taludes rochosos & & & & $x$ & \\
\hline experimentais & Revegetação de solos de alteração de rochas & $\mathrm{x}$ & & & & \\
\hline
\end{tabular}

A seguir, discutem-se as principais medidas de recuperação identificadas em minas ativas na RMSP, segundo as categorias adotadas (disseminadas, emergentes ou experimentais), avaliando-as quanto às finalidades, procedimentos técnicos usuais e 
desempenho em relação aos resultados esperados. No caso do desempenho, consideram-se alguns indicadores que permitem estimar a eficácia das práticas atuais na correção dos processos de degradação, sendo classificado em satisfatório, regular ou insatisfatório. A avaliação das medidas contempla também a verificação de eventuais mudanças qualitativas em relação a práticas anteriores, melhoria significativa da qualidade ambiental do empreendimento e a possibilidade de transferência das técnicas desenvolvidas para outras minas.

\subsubsection{Medidas disseminadas}

As medidas disseminadas compreendem os trabalhos de recuperação que podem ser identificados e avaliados na área do empreendimento mineiro, sendo praticadas na maior parte das minas ativas.

\subsubsection{Instalação de barreiras vegetais}

Este tipo de medida consiste no plantio alinhado e equidistante de mudas de espécies vegetais árboreas ou arbustivas. Tem sido praticada com a finalidade principal de evitar a percepção humana, eliminando ou atenuando o impacto visual causado pelo contraste entre extensas áreas denudadas e a circunvizinhança, especialmente sob o ponto de vista de um observador distante e situado em local externo à mineração. Secundariamente, visa também reduzir os incômodos gerados pelo ruído e material particulado em suspensão no ar (poeira) provenientes da mineração, particularmente de unidades de britagem, transporte interno e carregamento do produto em pedreiras, bem como diminuir as possibilidades de arraste eólico na área do empreendimento.

As barreiras são comumente dispostas em linha única de mudas ou em faixa ao longo da divisa entre a área ocupada pelo empreendimento e as propriedades circunvizinhas. As barreiras em linha única são predominantes, sendo que as de faixa são compostas geralmente por duas a quatro linhas paralelas intercaladas ou com disposição aleatória das mudas, com largura não superior a $7 \mathrm{~m}$. Menos freqüentes e extensas são as barreiras instaladas no interior da área da mineração, em que costumam estar ao longo da margem de vias de circulação interna, æ̀ vezes alternando os tipos de espécies vegetais plantadas ou dividindo setores do processo produtivo. Há, ainda, barreiras instaladas fora da área da mineração, em locais de circulação viária, geralmente executadas por iniciativa da comunidade vizinha com o objetivo de eliminar ou atenuar o impacto visual causado pelo empreendimento. Nestas últimas, as barreiras geralmente compõem faixas com adensamento relativamente maior (FOTOS 1 a 6 ). 
A medida tem sido executada por meio de plantio manual de mudas de espécies arbóreas exóticas, geralmente pinheiro (Pinus $s p$ ) e eucalipto (Eucalyptus sp). Há casos de barreiras com uso de espécies nativas, porém menos freqüentes e ainda com mudas de pequeno porte (FOTO 7). Barreiras com espécies arbustivas ou mesmo mistas (arbóreas e arbustivas) são incomuns. As mudas de espécies arbóreas têm, no momento do plantio, altura variando entre 1 e $2 \mathrm{~m}$, sendo plantadas com auxílio de ferramentas manuais em covas com cerca de $40 \mathrm{~cm}$ de profundidade e com espaçamento variando em torno de $5 \mathrm{~m}$. A opção pelas espécies de pinheiro e eucalipto tem sido condicionada não apenas pelo fato de que apresentam características desejáveis ao bom desenvolvimento das barreiras (crescimento muito rápido e pouca exigência às condições de solo e clima), mas também pela facilidade de aquisição no mercado, tanto em termos de disponibilidade como de preço. No caso de opção por espécies nativas, a alternativa tem sido a construção de pequenos viveiros na área da mineração para a própria produção de mudas (FOTO 8).

O desempenho desta medida em relação ao impacto visual pode ser considerado regular a insatisfatório em boa parte dos casos, sendo eficaz apenas nos casos em que as mudas atingem porte superior a $6 \mathrm{~m}$ e o adensamento da vegetação propicia sombreamento total da área em que a barreira se encontra instalada. A eficácia da medida tende a ser maior nos casos de plantios em faixas, contendo duas ou mais linhas de barreiras. No que se refere à redução de ruído e à retenção de material particulado, o desempenho é geralmente incerto, principalmente em razão do freqüente plantio em linha única e da generalizada ausência de vegetação arbustiva que, associada à arbórea, permitiria a atenuação do arraste eólico produzido pelos ventos baixos.

\subsubsection{Arborização dispersa na área da mineração}

Esta medida compreende o plantio de mudas de espécies vegetais arbóreas, distribuídas de maneira aleatória na área do empreendimento. Geralmente é praticada com a finalidade de atenuar o impacto visual causado pelos contrastes existentes na mineração e proporcionar um ambiente de trabalho mais agradável. Inclui-se, ainda, particularmente ao longo e proximidades dos limites do empreendimento, o objetivo de evitar invasões e ocupações de terra e, com isso, proteger a propriedade em que a mina está instalada (FOTO 9). 


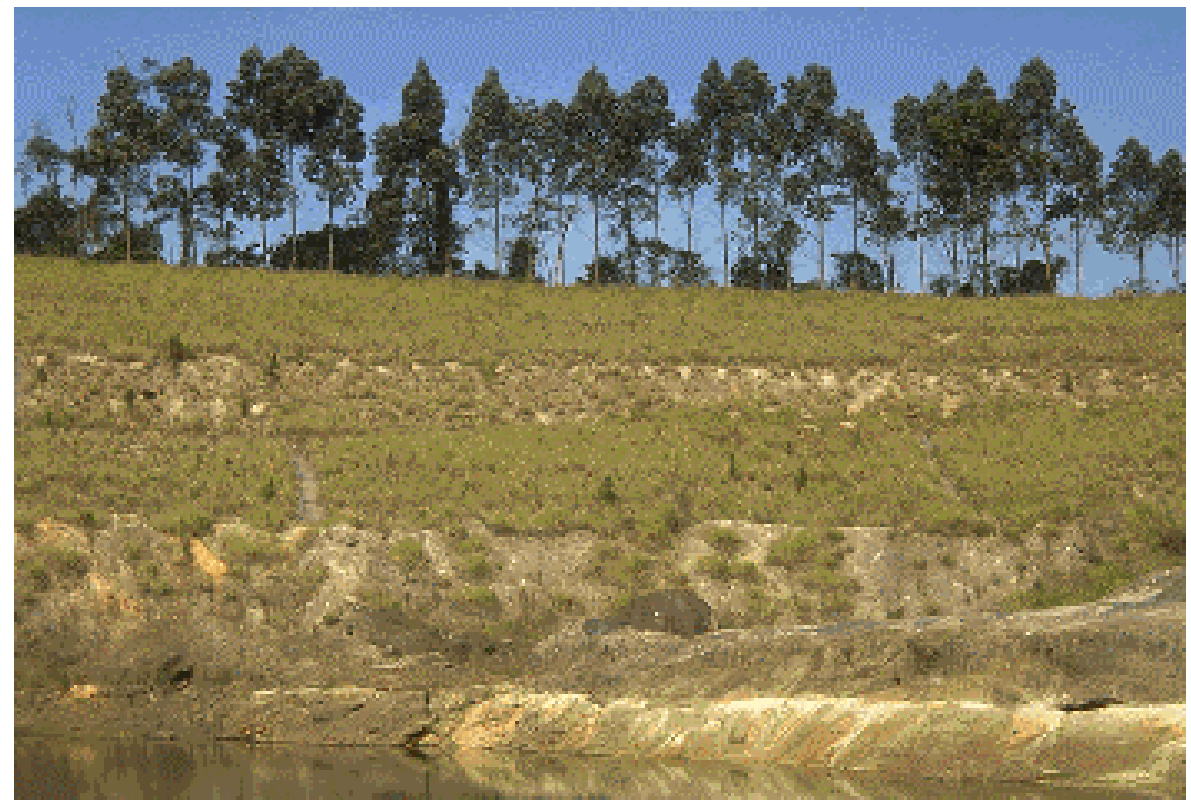

FOTO 1 - Barreira vegetal em linha única composta de eucaliptos, instalada na divisa entre a área da mineração e a propriedade circunvizinha. Mineração de areia Viterbo Machado Luz, São Paulo ( AR-07 ).

FOTO 2 -Barreiras vegetais em faixas compostas de eucaliptos (à direita) e de pinheiros (à esquerda), instaladas ao longo da via de circulação interna. Mineração de areia Viterbo Machado Luz,

São Paulo ( AR-07).
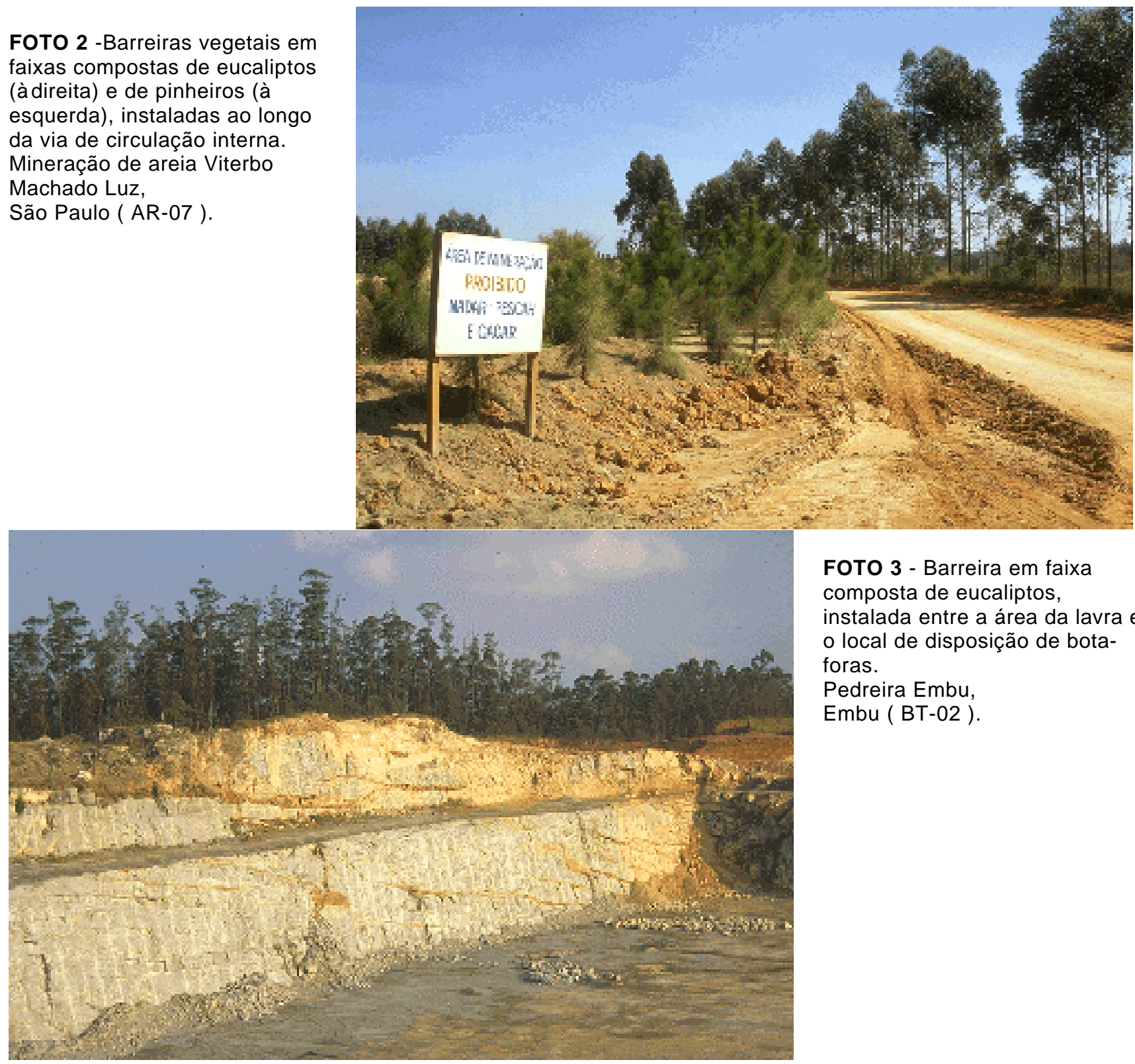

FOTO 3 - Barreira em faixa composta de eucaliptos, instalada entre a área da lavra e o local de disposição de botaforas.

Pedreira Embu, Embu ( BT-02 ). 


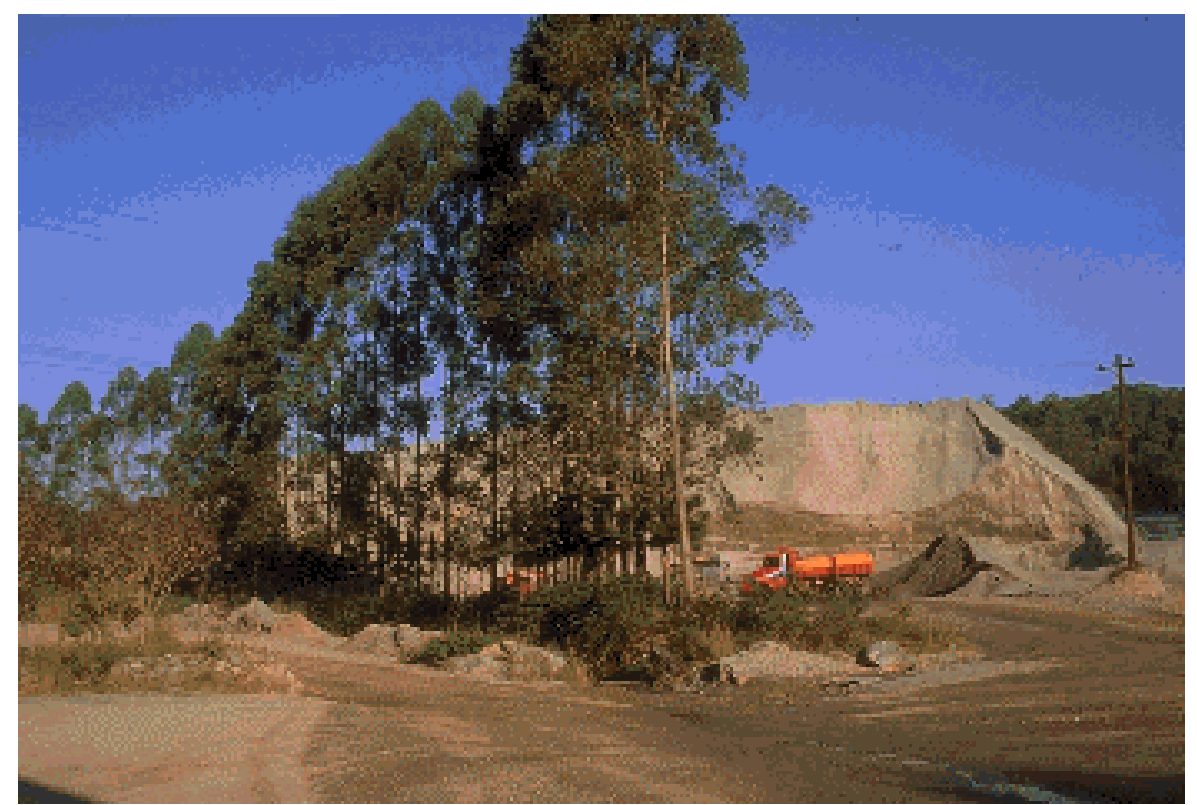

FOTO 4 - Barreira vegetal em linha única composta de eucaliptos, instalada entre a via de circulação interna e a pilha de estocagem do produto.

Pedreira Mariutti,

Itapecerica da Serra ( BT-12).

FOTO 5 - Barreira vegetal em linha única composta de pinheiros instalada entre a via de circulação interna e a área de estocagem do produto.

Mineração de areia Ponte Alta, São Paulo ( AR-26).
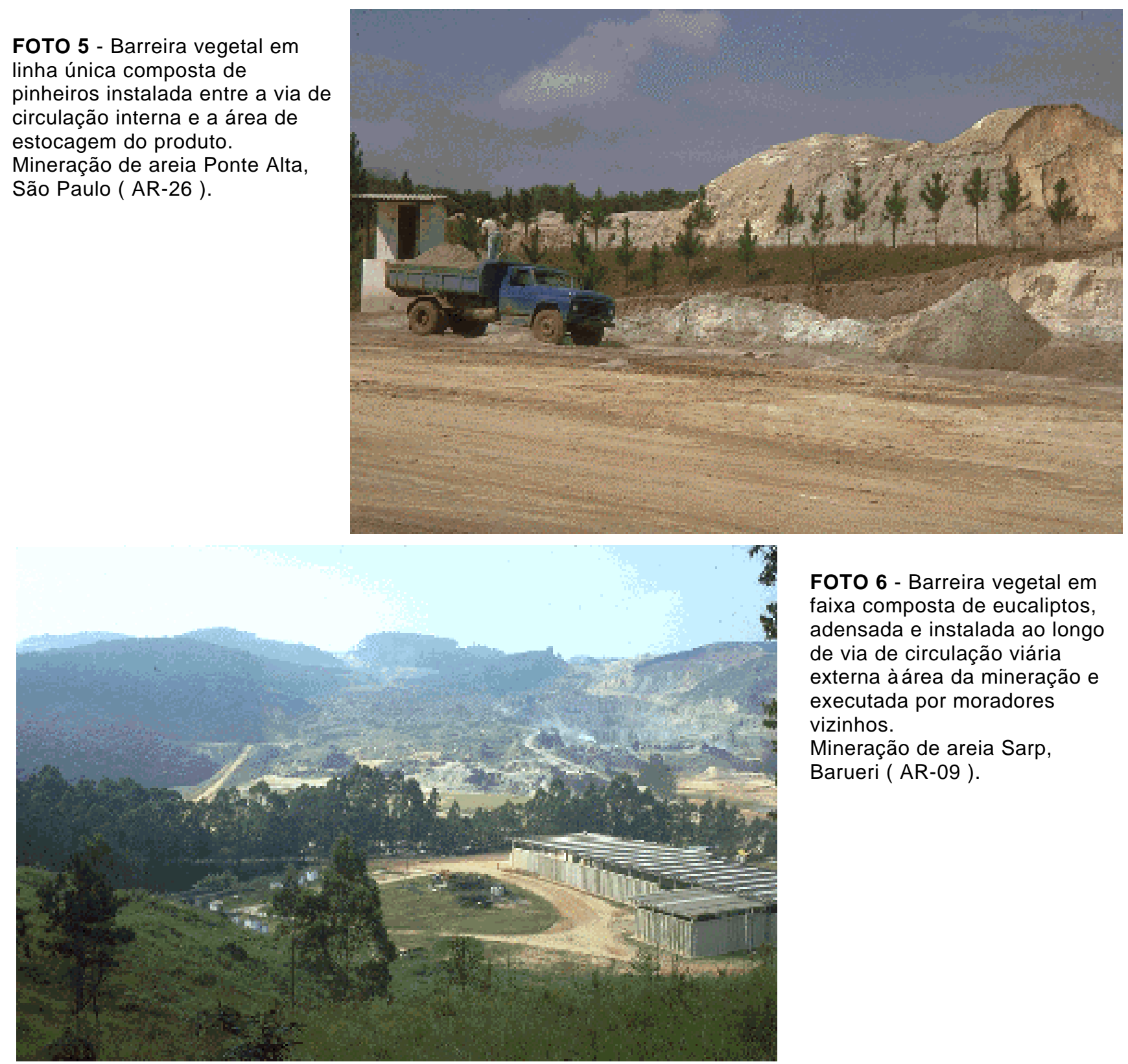

FOTO 6 - Barreira vegetal em faixa composta de eucaliptos, adensada e instalada ao longo de via de circulação viária externa àárea da mineração e executada por moradores vizinhos.

Mineração de areia Sarp, Barueri ( AR-09). 


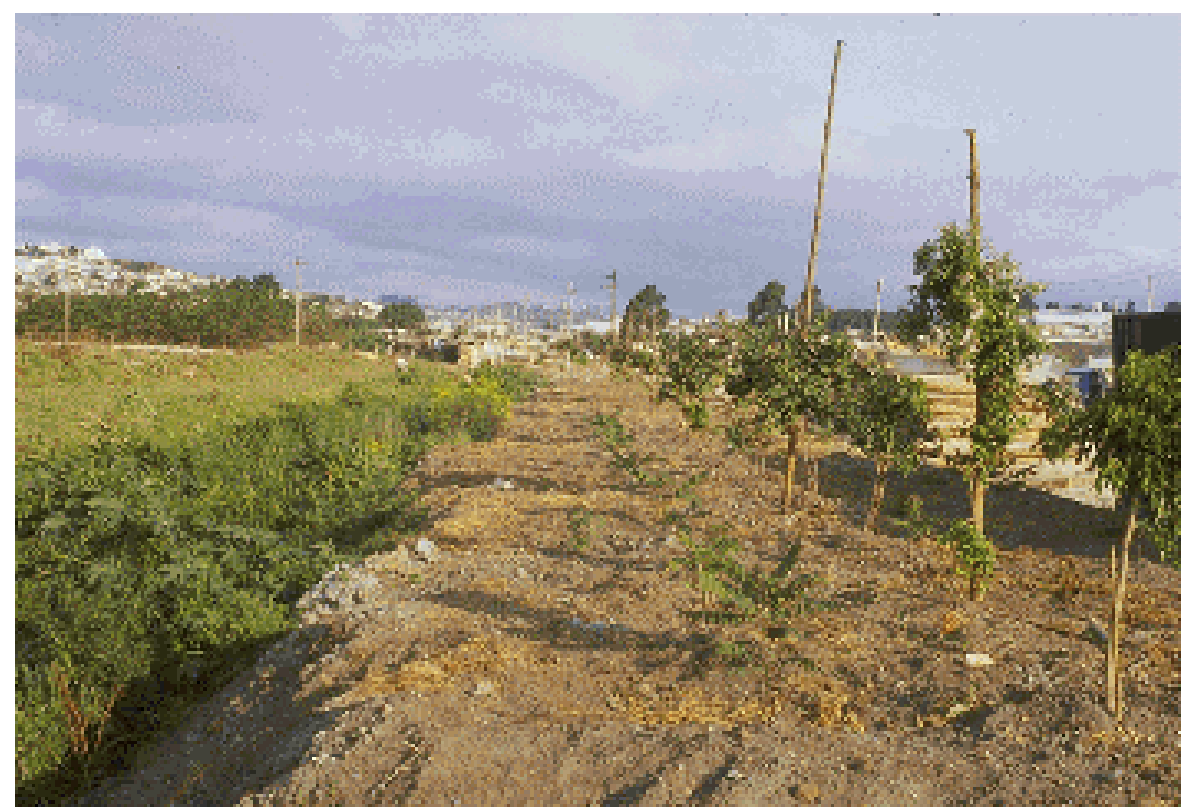

FOTO 7 -Barreira vegetal composta de mudas de espécies arbóreas nativas, plantada sob aterro de $1,5 \mathrm{~m}$ de solo do decapeamento, instalada no limite entre a área da mineração e a propriedade vizinha.

Mineração de areia Caravelas, Mogi das Cruzes ( AR-01).

FOTO 8 - Viveiro de mudas de espécies abóreas nativas.

Mineração de areia Ponte Alta, São Paulo ( AR-26).
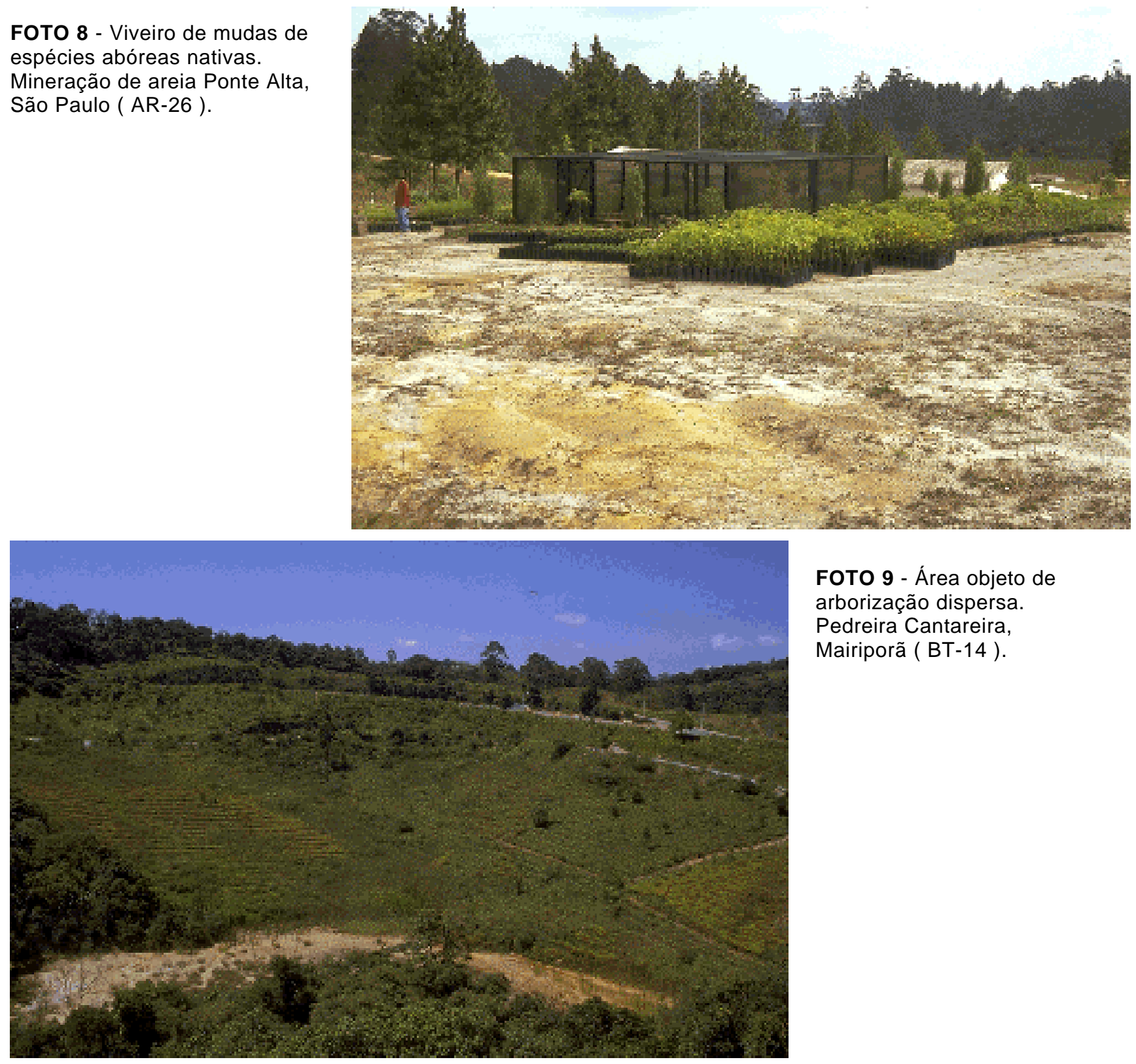

FOTO 9 - Área objeto de arborização dispersa. Pedreira Cantareira, Mairiporã ( BT-14 ). 
A medida é executada geralmente por meio de plantio manual e esparsado de mudas de espécies arbóreas exóticas, similares às utilizadas na instalação de barreiras vegetais (pinheiro e eucalipto). A idade das mudas exóticas utilizadas no plantio varia em torno de 1 a 2 anos, com altura média de cerca de $2 \mathrm{~m}$. As árvores plantadas têm cerca de 6 a 8 anos e atingem alturas de até $8 \mathrm{~m}$. Às vezes, utilizam-se espécies nativas.

O desempenho em relação à totalidade da área de mineração pode ser considerado, ainda, insatisfatório, embora, localmente, ocorram situações em que esteja contribuindo para a atenuação dos impactos. Há notáveis dificuldades de desenvolvimento de mudas em face dos solos compactados, sobretudo de mudas de espécies nativas, visto que o plantio precedido de revolvimento profundo ou mesmo de alguma escarificação não tem sido utilizado. Tampouco é comum a prática de proteger o solo da erosão laminar, por meio de cobertura com espécies herbáceas forrageiras, cuja implantação tende a ser muito rápida e eficiente. Outra dificuldade, no caso do plantio em áreas próximas ao limite dos terrenos ocupados pelos empreendimentos, está na ocorrência de incêndios, exigindo o treinamento especial de equipes de prevenção e combate ao fogo.

\subsubsection{Remodelamento topográfico}

Esta medida compreende basicamente a realização de terraplenagem simples, redesenhando superfícies topográficas irregulares existentes na área da mineração. Comumente, esta medida envolve a confecção de superfícies muito diferentes daquela existente no período pré-mineração. Configura o remodelamento da paisagem de forma a obter uma superfície esteticamente harmoniosa em relação ao meio circundante. Tem sido praticada com a finalidade de atenuar o impacto visual e reduzir a possibilidade de deflagração de processos erosivos (laminar ou linear), estabilizando os terrenos e tornando aptas a um novo uso as áreas que apresentam topografia irregular. Às vezes, visa também fornecer material de empréstimo, especialmente solos, para a execução de obras auxiliares no âmbito do empreendimento.

O remodelamento topográfico é geralmente executado com o auxílio de máquinas e equipamentos disponíveis no âmbito da mineração, como retroescavadeiras, tratores de esteira e caminhões. Às vezes é acompanhada de escarificação e revolvimento do solo, sobretudo na fase final, objetivando reduzir o grau de compactação e facilitar a revegetação que freqüentemente a sucede. O manejo das máquinas requer a compatibilização com o sistema de captação e disciplinamento das águas pluviais, de modo a evitar a erosão. Para 
tal, tem sido realizada com o concurso de condutores treinados e experientes, de maneira a obter a conformação topográfica desejada.

Os resultados dos trabalhos de remodelamento permitem caracterizar o desempenho desta medida como regular, visto que geralmente atendem de modo parcial as finalidades. É comum a existência, em um mesmo empreendimento, de terrenos estáveis e esteticamente harmoniosos com outros em degradação acelerada por processos erosivos, sendo que ambos foram objeto de remodelamento topográfico. As situações melhor sucedidas estão nos casos de empreendimentos em que se favorece a instalação subseqüente de espécies herbáceas forrageiras, cuja fixação, natural ou plantada, auxiliam na rápida cobertura do solo denudado contra a ação erosiva das águas pluviais.

\subsubsection{Retaludamento e revegetação de áreas lavradas}

Esta medida compreende, inicialmente, o retaludamento de superfícies finais de extração mineral que apresentam declividades altas (geralmente superiores a 20\%) e cujo eventual preenchimento com material de empréstimo exigiria volumes bastante significativos. Caracteriza-se pela execução exclusiva de cortes ou pela combinação de cortes e aterros, em frentes de lavra abandonadas situadas em relevos pouco suaves (morros, morrotes ou colinas) e com presença de solos de alteração ou de sedimentos terciários. O material de aterro é obtido na própria frente de lavra abandonada. O objetivo é gerar uma sucessão de bermas e taludes, seguidos de revegetação. Visa especialmente a estabilização geotécnica dos terrenos lavrados e a atenuação do impacto visual.

Os cortes são predominantes na execução desta medida, havendo poucos casos em que aterros também são confeccionados. As dimensões geométricas obtidas apresentam muitas variações, sobretudo na relação entre a largura da berma e a altura do talude. Comumente oscilam em torno de 1:2, com bermas de cerca de 2 a $3 \mathrm{~m}$ e os taludes entre 4 e 6 m. As bermas raramente apresentam a necessária inclinação suave e negativa, tanto transversal como longitudinal. A inclinação transversal negativa, ou seja, o caimento no sentido do interior do maciço rochoso ou terroso, com valores pouco superiores a $2^{\circ}$, tende a propiciar uma condução mais eficaz das águas pluviais. Após a conformação de bermas e taludes, executa-se a revegetação, por meio de plantio manual de mudas ou de hidrossemeadura. Geralmente, adotam-se espécies arbóreas nas bermas e herbáceas nos taludes, havendo casos em que se verifica o inverso. Há diversas situações em que se verifica o resultado da propagação e fixação natural de mudas, correspondentes a espécies vegetais arbóreas plantadas manualmente nas bermas (como pinheiro), provavelmente a partir de sementes trazidas por pássaros e pela ação das águas pluviais e do vento 
Os principais problemas de desempenho desta medida residem na ausência ou deficiência de sistemas de drenagem, variando, de acordo com o caso, entre regular e insatisfatório. Os indicadores são dados pela presença e dimensão de sulcos erosivos e de massas movimentadas, o que têm conferido um desempenho regular desta medida. Raros são os casos em que se encontram canaletas longitudinais na interface entre os taludes e as bermas, bem como escadas d'água de concreto ou canaletas transversais ao longo dos taludes (FOTO 10). Murundus ou leiras de isolamento nas bermas, próximos à crista dos taludes, também são pouco utilizados.

A revegetação instalada tenderia a auxiliar na estabilidade física dos terrenos, desde que precedida de uma correta análise das condições do meio físico em que se procede o plantio. Isto, particularmente quanto às suscetibilidades determinadas pela natureza dos terrenos expostos e pela ausência ou presença de solos superficiais (solo laterítico ou horizontes pedológicos $\mathrm{O}, \mathrm{A}$ e B) e solos de alteração (solo saprolítico ou horizonte pedológico C). Comparativamente, os efeitos erosivos em solos de alteração de rochas cristalinas são relativamente mais acentuados do que nos de sedimentos terciários, diferenciação freqüentemente não considerada. A falta de análise deste aspecto, bem como as deficiências de drenagem, tem tornado comum os casos em que são flagrantes as dificuldades e insucessos da revegetação, principalmente nos empreendimentos instalados em solos derivados de rochas cristalinas de idade pré-cambriana (FOTOS 11 a 13).

\subsubsection{Revegetação de taludes de barragens de rejeito}

Compreende o plantio de espécies vegetais arbóreas, arbustivas e herbáceas nos taludes internos e externos de barragens e diques de bacias de decantação de rejeitos finos. É especialmente aplicada em barragens que se encontram em sua fase final de funcionamento, sendo comum em minerações de areia situadas no contexto de solos de alteração de rochas cristalinas e de sedimentos terciário-quaternários. Visa atenuar o impacto visual, preservar a integridade da barragem, evitar a instalação de processos erosivos nos taludes externos e, em decorrência, impedir a produção e o fornecimento de sedimentos aos cursos d'água situados a jusante (FOTOS 14 e 15).

Nos taludes internos das barragens, a execução do plantio ocorre exclusivamente por meio da colacação de gramíneas forrageiras, tanto pelo lançamento manual de sementes quanto pela colocação de placas ou plantio de mudas em touceiras. Nos taludes externos e permanentemente emersos, também ocorre o plantio de gramíneas, porém às vezes acompanhado da implantação de mudas de espécies arbóreas exóticas, principalmente de eucalipto e pinheiro. 


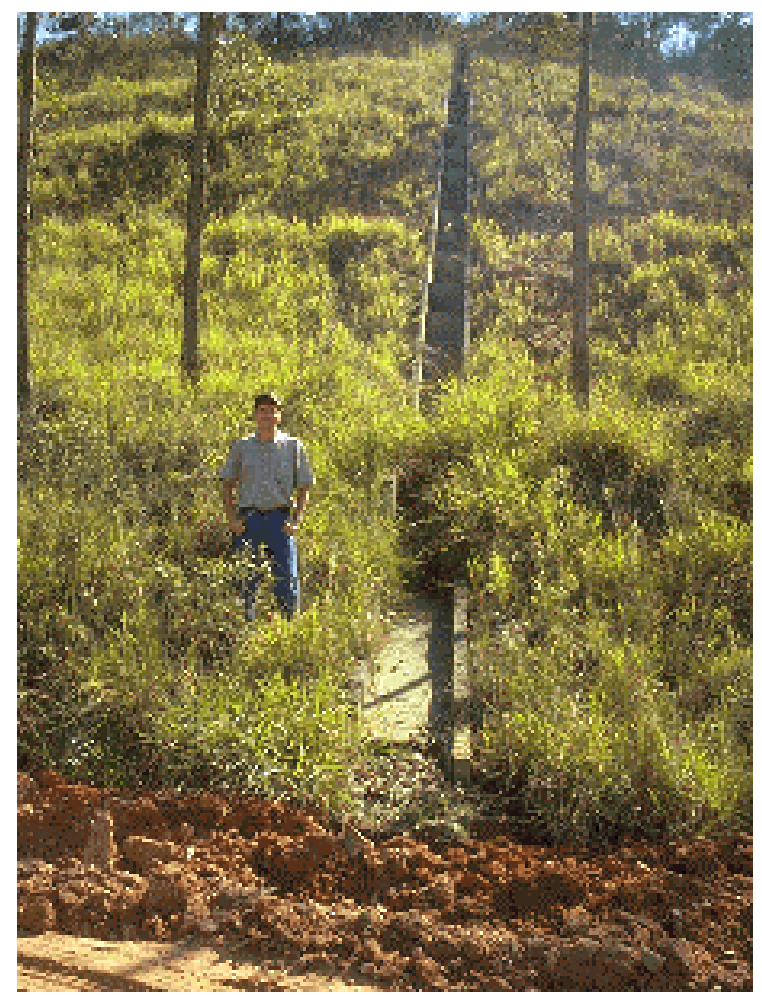

FOTO 10 - Escadas d'água em canaletas de concreto transversais, ao longo de taludes revegetados em antigas frentes de lavra.

Mineração de areia Viterbo Machado Luz,

São Paulo ( AR-07 ).

FOTO 11 - Plantio de pinheiros em área retaludada e com solo de alteração de sedimentos terciários (solo saprolítico ou horizonte pedológico $\mathrm{C}$ ), resultando em sulcos erosivos entre as mudas, decorrentes da ação das águas pluviais. Mineração de areia Floresta Negra,

Guarulhos ( AR-15 ).
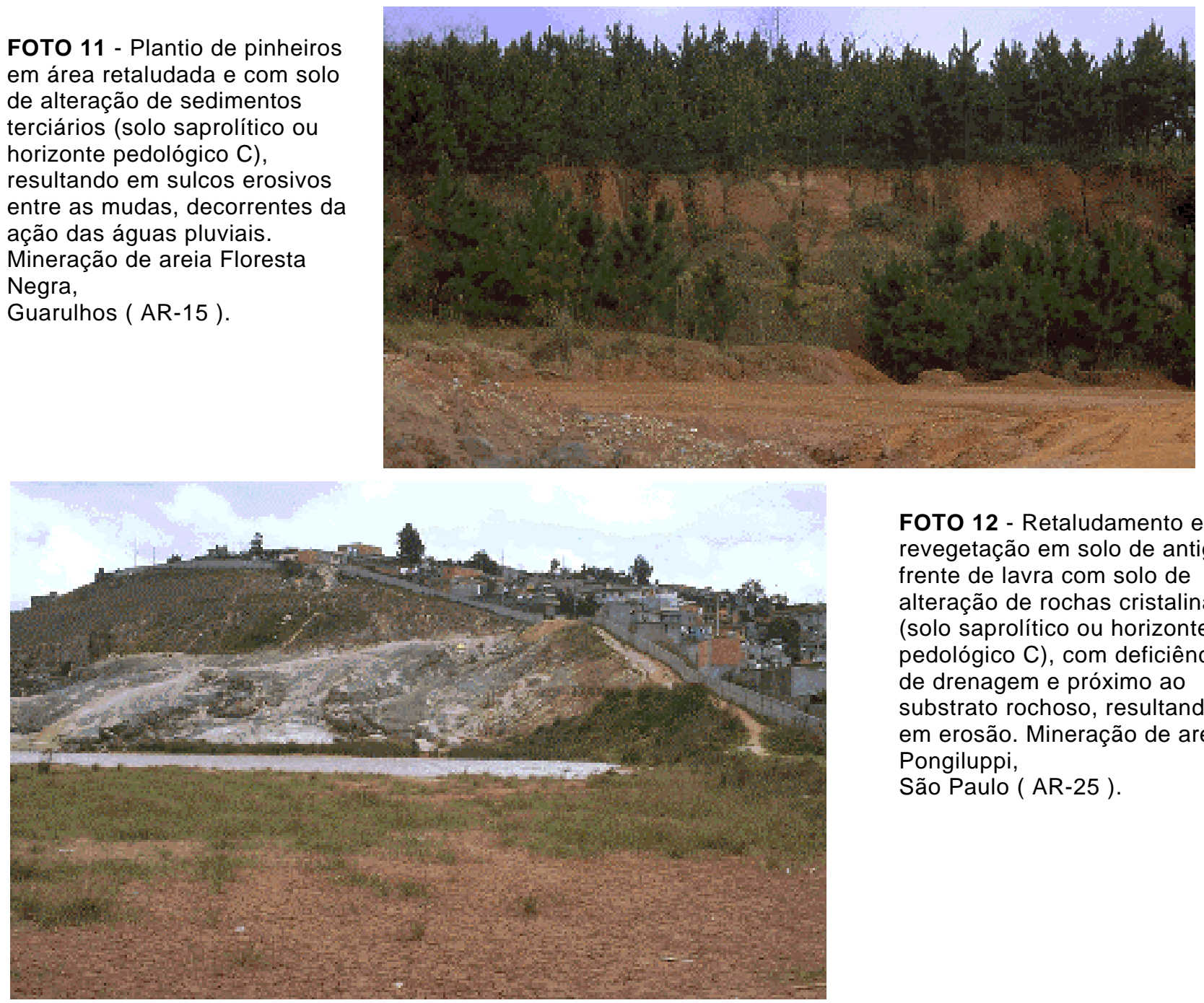

FOTO 12 - Retaludamento e revegetação em solo de antiga frente de lavra com solo de alteração de rochas cristalinas (solo saprolítico ou horizonte pedológico $\mathrm{C}$ ), com deficiências de drenagem e próximo ao substrato rochoso, resultando em erosão. Mineração de areia Pongiluppi, São Paulo ( AR-25 ). 


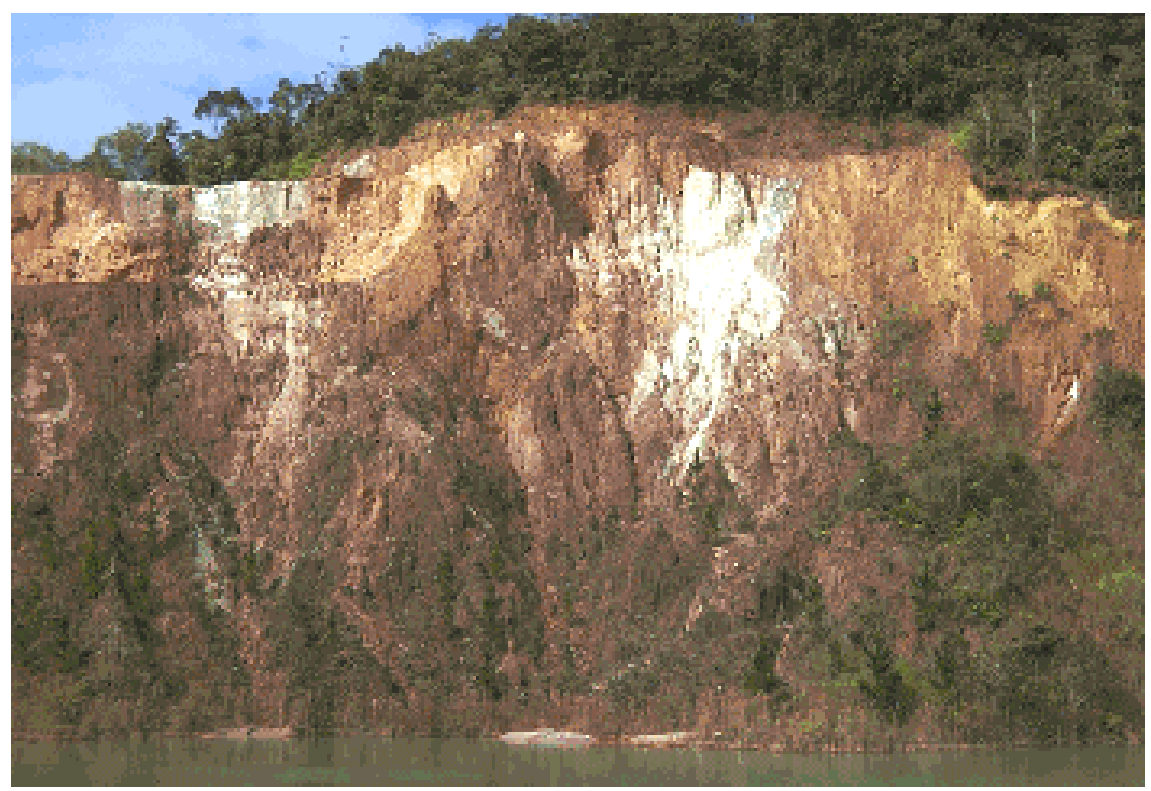

FOTO 13 - Retaludamento parcial e plantio de espécies arbóreas em solo de alteração de rochas cristalinas (solo saprolítico ou horizonte pedológico $\mathrm{C}$ ), sem sistema de drenagem, resultando em erosão e escorregamentos.

Mineração de caulim MM

Embu-Guaçu ( KI-06 ).

FOTO 14 - Plantio de gramíneas em talude interno da barragem de bacia de rejeitos.

Mineração de areia Floresta Negra,

Guarulhos ( AR-15).
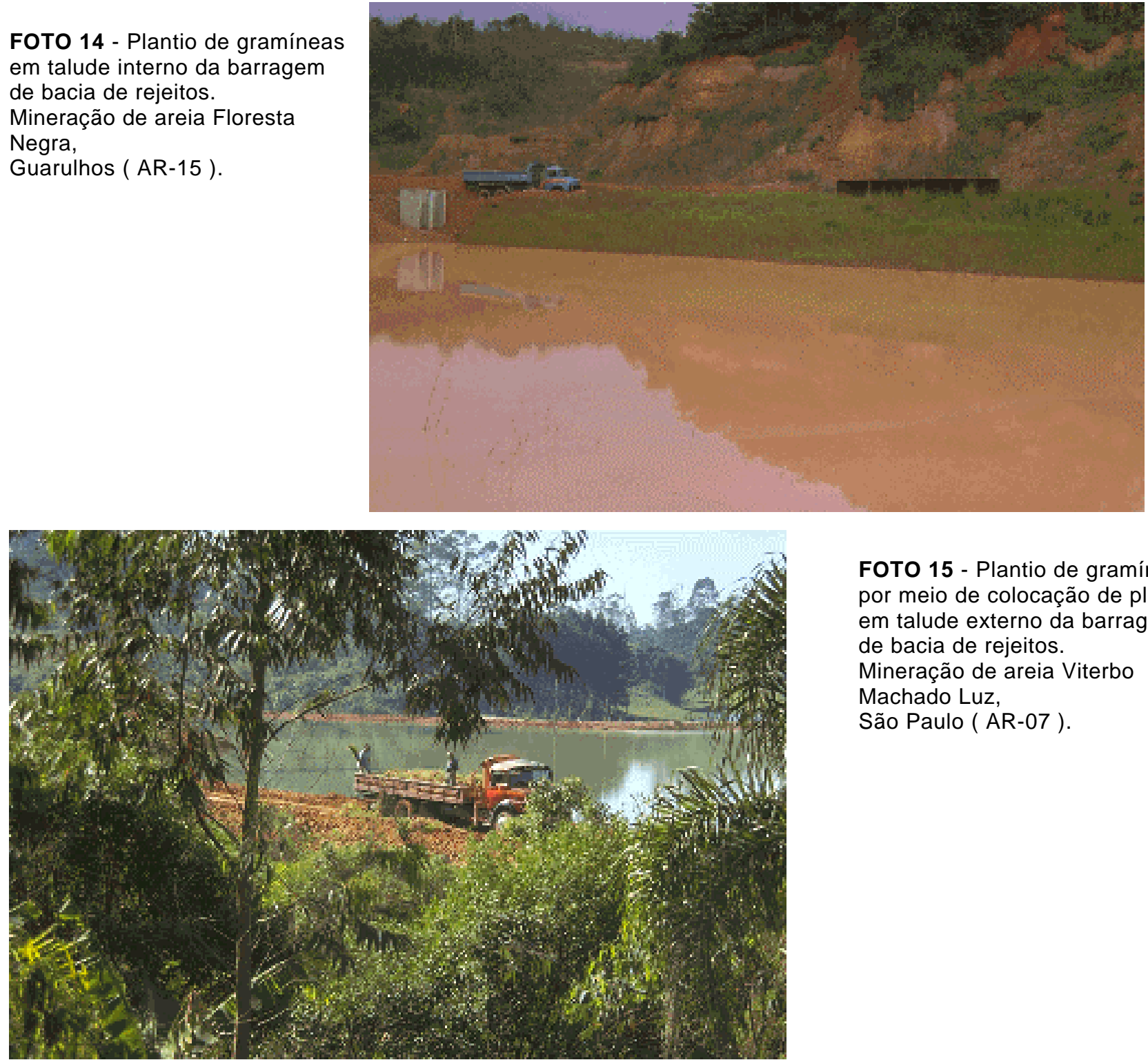

FOTO 15 - Plantio de gramíneas, por meio de colocação de placas em talude externo da barragem de bacia de rejeitos.

Mineração de areia Viterbo Machado Luz,

São Paulo ( AR-07). 
O desempenho desta medida tem se mostrado satisfatório apenas nos taludes internos das barragens de rejeitos. Nos externos ocorrem evidentes problemas devidos ao plantio direto de espécies arbóreas na superfície dos taludes. Isto não só tem se mostrado ineficaz no controle da erosão (ocorrem frequentemente sulcos acentuados, com até cerca de $50 \mathrm{~cm}$ de profundidade), como também, em razão do desenvolvimento de raízes, tende a favorecer a infiltração de água através do corpo da barragem e, assim, instabilizá-la (FOTO 16). Mesmo nos casos de plantio exclusivo de espécies herbáceas, há situações em que, por deficiências no sistema de drenagem, os resultados não atendem as finalidades desejadas (FOTO 17).

\subsubsection{Medidas emergentes}

As medidas emergentes compreendem os trabalhos de recuperação que podem ser identificados e avaliados na área da mineração, porém em condições ainda pouco difundidas entre as empresas da região e praticadas em um número relativamente reduzido de minas ativas.

\subsubsection{Remoção, estocagem e utilização da camada orgânica do solo superficial}

Esta medida envolve a remoção, estocagem e utilização da camada orgânica do solo superficial ou laterítico, que compreende os horizontes pedológicos $\mathrm{O}$ (composto de restos vegetais; também denominada de serapilheira) e A (composto por mistura de matéria orgânica e mineral), com um total de cerca de 20 a $40 \mathrm{~cm}$ de espessura. Visa utilizar o solo nos trabalhos de revegetação, como na cobertura de áreas lavradas e pilhas de estéreis ou rejeitos, formando a base para a instalação subseqüente de cobertura vegetal.

Em frentes de lavra que ainda apresentam cobertura vegetal original e significativa, a remoção do solo é precedida de desmatamento e destocamento. A medida é geralmente realizada concomitantemente às atividades produtivas, iniciando-se durante as operações de decapeamento e lavra, por meio de tratores de esteira e caminhões (FOTO 18). Não tem sido feita a separação entre os horizontes O e A. Há casos em que a separação das camadas de solo orgânico ( $\mathrm{O}$ e $\mathrm{A}$ ) deixa de ser realizada em virtude de sua pequena espessura ocorrente, como se verifica em algumas situações de pedreiras instaladas no topo de elevações topográficas.

Nas minas em que esta medida é aplicada plenamente, ou seja, estocando e utilizando a camada de solo retirada, os resultados são bastante satisfatórios em relação à instalação e desenvolvimento de vegetação. 


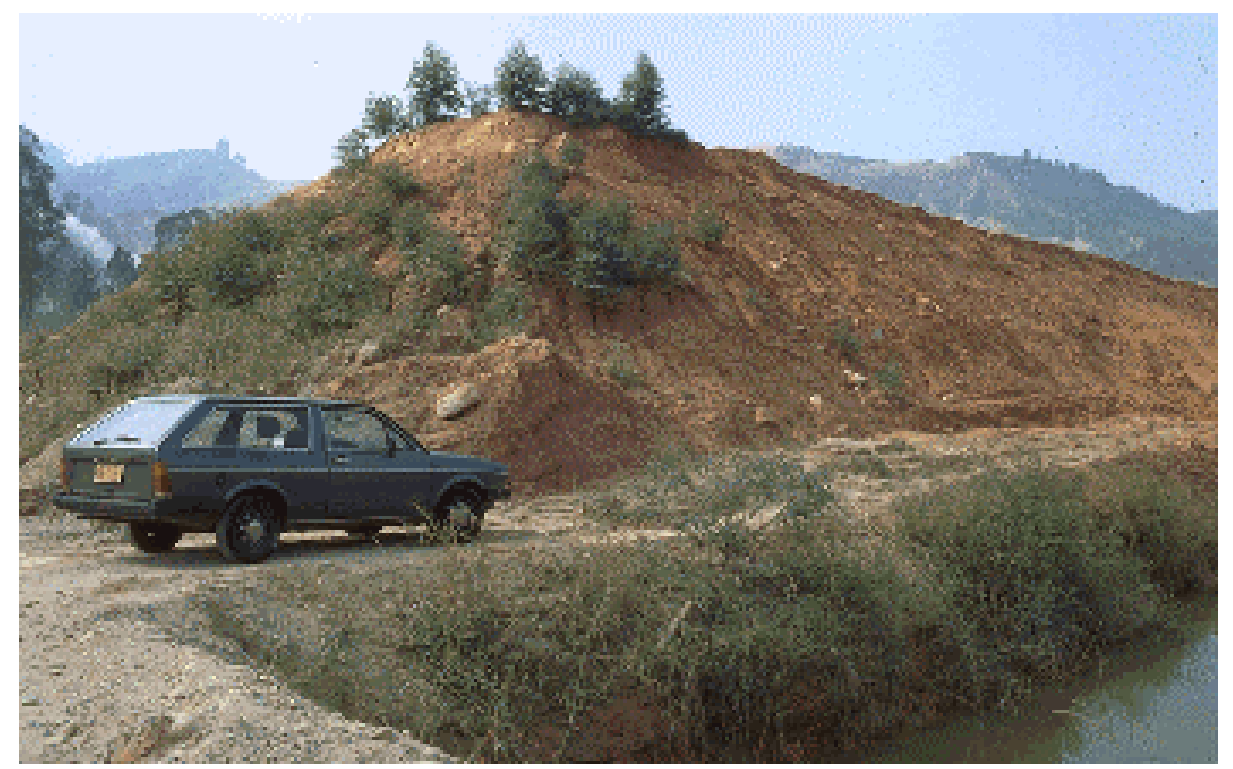

FOTO 16 - Eucaliptos plantados em talude externo de barragem de rejeito de mina de areia, resultando em sulcos erosivos. Mineração de areia Sarp, Barueri ( AR-09).

FOTO 17 - Espécies herbáceas plantadas nos taludes externos de barragem de rejeitos. $A$ ausência de drenagem no topo da barragem resulta em sulcos erosivos no talude.

Mineração de areia Sarp, Barueri ( AR-09).
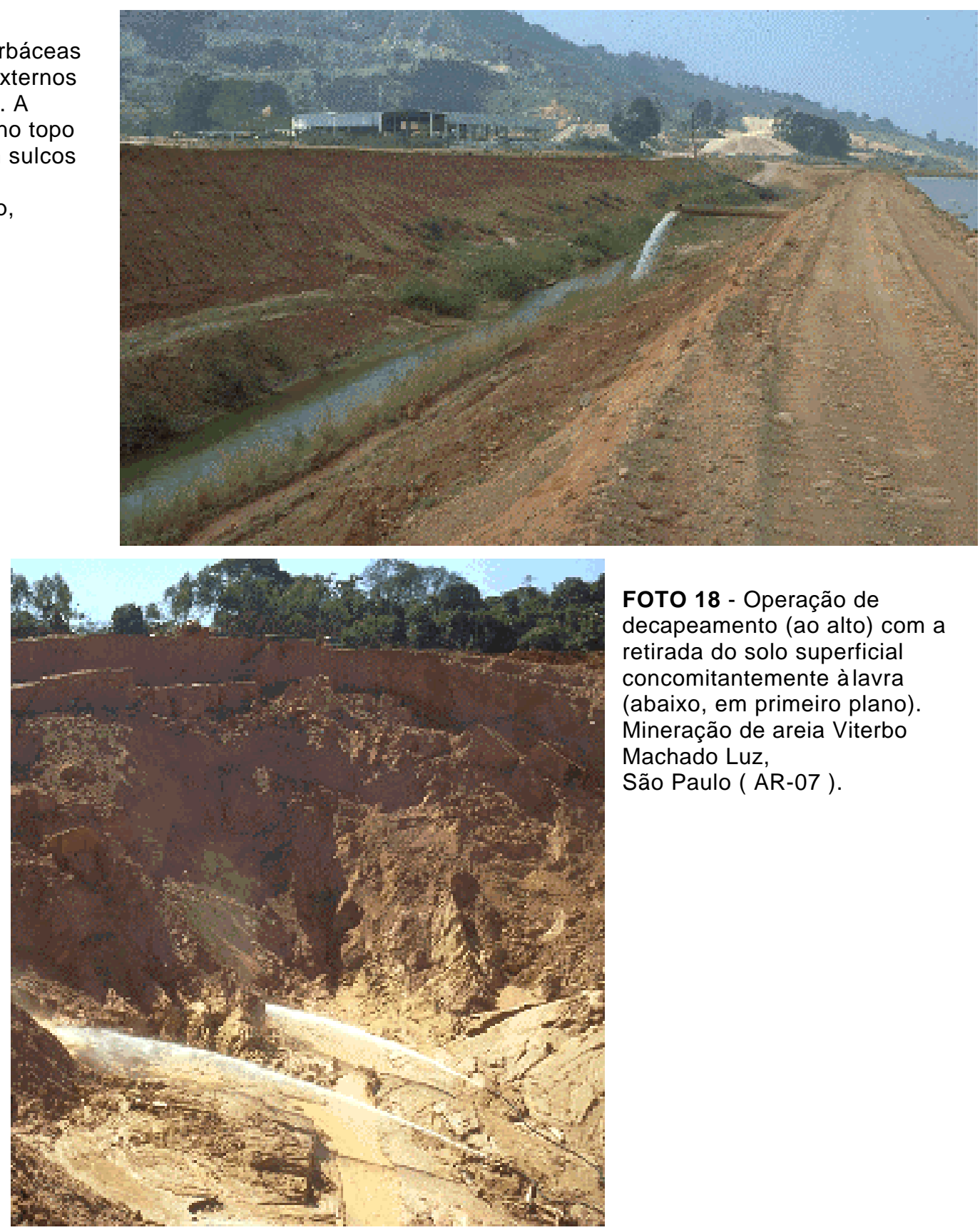

FOTO 18 - Operação de decapeamento (ao alto) com a retirada do solo superficial concomitantemente à lavra (abaixo, em primeiro plano). Mineração de areia Viterbo Machado Luz,

São Paulo ( AR-07 ). 


\subsubsection{Remoção, estocagem e utilização da camada argilosa do solo superficial}

Esta medida comprende a remoção, estocagem e utilização da camada argilosa do solo superficial ou laterítico (correspondente ao horizonte pedológico B), após a retirada da camada orgânica sobreposta (FOTO 19). A camada de solo argiloso é aplicada principalmente na construção de barragens, diques, aterros, murundus e leiras de isolamento, com a finalidade de reforçar ou altear barragens ou diques de bacias de rejeito, melhorando as condições de estabilidade. A remoção é executada de modo similar ao da camada orgânica, sendo que a aplicação do material argiloso é geralmente realizada com espalhamento e compactação (FOTOS 20 e 21). Essa camada é também utilizada como base em revegetação, especialmente quando há necessidade de volumes maiores de solo.

A estocagem é também similar ao da camada de solo orgânico, geralmente formando duas pilhas de pequeno volume (cada uma com cerca de $1,5 \mathrm{~m}$ de altura e variando entre 3 a 4 m de diâmetro), com o objetivo de evitar a esterilização do solo (especialmente no caso do solo orgânico). As pilhas são dispostas em pátios de superfície plana e com declividade muito baixa. Não é usual a cobertura, seja com palha ou lona. Em geral, a pilha permanece descoberta durante períodos curtos de tempo (FOTO 22).

Do mesmo modo que a camada orgânica, o desempenho geral desta medida tende a ser plenamente satisfatório nas minas em que, além de retirado e estocado, o solo é utilizado efetivamente no empreendimento. As incertezas estão relacionadas aos casos em que a compactação do solo argiloso não é realizada corretamente.

\subsubsection{Remoção dirigida de estéreis e prenchimento de cavas}

Esta medida compreende a remoção dirigida do material estéril, utilizando-o no preenchimento de cavas abandonadas. Tem a finalidade de obter material para recomposição da topografia do terreno, bem como reduzir o volume de minério a ser beneficiado, aumentar a vida útil das bacias de rejeito instaladas e, eventualmente, dispor de material de empréstimo para colocação no mercado.

Em minas de areia, consiste na retirada de camadas ou lentes argilosas de cor variada (roxa, marrom, amarela), presentes em meio aos sedimentos arenosos. É executada com auxílio de retroescavadeiras e exige experiência e habilidade dos operadores. Neste contexto, a medida representa uma inovação técnica na RMSP (FOTO 23).

A eficácia da medida depende dos volumes obtidos. Em minerações de argila aluvionar, a camada de estéril (0,8 a 1,0 m de turfa) retirada na operação de decapeamento, é utilizada com outros materiais no preenchimento parcial de cavas abandonadas (FOTO 24). 


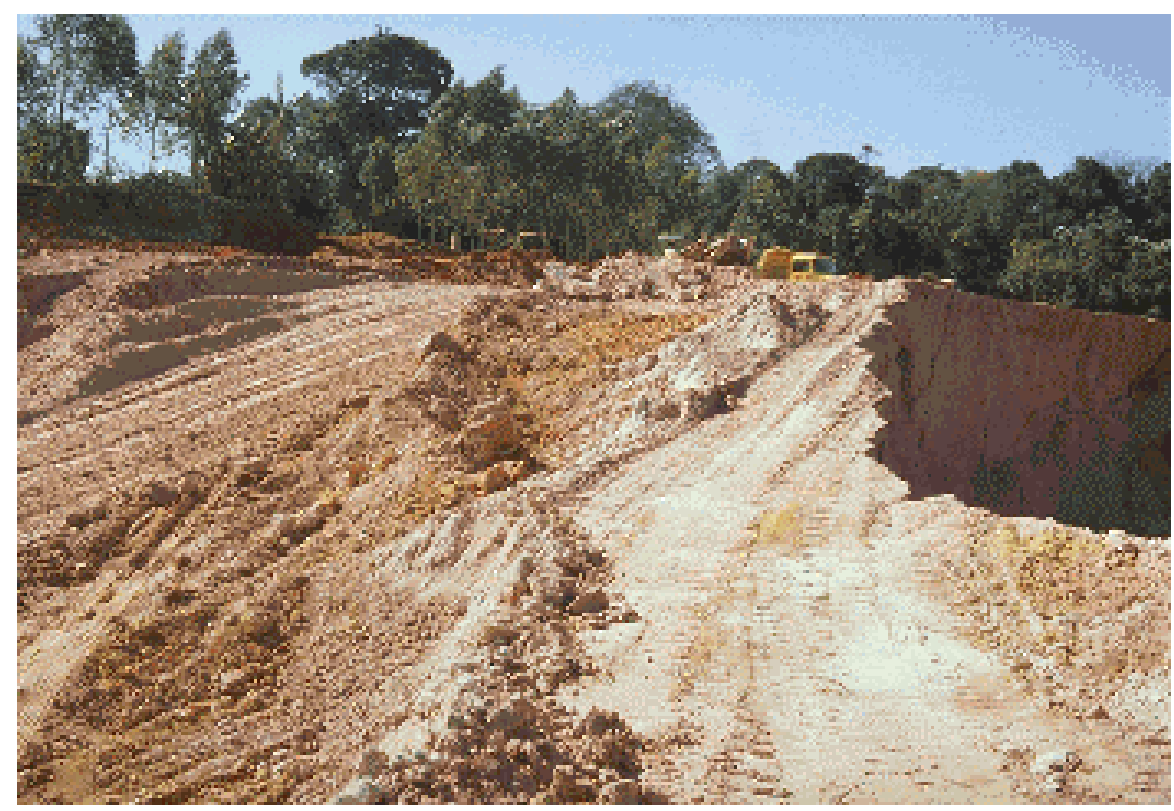

FOTO 19 - Detalhe da foto anterior, com a retirada das camadas orgânica e argilosa do solo superficial (mais escuras) e exposição do material arenoso a ser lavrado (mais claro), cuja frente de desmonte se encontra próxima (à direita).

Mineração de areia Viterbo

Machado Luz,

São Paulo ( AR-07).

FOTO 20 - Transporte e descarga do solo superficial argiloso (laterítico; horizonte pedológico B) para alteamento e reforço de barragem de rejeito. Mineração de areia Viterbo Machado Luz,

São Paulo ( AR-07).
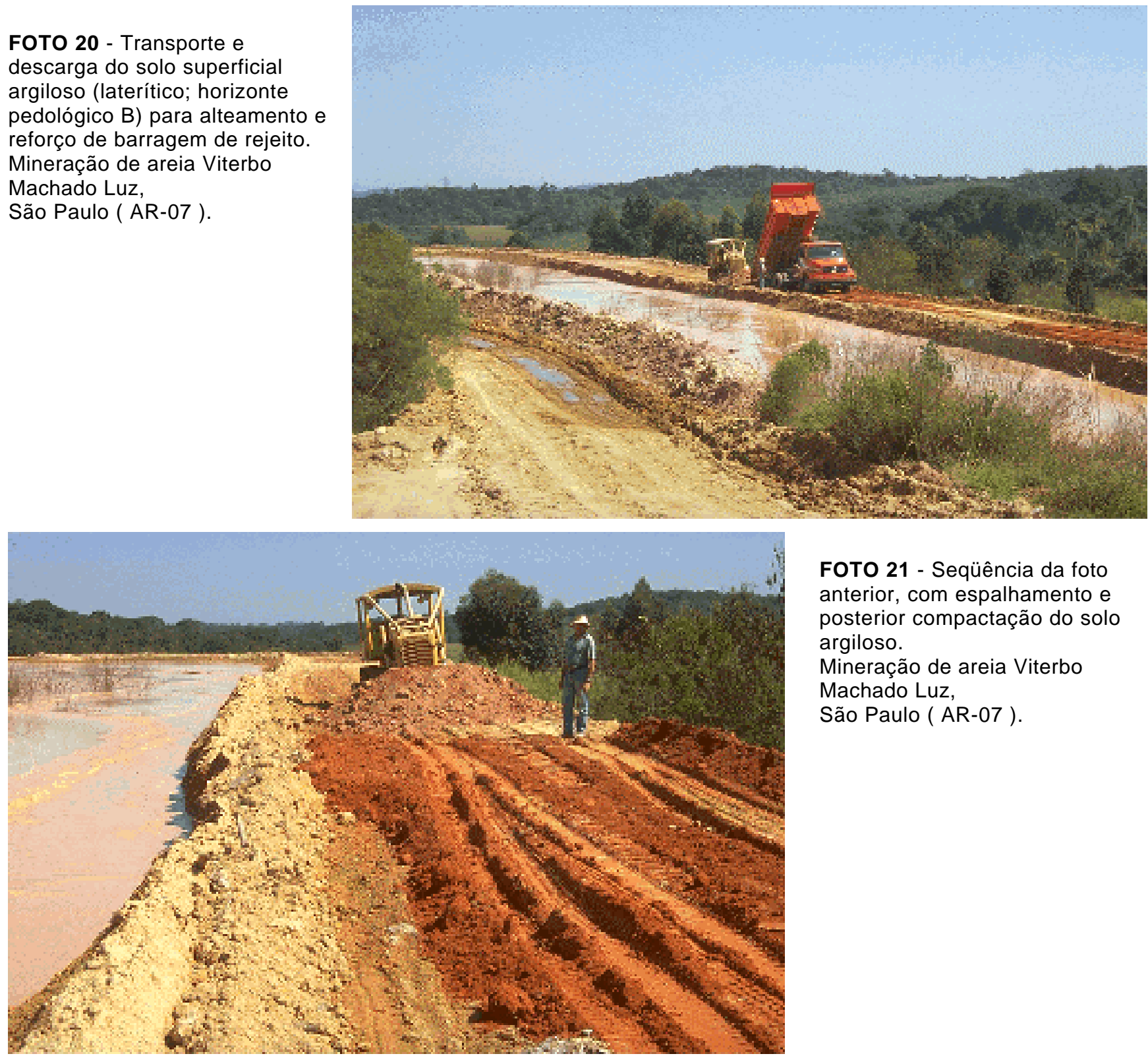

FOTO 21 - Seqüência da foto anterior, com espalhamento e posterior compactação do solo argiloso.

Mineração de areia Viterbo Machado Luz,

São Paulo ( AR-07). 


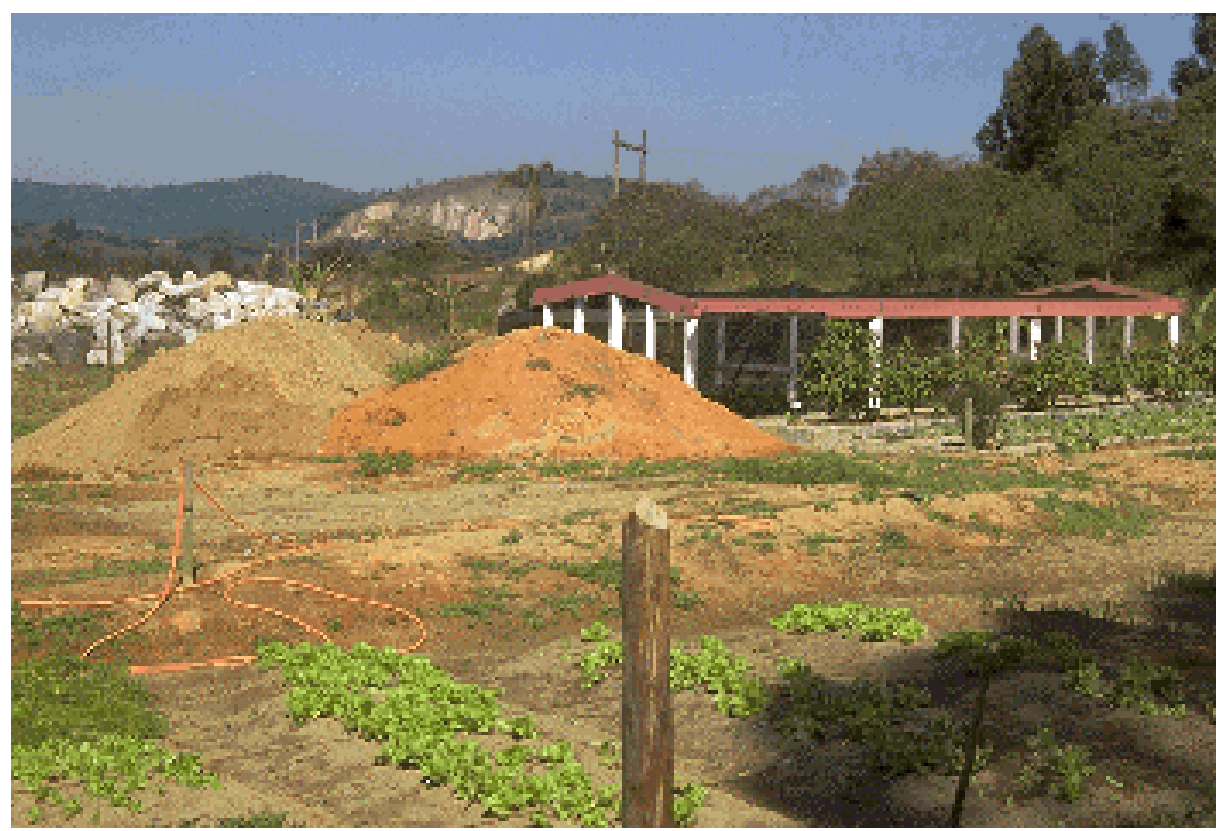

FOTO 22 - Pilhas de estocagem das camadas de solo orgânico (marrom) e argiloso

(avermelhado), junto a viveiro de mudas.

Mineração de areia Viterbo

Machado Luz,

São Paulo ( AR-07).

FOTO 23 - Retirada dirigida de camada estéril (argila). Mineração de areia Caravelas, Mogi das Cruzes ( AR-01).
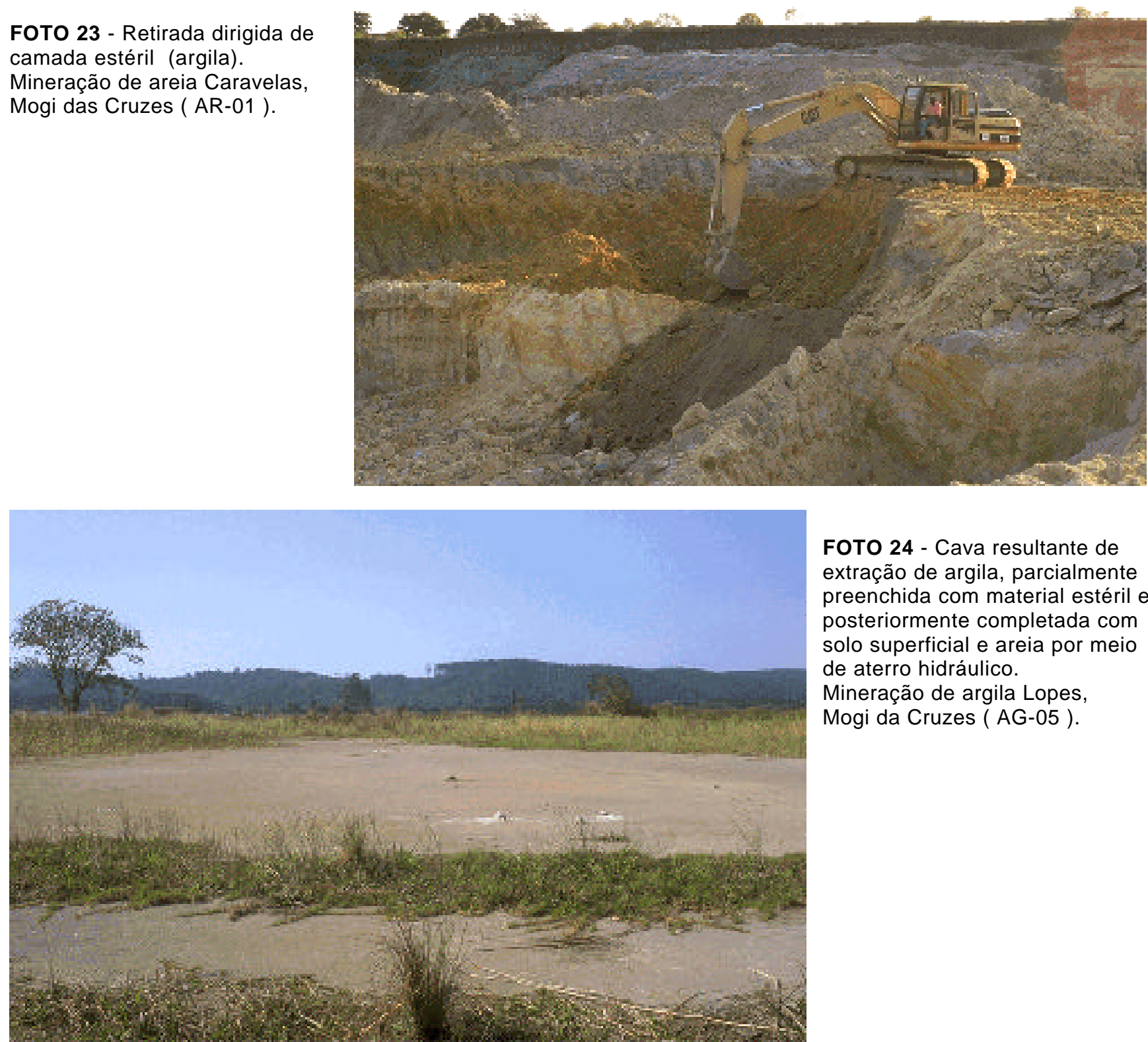

FOTO 24 - Cava resultante de extração de argila, parcialmente preenchida com material estéril e posteriormente completada com solo superficial e areia por meio de aterro hidráulico.

Mineração de argila Lopes, Mogi da Cruzes ( AG-05). 
Os outros materiais utilizados para o preenchimento completo de cavas, tanto em minerações de areia quanto de argila, são obtidos principalmente pelo recebimento de carregamentos transportados por caminhões, contendo entulhos provenientes de obras de construção civil em andamento na circunvizinhança ou mesmo de áreas mais afastadas. Este tipo de prática revela evidente tendência no sentido de procurar resolver dois problemas ao mesmo tempo: por um lado, a falta de materiais para completar o preenchimento das cavas; e, por outro, a falta de locais para disposição de resíduos inertes provenientes de obras públicas e privadas.

No entanto, o lançamento de resíduos em cavas remanescentes não tem sido acompanhado de verificação da origem e de instituição de procedimentos de triagem dos materiais na sua recepção, bem como de uma avaliação de suas características em face da possível contaminação do subsolo e das águas subterrâneas. Assim, é comum a deposição de resíduos de naturezas diversas, provelmente provenientes de indústrias metalúrgicas, químicas e outras da região ou mesmo de lixo hospitalar (que deveria ser destinado a aterros especiais ou incineração) e de lixo doméstico (que deveria ser destinado a aterros sanitários ou usinas de compostagem), àrevelia da poluição química potencial e dos riscos ambientais decorrentes. Dada a possibilidade de ocultação, a disposição desses materiais ocorre principalmente em cavas inundadas e em planícies aluvionares, sendo, contudo, também colocados em algumas cavas secas.

Em minas de areia e argila situadas em planícies aluvionares, há exemplos em que se utilizam materiais de empréstimo, especialmente solos de alteração de rochas cristalinas (horizontes pedológicos B e C) obtidos em locais próximos às minerações. Não obstante a solução para o preenchimento da cava, este tipo de procedimento tende a transferir os problemas de recuperação para esses locais, visto que também requerem medidas de estabilização geotécnica e de revegetação.

No caso do estéril composto de turfa em minas de argila aluvionar, o material poderia ser reaproveitado na melhoria das condições do solo utilizado como base de cobertura vegetal, ou seja, no próprio processo de revegetação, o que raramente ocorre.

Em minerações de caulim, o rejeito do beneficiamento é também lançado em cavas de antigas frentes de lavra, porém em condições de $\mathrm{pH}$ baixo e em volumes extremamente insuficientes.

De modo geral, embora ainda emergente, esta medida tende a ter um desempenho satisfatório, sobretudo nas minerações em que sua implementação seja realizada de modo concomitante e sincronizado às atividades de decapeamento, lavra e disposição dos materiais de estéril e de rejeitos de beneficiamento. 


\subsubsection{Instalação de sistemas de drenagem em barragens de rejeito}

Durante sua operação, muitas barragens de rejeito desenvolvem feições erosivas (sulcos) em seus taludes externos, resultantes da ação de águas pluviais, o que representa uma ameaça à sua segurança e estabilidade. Tem, portanto, a finalidade de aumentar o coeficiente de segurança da barragem e assegurar a sua estabilização.

A medida é executada por meio de movimentação de terra, sendo comum a confecção de sistemas de drenagem baseados exclusivamente na conformação inclinada da superfície de topo da barragem, às vezes seguida de captação e desvio das águas pluviais. Em alguns casos, a medida é complementada pela revegetação dos taludes da barragem, geralmente com uso de espécies exóticas.

De modo geral, esta medida apresenta desempenho satisfatório, particularmente nos casos em que são construídos sistemas com escadas de concreto para redução da velocidade das águas pluviais e conseqüente dissipação de energia. A revegetação adota comumente espécies arbóreas exóticas, como pinheiro (FOTO 25).

\subsubsection{Reforço e revegetação em barragens de rejeito}

Esta medida consiste no espessamento e alteamento do corpo principal de barragens de rejeito afetadas por processos localizados de instabilização. Tem a finalidade de preservar a integridade da barragem, evitando que eventuais rupturas possam ocorrer e gerar danos a jusante.

O reforço é efetuado pela confecção de aterro amplo, disposto imediatamente a jusante do corpo da barragem existente e pelo lançamento e compactação de solos argilosos no topo, formando novas bermas e taludes. Em alguns casos, visando assegurar a estabilidade da barragem a longo prazo, as superfícies das bermas da estrutura de reforço são revegetadas com espécies arbóreas nativas (FOTO 26).

O desempenho dos resultados desta medida tem sido regular, embora haja casos em que sua execução sem adequada compactação do aterro favorece a infiltração e saturação em água e ameaça a estabilidade da estrutura da barragem. 




FOTO 25 - Revegetação com espécies arbóreas exóticas (pinheiro),em primeiro plano. Escada d'água de concreto no talude externo da barragem de rejeito, à direita.

Mineração de areia Ponte Alta, São Paulo ( AR-26).

FOTO 26 - Revegetação em superfície de reforço de barragem de rejeito, com uso de mudas de espécies arbóreas mudas de espécies arbóreas Viterbo Machado Luz, São Paulo ( AR-07).

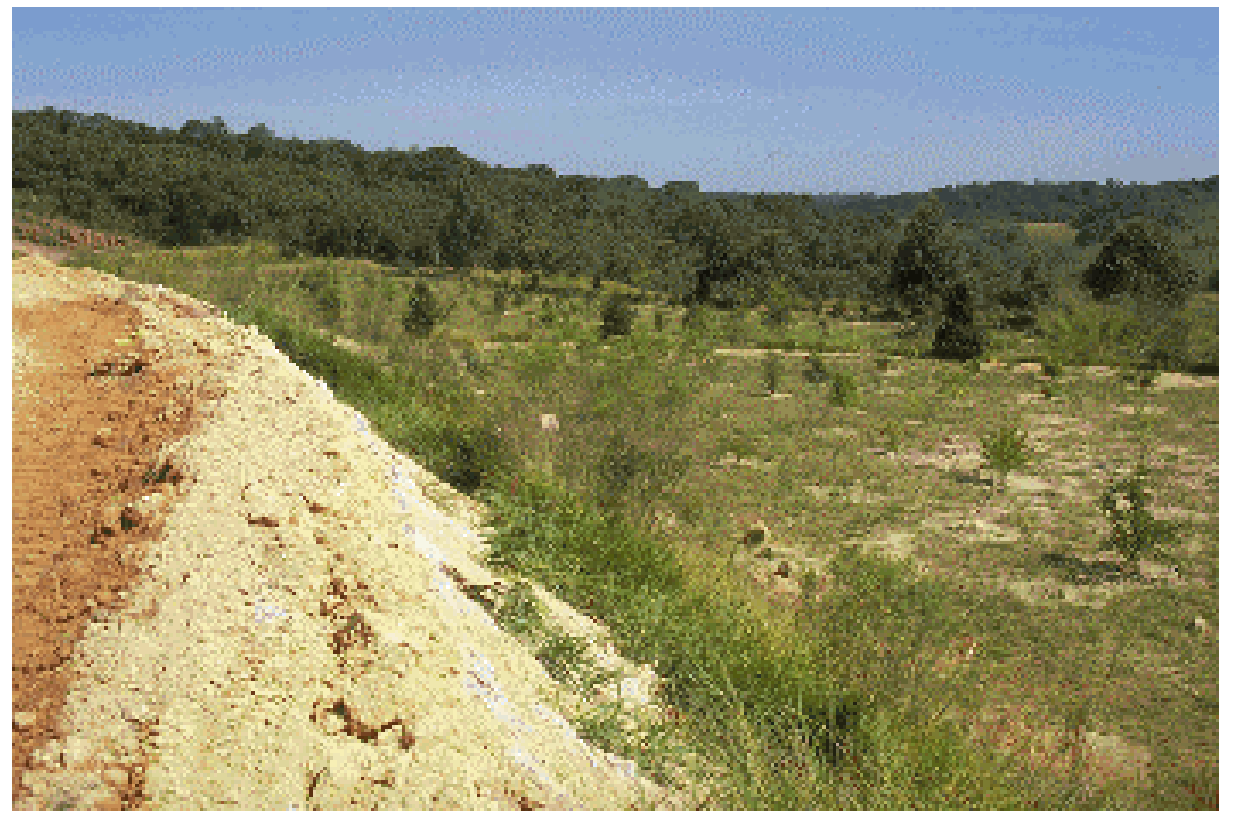




\subsubsection{Instalação de extravasores em barragens de rejeito}

Esta medida compreende a instalação ou substituição de extravasores em barragens de rejeito existentes, com a finalidade de permitir a descarga do excesso de água nos períodos de precipitação pluviométrica intensa e, assim, evitar danos ao corpo principal da barragem, inclusive sua eventual ruptura e conseqüências decorrentes. É comum em minerações de areia e de caulim em morros.

A medida é executada por meio da instalação de tubulões de concreto ou ferro, com diâmetro de cerca de $40 \mathrm{~cm}$, geralmente dispostos nas ombreiras ou porções extremas do corpo da barragem.

O desempenho desta medida é insatisfatório. Os problemas associados são vários e envolvem desde insuficiência na capacidade de vazão, visto que a maior parte dos extravasores são dimensionados empiricamente, até a indução de processos erosivos internos ("piping"), no próprio corpo da barragem. É freqüente a saturação em água da barragem de rejeito, havendo casos em que se verificam surgências na base. Não foram encontrados extravasores de superfície, construídos em alvenaria, sendo raros os casos em que há sistemas de dissipação de energia (como escadas de concreto) construídos a jusante do ponto de descarga d'água.

\subsubsection{Transposição de rejeitos de bacias de decantação para áreas lavradas}

Esta medida compreende a retirada de rejeitos acumulados em bacias de decantação e sua transposição para áreas lavradas. Ocorre particularmente em minerações de areia situadas no contexto de sedimentos terciários e relevo colinoso. Tem sido motivada pela crescente dificuldade de ampliação ou abertura de novas bacias de rejeitos, seja por razões econômicas ou por problemas legais, com a conseqüente necessidade de liberar volume útil nas bacias existentes. Como decorrência, transferem-se os rejeitos para áreas lavradas, de modo a auxiliar a estabilização desses locais. É, no contexto da região, uma medida de inovação técnica.

É executada por meio de bombeamento hidráulico, condução em mangueiras e disposição em áreas lavradas (FOTO 27), formando uma sucessão de novas e pequenas bacias de rejeito, submetidas às medidas de estabilização das barragens e revegetação espontânea (gramíneas) da superfície final (FOTO 28).

A medida tem se mostrado bastante eficaz e o desempenho, já satisfatório nos casos em que é praticada há algum tempo, tende a melhorar com o desenvolvimento e a consolidação da vegetação instalada. 


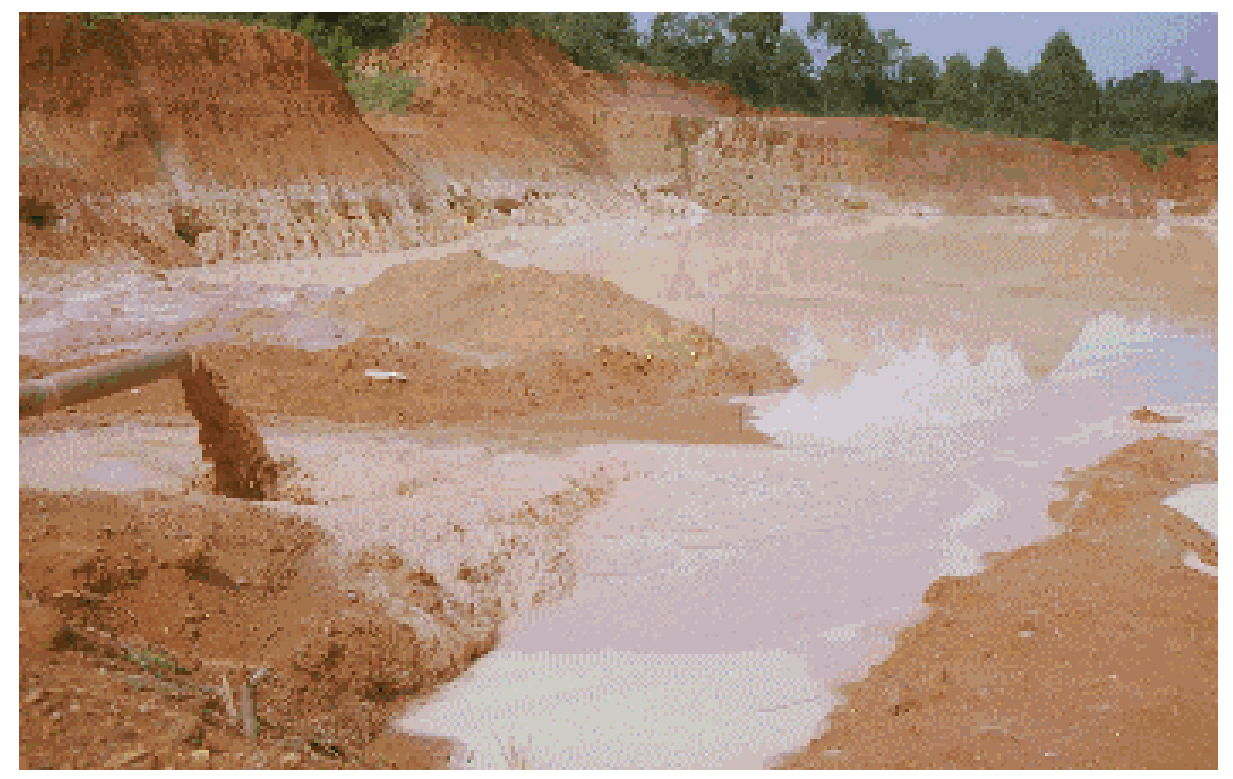

FOTO 27 - Transposição de rejeitos dispostos em bacias de rejeito e lançamento em áreas lavradas por meio de bombeamento hidráulico.

Mineração de areia Floresta Negra,

Guarulhos ( AR-15 ).

FOTO 28 - Novas bacias de rejeito instaladas em antiga frente de lavra, resultantes de transposição por bombeamento hidráulico. Mineração de areia Floresta Negra, Guarulhos ( AR-15 ).

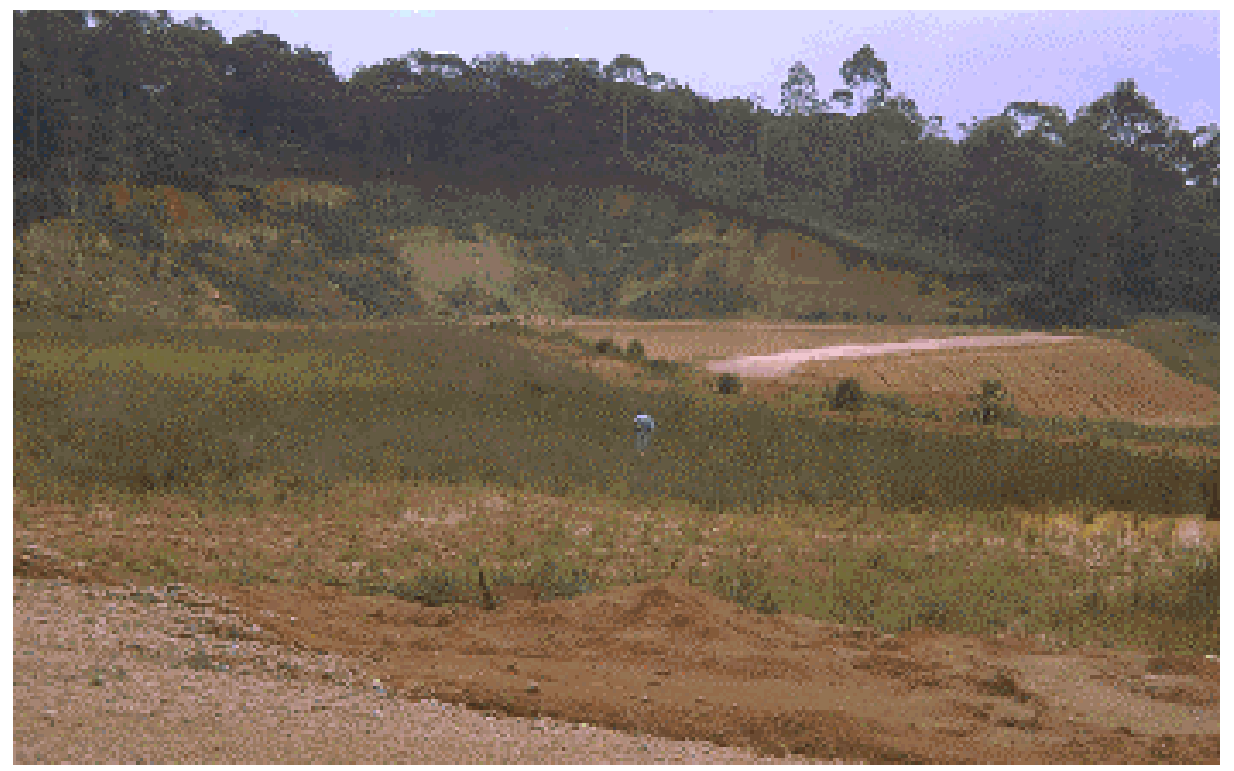




\subsubsection{Instalação de sistemas de drenagem e retenção de sedimentos}

Esta medida compreende a instalação de sistemas de drenagem para captação e desvio das águas pluviais na área do empreendimento, bem como para retenção dos sedimentos mobilizados. Tem a finalidade de atenuar o potencial erosivo das águas pluviais, evitando que os sedimentos transportados atinjam cursos d'água situados a jusante e produzam assoreamento, entre outros efeitos associados àperda de qualidade das águas.

A execução desta medida requer a instalação de sistemas de drenagem adicionais, envolvendo a construção e interligação de novas canaletas longitudinais e transversais. Os sistemas são instalados nas frentes de lavra, unidades de beneficiamento e áreas de disposição de bota-foras. Compreendem, ainda, caixas intermediárias de sedimentação e dissipação de energia cinética, confeccionadas em alvenaria e estruturas de concreto (geralmente com cerca de $2 \times 4 \times 2 \mathrm{~m}$, tendo a maior dimensão no comprimento), canaletas perimetrais dispostas em toda a área da mineração e, eventualmente, bacias ou lagos pequenos de decantação construídos no limite máximo a jusante da área da mineração. Nestes últimos, as bacias ou lagos apresentam sistemas de extravasores, visando eliminar o excesso de água em momentos de chuvas intensas (FOTOS 29 a 38).

Há muitos casos em que o sistema de drenagem é executado diretamente no solo, particularmente em vias de circulação interna. Nestas situações, são freqüentes e notáveis os problemas de erosão acelerada, muitas vezes formando ravinas com profundidades da ordem de alguns metros, denotando, ao contrário da finalidade da medida, uma maior contribuição na produção de sedimentos. Outra dificuldade está associada a locais de descarga d' água sem revestimento, tornando-os nova fonte produtora de sedimentos.

O desempenho desta medida é melhor nos sistemas que adotam canaletas revestidas, tanto no seu leito quanto nas laterais. Porém, o desempenho depende fundamentalmente de periódica conservação e limpeza das canaletas, bem como da retirada dos sedimentos e demais materiais acumulados a cada período chuvoso. Em geral, nos empreendimentos em que os sistemas são compostas por estruturas de concreto, o desempenho tende a ser satisfatório. Todavia, tem sido comum a presença de canaletas continuamente entulhadas por sedimentos predominantemente arenosos e de depósitos de assoreamento situados em cursos d'água a jusante de minerações. No caso das canaletas, o problema se verifica especialmente em períodos imediatamente subseqüentes à ocorrência de episódios de precipitação pluviométrica intensa. Isto sugere a existência de problemas operacionais e de manutenção, os quais podem prejudicar o funcionamento da medida, tornando-a pouco eficaz e com desempenho regular a insatisfatório. 


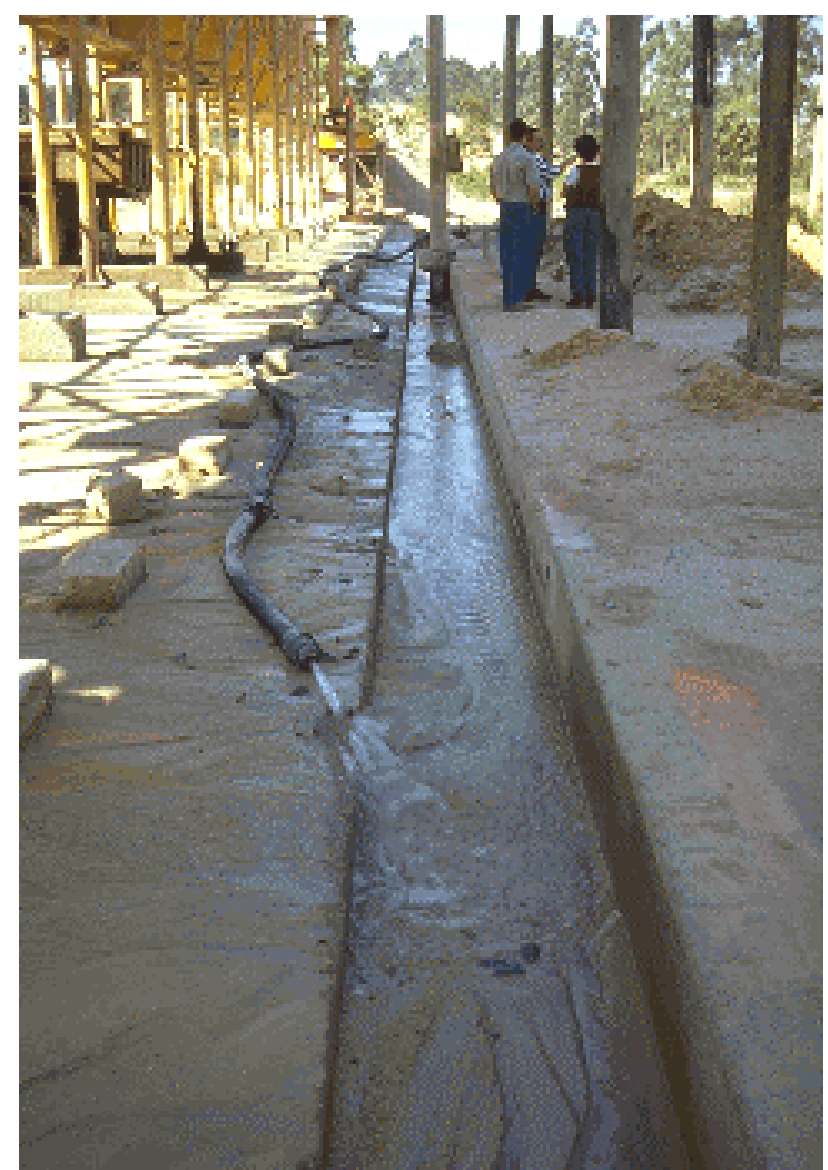

FOTO 29 - Canaleta de

drenagem revestida de concreto para captação e condução de água e retenção de sedimentos provenientes da unidade de beneficiamento.

Mineração de areia Viterbo Machado Luz,

São Paulo ( AR-07).

FOTO 30 - Tubulação e escadas de concreto para condução das águas pluviais em área de bota fora.

Pedreira Embu, Embu ( BT-02 ).

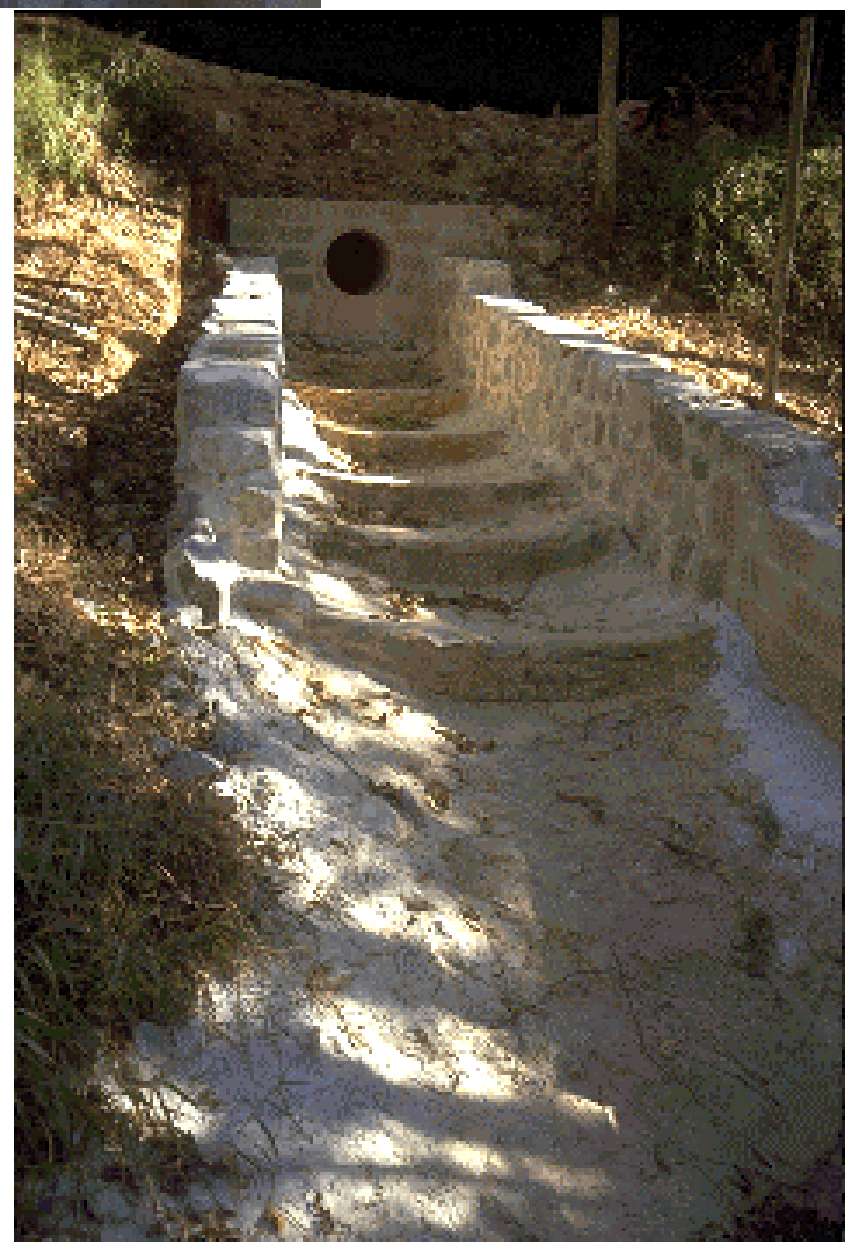




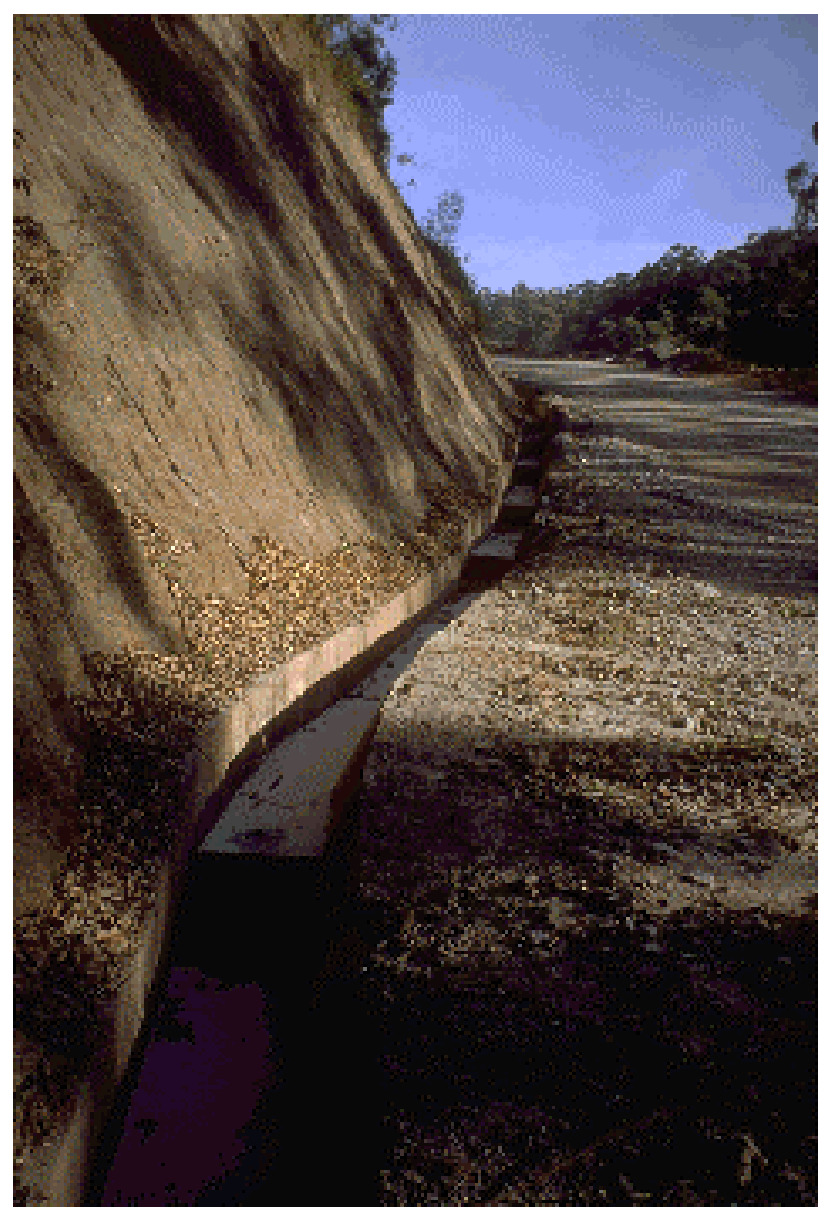

FOTO 31 - Canaletas de concreto perimetrais àárea da mineração, para captação e condução das águas pluviais. Pedreira Embu, Embu ( BT-02).

FOTO 32 - Tanque de sedimentação construído a jusante do sistema de drenagem da área da mineração, exibindo notável acúmulo de sedimentos. Pedreira Alvenaria, Mairiporã ( BT-13 ).

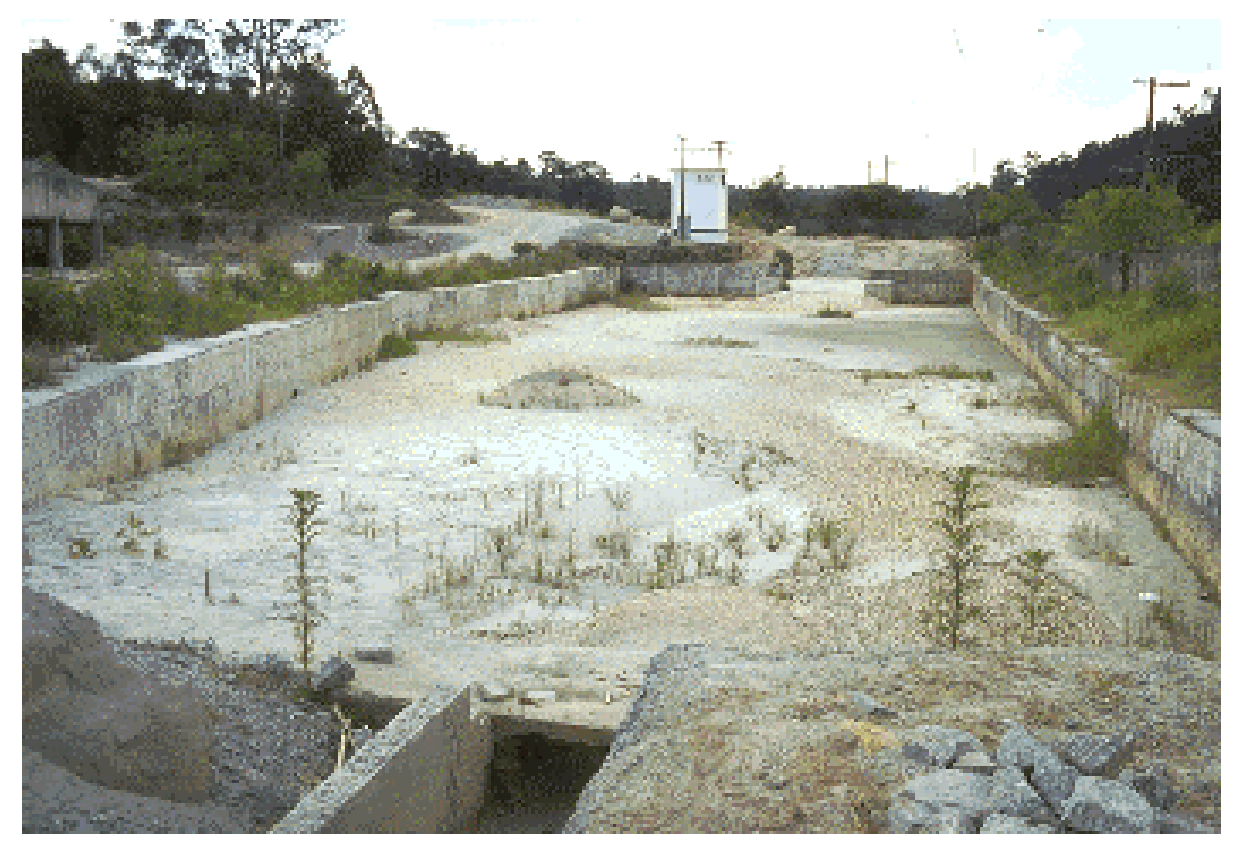




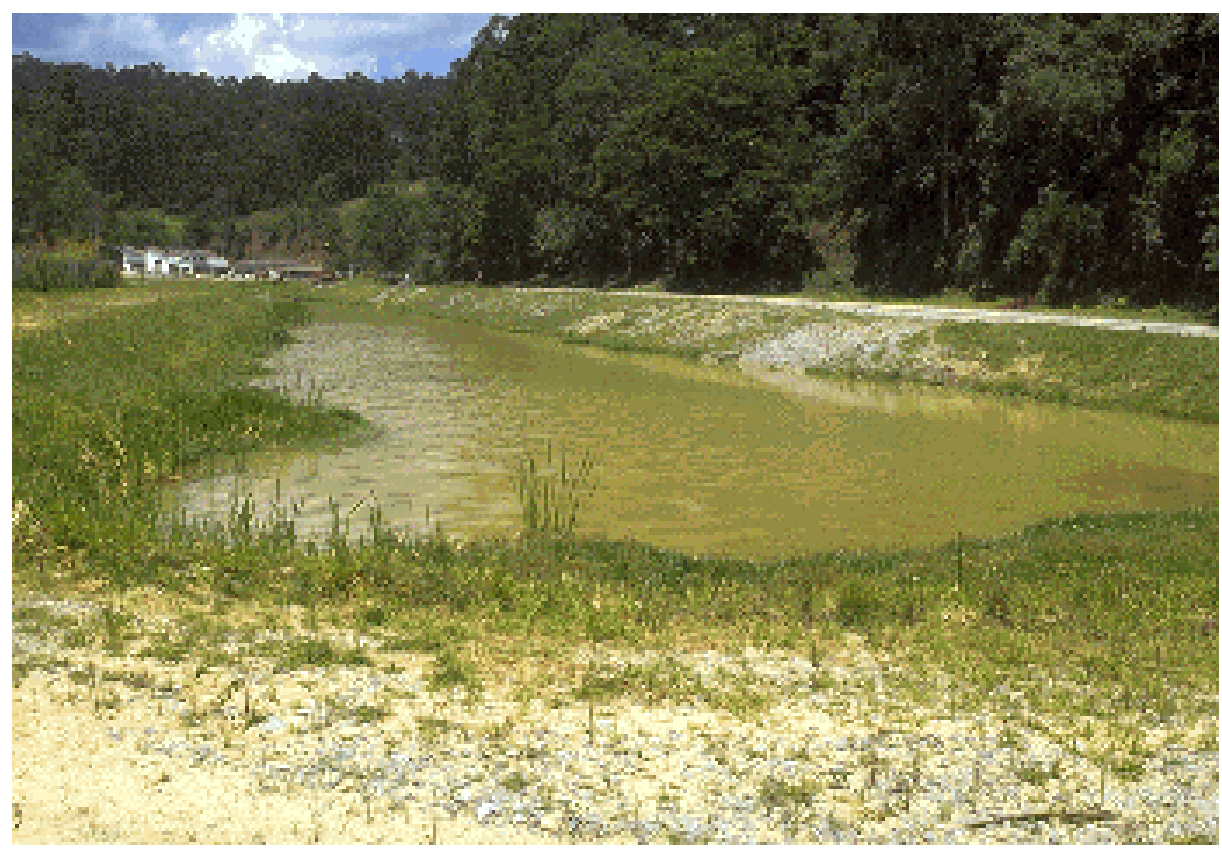

FOTO 33 -Lago artificial construído a jusante do empreendimento, para retenção de sedimentos provenientes da área da mineração.

Pedreira Cantareira,

Mairiporã ( BT-14 ).

FOTO 34 - Sistema de barramento com uso de material de bota-fora, construído em bermas e taludes a jusante da área de lavra, para retenção de sedimentos. Mineração de caulim MM,

Embu-Guaçu ( KI-06 ).

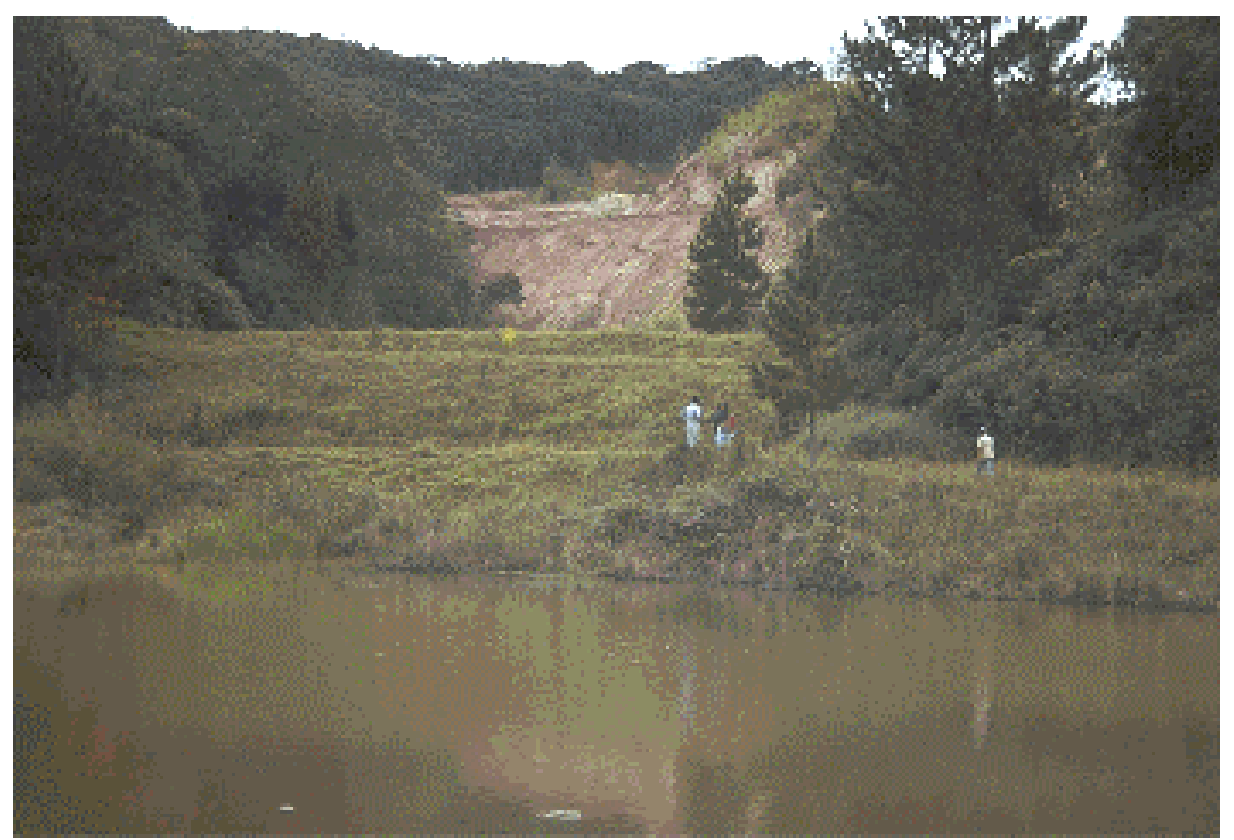




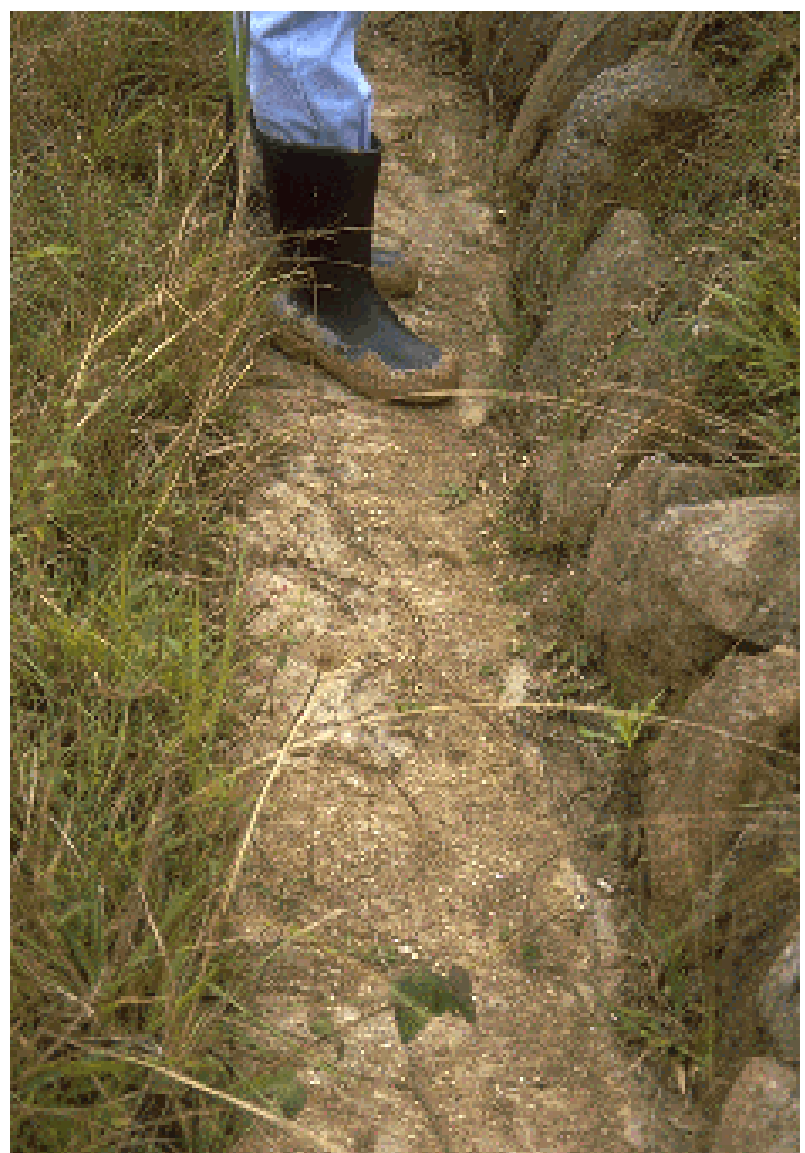

FOTO 35 - Detalhe de canaleta revestida em pedra, instalada entre a berma e o talude, do sistema de barramento descrito na foto anterior.

Mineração de caulim MM, Embu-Guaçu ( KI-06 ).

FOTO 36 - Barragem de terra denotada pelo plantio alinhado de espécies arbóreas exóticas, construída para reter os sedimentos provenientes de pilha de bota-fora.

Pedreira Itapiserra,

Itapecerica da Serra ( BT-24 ).

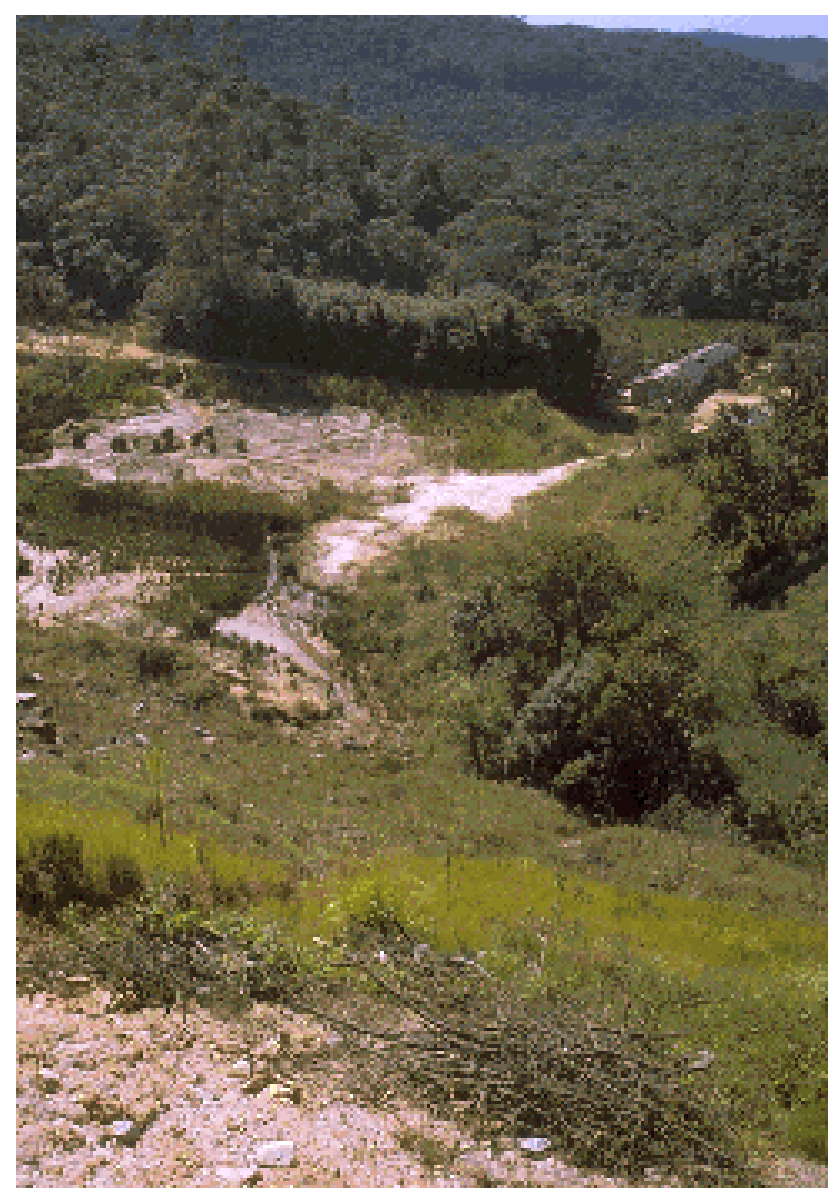




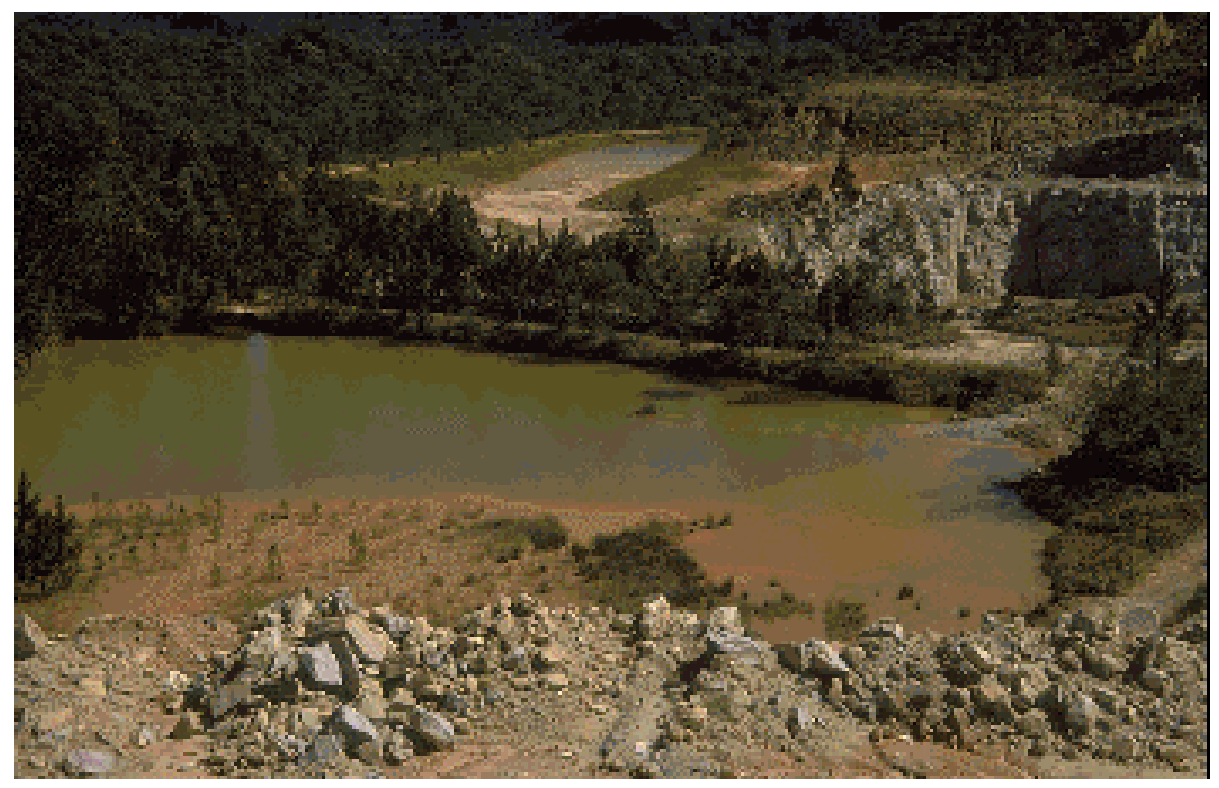

FOTO 37 - Sucessão de pequenos lagos para retenção de sedimentos provenientes de pilha de bota-fora. Pedreira Itapiserra, Itapecerica da Serra ( BT-24 ).

FOTO 38 - Assoreamento em um dos lagos construídos para retenção de sedimentos provenientes de pilha de botafora. Pedreira Itapiserra, Itapecerica da Serra ( BT-24 ).

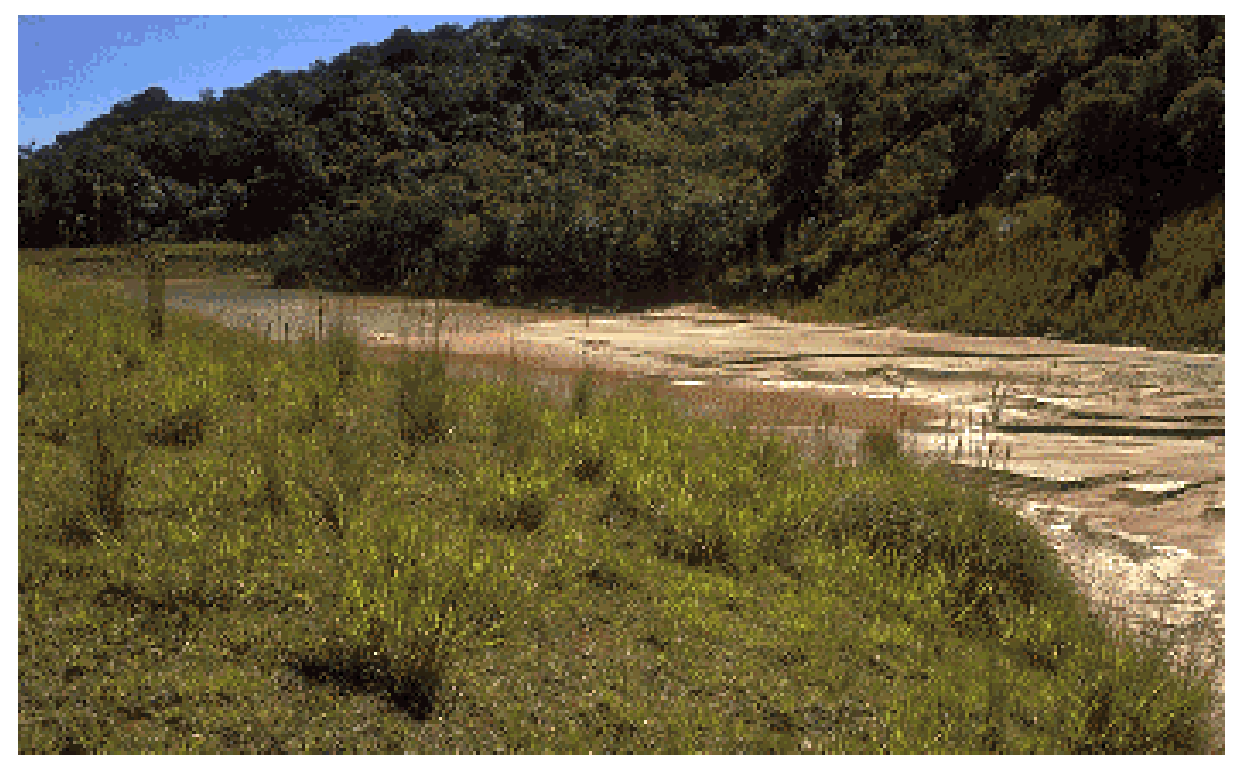




\subsubsection{Construção e estabilização de bota-foras}

Encontrada principalmente em pedreiras, esta medida compreende a construção organizada de bota-foras ou corpos de estéril em pilhas de grande porte, seguida de cobertura com solo e revegetação. Tem a finalidade de confinar e estabilizar os grandes volumes de estéril gerados, bem como os blocos rochosos que não se enquadram nos requisitos de produção.

É executada pelo carregamento do material em caminhões e lançamento em encostas de morros ou morrotes, formando bancadas de dimensões variadas ou em talude único. Em bota-foras de bancadas maiores, é comum a revegetação por meio de espécies arbóreas (geralmente exóticas, como eucalipto) nos taludes e herbáceas nas bermas (FOTOS 39 a 42).

Nas pilhas de menor porte, a revegetação é realizada exclusivamente com uso de espécies herbáceas (gramíneas forrageiras, colocadas em placas ou em touceiras), o mesmo ocorrendo no caso de talude único, sendo comum a presença de sulcos que evidenciam a instalação de processos erosivos (FOTOS 43 a 45).

Às vezes, a revegetação das bermas e taludes é acompanhada de medidas de correção da acidez do solo (calagem) e introdução de matéria orgânica (composto de lixo urbano, peneirado ou não). A superfície de topo dos bota-foras tem sido também objeto de revegetação, porém predominantemente com uso de espécies arbóreas nativas ou exóticas (FOTOS 46 e 47).

É incipiente o uso de técnicas que tendem a conferir maior segurança e estabilidade aos bota-foras, como o remodelamento da geometria das pilhas, visando seu rebaixamento e espalhamento. Isto seria executado adequadamente apenas se previsto no início da disposição, envolvendo a escavação dos solos superficiais que circundam a área que se destina à pilha de estéril e sua disposição lateral, espalhamento dos materiais com equipamentos de terraplenagem, recobrimento com os solos escavados e, finalmente, revegetação. Contudo, a dificuldade maior para a execução plena deste tipo de procedimento tem sido a disponibilidade de áreas planas e de extensões compatíveis com os volumes demandados.

O desempenho desta medida nas pilhas de talude único é insatisfatório e extremamente incerto. Isto tem ocorrido sobretudo em face da comum inexistência ou insuficiência de sistemas de drenagem e na ausência de cobertura vegetal, o que coloca em risco a estabilidade da massa de estéril. No caso dos bota-fora em encostas, quando construídos de maneira organizada e com sistemas de drenagem eficientes, o desempenho tende a ser satisfatório. 


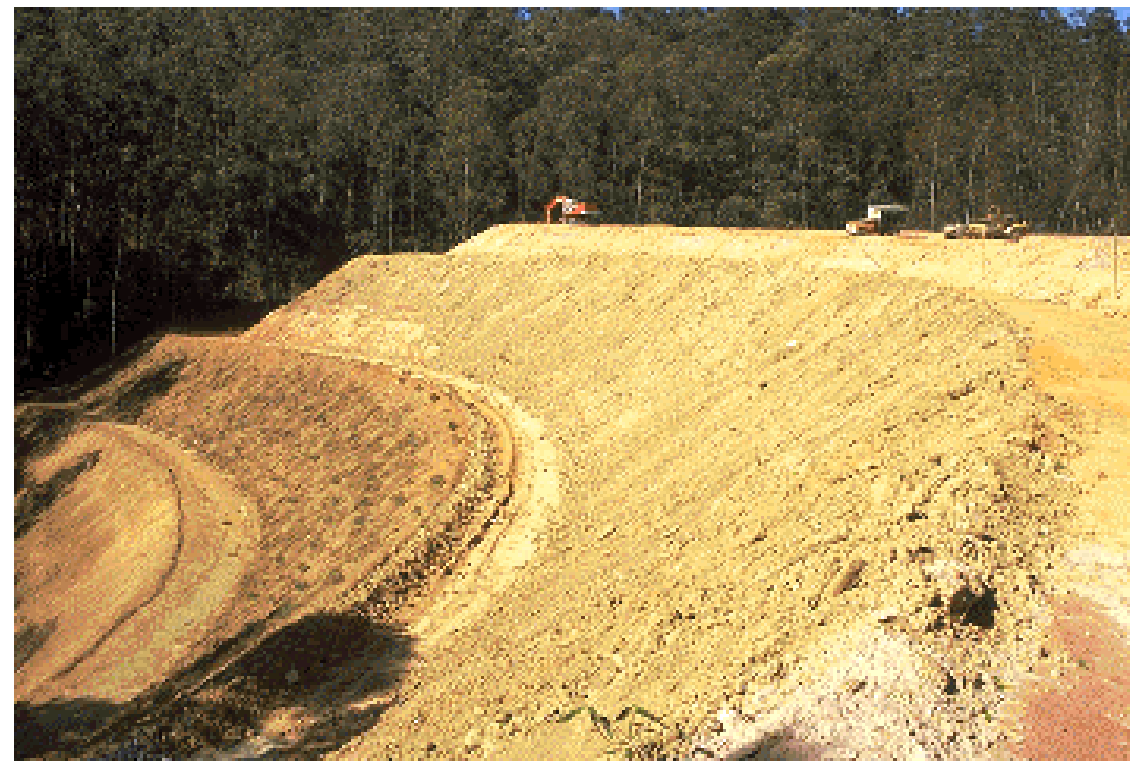

FOTO 39 - Construção de botafora em bermas e taludes, contendo sistema de drenagem e revegetação.

Pedreira Embu,

Embu ( BT-02 ).

FOTO 40 - Revegetação dos taludes de bota-fora com mudas de espécies arbóreas exóticas (eucalipto).

Pedreira Embu, Embu ( BT-02).
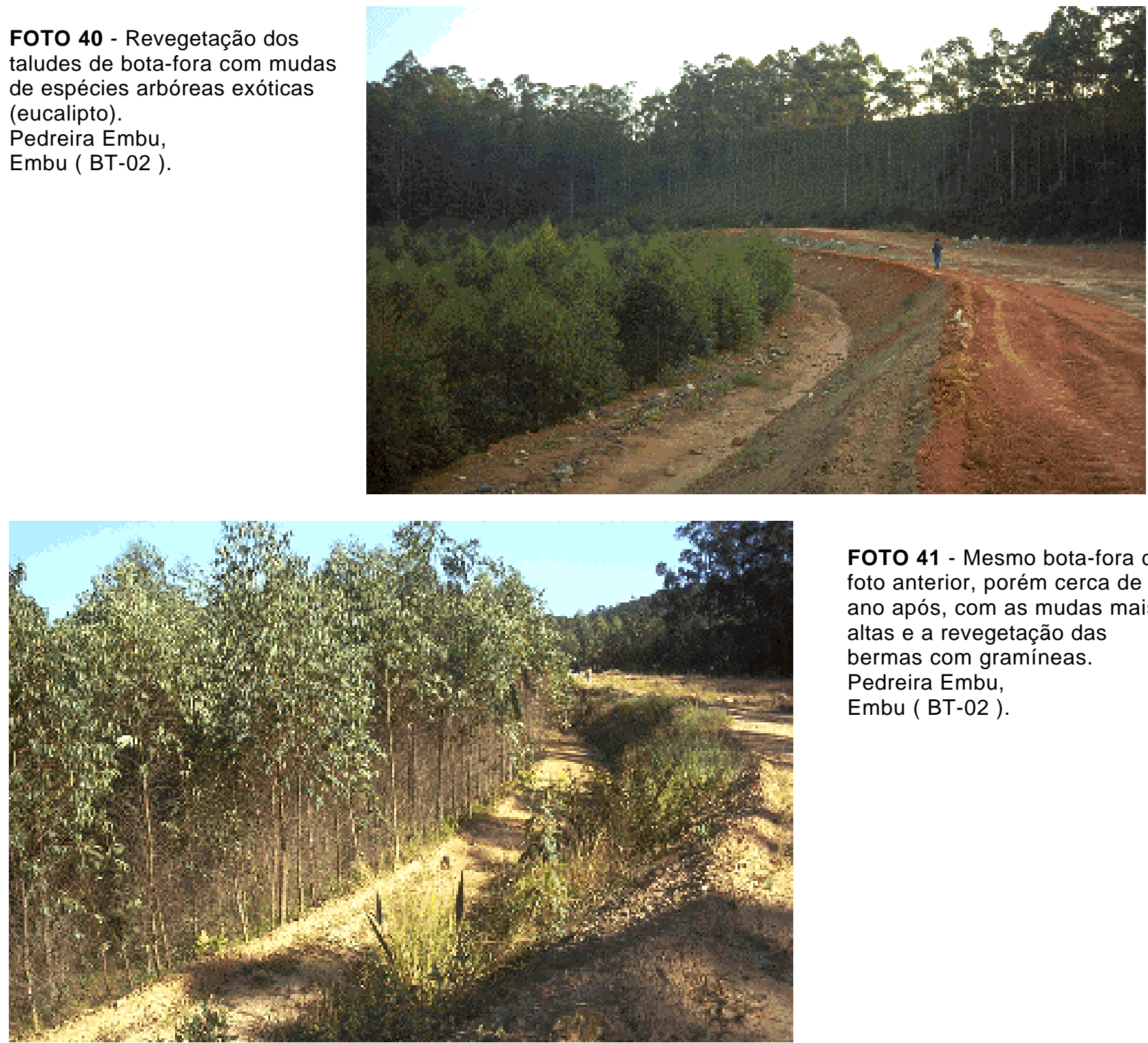

FOTO 41 - Mesmo bota-fora da foto anterior, porém cerca de um ano após, com as mudas mais altas e a revegetação das bermas com gramíneas.

Pedreira Embu,

Embu ( BT-02). 


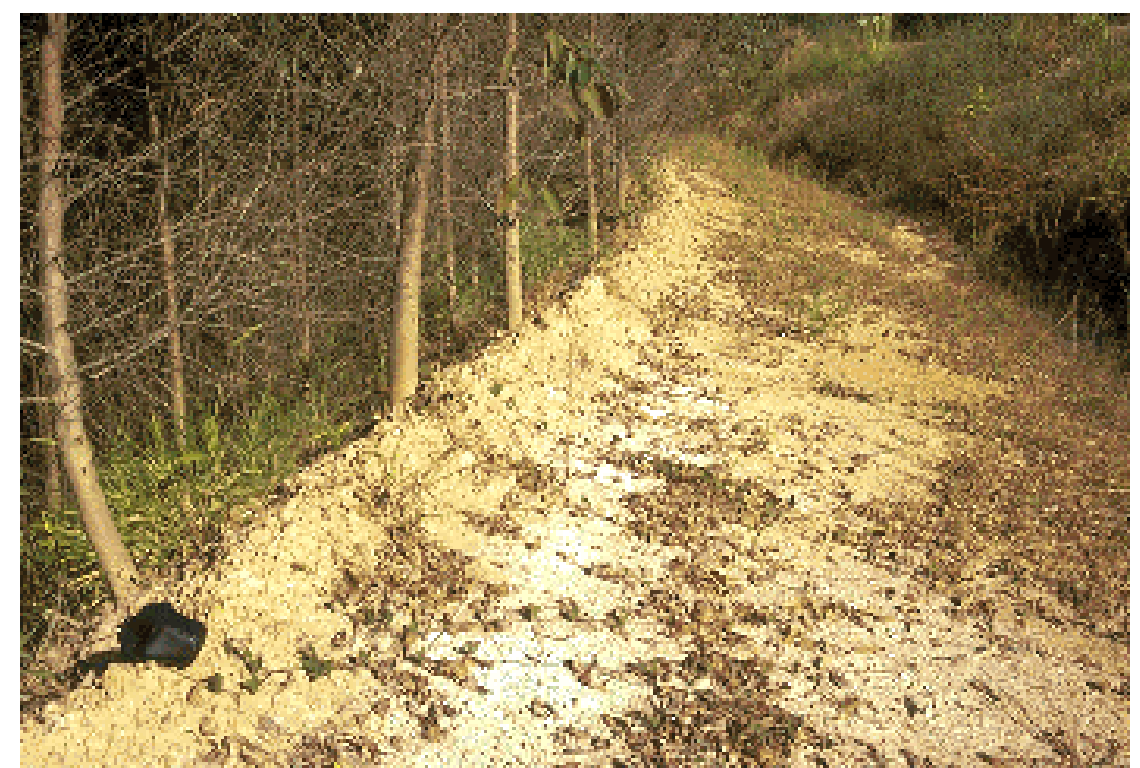

FOTO 42 - Mesmo local da foto anterior, destacando os murundus ou leiras de isolamento e a inclinação da superfície da berma. Pedreira Embu,

Embu ( BT-02 ).

FOTO 43 - Plantio de herbáceas na porção superior de talude do corpo de bota-fora, ressaltandose os sulcos erosivos na porção inferior.

Pedreira Mariutti , Itapecerica da Serra ( BT-12).
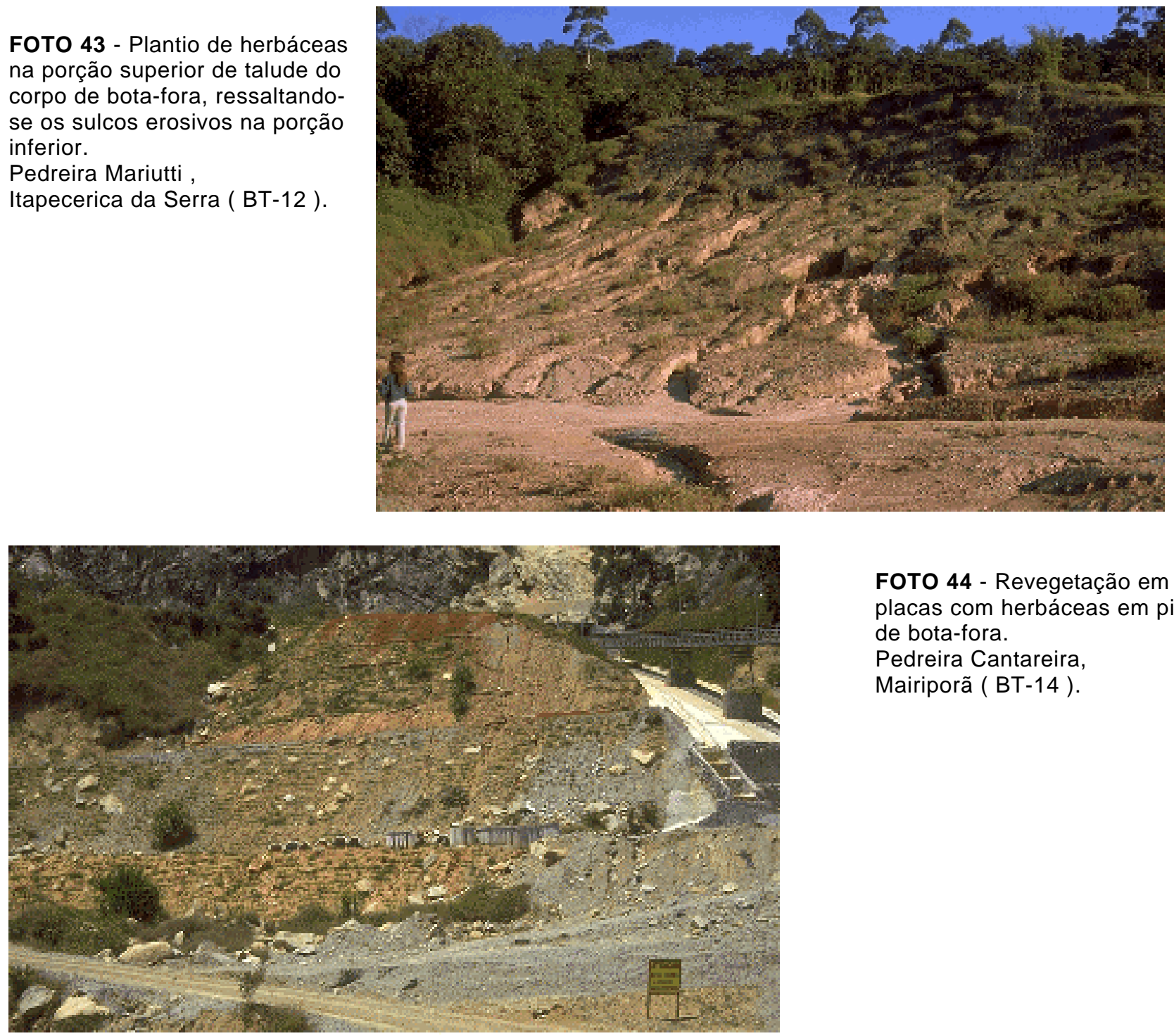

FOTO 44 - Revegetação em placas com herbáceas em pilha de bota-fora.

Pedreira Cantareira,

Mairiporã ( BT-14 ). 


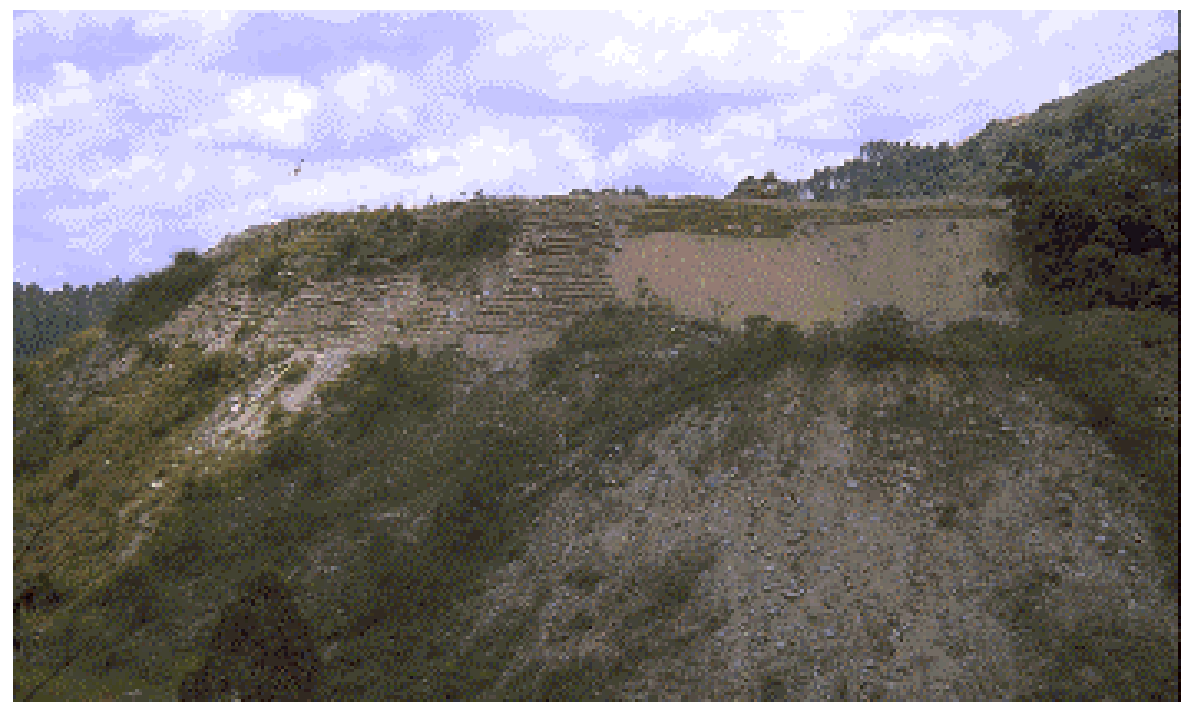

FOTO 45 - Revegetação de talude de bota fora com uso progressivo de espécies herbáceas plantadas manualmente.

Pedreira Panorama,

São Paulo ( BT-19 ).

FOTO 46 - Revegetação da superfície de topo da pilha de bota-fora, com o plantio direto de mudas de espécies arbóreas nativas e exóticas, mas sem colocação de solo superficial. Pedreira Itapiserra, Itapecerica da Serra ( BT-24).
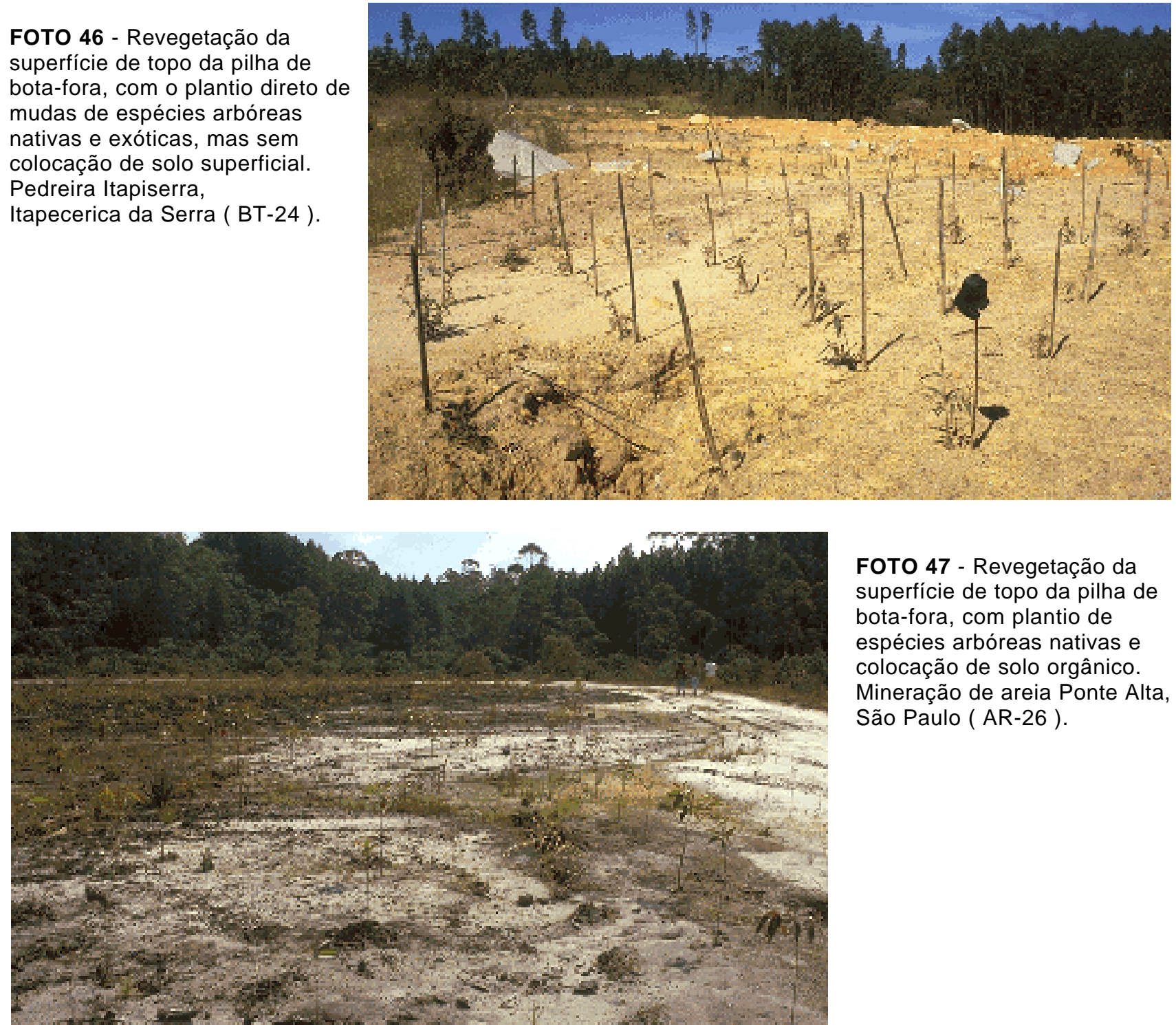

FOTO 47 - Revegetação da superfície de topo da pilha de bota-fora, com plantio de espécies arbóreas nativas e colocação de solo orgânico. Mineração de areia Ponte Alta, São Paulo ( AR-26 ). 


\subsubsection{Retenção e coleta de óleos e graxas}

Esta medida compreende as instalações que visam reter e coletar resíduos provenientes das áreas de oficinas de manutenção e lavagem de máquinas, veículos e equipamentos e de manuseio de combustíveis e lubrificantes, especialmente óleos e graxas. Tem a finalidade de evitar que os resíduos gerados atinjam o solo ou corpos d'água situados a jusante das instalações.

A execução envolve a construção dirigida de valas ou canaletas revestidas com concreto, acopladas a sistema de filtros e caixas de brita, de modo a separar os óleos e graxas gerados, permitindo sua coleta e eventual reutilização na lubrificação de máquinas e veículos do próprio empreendimento ou de outros (FOTOS 48 e 49).

O desempenho tende a ser satisfatório, embora sejam notáveis alguns sistemas restritos e que expressam apenas um efeito demonstrativo, dada a evidente desproporção entre seu dimensionamento e o porte das máquinas e veículos presentes na mina. Em nível do empreendimento, a principal deficiência reside na realização de operações de manutenção de máquinas e manuseio de combustíveis em locais cuja geração rotineira de resíduos não contempla a condução para o sistema de filtros e caixas.

\subsubsection{Revegetação de taludes em acessos e vias internas}

Esta medida compreende o plantio de espécies vegetais herbáceas em taludes de corte existentes em acessos e vias de circulação internas. Tem a finalidade de atenuar o impacto visual, melhorando o ambiente interno de trabalho, bem como reduzir o aporte de sedimentos ao sistema de drenagem existente.

A execução é geralmente através de técnicas de hidrossemeadura ou de plantio manual de espécies herbáceas, estas últimas por meio de colocação de gramíneas em placas ou touceiras (FOTOS 50 a 53).

É raro o uso de espécies arbóreas em taludes, sendo encontradas comumente nos empreendimentos que apresentam terrenos planos situados æ̀s margens de vias internas (FOTO $54)$.

O desempenho desta medida tende a ser regular a satisfatório na maior parte dos casos, destacando-se os empreendimentos que utilizam espécies herbáceas forrageiras nos taludes, visto que, com isso, tendem a obter melhores resultados. 


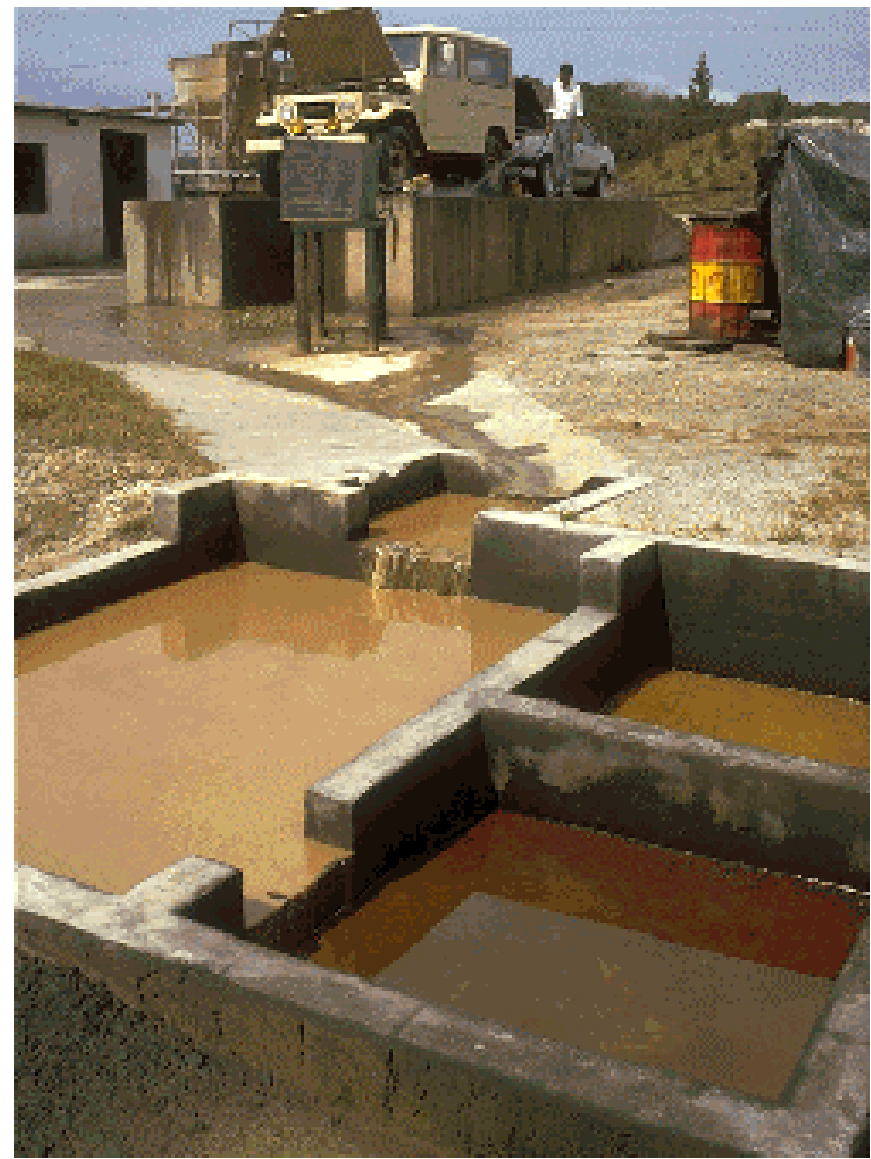

FOTO 48 - Sistema de tanque de retenção e separação de óleos e graxas provenientes de manutenção e limpeza de equipamentos e máquinas. Mineração de areia Ponte Alta, São Paulo ( AR-26 )

FOTO 49 - Sistema de tanque e caixa de brita para retenção de óleos e graxas.

Mineração de areia Viterbo Machado Luz,

São Paulo ( AR-07 ).

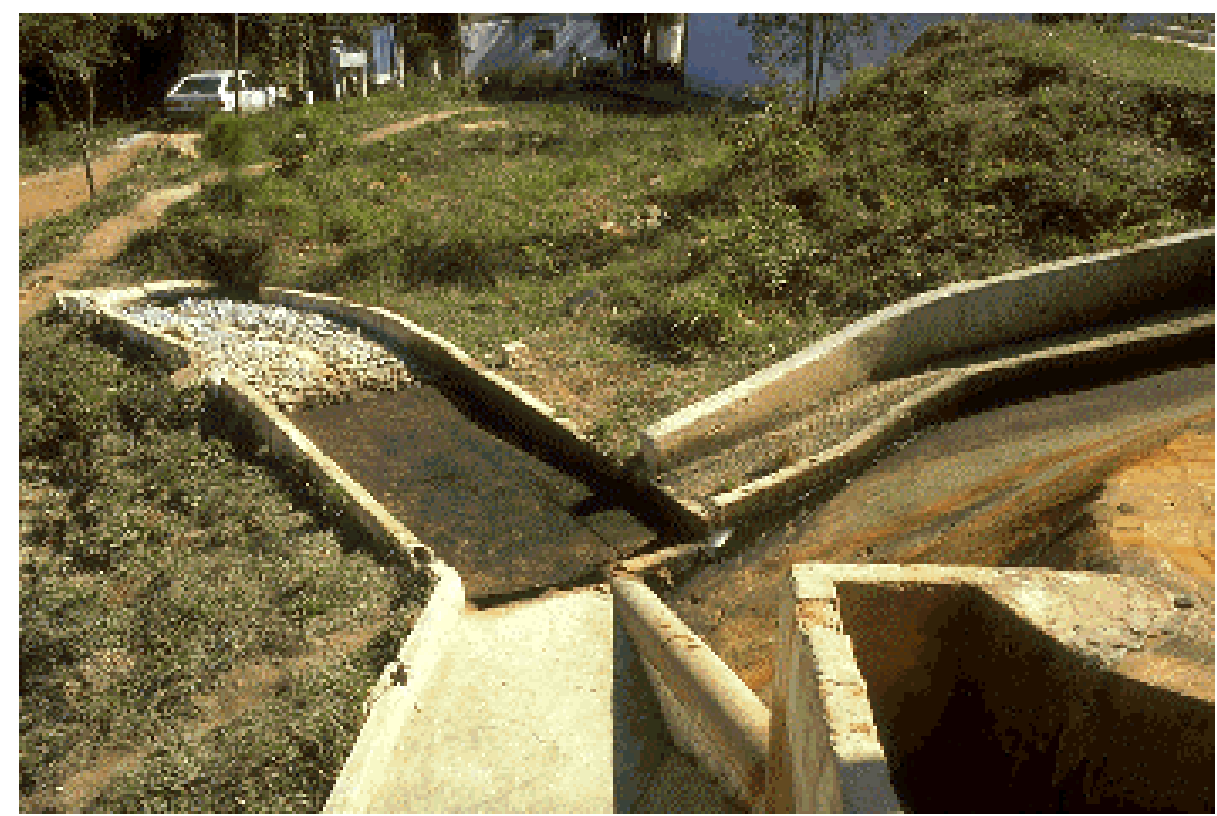




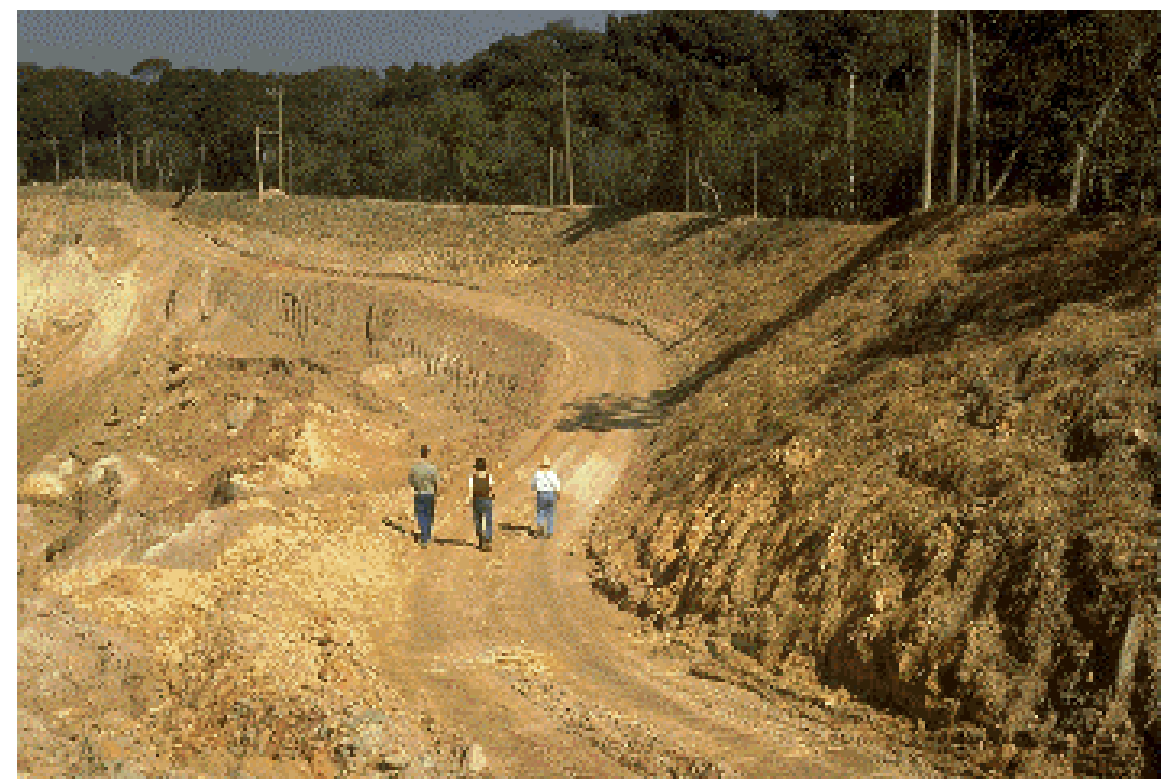

FOTO 50 - Revegetação implantada com herbáceas (gramíneas) em talude de via de circulação interna.

Mineração de areia Viterbo Machado Luz,

São Paulo ( AR-07 ).

FOTO 51 - Revegetação em execução com placas de herbáceas (gramíneas) em talude de via de circulação interna. Pedreira Itapiserra, Itapecerica da Serra ( BT-24 ).
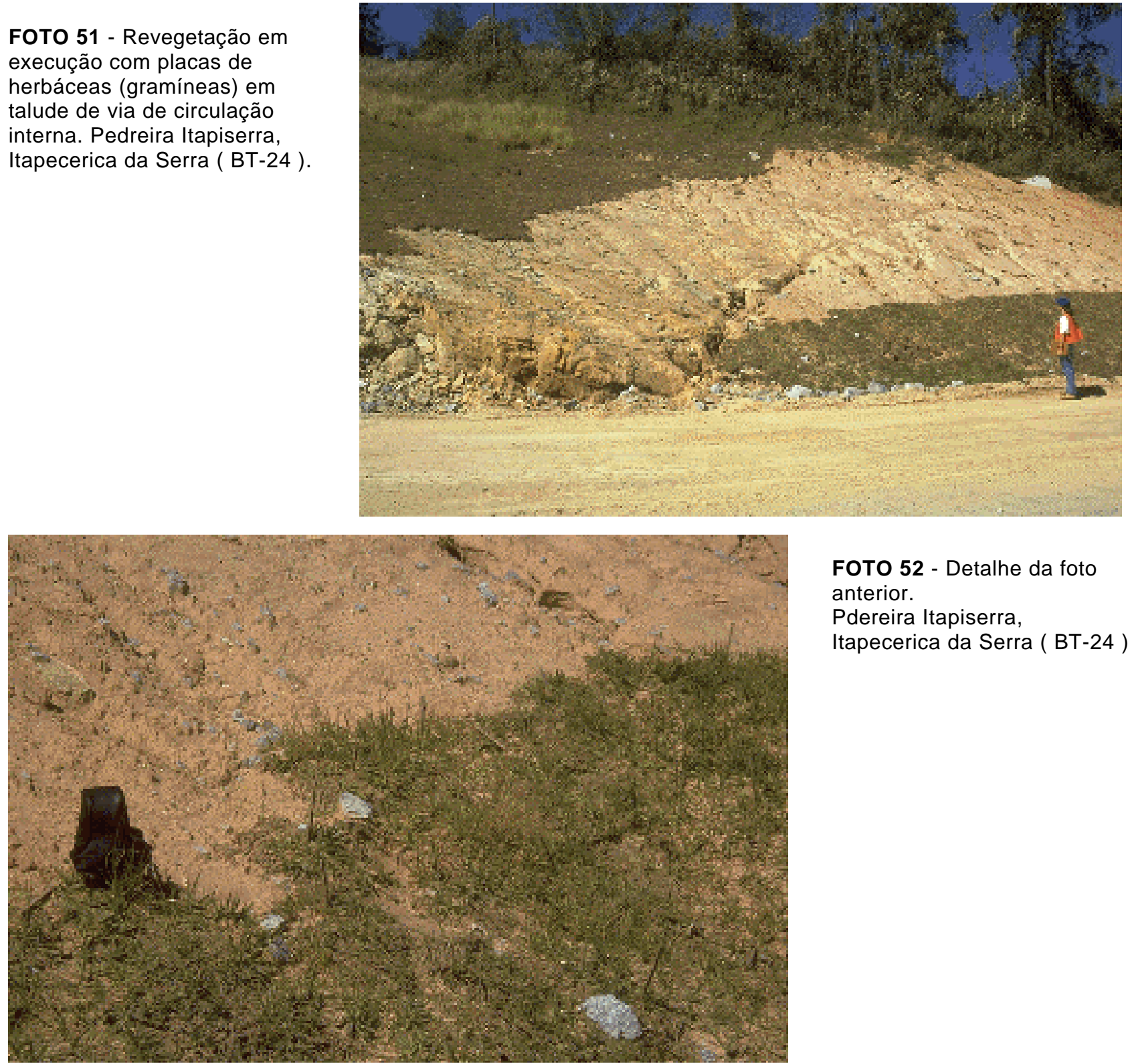

FOTO 52 - Detalhe da foto anterior.

Pdereira Itapiserra,

Itapecerica da Serra ( BT-24 ). 


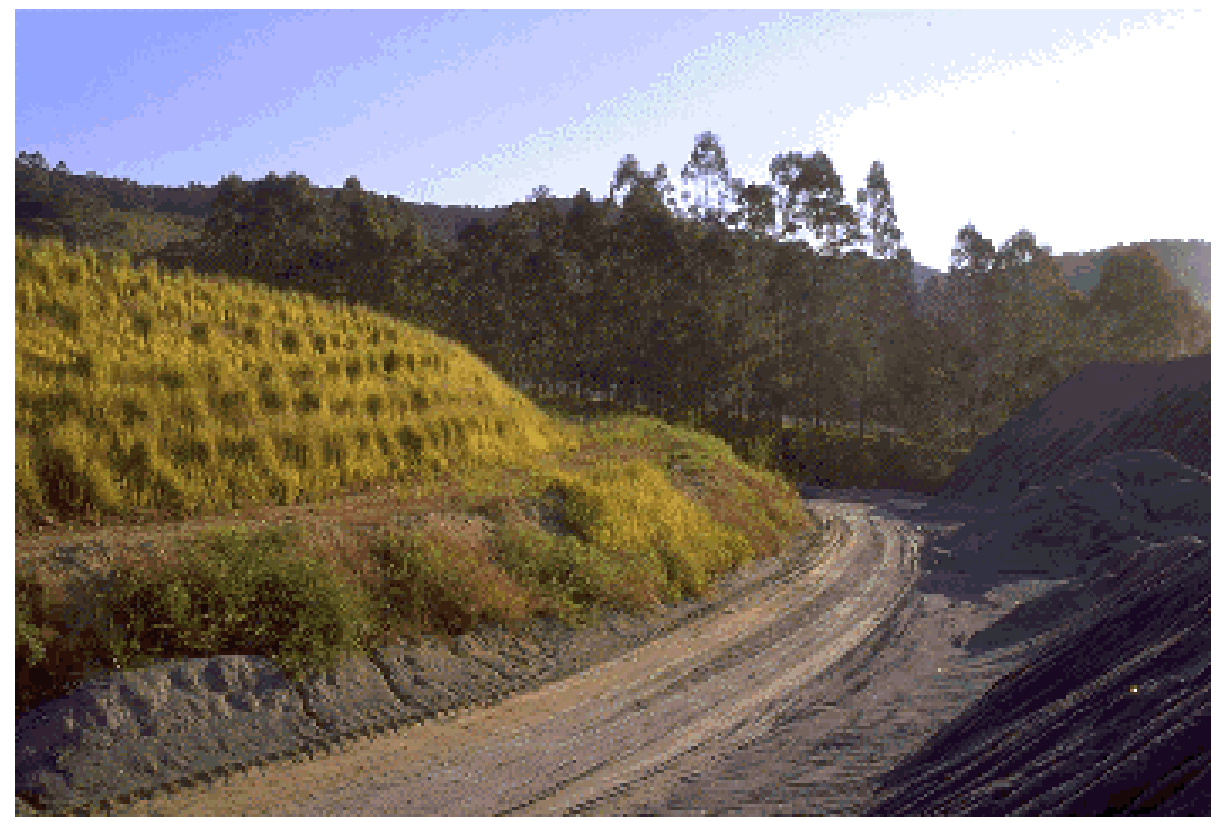

FOTO 53 - Revegetação implantada com uso de herbáceas (gramíneas) em talude de via de circulação interna.

Pedreira Mariutti,

Itapecerica da Serra ( BT-12).

FOTO 54 - Revegetação com uso de espécies arbóreas nativas, às margens de via de circulação interna.

Mineração de areia Ponte Alta, São Paulo ( AR-26 ).

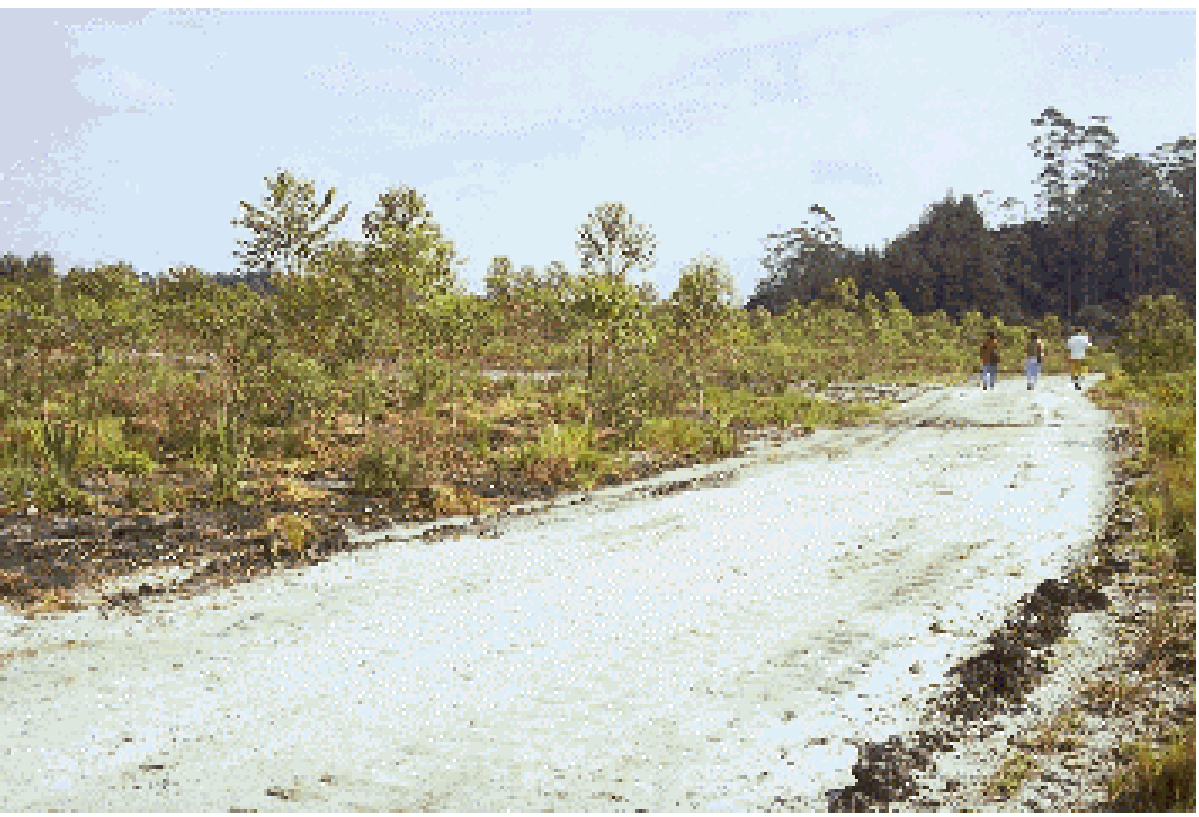




\subsubsection{Remoção de blocos rochosos instáveis em áreas lavradas}

Esta medida compreende a remoção dos blocos rochosos que se encontram em situação instável, tanto os que são gerados em detonações nos taludes finais de pedreiras e que, por isso, apresentam-se com formatos irregulares, quanto os matacões de frentes de lavra de minerações de areia expostos pelo desmonte hidráulico na zona de transição entre o solo e o embasamento rochoso. Tem a finalidade de evitar a queda desses blocos ou matacões e eliminar os riscos a eles associados.

Esta medida é geralmente executada com o uso de ferramentas manuais, como alavancas de ferro forjado com cerca de $15 \mathrm{~m}$ de comprimento, exigindo procedimentos extremamente cautelosos. Aplicável em minerações de brita, é realizada nos períodos em que a produção se encontra temporariamente paralisada, preferencialmente em fins de semana ou feriados, requerendo a participação dos mesmos profissionais envolvidos no cotidiano das atividades de lavra.

Nas minas em que esta medida tem sido empregada, particularmente as pedreiras, 0 desempenho pode ser considerado satisfatório, podendo ser aferido pela simples contagem do número de blocos instáveis que são retirados em relação aos que permanecem na frente de lavra.

\subsubsection{Abatimento e revegetação de taludes marginais em lagos remanescentes}

Esta medida consiste na execução de cortes suavizados nos taludes marginais de lagos remanescentes de cavas secas ou inundadas, seguido de revegetação, sobretudo em minerações de areia ou argila situadas em planícies aluviais (FOTOS 55 e 56). Tem a finalidade de estabilizar a porção emersa de taludes marginais, atribuindo-Ihes melhores condições de resistir ao embate de ondas geradas pelo vento e atenuando o impacto visual produzido àdistância.

É realizada por meio de máquinas como retroescavadeiras, tendo seu acabamento final feito com o emprego de ferramentas manuais. A inclinação final dos taludes é variável, situando-se em torno de $1 \mathrm{~V}: 1,5 \mathrm{H}$ nos setores entre o curso d'água e a cava da mineração. $\mathrm{A}$ revegetação é feita com plantio manual de gramíneas.

O desempenho desta medida pode ser considerado bastante satisfatório, particularmente nos casos de mineração de areia e argila aluvionar em que as condições de umidade dos terrenos favorecem a instalação e o rápido desenvolvimento da revegetação marginal. 


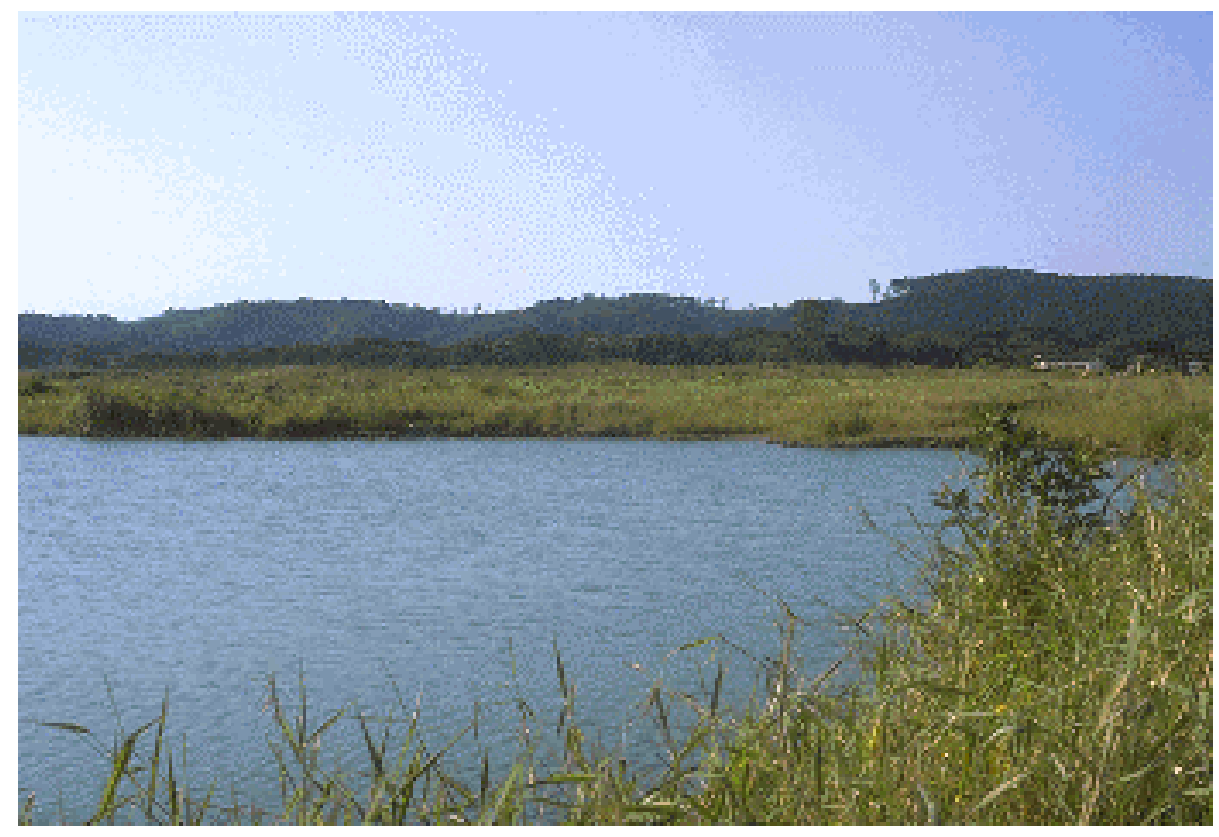

FOTO 55 - Abatimento ou suavização de talude marginal emerso, em lago remanescente de antiga cava em planície aluvionar.

Mineração de areia Cêmica, Biritiba-Mirim ( AR-02 ).

FOTO 56 - Mesmo caso da foto anterior, ressaltando-se, ao fundo, as instalações de beneficiamento em operação. Mineração de areia Cêmica, Biritiba-Mirim ( AR-02 ).

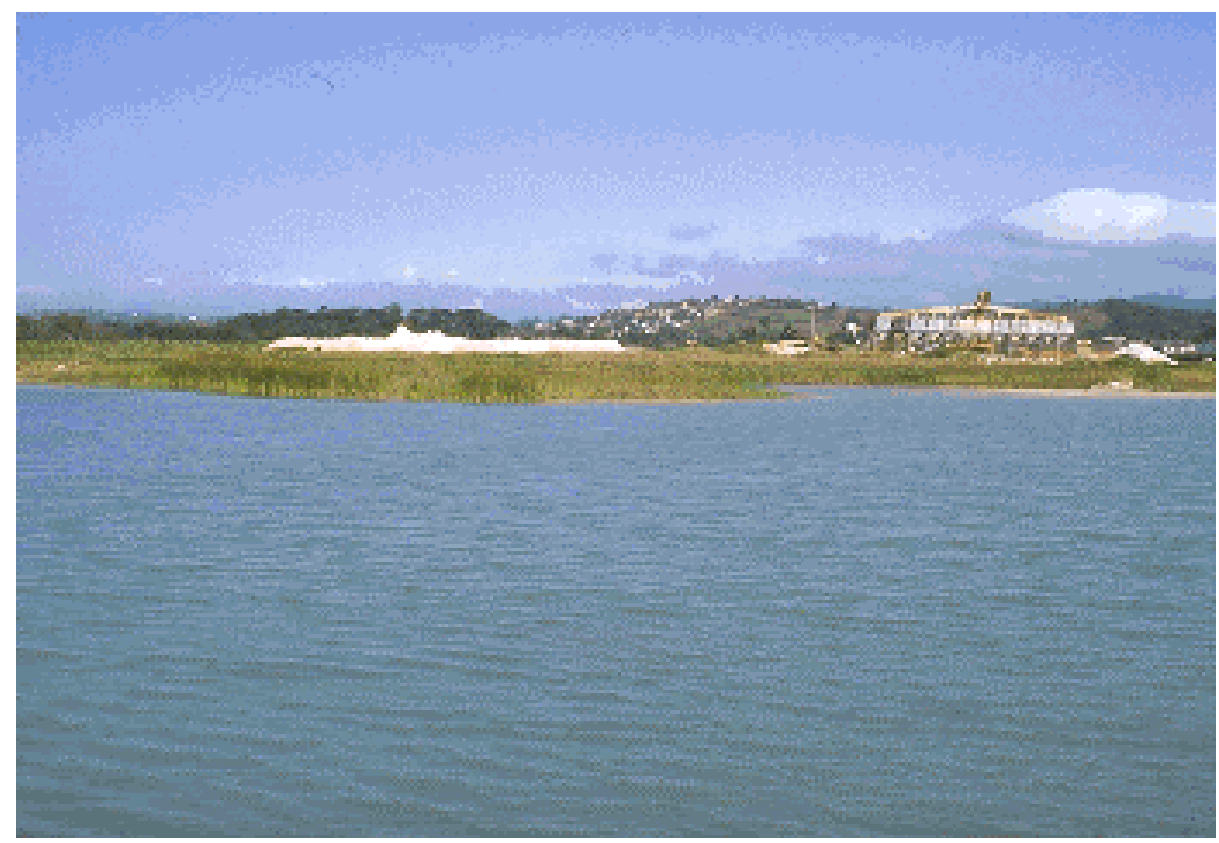




\subsubsection{Proteção e manejo da vegetação remanescente}

Esta medida compreende as ações voltadas àproteção e conservação de áreas de mata situadas no contexto ocupado pela mineração. Estimuladas pela necessidade de atender exigências legais comumente requeridas pelos órgãos ambientais, essas ações visam também compensar o impacto visual causado pelas áreas degradadas, tanto sob o ponto de vista externo quanto interno.

É executada por meio da identificação, definição e proteção das porções de matas remanescentes a serem preservadas, caracterizando-se pela aplicação de um manejo apenas incipiente e descontínuo (FOTO 57).

O desempenho desta medida traduz uma situação de transição, visto que sua eficácia tende a ser melhorada com a introdução de técnicas profissionais de manejo florestal.

\subsubsection{Indução e manejo da revegetação espontânea}

Esta medida consiste na submissão e controle de áreas degradadas a processos espontâneos ou naturais de fixação e desenvolvimento de vegetação arbórea, arbustiva ou herbácea. Tem a finalidade de revegetar áreas abandonadas no empreendimento.

É geralmente aplicada em antigas frentes de lavra e depósitos de bota-fora, sendo executada a partir da identificação, definição e proteção das áreas degradadas em que se pretende favorecer a recuperação ou regeneração espontânea do ambiente. $O$ desenvolvimento de espécies vegetais instaladas espontaneamente ocorre com o aporte natural de sementes provenientes de matas existentes nas proximidades, trazidas principalmente pela ação do vento e dos pássaros (FOTO 58).

Nas áreas expostas há alguns anos à recuperação espontânea, a revegetação tende a ser melhor sucedida do que nas de áreas plantadas, em que pesem eventuais dificuldades ocorridas no período inicial. O principal problema de desempenho está na preferência demonstrada nos empreendimentos por espécies árboreas, em detrimento das herbáceas, sobretudo as forrageiras. Isto tende a dificultar a recuperação e, na prática, estabelece um contrasenso, visto que as áreas recobertas por forrageiras tendem a conter rapidamente os processos de degradação instalados. Há casos em que, com a intenção de favorecer o desenvolvimento de algumas árvores, executam-se queimadas na vegetação rasteira próxima, o que afeta diretamente as gramíneas e retarda o processo de recuperação. Assim, esta medida pode ser muito melhorada por meio da aplicação de técnicas adequadas de manejo florestal. 


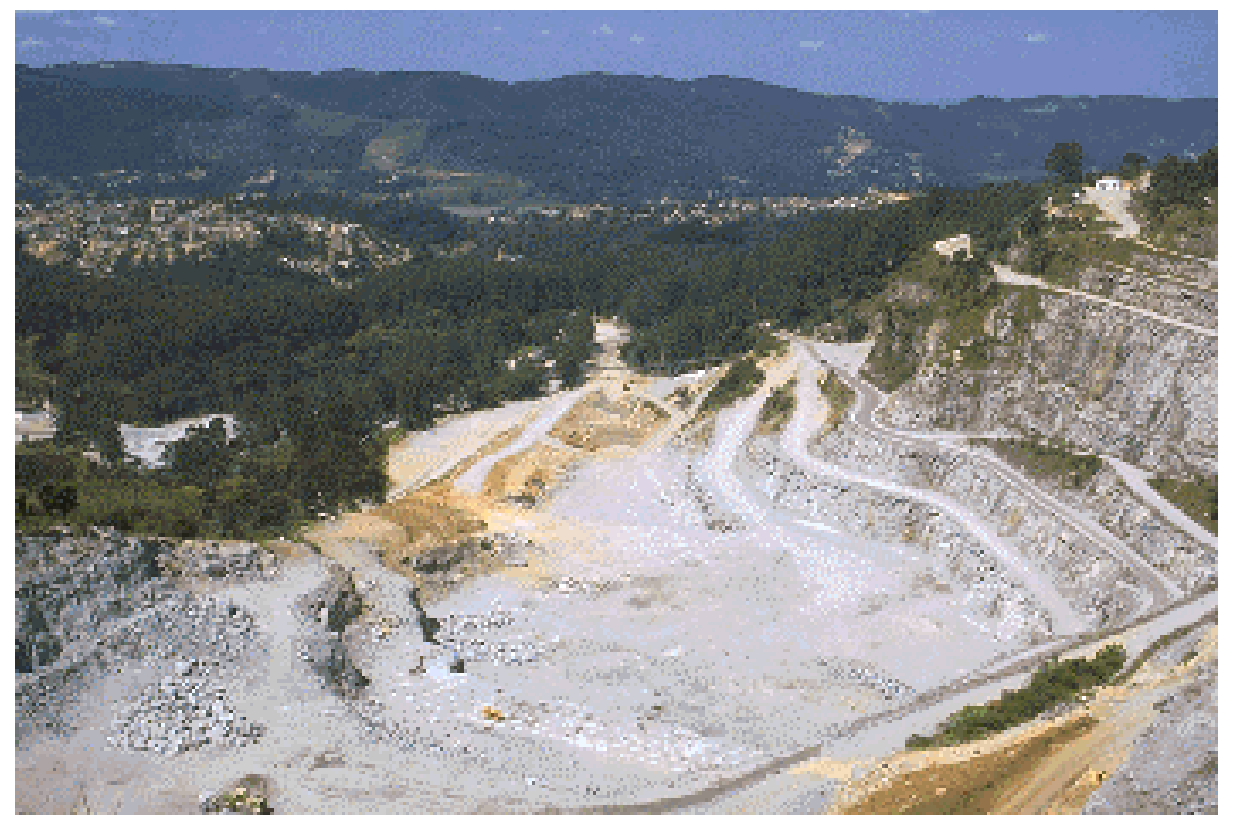

FOTO 57 - Panorama da

circunvizinhança da frente de lavra de rocha para produção de brita, cuja vegetação remanescente é manejada com vistas à sua conservação.

Pedreira Mariutti,

Itapecerica da Serra ( BT-12).

FOTO 58 - Área de antiga ocupação por atividades de mineração, atualmente em processo de recuperação espontânea.

Pedreira Alvenaria,

Mairiporã ( BT-13 ).

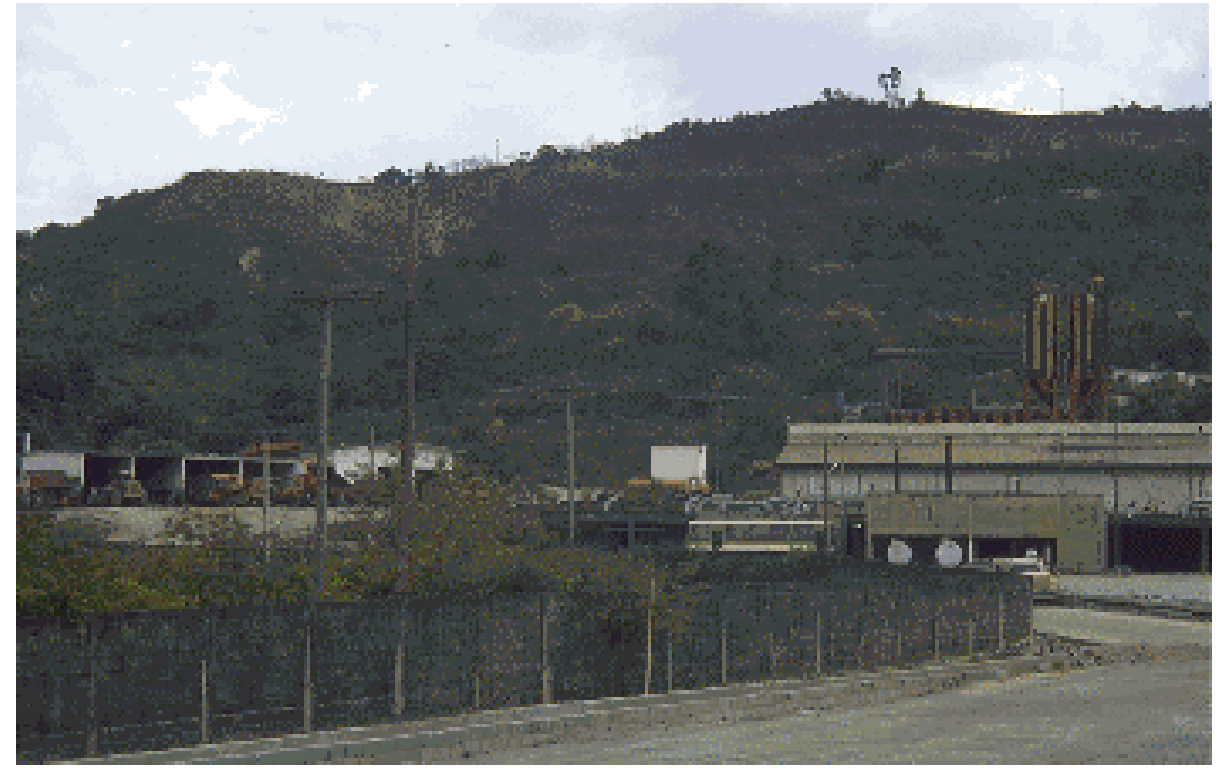




\subsubsection{Medidas experimentais}

As medidas experimentais compreendem procedimentos técnicos cuja eficácia ainda não pode ser plenamente verificada na área da mineração, independentemente do grau de difusão existente e da quantidade de minas ativas que as praticam.

\subsubsection{Revegetação em bermas e taludes rochosos}

Esta medida compreende o plantio de espécies vegetais nas bermas de bancadas de pedreiras. Tem a finalidade principal de atenuar o impacto visual ocasionado pela exposição das bancadas finais e, localmente, contribuir para a estabilização dos taludes rochosos.

É executada pelo plantio manual de mudas de espécies arbóreas na superfície das bermas, próximo àcrista dos taludes, além de herbáceas forrageiras e trepadeiras na base dos taludes. Envolve a colocação de solo na superfície da berma, inicialmente com uma camada de solo de alteração (solo saprolítico ou horizonte $C$ ) de cerca de $30 \mathrm{~cm}$ de espessura e, sobreposta, outra de solo superficial argiloso (horizonte B) com $30 \mathrm{a} 40 \mathrm{~cm}$, seguido do plantio. As mudas de herbáceas, como hera ou tumbeja, são plantadas diretamente no solo colocado. Para as arbóreas, adiciona-se uma camada de solo preparado nas instalações do viveiro de mudas, resultante da mistura de solo orgânico (solo superficial ou horizonte pedológico A), adubo orgânico (adubo de curral) e fertilizante inorgânico fosfatado. Não há sistema de drenagem (FOTOS 59 a 61).

O desempenho da revegetação ainda não pode ser aferido, visto que as mudas plantadas se encontram em fase inicial de desenvolvimento, monitorando-se as espécies que se adaptam melhor. Entretanto, a presença de exemplares de espécies arbóreas com até $4 \mathrm{~m}$ de altura (por exemplo, paineira) e arbustivas, ambas fixadas naturalmente na linha entre bermas e taludes, sugere ser este (e não junto à crista) o local mais favorável para o plantio. Não obstante, com o tempo, pode-se esperar pelo sucesso da revegetação, particularmente das trepadeiras e no que se refere à atenuação do impacto visual. Os aspectos que certamente deverão merecer especial atenção, prendem-se às incertezas sobre o papel das espécies arbóreas na estabilidade das bancadas rochosas finais.

Outra variação desta medida, em bancadas de pedreiras, está no remodelamento do perfil das bancadas finais, com a colocação de uma base de aterro (solo de alteração ou horizonte pedológico $\mathrm{C}$ ), seguida de uma camada de solo superficial (horizonte pedológico $\mathrm{A}$ e B) e plantio de herbáceas forrageiras em placas no topo e semeadura manual no restante do talude. Esta medida está vinculada às mudanças no plano de lavra e, dependendo das condições de drenagem no aterro, tende a apresentar bons resultados (FOTO 62). 


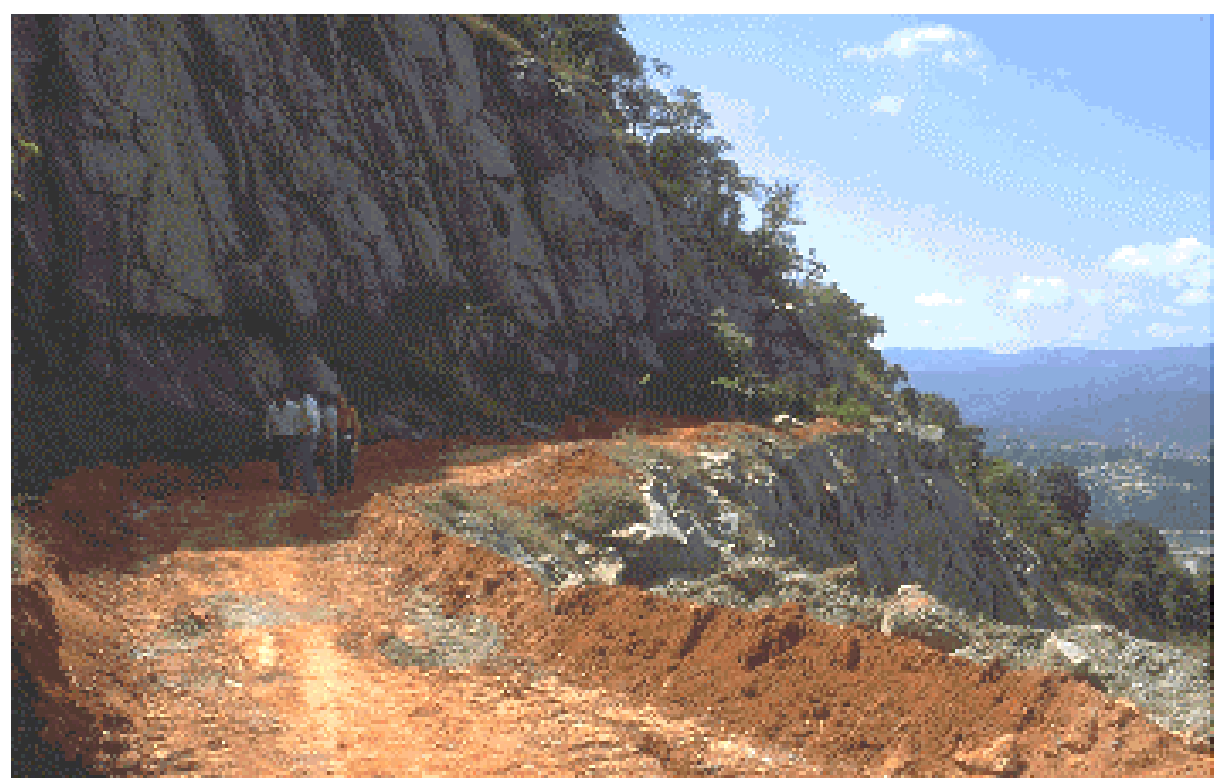

FOTO 59 - Solo preparado para o plantio de espécies arbóreas em bermas rochosas.

Pedreira Cantareira, Mairiporã ( BT-14 ).

FOTO 60 - Mudas de espécies arbóreas nativas plantadas em bermas rochosas de pedreiras, dispostas junto àcrista do talude inferior.

Pedreira Cantareira, Mairiporã ( BT-14 ).

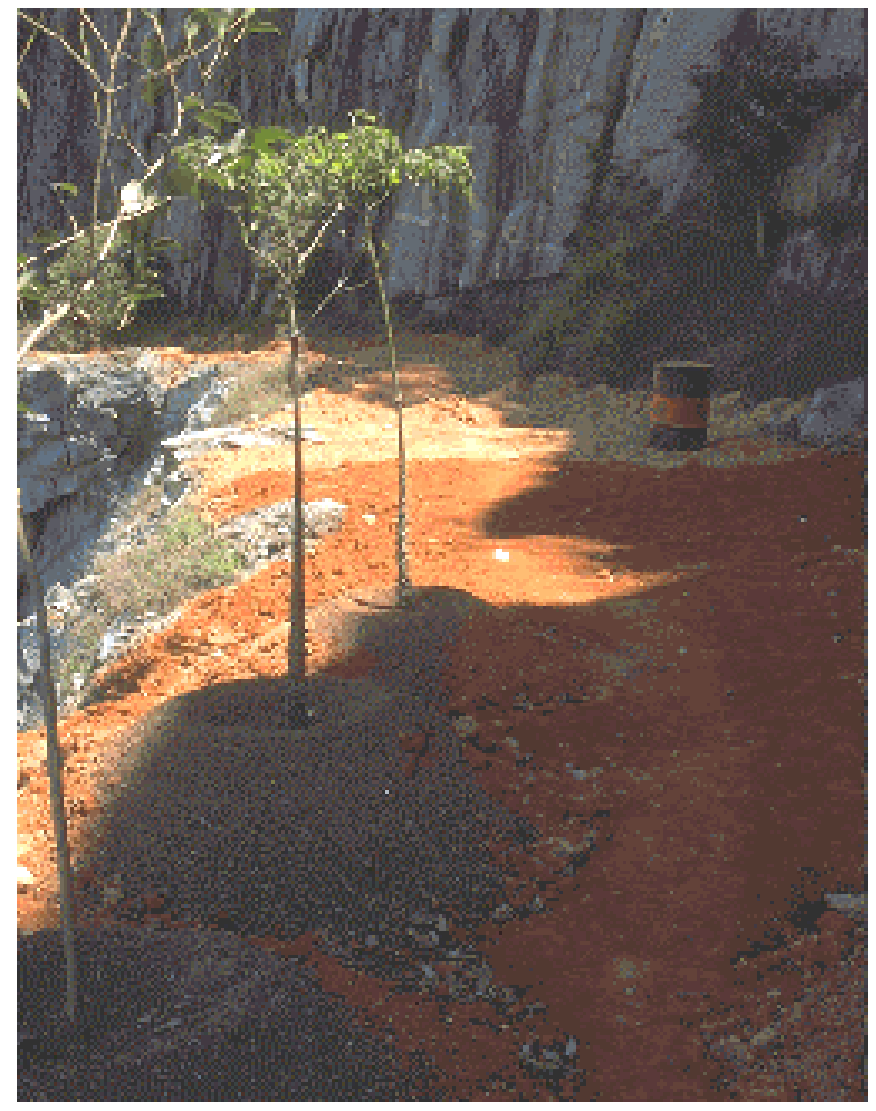




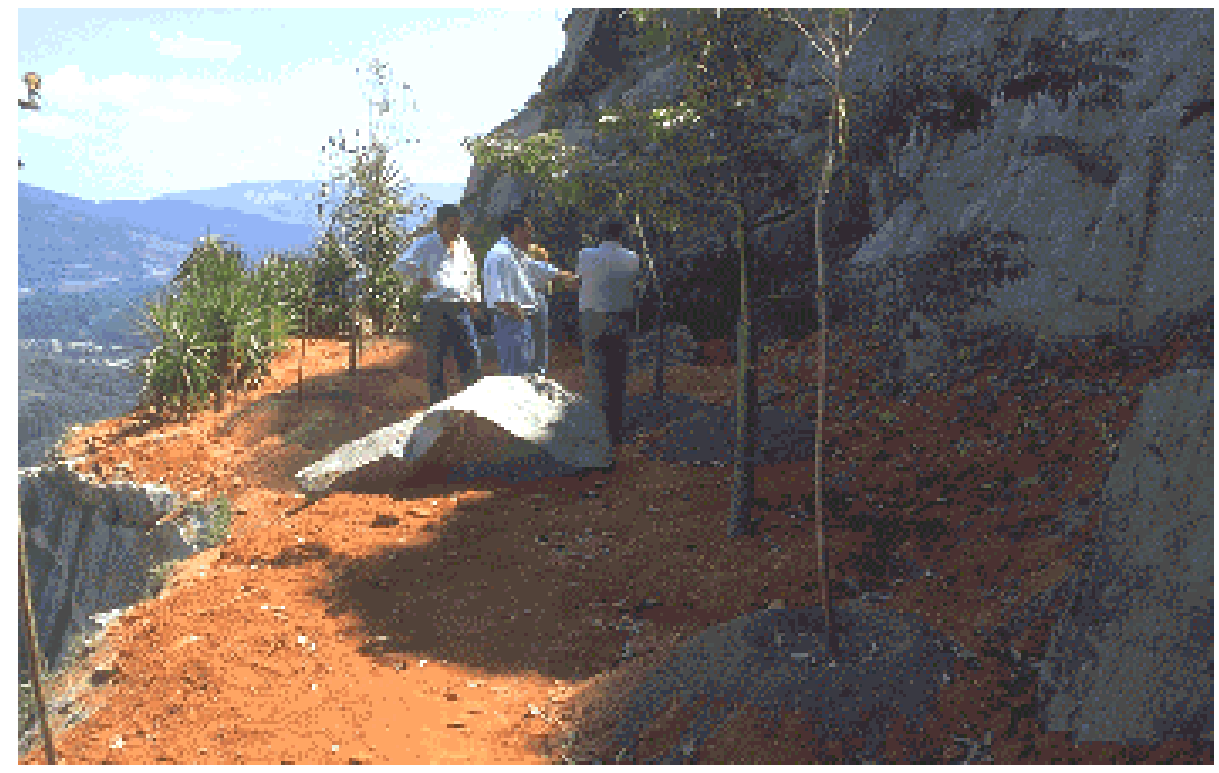

FOTO 61 - Mudas de espécies arbóreas nativas plantadas em bermas rochosas de pedreiras, dispostas junto àbase do talude superior.

Pedreira Cantareira,

Mairiporã ( BT-14 ).

FOTO 62 - Remodelamento setorizado do perfil de bancadas finais, com colocação de aterro (solo de alteração), cobertura de solo superficial e plantio de gramíneas em placas. Pedreira Cantareira Mairiporã ( BT-14 ).

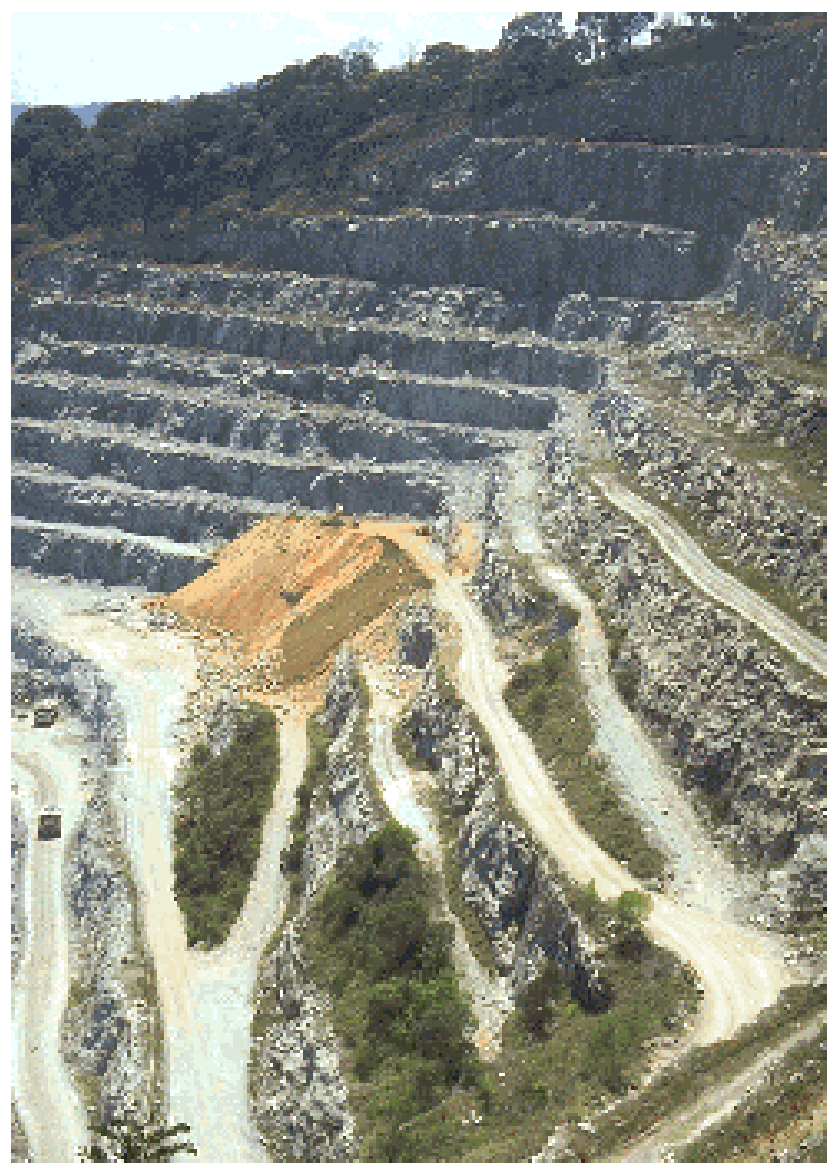




\subsubsection{Revegetação em solos de alteração de rocha}

Outra medida em caráter experimental é o plantio planejado e exclusivo de espécies arbóreas nativas diretamente sobre terrenos com solos de alteração (solo saprolítico ou horizonte pedológico $\mathrm{C}$ ) expostos. Ocorre especialmente em áreas remanescentes de antigas frentes de lavra de minerações de areia em morros ou morrotes constituídos de rochas de idade pré-cambriana e de composição granítica. Tem a finalidade de revegetar áreas abandonadas no empreendimento e atenuar o impacto visual.

A medida se fundamenta no plantio aleatório ou espacialmente pouco adensado de mudas, manejo individual e adubação constante, às vezes com material orgânico proveniente de compostagem de lixo urbano. As mudas de nativas utilizadas correspondem a espécies que ocorrem em áreas de mata natural da região.

Os resultados até então obtidos, embora ainda incertos, sugerem boas perspectivas de desempenho e eficácia desta medida, pois os experimentos realizados indicam a sobrevivência da maior parte das mudas plantadas. As incertezas estão relacionadas à velocidade de recuperação em face das condições do solo saprolítico, bem como àpossível contaminação do solo e das mudas por metais presentes no composto de lixo urbano utilizado.

\subsubsection{Síntese do desempenho das medidas praticadas}

A TABELA 5.5 sintetiza o desempenho geral das medidas de recuperação identificadas.

TABELA 5.5- Síntese do desempenho das medidas de recuperação, segundo a finalidade principal.

\begin{tabular}{|c|c|c|}
\hline Medidas de recuperação & Finalidade principal & Desempenho \\
\hline Instalação de barreiras vegetais & Atenuação do impacto visual & $\mathrm{RaI}$ \\
\hline Arborização dispersa na área da mineração & Atenuação do impacto visual & 1 \\
\hline Remodelamento topográfico & Atenuação do impacto visual & $\mathrm{R} \mathrm{a} \mathrm{I}$ \\
\hline Retaludamento e revegetação de áreas lavradas & Estabilização geotécnica & $\mathrm{R}$ \\
\hline Revegetação de taludes de barragens de rejeito & Atenuação do impacto visual & $\mathrm{R}$ a I \\
\hline Remoção, estocagem e utilização da camada orgânica do solo superficial & Revegetação & $\mathrm{R}$ a S \\
\hline Remoção, estocagem e utilização da camada argilosa do solo superficial & Revegetação & Ra S \\
\hline Remoção dirigida de estéreis e preenchimento de cavas & Redução de volumes de estéril & $\mathrm{S}$ \\
\hline Instalação de sistemas de drenagem em barragens de rejeito & Estabilização geotécnica & $\mathrm{R}$ a S \\
\hline Reforço e revegetação em barragens de rejeito & Estabilização geotécnica & $\mathrm{R}$ \\
\hline Instalação de extravasores em barragens de rejeito & Estabilização geotécnica & $\mathrm{I}$ \\
\hline Transposição de rejeitos de bacias de decantação para áreas lavradas & Redução de volumes de rejeito & $\mathrm{S}$ \\
\hline Instalação de sistemas de drenagem e retenção de sedimentos & Estabilização geotécnica & $\mathrm{R}$ \\
\hline Construção e estabilização de bota-foras & Estabilização geotécnica & 1 \\
\hline Retenção e coleta de óleos e graxas & Estabilização química & RaS \\
\hline Revegetação de taludes em acessos e vias internas & Atenuação do impacto visual & $\mathrm{R}$ a S \\
\hline Remoção de blocos rochosos instáveis em áreas lavradas & Estabilização geotécnica & RaS \\
\hline Abatimento e revegetação de taludes marginais em lagos remanescentes & Atenuação do impacto visual & RaS \\
\hline Proteção e manejo da vegetação remanescente & Atenuação do impacto visual & $\mathrm{R}$ a I \\
\hline Indução e manejo da revegetação espontânea & Atenuação do impacto visual & $\mathrm{RaI}$ \\
\hline Revegetação em bermas e taludes rochosos & Atenuação do impacto visual & tende a S \\
\hline Revegetação de solos de alteração de rochas & Atenuação do impacto visual & tende a S \\
\hline
\end{tabular}




\section{CAPÍTULO 6}

\section{REABILITAÇÃO E USOS PÓS-MINERAÇÃO NA RMSP}

Este Capítulo apresenta e discute os resultados da avaliação sobre a reabilitação de áreas degradadas por atividades de mineração na RMSP, baseando-se no levantamento da situação de minas desativadas e de antigas áreas de mineração atualmente ocupadas por outros usos.

\subsection{Degradação em minas desativadas}

As minas desativadas compreendem áreas em que a atividade se encontra encerrada há muitos anos, não abrigam um uso do solo definido e tampouco apresentam evidências de que a extração possa ser retomada. Às vezes são utilizadas por formas temporárias ou provisórias de uso, como pátios de obras ou campos de futebol. Algumas dessas áreas, particularmente aquelas pertencentes aos antigos proprietários das empresas de mineração, encontram-se sob permanente vigilância e protegidas contra invasões ou descargas clandestinas de resíduos por cercas ou muros de concreto (TABELA 6.1 e FIGURA 6.1).

TABELA 6.1- Relação das minas desativadas estudadas.

\begin{tabular}{l|l|l}
\hline Código & \multicolumn{1}{|c}{ Empreendimento } & \\
\hline AG-02 & Indústria Brasileira de Argilas Refratárias & Estr. Mogi das Cruzes-Casa Grande,km 73, Faz. Irohy- Biritiba Mirim \\
\hline AG-03 & Indústria Brasileira de Argilas Refratárias & Estr. das Varinhas, Parque das Varinhas- Mogi das Cruzes \\
\hline AR-17 & Porto de Areia Global & Estr. da Colina 1.700, Parelheiros- São Paulo \\
\hline AR-19 & Mineração Devechi \& Devechi & Parelheiros- São Paulo \\
\hline BT-03 & Pedreira Jaguaré & Av. Jaguaré esquina c/ Corifeu de A. Marques, Jaguaré- São Paulo. \\
\hline BT-09 & Pedreira Aidar & Estr. da Barrocada s/n, Vila Galvão- Guarulhos. \\
\hline BT-20 & Pedreira Mantiqueira & Rodovia Fernão Dias, Mairiporã \\
\hline BT-31 & Pedreira Firpavi & Rodovia Raposo Tavares km 17, Jardim do Lago- São Paulo. \\
\hline BT-16 & Antiga Pedreira Rabello & Rodovia Regis Bittencourt, km 294- Itapecerica da Serra. \\
\hline KI-03 & Empresa de Mineração Joseph Nigri & Estr. da Varginha s/n, Parelheiros- São Paulo \\
\hline KI-07 & Sociedade Caolinita de Mineração & Estr. de Santa Rita 13.000, Santa Rita- Embu-Guaçu \\
\hline Obs: 0s
\end{tabular}

Obs.: os códigos AG-argila, AR-areia, BT-brita e KI-caulim, representam os bens minerais explotados à época em que as minerações se encontravam em atividade. 
FIGURA 6.1 - Localização das minas desativadas estudadas na RMSP - Ver Pasta Desenhos 
Análise das características da degradação existente nas áreas de minas desativadas, dado o aspecto de que representam situações em que a atividade mineral foi encerrada há muitos anos, permite distinguir os seguintes tipos principais, segundo o bem mineral anteriormente lavrado:

a) áreas outrora destinadas ao aproveitamento de areia ou de caulim em contexto de solos de alteração (solo saprolítico ou horizonte pedológico C) provenientes de rochas cristalinas de composição granítica e idade pré-cambriana e em relevo de morros ou morrotes, em que ocorrem processos de degradação intensos e acelerados. Os impactos e alterações ambientais comumente verificados são: impacto visual causado pelos contrastes com as áreas de mata circunvizinhas; perda de solo e terrenos por erosão linear em sulcos e ravinas e por escorregamentos; perda de vegetação pela queda de árvores e arbustos, decorrentes sobretudo de escorregamentos remontantes; queda de blocos e matacões instáveis em antigas frentes de lavra, particularmente em meio à zona de transição entre os solos de alteração e o embasamento rochoso (rocha sã ou horizonte D); produção contínua de sedimentos, seguida de transporte por meio de drenagens locais e conseqüente turvamento e assoreamento dos corpos d'água situados a jusante; e modificação da dinâmica de circulação das águas superficiais e subterrâneas pela consolidação de bacias de decantação anteriormente instaladas em drenagens, gerando áreas setorialmente sujeitas a inundações e alagamentos (FOTOS 63 a 66);

b) áreas remanescentes de antigas pedreiras de produção de brita em contexto de rochas cristalinas e relevo de morros, geralmente situadas em meio à complexidade viária do ambiente urbano, em que se observa relativa estabilidade. Nestes locais, ressalta-se a presença de diversas lascas ou blocos rochosos instáveis nas bancadas ou paredes finais, além de alguns equipamentos e instalações abandonados (FOTOS 67 e 68); e

c) áreas de antigas extrações de areia ou de argila em sedimentos e planícies aluvionares, cujas cavas remanescentes, total ou parcialmente inundadas, encontram-se permanentemente sujeitas aos riscos de descargas clandestinas de resíduos. Em lagos de antigas extrações de argila, destaca-se o impacto visual causado pelas irregularidades deixadas pelas escavações e pela percepção de inutilização das áreas (FOTO 69). 


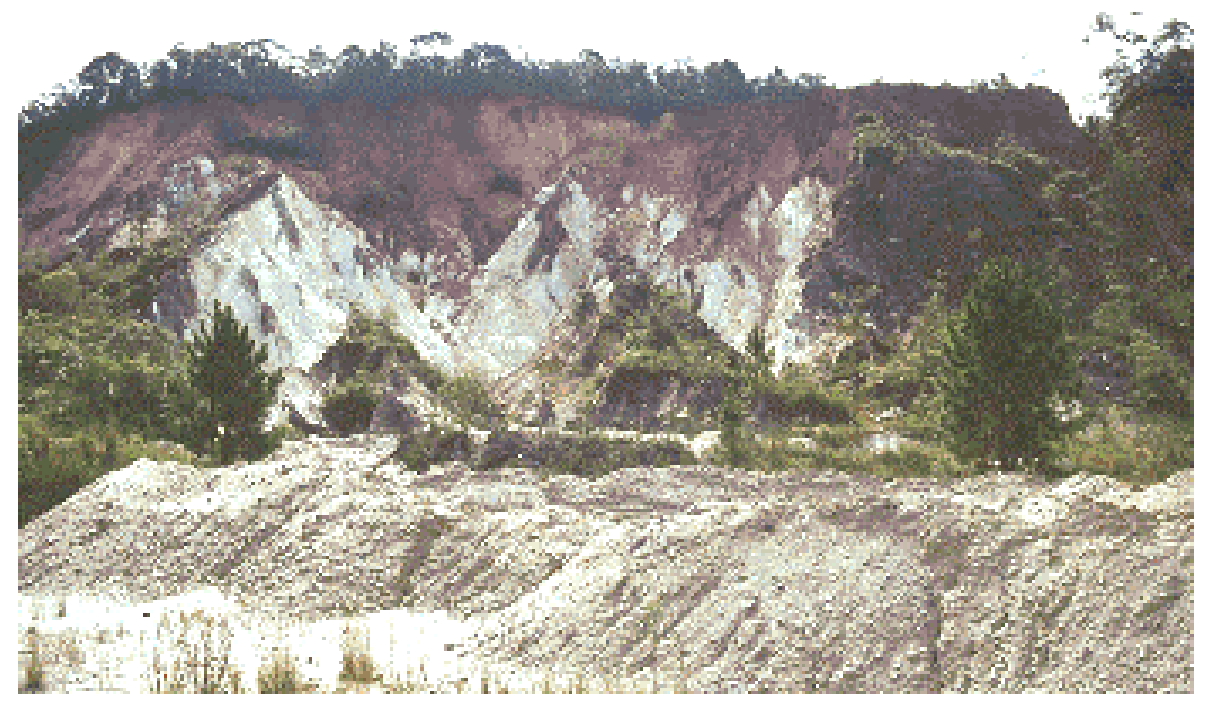

FOTO 63 - Desenvolvimento de processos de instabilização (erosão e escorregamentos) em antiga frente de lavra desativada e abandonada.

Mineração de caulim Caolinita, Embu-Guaçu ( KI-07 ).

FOTO 64 - Mesma área da foto anterior, destacando feições de escorregamentos.

Mineração de caulim Caolinita, Embu-Guaçu ( KI-07 ).

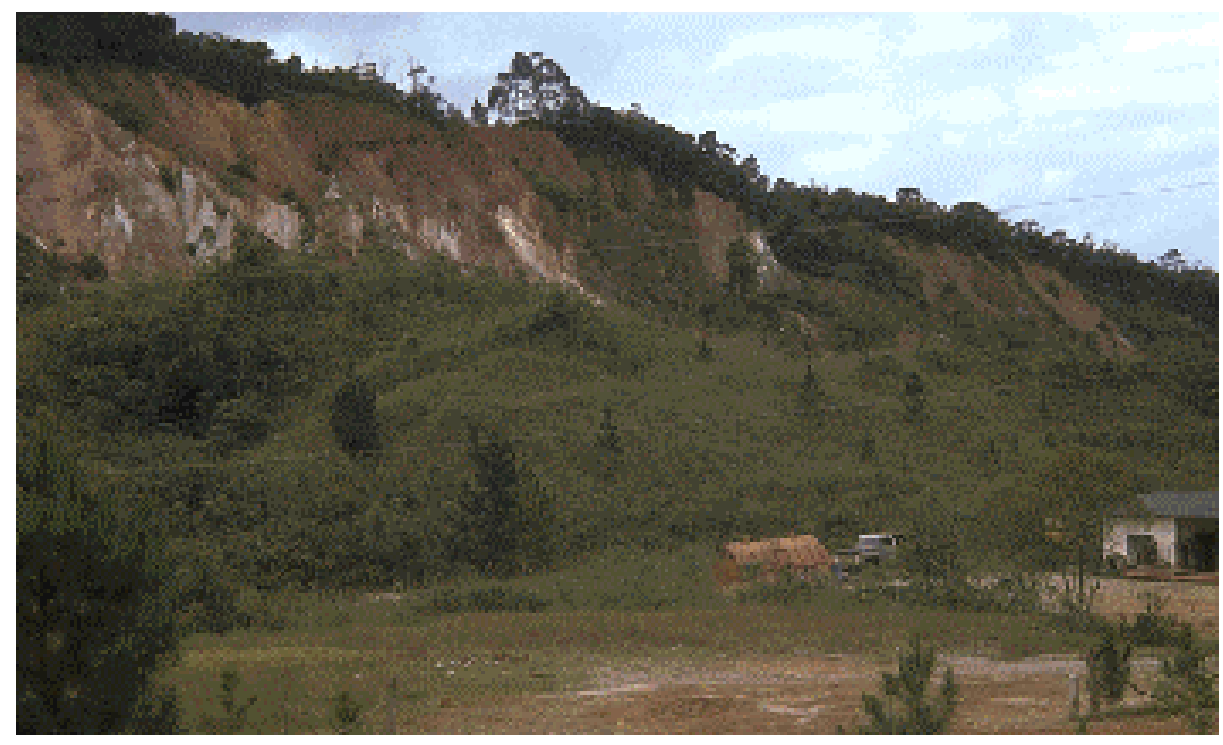




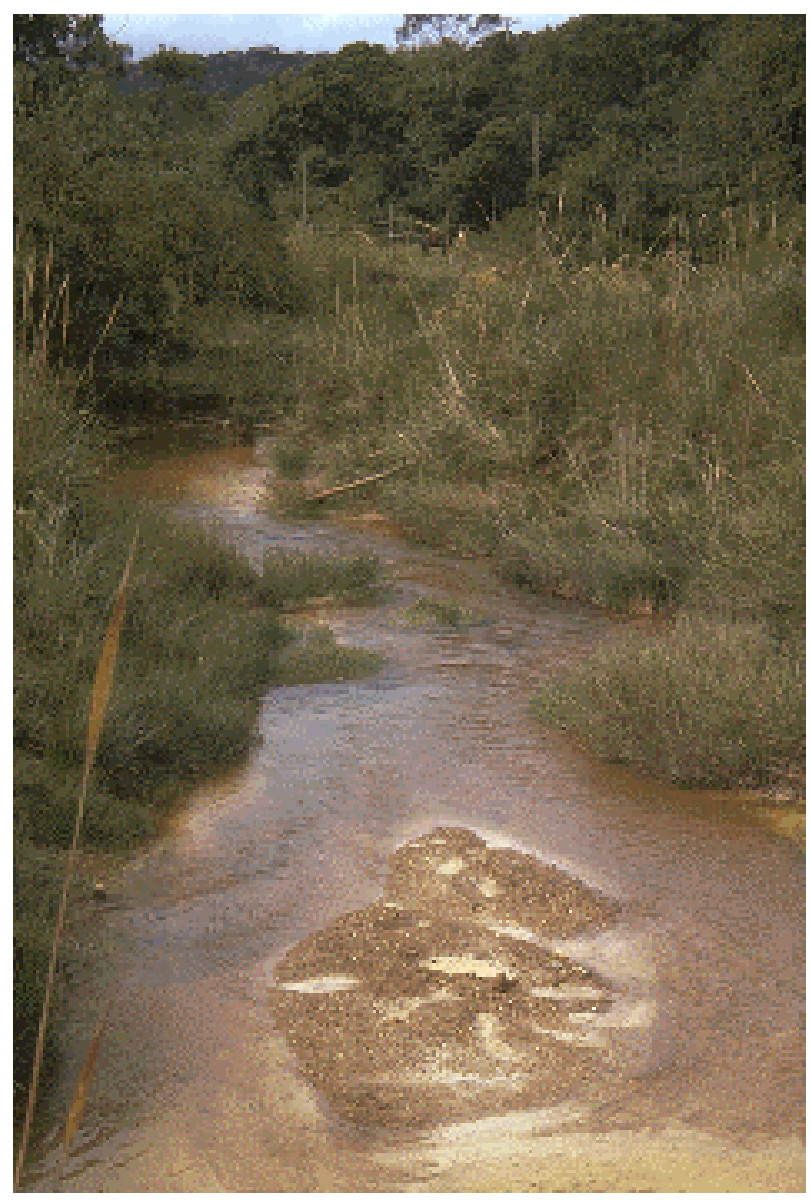

FOTO 65 - Mesma área das fotos anteriores, destacando o assoreamento em córrego situado a jusante da mina desativada. Mineração de caulim Caolinita,

Embu-Guaçu ( KI-07 ).

FOTO 66 - Área de antiga bacia de rejeitos de mineração de areia. Mineração Devechi \& Devechi,

São Paulo ( AR-19).

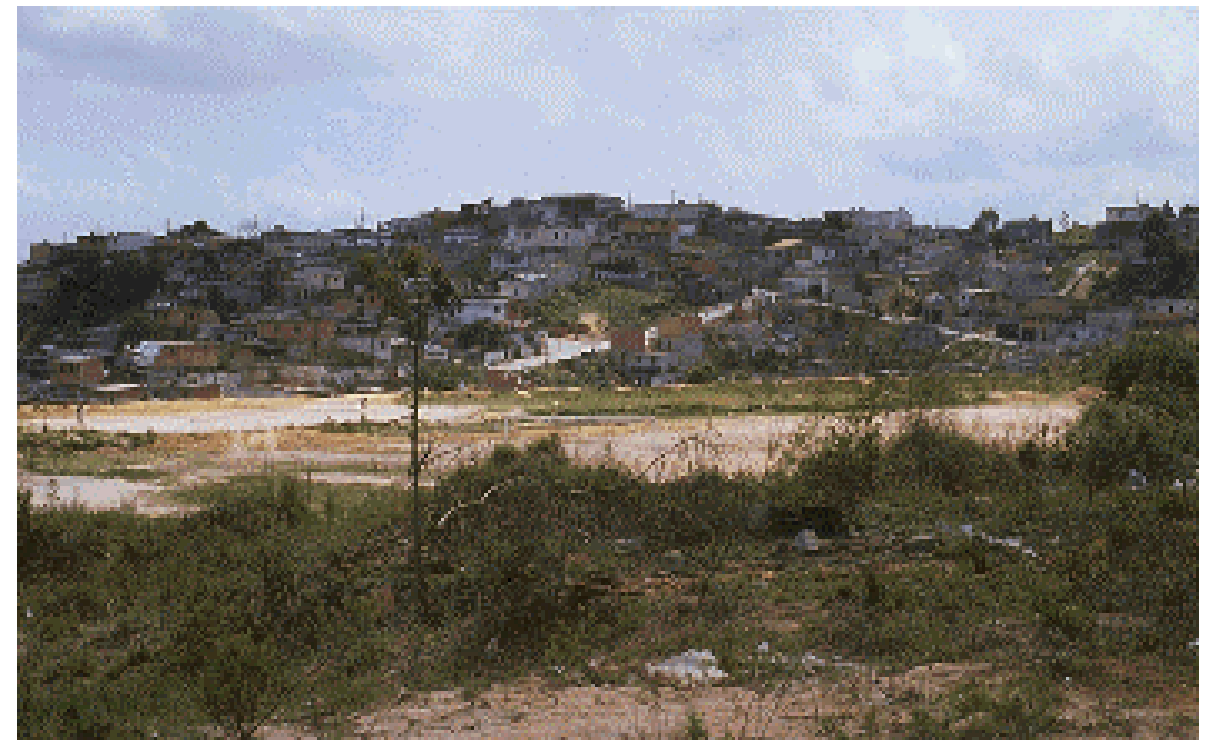




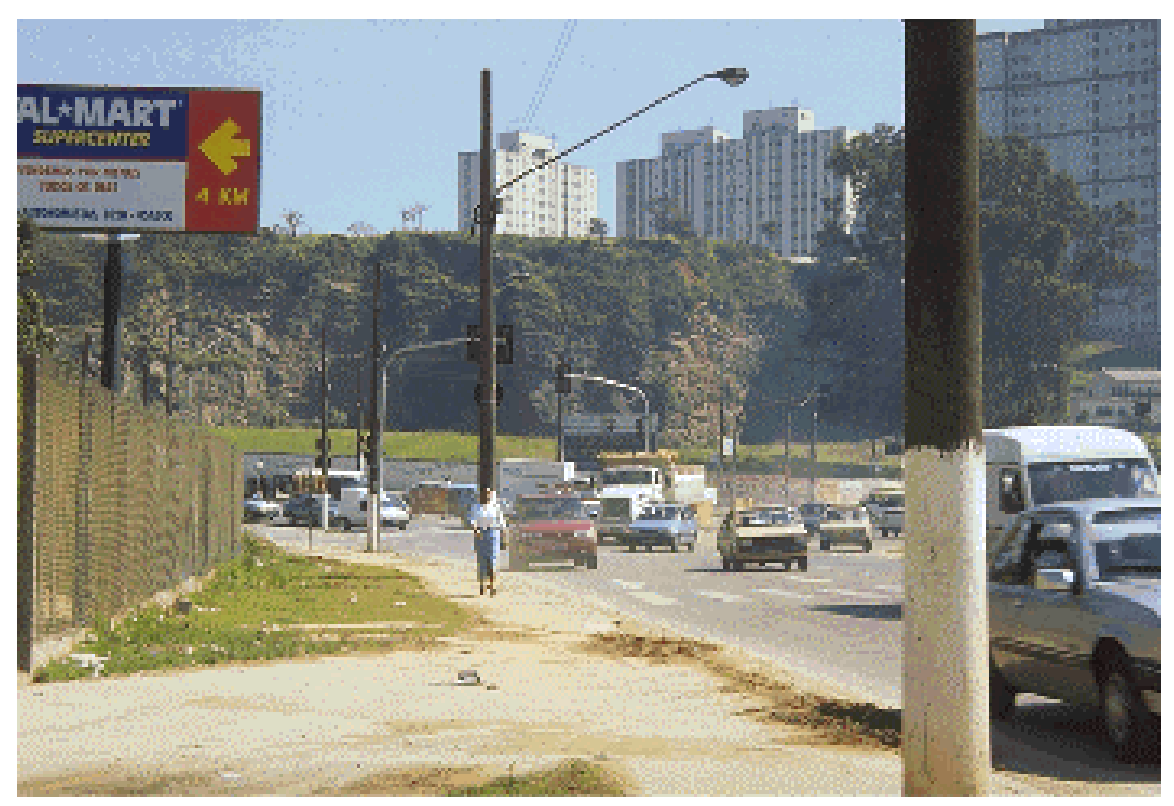

FOTO 67 - Ao fundo, pedreira desativada em meio urbano. Pedreira Jaguaré,

São Paulo ( BT-03 ).

FOTO 68 - Pedreira desativada próxima àrodovia Raposo Tavares.

Pedreira Firpavi,

São Paulo ( BT-31).
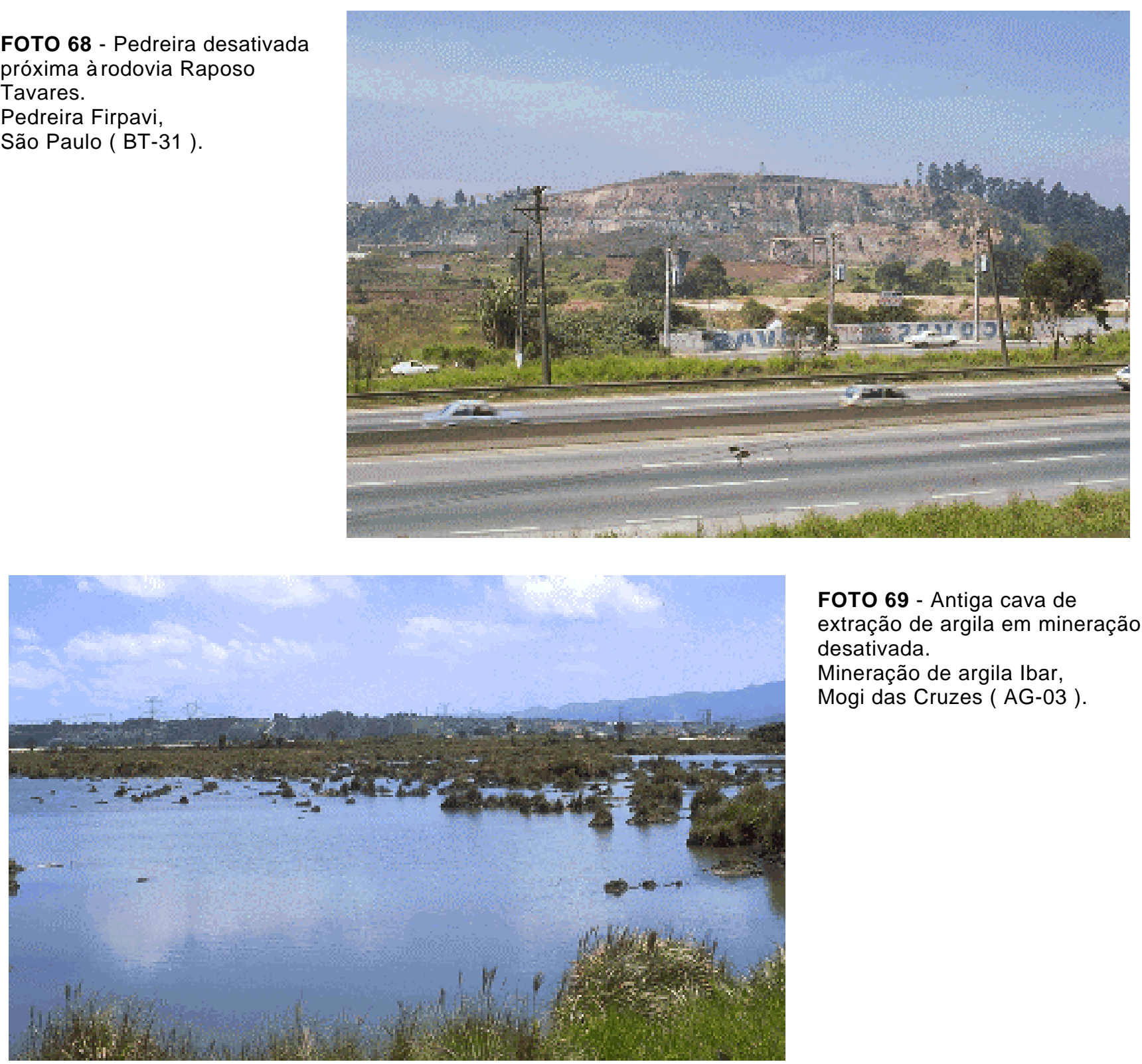

FOTO 69 - Antiga cava de extração de argila em mineração desativada.

Mineração de argila Ibar, Mogi das Cruzes ( AG-03). 


\subsection{Uso do solo em antigas áreas de mineração}

O levantamento e análise de 41 antigas áreas de mineração atualmente ocupadas por outros usos do solo, permite distinguir duas situações: áreas em que a ocupação ocorre de forma desordenada ( $24 \%$ dos casos levantados); e áreas em que se implementa algum projeto planejado de uso pós-mineração (76\% dos casos levantados).

Uma análise da distribuição territorial das minas antigas ao longo do tempo, propicia observar que a crescente demanda por materiais de construção atribuiu características peculiares ao processo de desenvolvimento das atividades de mineração na metrópole, especialmente em suas relações com o uso do solo. Entre outros aspectos, destaca-se a sucessão de aberturas e fechamentos de cavas de areia, cascalho e argila, desencadeada ao longo das planícies aluvionares dos rios Pinheiros e Tietê principalmente a partir da década de 50 , motivada pelo encerramento da lavra em leito de rio e pela contínua exaustão de volumes lavráveis nas planícies aluvionares, com a conseqüente necessidade de busca de novas jazidas para atender a crescente urbanização.

Outro aspecto notável está relacionado ao progressivo esgotamento do cascalho utilizado em concretos e à sua substituição por rocha britada, motivando a instalação de pedreiras nos arredores da cidade de São Paulo. Com a aceleração da expansão urbana rumo às áreas periféricas da metrópole e o adensamento da ocupação nas circunvizinhanças dos empreendimentos, desencadeiam-se sucessivas transferências e aberturas de novas minas em locais cada vez mais distantes da região central.

Evolução similar se verifica também em relação às minas de argila e de areia, entre outros bens minerais. No caso da areia, entretanto, além da busca por novas áreas disponíveis em planícies aluvionares, inicia-se, em meados da década de 50, a mudança do tipo de jazimento explotado. Motivada pela necessidade de manter a proximidade dos locais de consumo, a atividade mineral passa a aproveitar também solos provenientes da alteração de rochas cristalinas de composição granítica e idade pré-cambriana presentes em morros e morrotes, bem como os sedimentos terciários de natureza arenosa em relevo de colinas.

\subsubsection{Ocupação desordenada}

Estas áreas correspondem a minas que, a partir da desativação e abandono, têm sido progressivamente ocupadas de forma desordenada. O caráter de desordem é revelado por evidências de uma ocupação realizada sem um projeto de uso prévio, seja fundamentado em algum estudo de planejamento ou mesmo em práticas comuns de engenharia adequada. Além disso, retratam um modo de uso do solo cujas possibilidades de gerenciamento e 
sustentabilidade são extremamente incertas. A TABELA 6.2 ilustra características do uso do solo nas áreas estudadas (FIGURA 6.2).

TABELA 6.2- Relação das antigas áreas de mineração atualmente ocupadas de forma desordenada e estudadas.

\begin{tabular}{|c|c|c|}
\hline Código & Localização & Uso atual do solo \\
\hline AG-13 & $\begin{array}{l}\text { "Lixão" municipal, Estr. Sta. Catarina km 1- } \\
\text { Biritiba-Mirim }\end{array}$ & Depósito de resíduos sólidos diversos. \\
\hline AR-06 & $\begin{array}{l}\text { Jardim Nova Marilda ou Marilda II, Santo } \\
\text { Amaro- São Paulo }\end{array}$ & $\begin{array}{l}\text { Habitações de baixa renda em antigas frentes de lavra e depósitos secos } \\
\text { de antigas bacias de decantação de rejeitos finos }\end{array}$ \\
\hline AR-16 & $\begin{array}{l}\text { Antiga Mineração Alberto Giosa, Rodovia } \\
\text { Régis Bittencourt km 282- Embu }\end{array}$ & $\begin{array}{l}\text { Depósito de lixo e lançamento de esgotos "in natura" em lago } \\
\text { remanescente de bacia de decantação de rejeitos finos }\end{array}$ \\
\hline AR-20 & Jardim Noronha, Santo Amaro- São Paulo & $\begin{array}{l}\text { Habitações de baixa renda em depósitos secos de antigas bacias de } \\
\text { decantação de rejeitos finos }\end{array}$ \\
\hline AR-21 & Jardim Sabiá, Santo Amaro- São Paulo & $\begin{array}{l}\text { Habitações de baixa renda, depósito de lixo e lançamento de esgotos "in } \\
\text { natura" em lago remanescente de bacia de decantação de rejeitos finos }\end{array}$ \\
\hline AR-22 & $\begin{array}{l}\text { Jardim Marilda ou Marilda I, Santo Amaro- } \\
\text { São Paulo }\end{array}$ & $\begin{array}{l}\text { Habitações de baixa renda em encostas íngremes de antigas frentes de } \\
\text { lavra }\end{array}$ \\
\hline AR-23 & Jardim Maringá, Santo Amaro- São Paulo & $\begin{array}{l}\text { Habitações de baixa renda em antigas frentes de lavra, depósito de lixo e } \\
\text { lançamento de esgotos "in natura" em lago remanescente de bacia de } \\
\text { rejeitos finos }\end{array}$ \\
\hline \multirow[t]{4}{*}{ AR-29 } & \multirow[t]{4}{*}{ Lago de Carapicuíba- Carapicuíba/Barueri } & $\begin{array}{l}\text { Depósito de resíduos inertes (entulhos de demolição) em taludes } \\
\text { marginais do lago, próximo ao Centro de Carapicuíba }\end{array}$ \\
\hline & & $\begin{array}{l}\text { Depósito de sedimentos dragados e bota-fora de material (rochoso e } \\
\text { terroso) proveniente das obras de aprofundamento da calha do rio Tietê, } \\
\text { ambos nos taludes marginais do lago, próximos à Rodovia Castelo } \\
\text { Branco }\end{array}$ \\
\hline & & $\begin{array}{l}\text { "Lixão"/depósito de resíduos sólidos diversos situado na margem sul do } \\
\text { lago }\end{array}$ \\
\hline & & Habitações de baixa renda/favela na margem sul do lago \\
\hline \multirow[t]{2}{*}{ AR-37 } & \multirow[t]{2}{*}{ 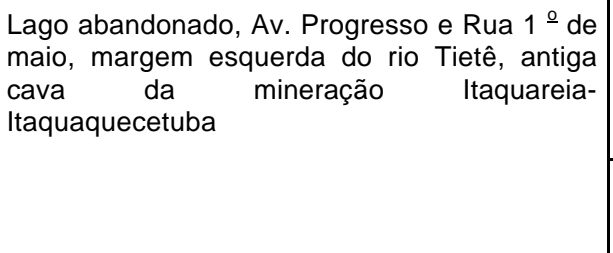 } & Depósito de entulhos e resíduos sólidos diversos \\
\hline & & $\begin{array}{l}\text { Habitações de baixa renda/favela na circunvizinhança e nas margens do } \\
\text { lago }\end{array}$ \\
\hline AR-42 & "Lixão" municipal, Volta Fria- Mogi das Cruzes & Depósito de resíduos sólidos diversos \\
\hline BT-34 & $\begin{array}{l}\text { "Lixão" de Itapevi, em setor da antiga Pedreira } \\
\text { São João }\end{array}$ & Depósito de resíduos sólidos diversos \\
\hline BT-35 & $\begin{array}{l}\text { "Lixão" de Guarulhos, em setor da antiga } \\
\text { Pedreira Aidar, Estrada da Barrocada s/n, Vila } \\
\text { Galvão- São Paulo/Guarulhos }\end{array}$ & Depósito de resíduos sólidos diversos \\
\hline $\mathrm{FI}-01$ & $\begin{array}{l}\text { "Lixão" municipal, Estr. dos Romeiros s/n- } \\
\text { Pirapora do Bom Jesus }\end{array}$ & Depósito de resíduos sólidos diversos. \\
\hline
\end{tabular}

Obs.: AG- argila; AR- areia; BT- brita; FI- filito. 
Entre os tipos de uso atual do solo freqüentes em áreas degradadas por mineração e ocupadas de forma desordenada, ocorrem particularmente habitações de baixa renda e depósitos de resíduos a céu aberto ou em lagos remanescentes da atividade mineral. Os depósitos de resíduos apresentam um ligeiro predomínio quando comparados æ̀s habitações de baixa renda (TABELA 6.3).

TABELA 6.3- Antigas áreas de mineração atualmente ocupadas de forma desordenada, segundo o uso atual do solo e o bem mineral anteriormente explotado.

\begin{tabular}{|c|c|c|c|c|c|c|c|c|}
\hline \multicolumn{2}{|c|}{ Uso atual do solo } & \multicolumn{4}{|c|}{ Bem mineral explotado } & \multicolumn{3}{|c|}{ Total } \\
\hline & & Argila & Areia & Brita & Filito & № & & \\
\hline \multicolumn{2}{|c|}{ Habitação de baixa renda } & - & 7 & - & - & 7 & 41 & 41 \\
\hline \multirow{2}{*}{$\begin{array}{l}\text { Depósito de } \\
\text { resíduos }\end{array}$} & a céu aberto & 1 & 2 & 2 & 1 & 6 & 35 & \multirow[b]{2}{*}{59} \\
\hline & em lago & - & 4 & - & - & 4 & 24 & \\
\hline \multicolumn{2}{|c|}{ Total } & 1 & 13 & 2 & 1 & 17 & \multicolumn{2}{|c|}{100} \\
\hline
\end{tabular}

O uso preferencial na ocupação de baixa renda é por loteamentos, geralmente estabelecidos em um período de tempo relativamente curto. Os depósitos de resíduos abrigam materiais de origem diversa, em especial lixo doméstico e industrial, entulho de obras de demolição e construção e civil e sedimentos dragados de rios e córregos em obras de desassoreamento. Os materiais têm sido dispostos tanto a céu aberto quanto em lagos abandonados. Em ambas formas de ocupação desordenada, habitação e disposição de resíduos, o uso evidencia uma demanda significativa por terrenos para estas finalidades na RMSP (FOTOS 70 a 75).

Estas áreas se caracterizam pela diversidade de processos de degradação instalados, alguns dos quais iniciados desde antes da desativação da mineração. No caso de habitações em morros, são flagrantes os riscos a que estão sujeitas as populações moradoras, particularmente em face da alta suscetibilidade a erosão e escorregamentos existente nestas situações, localmente agravados pela presença de inúmeros blocos rochosos instáveis. Em áreas baixas, convive-se com alagamentos. Outros processos são decorrentes de fatores associados à ocupação desordenada, como a geração e lançamento de lixo doméstico e esgotos "in natura" no âmbito e imediações da própria área, bem como a jusante, onde os lagos preexistentes se tornam receptores desses materiais. 


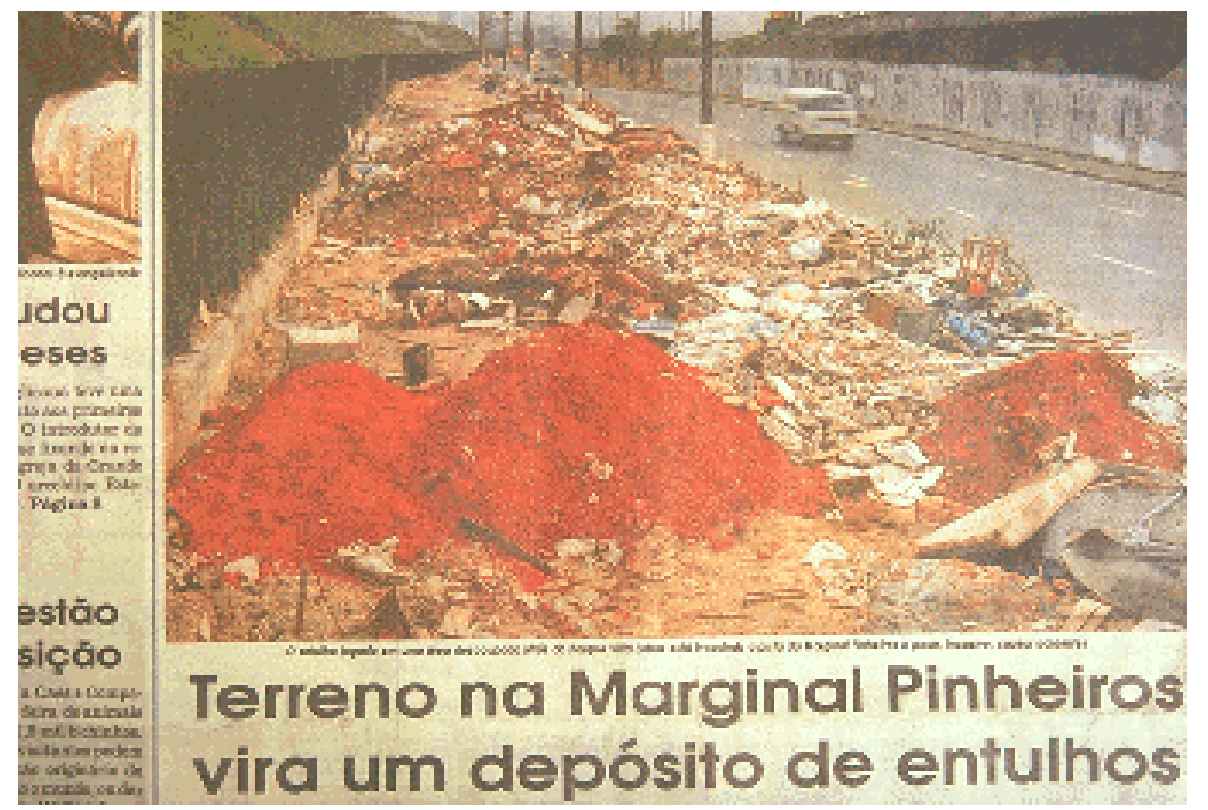

FOTO 70 - Notícia em jornal de bairro ("O Butantã"), ilustrando a carência de áreas para disposição de resíduos na cidade de São Paulo.

Av. Marginal Pinheiros, São Paulo.

FOTO 71 - Depósito de resíduos sólidos na margem e no lago de antiga extração de areia. Ao fundo, instabilizações na frente de lavra desativada.

Antiga mineração de areia Giosa,

Embu ( AR-16).
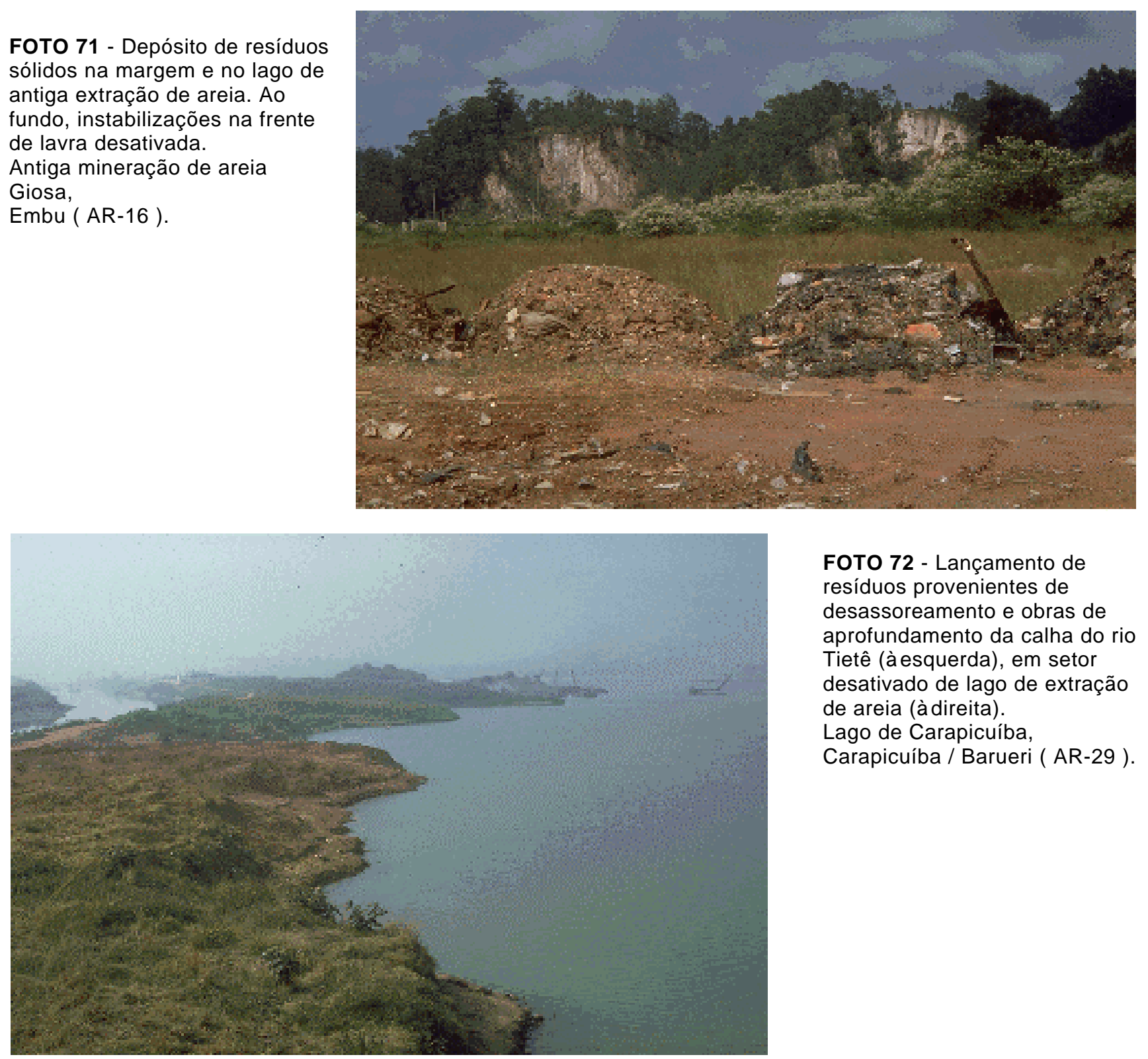

FOTO 72 - Lançamento de resíduos provenientes de desassoreamento e obras de aprofundamento da calha do rio Tietê (à esquerda), em setor desativado de lago de extração de areia (àdireita).

Lago de Carapicuíba, Carapicuíba / Barueri ( AR-29). 


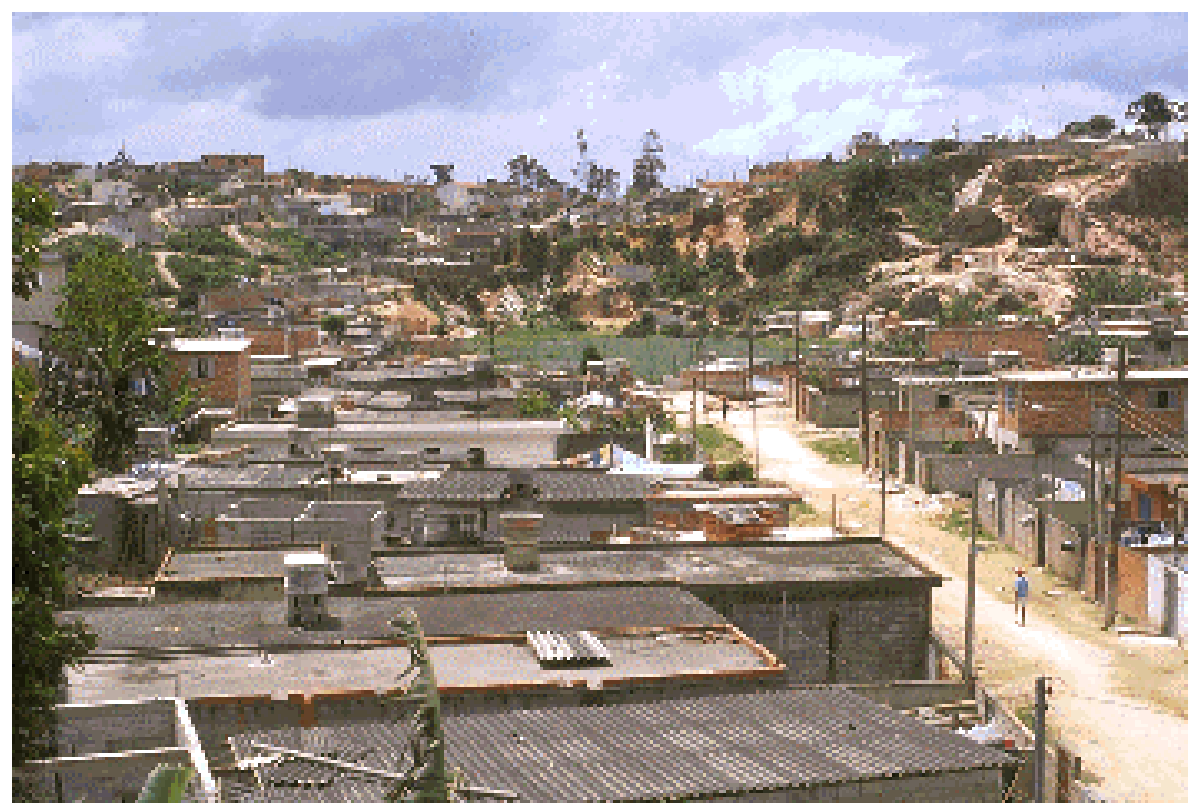

FOTO 73 - Ocupação

habitacional de baixa renda em antiga frente de lavra de areia em morro (ao fundo) e lançamento de esgotos em lago remanescente da atividade mineral (ao centro).

Jardim Marilda,

São Paulo ( AR-06 ).
FOTO 74 - Ocupação

habitacional de baixa renda em frente de lavra de areia desativada no final dos anos 80 , com depósito de lixo e lançamento de esgotos em lago remanescente da atividade mineral.

Jardim Sabiá, São Paulo ( AR-21).

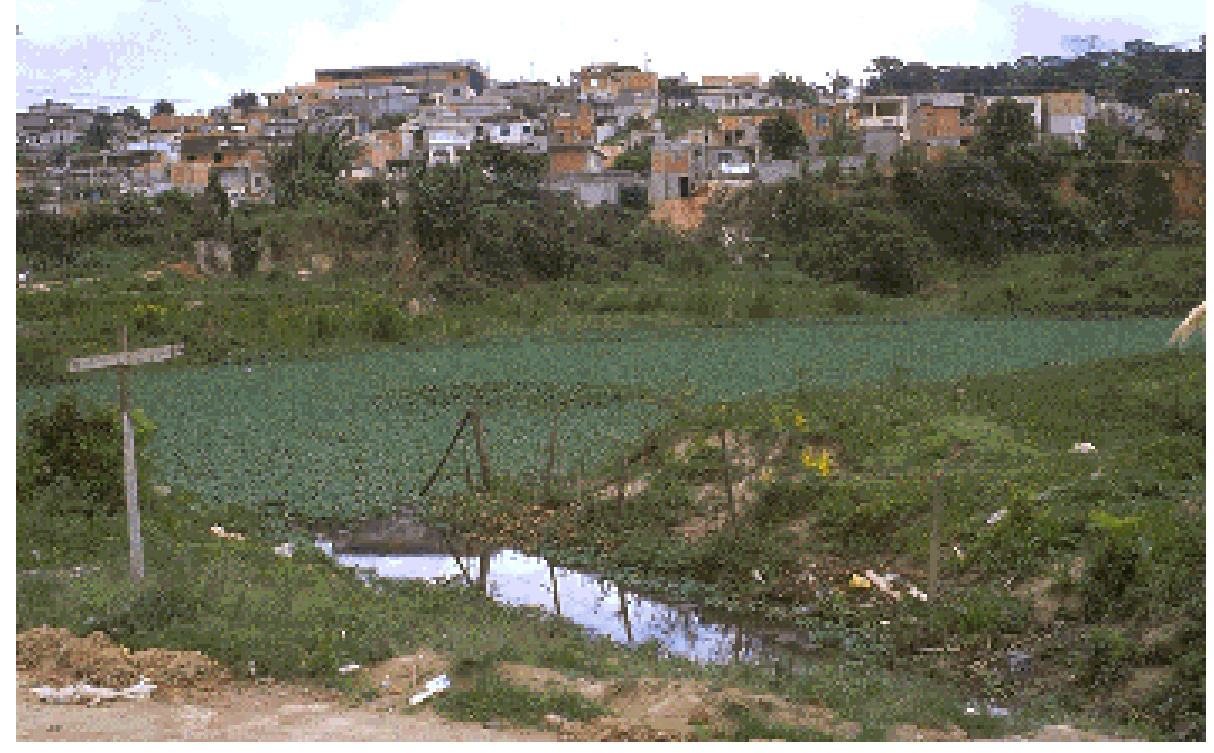

FOTO 75 - Habitações em loteamento de baixa renda em depósitos secos de antiga bacia de decantação de rejeitos finos provenientes de extração e beneficiamento de areia da antiga Mineração Devechi \& Devechi.

Jardim Noronha,

São Paulo ( AR-20 ). 


\subsubsection{Reabilitação planejada}

Após o encerramento da atividade mineral, muitas áreas degradadas por mineração na RMSP têm sido objeto de projetos que visam a instalação planejada de uma forma de uso e a reabilitação urbana dos terrenos. O levantamento efetuado revela uma diversidade de usos pós-mineração executados de maneira planejada na RMSP (TABELA 6.4 e FIGURA 6.3). A freqüência e proporcionalidade entre os diferentes tipos nas áreas estudadas são ilustrados na TABELA 6.5.

Análise comparativa entre os tipos de usos planejados em minas ativas e desativadas na RMSP, segundo os Planos de Recuperação de Áreas Degradadas- Prads elaborados e apresentados aos órgãos ambientais (v. TABELA 4.2) e os usos que correspondem a áreas em que efetivamente se implementou um projeto de reabilitação ( $v$. TABELA 6.5), revela algumas contradições. Nos Prads, observam-se alguns tipos de usos não encontrados no levantamento de campo realizado, como: preservação ou conservação ambiental (este, como o segundo tipo mais citado nos Prads); pastagem, horticultura e atividades agrícolas; reflorestamento comercial; aeroclube; chácara de lazer; campo de golfe; tratamento de esgotos; e manancial hídrico para abastecimento. Por outro lado, existem áreas reabilitadas ou em processo de reabilitação que abrigam usos não contemplados em Prads, como: sistema viário; educação; e clube recreativo privado.

Em geral, as intenções de usos manifestadas pelos empreendedores nos Prads abrangem uma diversidade maior de tipos de uso do solo do que aquela efetivamente implementada. Entre os usos predominantes em ambos, Prads e projetos de reabilitação executados, destacam-se: lazer, recreação e esportes comunitários; indústria e comércio; e habitação e loteamento. Em contraposição, ressalta-se o fato de que o uso mais freqüente em projetos executados é o de disposição de resíduos, o qual, por sua vez, é um dos menos citados em Prads.

Entre outros fatores, um dos condicionantes mais importantes na definição do uso parece estar relacionado ao caráter público ou privado do projeto de reabilitação, bem como às suas interações com a questão da propriedade do solo em meio æ̀s contínuas transformaçôes do contexto metropolitano. A construção de um projeto de uma obra do sistema viário, por exemplo, tem sido exclusivamente de motivação pública, o mesmo ocorrendo com a instalação de um manancial hídrico para abastecimento público. Outros usos, como indústria e comércio, correspondem a projetos de iniciativa privada. Outro aspecto está no fato de que os Prads se referem ao contexto urbano atual, enquanto a maior parte dos projetos de reabilitação executados teve sua concepação e implementação iniciada há algumas décadas. 
TABELA 6.4- Relação das antigas áreas de mineração reabilitadas ou em processo de reabilitação e estudadas.

\begin{tabular}{|c|c|c|c|c|}
\hline Código & Empreendimento & $\begin{array}{c}\text { Uso do solo e } \\
\text { época de instalação }\end{array}$ & Promotor & Localização \\
\hline AG-04 & $\begin{array}{l}\text { Complexo Viário Escola de } \\
\text { Mackenzie }\left(^{*}\right)\end{array}$ & $\begin{array}{l}- \text { Sistema viário } \\
-1995\end{array}$ & $\begin{array}{l}\text { Prefeitura } \\
\text { municipal }\end{array}$ & Sacomã- São Paulo \\
\hline AG-07 & $\begin{array}{l}\text { Pátio baixo da General Motors do } \\
\text { Brasil S.A. }\end{array}$ & $\begin{array}{l}\text {-Indústria } \\
\text {-Década de } 20\end{array}$ & $\begin{array}{l}\text { Empresa } \\
\text { privada }\end{array}$ & Av. Goiás s/n- São Caetano do Sul \\
\hline AG-08 & Cerâmica São Caetano Ltda. & $\begin{array}{l}\text {-Indústria } \\
\text {-Desde } 1923\end{array}$ & $\begin{array}{l}\text { Empresa } \\
\text { privada }\end{array}$ & $\begin{array}{l}\text { R. Casemiro de Abreu 04- Sào Caetano } \\
\text { do Sul }\end{array}$ \\
\hline AG-09 & Centro de Convivência Municipal & $\begin{array}{l}\text {-Lazer, esportes comunitários, creche } \\
\text {-Desde } 1975\end{array}$ & $\begin{array}{l}\text { Prefeitura } \\
\text { municipal }\end{array}$ & Bairro Cerâmica- São Caetano do Sul \\
\hline AG-10 & Fábrica da Volkswagen do Brasil S.A. & $\begin{array}{l}\text {-Indústria } \\
\text {-Desde } 1954\end{array}$ & $\begin{array}{l}\text { Empresa } \\
\text { privada }\end{array}$ & $\begin{array}{l}\text { Rodovia Anchieta, km 25- São Bernardo } \\
\text { do Campo }\end{array}$ \\
\hline AG-11 & Postos de gasolina & $\begin{array}{l}- \text { Comércio } \\
-1975\end{array}$ & $\begin{array}{l}\text { Empresa } \\
\text { Privada }\end{array}$ & $\begin{array}{l}\text { Esquina dos três postos- São Caetano do } \\
\text { Sul }\end{array}$ \\
\hline AG-14 & Colégio Santa Cruz & $\begin{array}{l}\text { - Colégio, educação } \\
\text {-Década de } 50\end{array}$ & $\begin{array}{l}\text { Empresa } \\
\text { privada }\end{array}$ & $\begin{array}{l}\text { Av. Arruda Botelho, Alto de Pinheiros- } \\
\text { São Paulo }\end{array}$ \\
\hline AG-12 & City Butantã & $\begin{array}{l}\text {-Habitação, loteamento } \\
\text {-Década de } 60\end{array}$ & $\begin{array}{l}\text { Empresa } \\
\text { privada }\end{array}$ & Butantã- São Paulo \\
\hline AR-09 & Lagos do Parque do Ibirapuera & $\begin{array}{l}\text {-Lazer, recreação e esportes comunitários } \\
-1954\end{array}$ & $\begin{array}{l}\text { Prefeitura } \\
\text { municipal }\end{array}$ & $\begin{array}{l}\text { Av. Pedro Álvares Cabral s/n, Ibirapuera- } \\
\text { São Paulo }\end{array}$ \\
\hline AR-10 & Galpões industriais da Sarp $\left(^{*}\right)$ & $\begin{array}{l}\text {-Indústria } \\
\text {-Década de } 80\end{array}$ & $\begin{array}{l}\text { Empresa de } \\
\text { mineração }\end{array}$ & $\begin{array}{l}\begin{array}{l}\text { Rodovia Castelo } \\
\text { Jandira- Barueri }\end{array} \\
\end{array}$ \\
\hline AR-11 & Raia Olímpica da USP & $\begin{array}{l}\text {-Educação e esportes } \\
\text {-Década de } 60\end{array}$ & $\begin{array}{l}\text { Governo } \\
\text { estadual }\end{array}$ & $\begin{array}{l}\text { Av. Prof. Mello Moraes, } \\
\text { Universitária, São Paulo }\end{array}$ \\
\hline AR-12 & $\begin{array}{l}\text { Parque Ecológico do Tietê- Centro } \\
\text { Recreativo de Cangaíba }\left(^{*}\right)\end{array}$ & $\begin{array}{l}\text {-Lazer, recreação, esportes comunitários e dispos. } \\
\text { de sedimentos; área: } 1.360 .000 \mathrm{~m}^{2} \\
\text {-Década de } 70\end{array}$ & $\begin{array}{l}\text { Governo } \\
\text { estadual }\end{array}$ & $\begin{array}{l}\text { Rodovia Ayrton Senna- São Paulo e } \\
\text { Guarulhos }\end{array}$ \\
\hline AR-13 & Parque Cidade de Toronto & $\begin{array}{l}\text {-Lazer, recreação e esportes comunitários; área: } \\
110.000 \mathrm{~m}^{2} \text { ( } 70 \% \text { de lago); custo: US } \$ 1,5 \text { milhão } \\
-1992\end{array}$ & $\begin{array}{l}\text { Prefeitura } \\
\text { municipal }\end{array}$ & $\begin{array}{l}\text { Av. Cardeal Motta s/n, Pirituba- São } \\
\text { Paulo }\end{array}$ \\
\hline AR-14 & $\begin{array}{l}\text { Aterro Sanitário de Mauá }\left({ }^{*}\right) \\
\text { (antigas areeiras Lara-Sertãozinho) }\end{array}$ & $\begin{array}{l}\text {-Disposição de resíduos sólidos;área: } 375.000 \mathrm{~m}^{2} \\
-1987\end{array}$ & $\begin{array}{l}\text { Prefeitura } \\
\text { municipal }\end{array}$ & Av. João XXXIII s/n- Mauá \\
\hline AR-27 & $\begin{array}{l}\text { Aterro Sanitário Santo Amaro }\left(^{*}\right) \\
\text { (antiga areeira do Viterbo) }\end{array}$ & $\begin{array}{l}\text {-Disposição de resíduos sólidos } \\
\text {-Década de } 60\end{array}$ & $\begin{array}{l}\text { Prefeitura } \\
\text { municipal }\end{array}$ & Av. das Nações Unidas- São Paulo \\
\hline AR-28 & $\begin{array}{l}\text { Parque Villalobos (precedido de } \\
\text { aterros de resíduos inertes) }\left(^{*}\right)\end{array}$ & $\begin{array}{l}\text {-Lazer, recreação e esportes comunitários, } \\
\text {-1965 (aterros) e desde } 1992 \text { (Parque) }\end{array}$ & $\begin{array}{l}\text { Governo } \\
\text { estadual }\end{array}$ & $\begin{array}{l}\text { Av. Prof. Fonseca Rodrigues s/n, Alto de } \\
\text { Pinheiros- São Paulo }\end{array}$ \\
\hline AR-30 & Chácara Santo Antônio & $\begin{array}{l}\text { - Loteamento, habitação } \\
\text {-Década de } 50\end{array}$ & $\begin{array}{l}\text { Empresa } \\
\text { privada }\end{array}$ & Santo Amaro- São Paulo \\
\hline AR-31 & $\begin{array}{ll}\text { Jardim Universidade/City } & \text { Boaçava } \\
\text { (parte baixa) }\end{array}$ & $\begin{array}{l}\text {-Loteamento, habitação } \\
\text {-Década de } 50\end{array}$ & $\begin{array}{l}\text { Empresa } \\
\text { privada }\end{array}$ & Alto de Pinheiros- São Paulo \\
\hline AR-32 & $\begin{array}{l}\text { Recanto Gaúcho (antigo porto de areia } \\
\text { do Viterbo) }\end{array}$ & $\begin{array}{l}\text {-Comércio, Restaurante } \\
\text {-Década de } 70\end{array}$ & $\begin{array}{l}\text { Empresa de } \\
\text { mineração }\end{array}$ & $\begin{array}{l}\text { Rodovia Régis Bittencourt } \mathrm{km} \quad 286- \\
\text { Itapecerica da Serra }\end{array}$ \\
\hline AR-33 & Trevo de Itapecerica & $\begin{array}{l}\text {-Sistema rodoviário } \\
\text {-Década de } 70\end{array}$ & $\begin{array}{l}\text { Governo } \\
\text { federal }\end{array}$ & $\begin{array}{l}\text { Rodovia Régis Bittencourt } \mathrm{km} \mathrm{286-} \\
\text { Itapecerica da Serra }\end{array}$ \\
\hline AR-35 & Vila Maria Baixa & $\begin{array}{l}\text {-Habitação, loteamento } \\
\text {-Década de } 40\end{array}$ & $\begin{array}{l}\text { Empresa } \\
\text { Privada }\end{array}$ & $\begin{array}{l}\text { Av. guilherme Cotching, Vila Maria- São } \\
\text { Paulo }\end{array}$ \\
\hline AR-36 & $\begin{array}{lll}\begin{array}{l}\text { Pesque-pague } \\
\text { Silva) (*) }\end{array} & \text { (antiga } & \text { Mineração } \\
\end{array}$ & $\begin{array}{l}\text {-Pesca recreativa em lagos } \\
\text {-Desde } 1994\end{array}$ & $\begin{array}{l}\text { Empresa } \\
\text { privada }\end{array}$ & $\begin{array}{l}\text { Antiga Estr. Gurulhos -Arujá ou Estr. } \\
\text { Jaguari s/n- Arujá }\end{array}$ \\
\hline AR-38 & Praça Bento de Camargo Barros & $\begin{array}{l}\text {-Lazer } \\
\text {-Década de } 60\end{array}$ & $\begin{array}{l}\text { Prefeitura } \\
\text { municipal }\end{array}$ & Ponte Grande- São Paulo \\
\hline AR-39 & Supermercado Paes Mendonça & $\begin{array}{l}\text {-Comércio } \\
\text {-Década de } 80\end{array}$ & $\begin{array}{l}\text { Empresa } \\
\text { Privada }\end{array}$ & $\begin{array}{l}\text { Av. Marginal Pinheiros, Morumbi- São } \\
\text { Paulo }\end{array}$ \\
\hline AR-40 & $\begin{array}{l}\text { Associação Atlética Portuguesa de } \\
\text { Desportos (antigo aterro de entulho) }\end{array}$ & $\begin{array}{l}\text { - Clube recreativo } \\
\text {-Década de } 40\end{array}$ & $\begin{array}{l}\text { Empresa } \\
\text { privada }\end{array}$ & Canindé- São Paulo \\
\hline AR-41 & $\begin{array}{l}\text { Conj. de edifícios (antigo porto de } \\
\text { areia Machado e Passini) }\end{array}$ & $\begin{array}{l}\text {-Habitação, condomínios } \\
\text {-Década de } 70\end{array}$ & $\begin{array}{l}\text { Empresa } \\
\text { privada }\end{array}$ & $\begin{array}{l}\text { Av. Arruda Botelho, Alto de Pinheiros- } \\
\text { São Paulo }\end{array}$ \\
\hline AR-43 & $\begin{array}{l}\text { Aterro Industrial Boa Hora (antiga } \\
\text { Mineração Boa Hora) }\left({ }^{*}\right)\end{array}$ & $\begin{array}{l}\text {-Disposição de resíduos industriais (classe II); } \\
\text { área: } 300.000 \mathrm{~m}^{2} \\
\text { - Desde } 1993\end{array}$ & $\begin{array}{l}\text { Empresa } \\
\text { privada }\end{array}$ & Av. João XXIII s/n- Mauá \\
\hline BT-04 & $\begin{array}{l}\text { Centro Educacional e Esportivo do } \\
\text { Butantã }\end{array}$ & $\begin{array}{l}\text {-Lazer, recreação e esportes comunitários } \\
-1975\end{array}$ & $\begin{array}{l}\text { Prefeitura } \\
\text { municipal }\end{array}$ & $\begin{array}{l}\text { R. Dr. Ernani da Gama Correa, Butantã- } \\
\text { São Paulo }\end{array}$ \\
\hline BT-05 & Aterro Sanitário de Vila Albertina $\left(^{*}\right)$ & $\begin{array}{l}\text {-Disposição de resíduos domiciliares } \\
\text {-Desde } 1987\end{array}$ & $\begin{array}{l}\text { Prefeitura } \\
\text { municipal }\end{array}$ & $\begin{array}{l}\text { Estrada Santa Maria, Tremembé- São } \\
\text { Paulo }\end{array}$ \\
\hline$\overline{B T-06}$ & Aterro Sanitário Jacuí $\left({ }^{*}\right)$ & $\begin{array}{l}\text {-Disposição de resíduos domiciliares } \\
\text {-Desde } 1980\end{array}$ & $\begin{array}{l}\text { Prefeitura } \\
\text { municipal }\end{array}$ & $\begin{array}{l}\text { Rua Arareua s/n, São Miguel Paulista- } \\
\text { São Paulo }\end{array}$ \\
\hline BT-07 & Aterro Itatinga $\left(^{*}\right)$ & $\begin{array}{l}\text {-Disposição de resíduos inertes } \\
\text {-Desde } 1990\end{array}$ & $\begin{array}{l}\text { Prefeitura } \\
\text { municipal }\end{array}$ & $\begin{array}{l}\text { Rua Aniquis s/n, Santo Amaro- São } \\
\text { Paulo }\end{array}$ \\
\hline BT-10 & Aterro Itaberaba/Vega-Sopave $\left(^{*}\right)$ & $\begin{array}{l}\text {-Disposição de resíduos industriais (classe I e II) } \\
\text {-Década de } 80\end{array}$ & $\begin{array}{l}\text { Empresa } \\
\text { privada }\end{array}$ & São Paulo \\
\hline BT-17 & $\begin{array}{l}\text { Depósito de materiais de construção } \\
\text { Madeirense }\end{array}$ & $\begin{array}{l}\text {-Comércio } \\
-1989\end{array}$ & $\begin{array}{l}\text { Empresa } \\
\text { privada }\end{array}$ & Tremembé- São Paulo \\
\hline BT-18 & Supermercado Bergamini & $\begin{array}{l}\text {-Comércio } \\
\text {-Década de } 70\end{array}$ & $\begin{array}{l}\text { Empresa } \\
\text { privada }\end{array}$ & Vila Santa TerezinhaSão Paulo \\
\hline BT-29 & $\begin{array}{l}\text { Cohab Jandira (setor da antiga } \\
\text { Pedreira São João) }\left(^{*}\right)\end{array}$ & $\begin{array}{l}\text {-Habitação } \\
\text {-Década de } 80\end{array}$ & $\begin{array}{l}\text { Governo } \\
\text { estadual }\end{array}$ & Jandira \\
\hline BT-30 & Aterro Sanitário Sapopemba $\left(^{*}\right)$ & $\begin{array}{l}\text {-Disposição de resíduos } \\
-1979\end{array}$ & $\begin{array}{l}\text { Prefeitura } \\
\text { municipal }\end{array}$ & $\begin{array}{l}\text { Av. Sapopemba s/n, Sapopemba- São } \\
\text { Paulo }\end{array}$ \\
\hline BT-31 & Parque São Domingos & $\begin{array}{l}\text {-Lazer, recreação e esportes comunitários } \\
\text {-Década de } 80\end{array}$ & $\begin{array}{l}\text { Prefeitura } \\
\text { municipal }\end{array}$ & $\begin{array}{l}\text { R. Pedro Sernagiotto 125, Pirituba- São } \\
\text { Paulo }\end{array}$ \\
\hline BT- 32 & Aterro Sanitário São Matheus $\left({ }^{*}\right)$ & $\begin{array}{l}\text {-Disposição de resíduos } \\
-1984\end{array}$ & $\begin{array}{l}\text { Prefitura } \\
\text { municipal }\end{array}$ & $\begin{array}{l}\text { Marginal do Córrego Fazenda Velha, São } \\
\text { Matheus- São Paulo }\end{array}$ \\
\hline BT-33 & Aterro Sanitário Bandeirantes $\left(^{*}\right)$ & 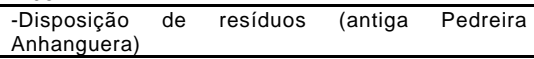 & $\begin{array}{l}\text { Prefeitura } \\
\text { municipal }\end{array}$ & $\begin{array}{l}\text { Rodovia dos Bandeirantes s/n, Perus- } \\
\text { São Paulo }\end{array}$ \\
\hline $\mathrm{KI}-04$ & $\begin{array}{l}\text { Pousada e Churrascaria Serra Verde } \\
\left({ }^{*}\right)\end{array}$ & $\begin{array}{l}\text { - Hotelaria e restaurante } \\
\text {-Década de } 80\end{array}$ & $\begin{array}{l}\text { Empresa } \\
\text { privada }\end{array}$ & $\begin{array}{l}\text { Estrada Eng }{ }^{\circ} \text { Marcilac altura } 2.200, \text { Eng }^{\circ} \\
\text { Marcilac- São Paulo }\end{array}$ \\
\hline $\mathrm{KI}-08$ & Supermercado Carrefour & $\begin{array}{l}\text {-Comércio } \\
\text {-Década de } 80\end{array}$ & $\begin{array}{l}\text { Empresa } \\
\text { privada }\end{array}$ & Km 11, Via Anchieta, São Paulo \\
\hline
\end{tabular}

(*) projeto em execução ou parcialmente concluído em relação ao total da área degradada pela antiga mineração.

Obs.: os códigos AG- argila, AR- areia; BT- brita; KI- caulim, representam os bens minerais explotados à epoca em que as minerações se encontravam em atividade. 
FIGURA 6.3 - Localização das áreas reabilitadas estudadas na RMSP - Ver Pasta Desenhos 
TABELA 6.5- Áreas reabilitadas $\left({ }^{*}\right)$, segundo o uso atual do solo e o bem mineral anteriormente explotado.

\begin{tabular}{|c|c|c|c|c|c|c|}
\hline \multirow[t]{2}{*}{ Uso atual do solo } & \multicolumn{4}{|c|}{ Bem mineral explotado } & \multicolumn{2}{|c|}{ Total } \\
\hline & Argila & Areia & Brita & Caulim & № & $\%$ \\
\hline Disposição de resíduos & - & 03 & 07 & - & 10 & 24 \\
\hline Indústria, comércio & 04 & 03 & 02 & 01 & 10 & 24 \\
\hline Lazer, recreação e esportes comunitários & 01 & 05 & 02 & - & 08 & 21 \\
\hline Habitação, loteamento & 01 & 04 & 01 & - & 06 & 15 \\
\hline Sistema viário & 01 & 01 & - & - & 02 & 05 \\
\hline Educação & 01 & 01 & - & - & 02 & 05 \\
\hline Clube recreativo privado & - & 01 & - & - & 01 & 02 \\
\hline Hotelaria & - & - & - & 01 & 01 & 02 \\
\hline Piscicultura, pesca & - & 01 & - & - & 01 & 02 \\
\hline Total & 08 & 19 & 12 & 02 & 41 & 100 \\
\hline
\end{tabular}

(*) reabilitação concluída ou em andamento

\subsubsection{Instabilizações presentes}

Apesar da perspectiva de reabilitação preconizada pelos projetos executados, a instalação planejada de um uso pós-mineração na RMSP nem sempre tem significado o encerramento dos problemas de estabilidade ambiental. Ao contrário, algumas áreas acabaram abrigando usos que, em função de suas características e peculiariedades, têm exigido gerenciamento permanente e a implementação contínua de medidas severas de controle e estabilização.

Boa parte dos projetos de reabilitação implementados ainda convivem com problemas de estabilidade. Alguns foram executados sem uma prévia investigação do passivo ambiental e sem uma análise prospectiva sobre a possível evolução dos processos de degradação que poderiam persistir após a instalação do novo uso. Além disso, deixaram de considerar também a provável influência que aqueles processos poderiam ter sobre o funcionamento do próprio projeto. 
Entre outras situações com problemas de estabilidade, destacam-se os casos de pedreiras destinadas à instalação de aterros sanitários. Este tipo de empreendimento tem requerido contínuas e onerosas obras de drenagem de gases e líquidos visando assegurar a estabilidade geotécnica da massa de lixo existente (FOTO 76). Objetiva-se evitar a ocorrência de grandes rupturas, como se verificou nos casos dos aterros sanitários de Mauá (AR-14) e do Bandeirantes (BT-33), construídos respectivamente em antigas áreas de mineração de areia e de brita. Outro aspecto, nestes casos, está na atratividade que as imediações dos aterros sanitários exercem àocupação de baixa renda, dada a depreciação dos terrenos circunvizinhos, o que tem sido verificado em aterros sanitários como os do Jacuí (BT-06 ), Itatinga (BT-07), São Matheus (BT-32) e Vila Albertina (BT-05), este último em terrenos íngremes nas encostas da Serra da Cantareira, zona norte da cidade de São Paulo (FOTO 77). Há vários episódios de conflitos decorrentes das relações de vizinhança entre os dois usos.

Além da disposição de resíduos, as áreas planas de antigas pedreiras também têm sido utilizadas para a instalação de construções comerciais de grande porte, como supermercados e depósitos de materiais de construção, em situações relativamente mais estáveis. Todavia, alguns locais ainda enfrentam problemas com a instabilidade de massas rochosas, muitas vezes induzida pela infiltração e percolação de águas pluviais e servidas, mas comumente provocada pela presença de lascas e blocos instáveis e pelos riscos associados a eventuais quedas (FOTOS 78 a 82).

Em áreas de antigas extrações de areia aluvionar, cuja ocupação por empreendimentos de grande porte se tornou viável em razão dos aterros amplos executados nas cavas remanescentes, ainda persistem alguns problemas de drenagem. Os aspectos principais decorrem de alagamentos e inundações, dado o contexto aluvionar e de baixa declividade dos terrenos construídos (FOTO 83).

Instabilizações em cortes e aterros remanescentes de antigas extrações de areia ou de caulim também são freqüentes em obras de usos comercial e industrial, porém geralmente com dimensões e riscos relativamente menores (FOTOS 84 a 88).

Por outro lado, a maior parte dos projetos de áreas de lazer, recreação, esportes comunitários, construções habitacionais e loteamentos convive com problemas restritos de estabilidade. Além disso, revela modalidades de uso bastante favoráveis tanto à gerenciabilidade quanto à sustentabilidade e que têm sido bem sucedidos nas relações de equilíbrio com a circunvizinhança (FOTOS 89 a 94). Estes casos tendem a servir de referência para situações mais complexas (FOTO 95). As incertezas prendem-se aos casos em que a instalação do projeto foi precedida de deposição de resíduos diversos, incluindo sedimentos contaminados dragados nos canais dos rios Tietê e Pinheiros, como ocorreu, entre outros, na construção do Parque Villalobos em São Paulo (AR-28). 


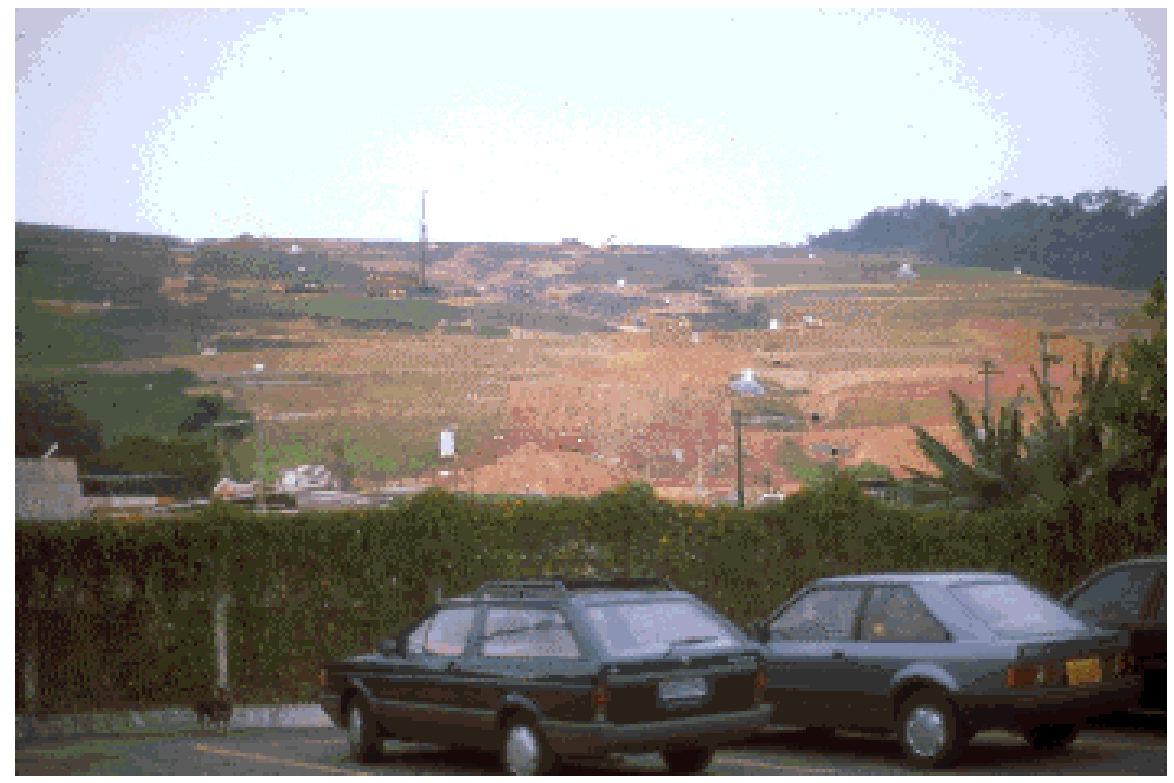

FOTO 76 - Aterro sanitário de Vila Albertina instalado em área da antiga Pedreira Cantareira, São Paulo ( BT-05 ).

FOTO 77 - Mesma área da foto anterior, destacando medidas e obras de estabilização (sistemas de drenos com canaletas revestidas de brita e telas de aço ). Ao fundo, ocupação de risco em expansão na Serra da Cantareira. Aterro sanitário de Vila Albertina, São Paulo ( BT-05 ).
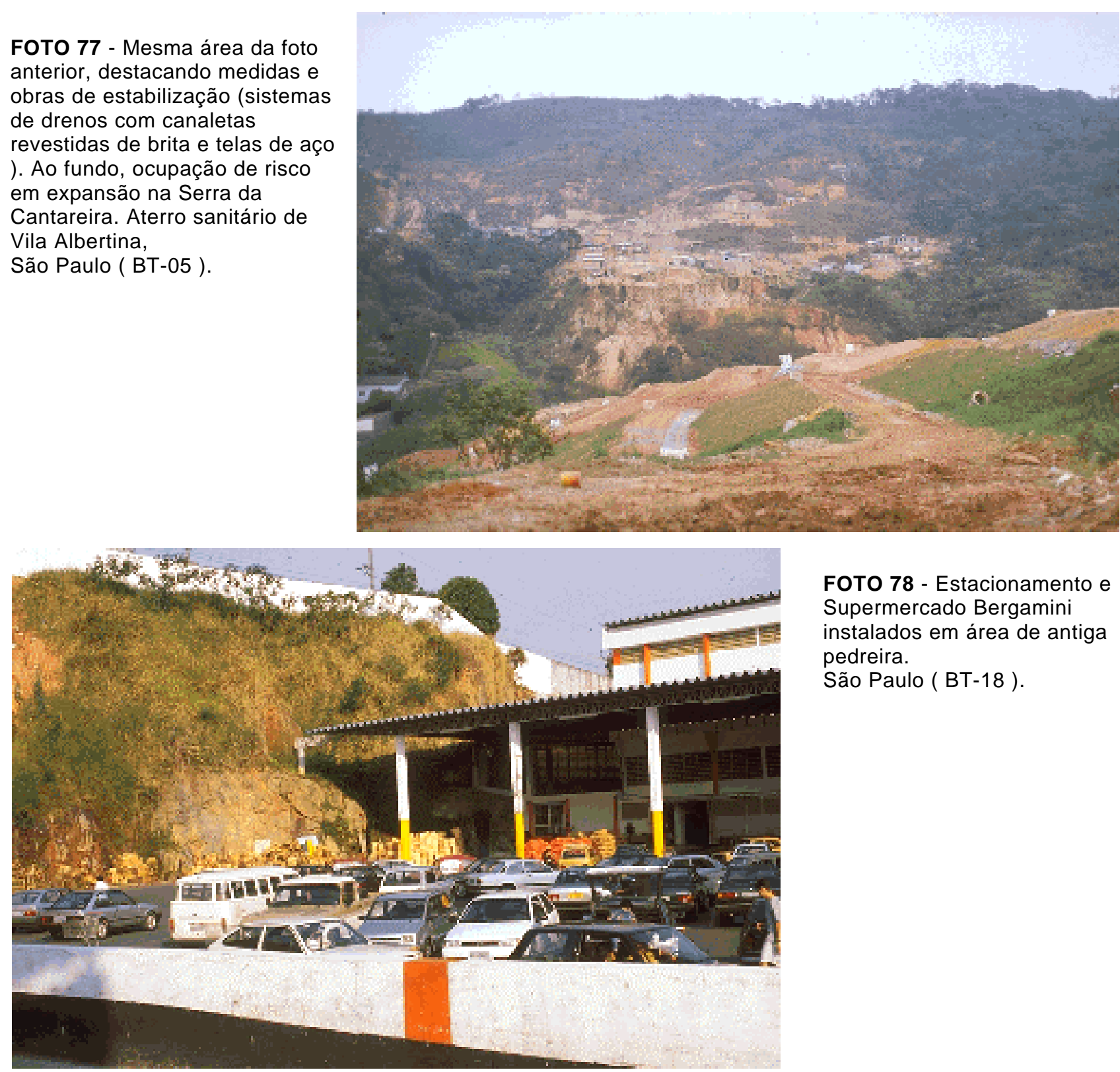

FOTO 78 - Estacionamento e Supermercado Bergamini instalados em área de antiga pedreira.

São Paulo ( BT-18). 


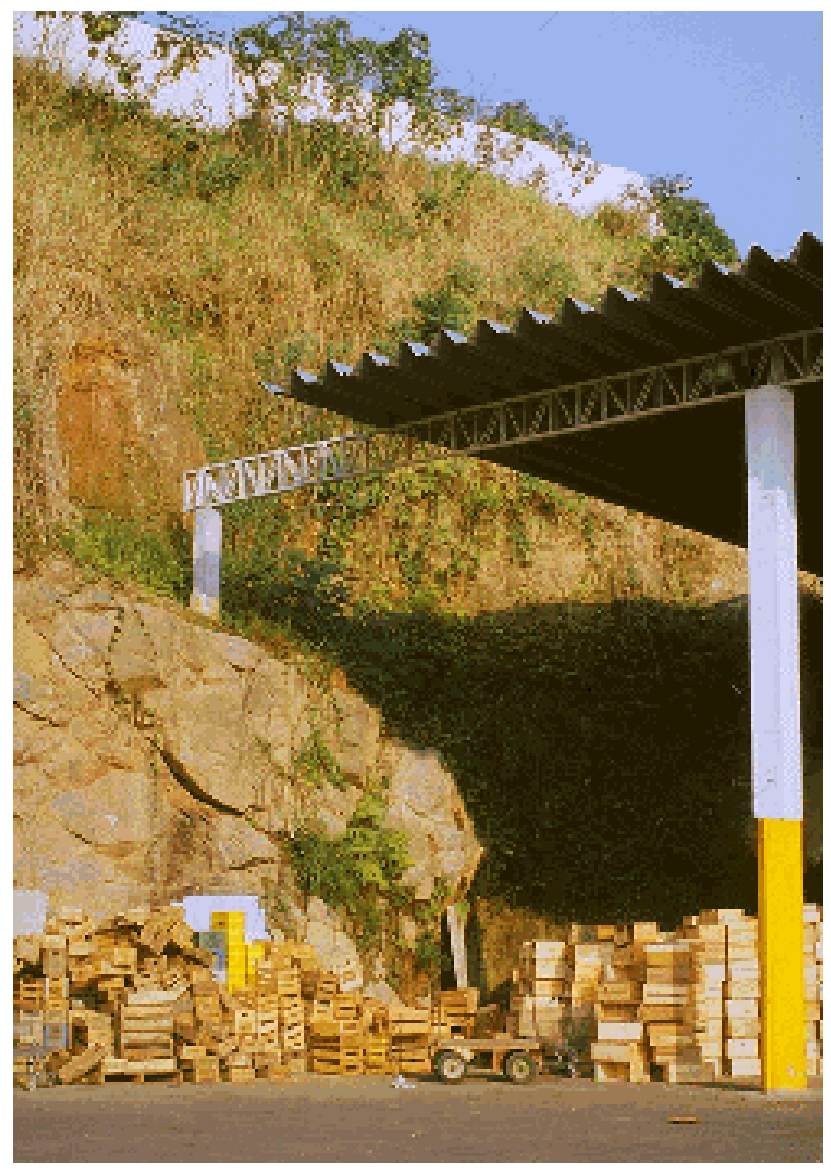

FOTO 79 - Mesma área da foto anterior, destacando evidências de instabilização e queda de blocos de rochas , São Paulo ( BT-18).

FOTO 80 - Mesma área das fotos anteriores, destacando evidências de infiltração d'água e instabilização em rochas, São Paulo ( BT-18 ).

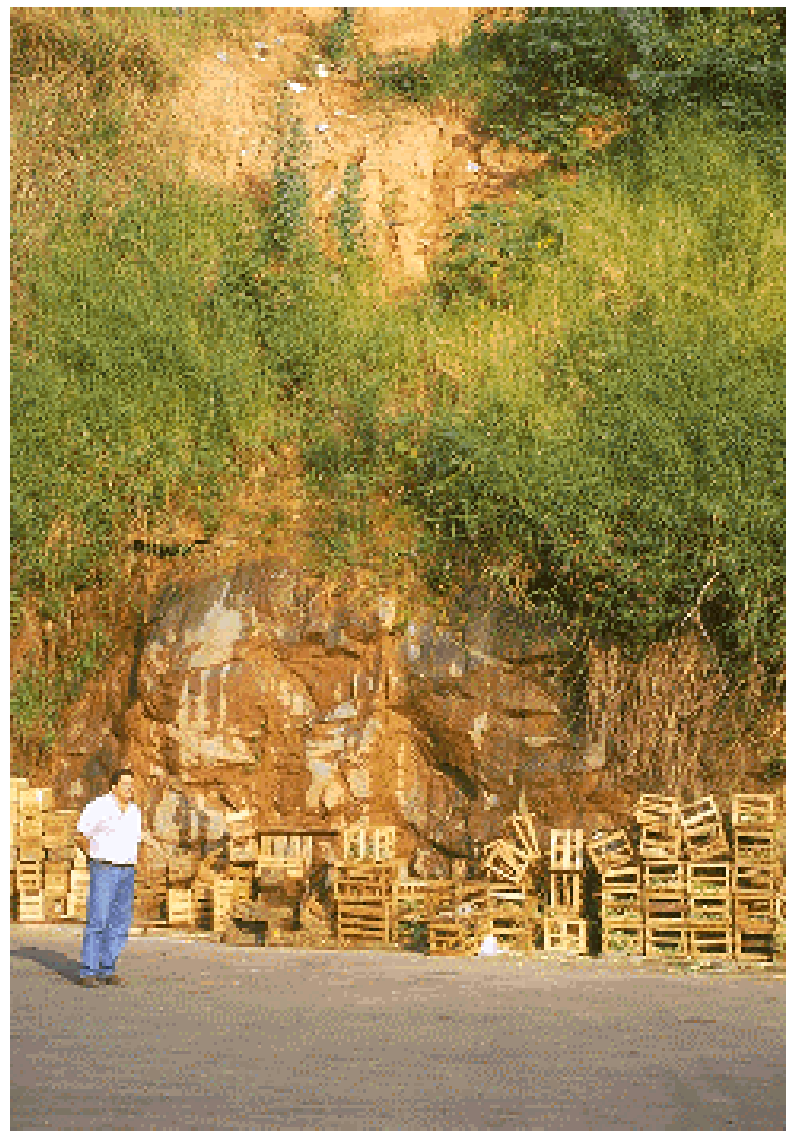




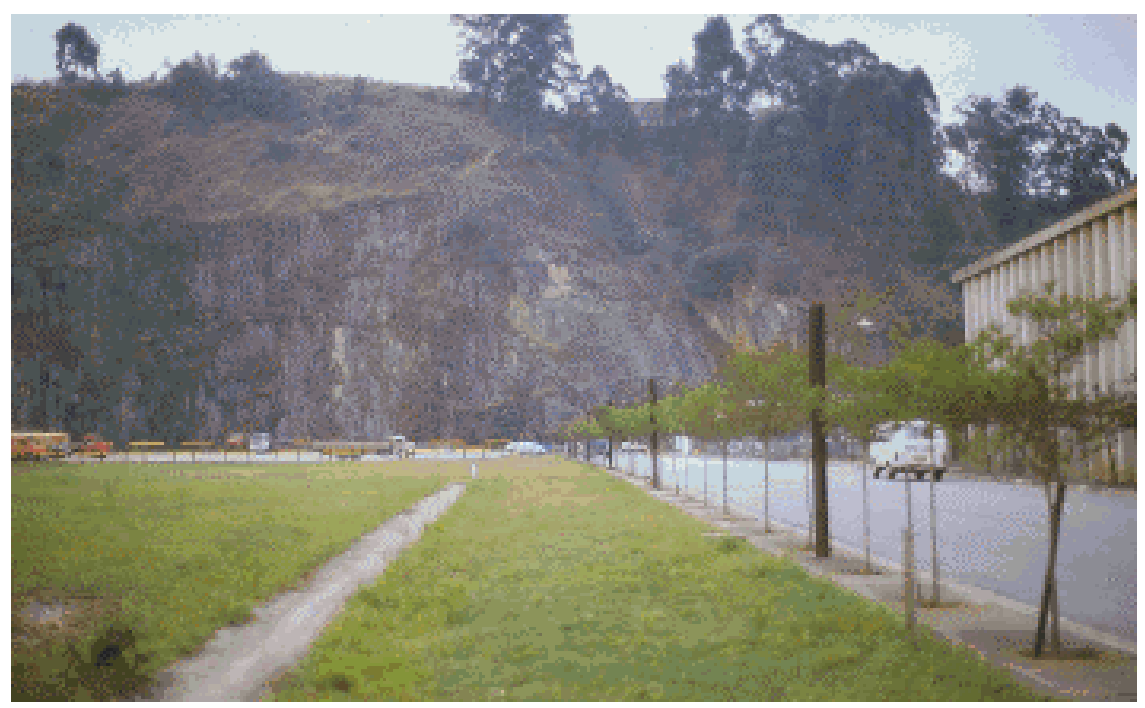

FOTO 81 - Estacionamento e depósito de materiais de construção Madeirense, instalado em área de antiga pedreira,

São Paulo ( BT-17 ).

FOTO 82 - Mesma área da foto anterior, destacando feições de instabilização e queda de blocos rochosos na antiga frente de lavra,com cerca de $10 \mathrm{~m}$ de altura. Abaixo, a sinalização de advertência.

São Paulo ( BT-17).
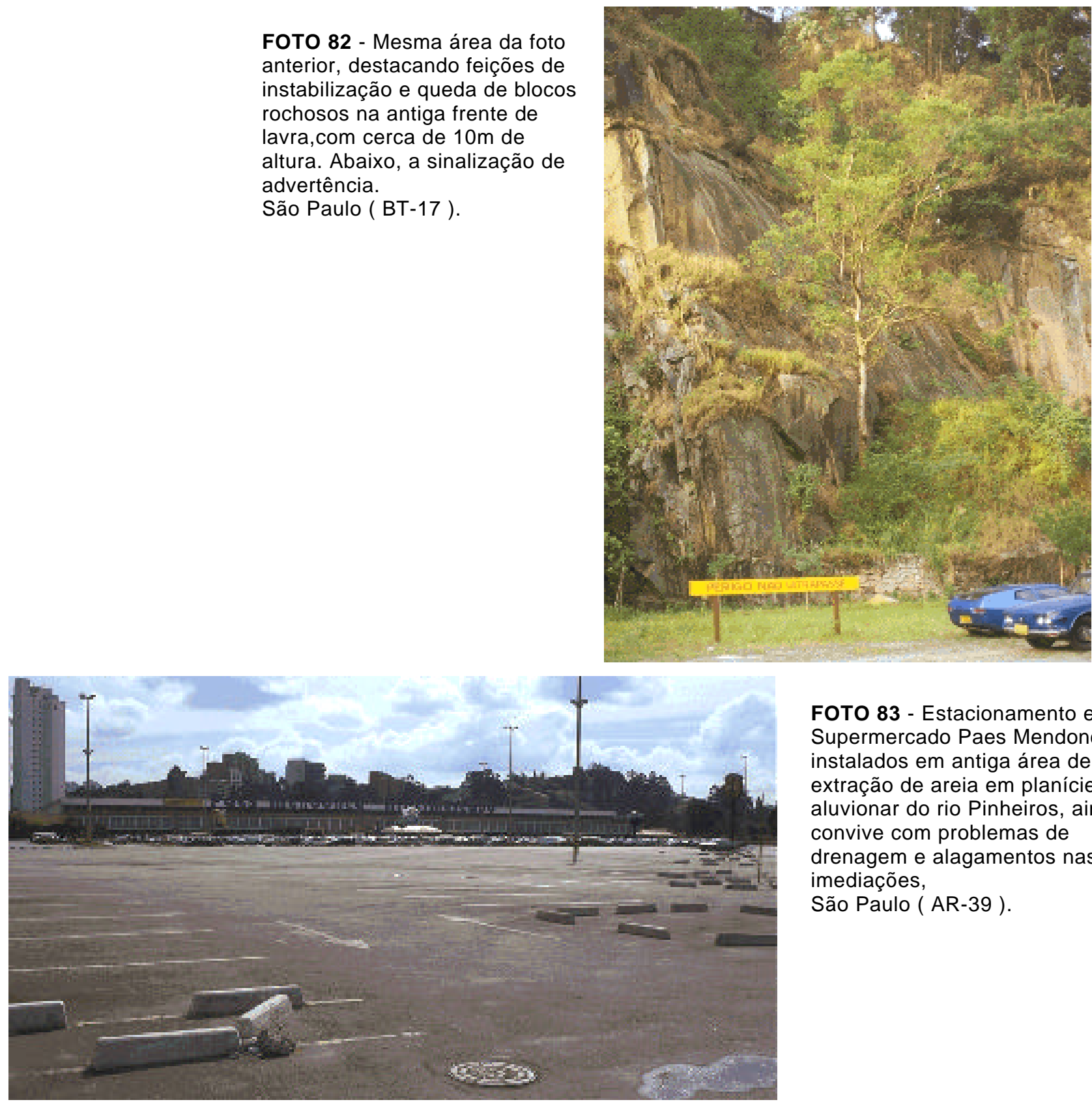

FOTO 83 - Estacionamento e Supermercado Paes Mendonça, instalados em antiga área de extração de areia em planície aluvionar do rio Pinheiros, ainda convive com problemas de drenagem e alagamentos nas imediações,

São Paulo ( AR-39). 


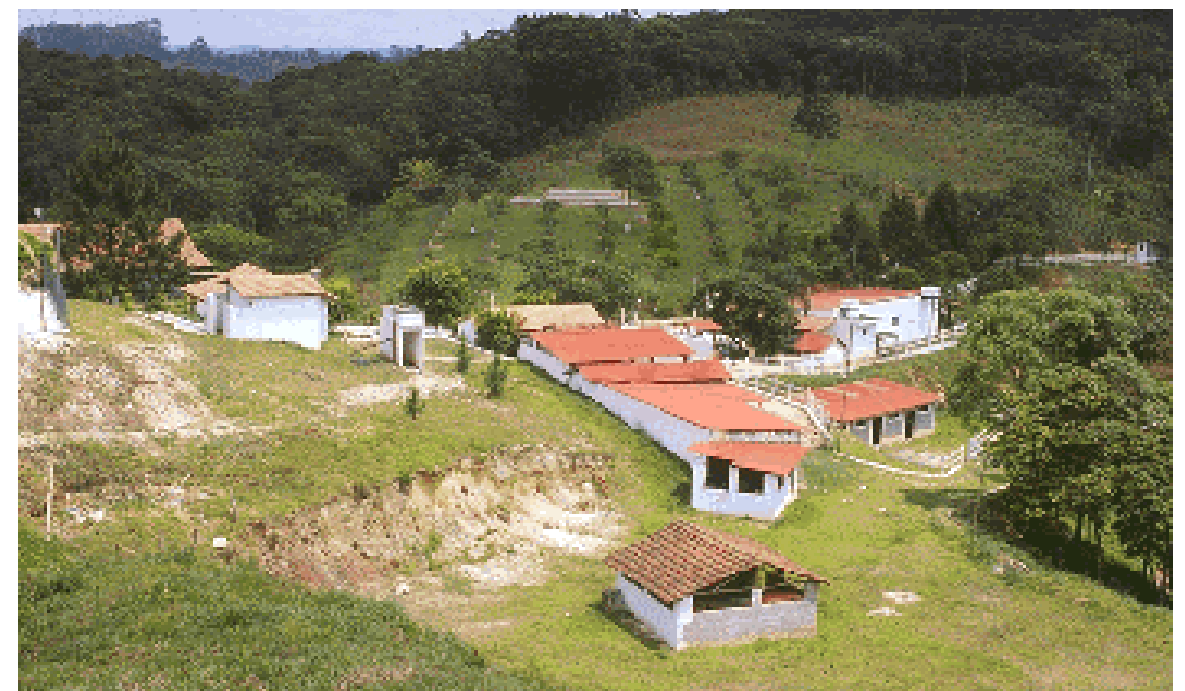

FOTO 84 - Pousada e

churrascaria Serra Verde,

instalada em antiga mineração

de caulim,

São Paulo ( KI-04 ).

FOTO 85 - Mesma área da foto

anterior, destacando o local

próximo àantiga frente de lavra,

São Paulo ( KI-04 ).
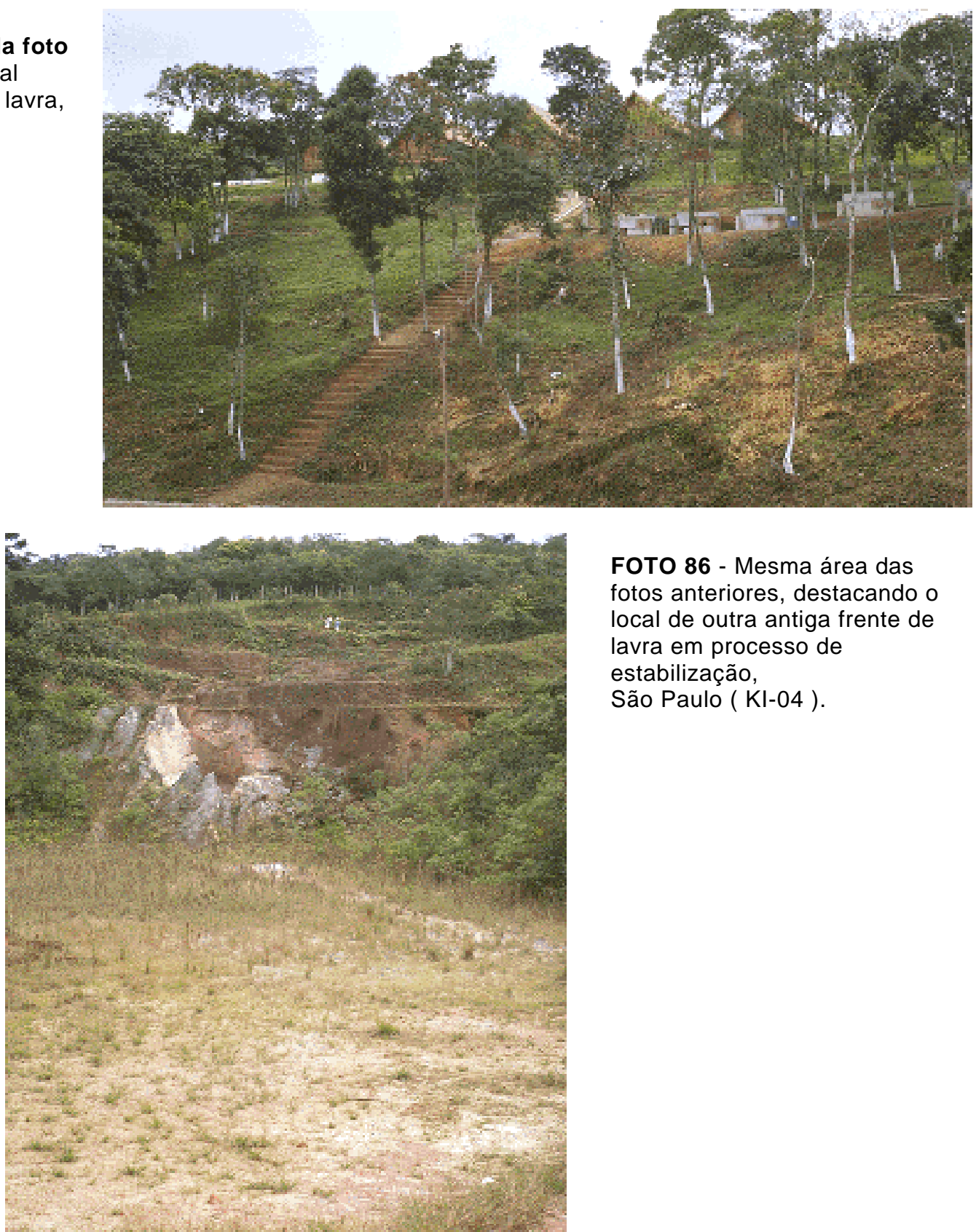

FOTO 86 - Mesma área das

fotos anteriores, destacando o local de outra antiga frente de lavra em processo de

estabilização,

São Paulo ( KI-04 ). 


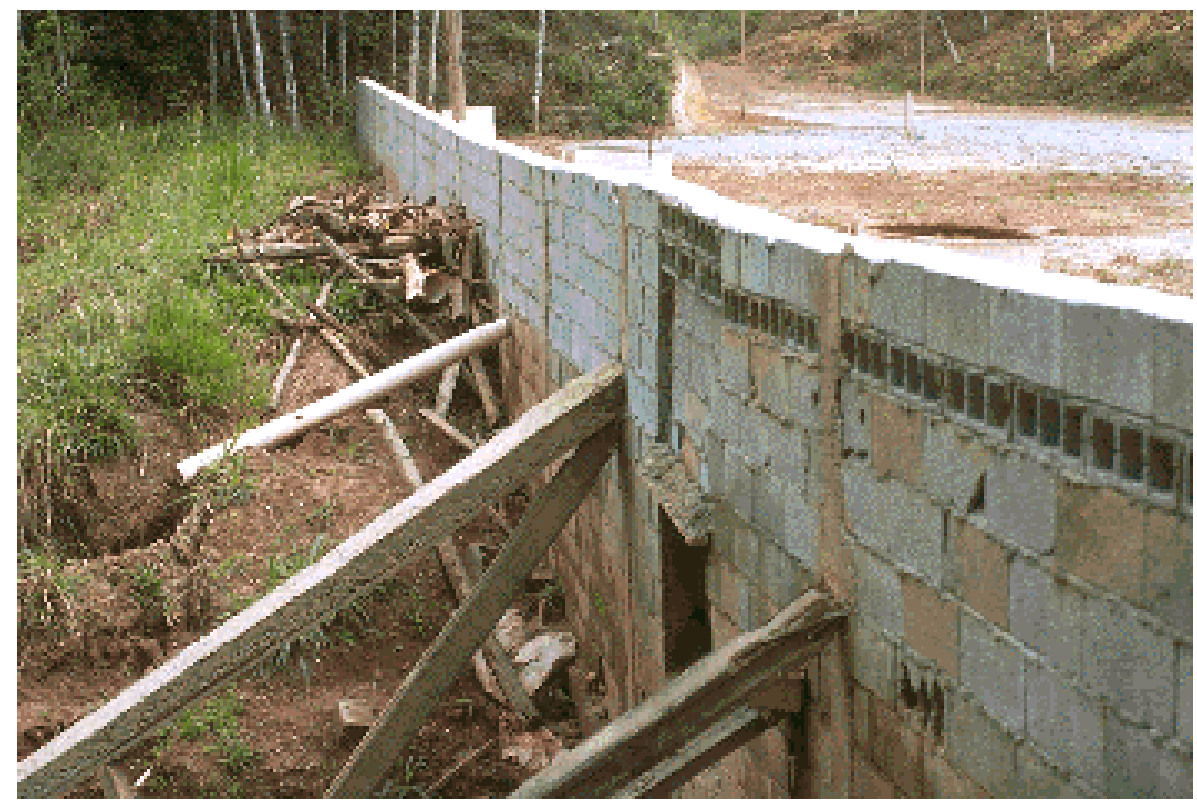

FOTO 87 - Mesma área das

fotos anteriores, exibindo problemas de drenagem e dificuldades na estabilização de obras de contenção de aterro, São Paulo ( KI-04 ).

FOTO 88 - Galpões industriais (ao fundo) instalados em antigas bacias de rejeitos da mineração de areia Sarp. Em primeiro plano, frente de lavra da Pedreira Sarpav, Barueri ( AR-10).
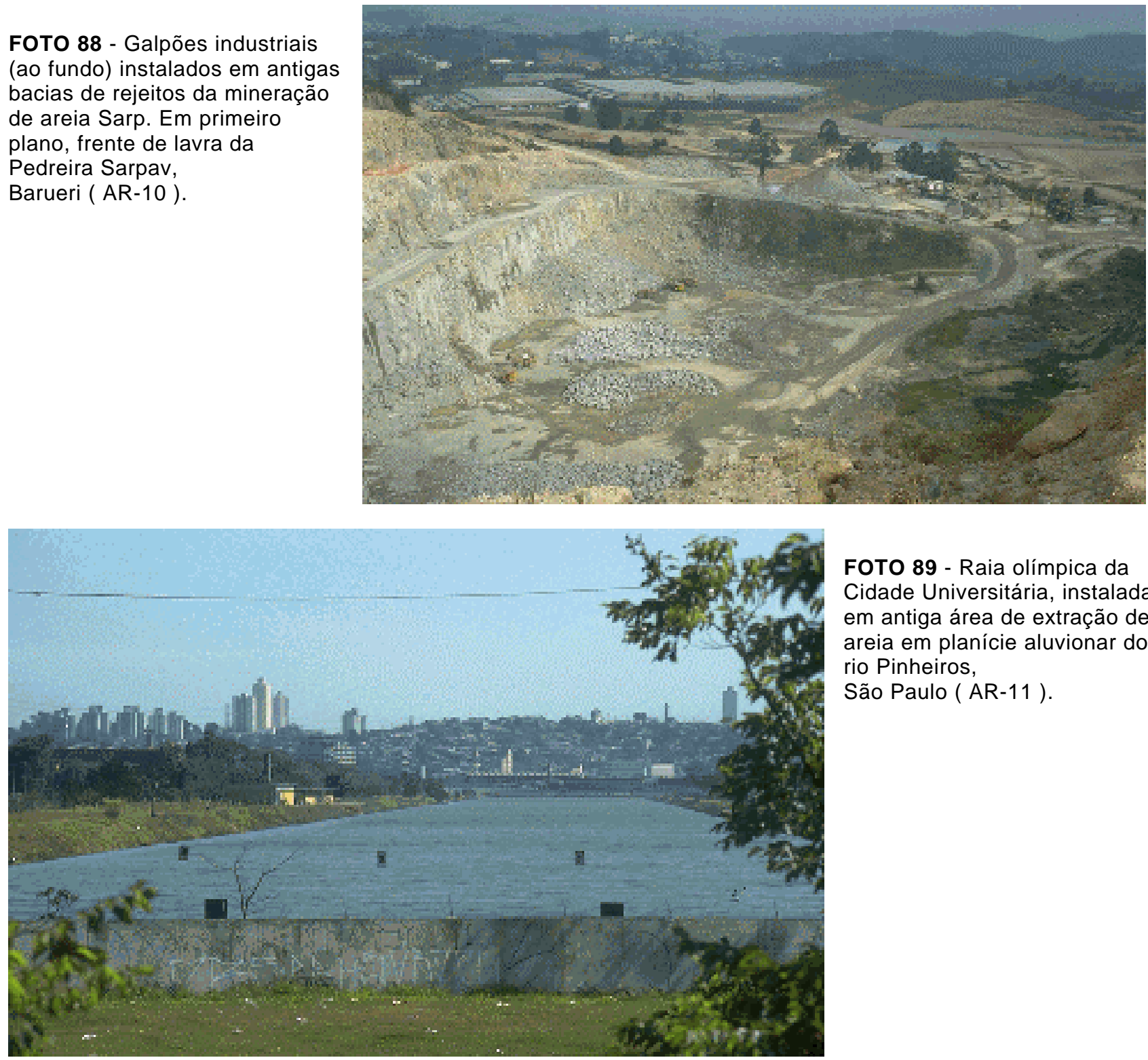

FOTO 89 - Raia olímpica da Cidade Universitária, instalada em antiga área de extração de areia em planície aluvionar do rio Pinheiros, São Paulo ( AR-11). 


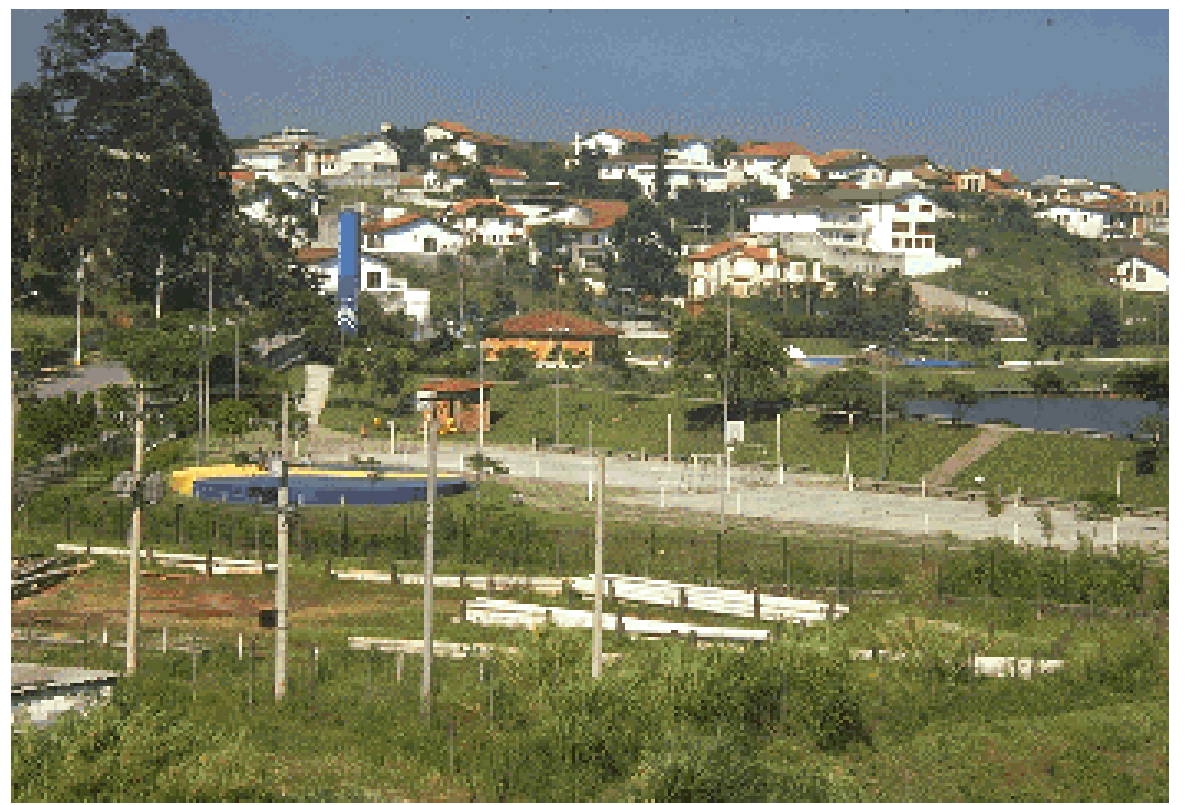

FOTO 90 - Parque Cidade de Toronto, instalado em antiga área de extração de areia, São Paulo ( AR-13).

FOTO 91 - Centro Educacional e Recreativo do Butantã, instalado em área de antiga pedreira, São Paulo ( BT-04 ).
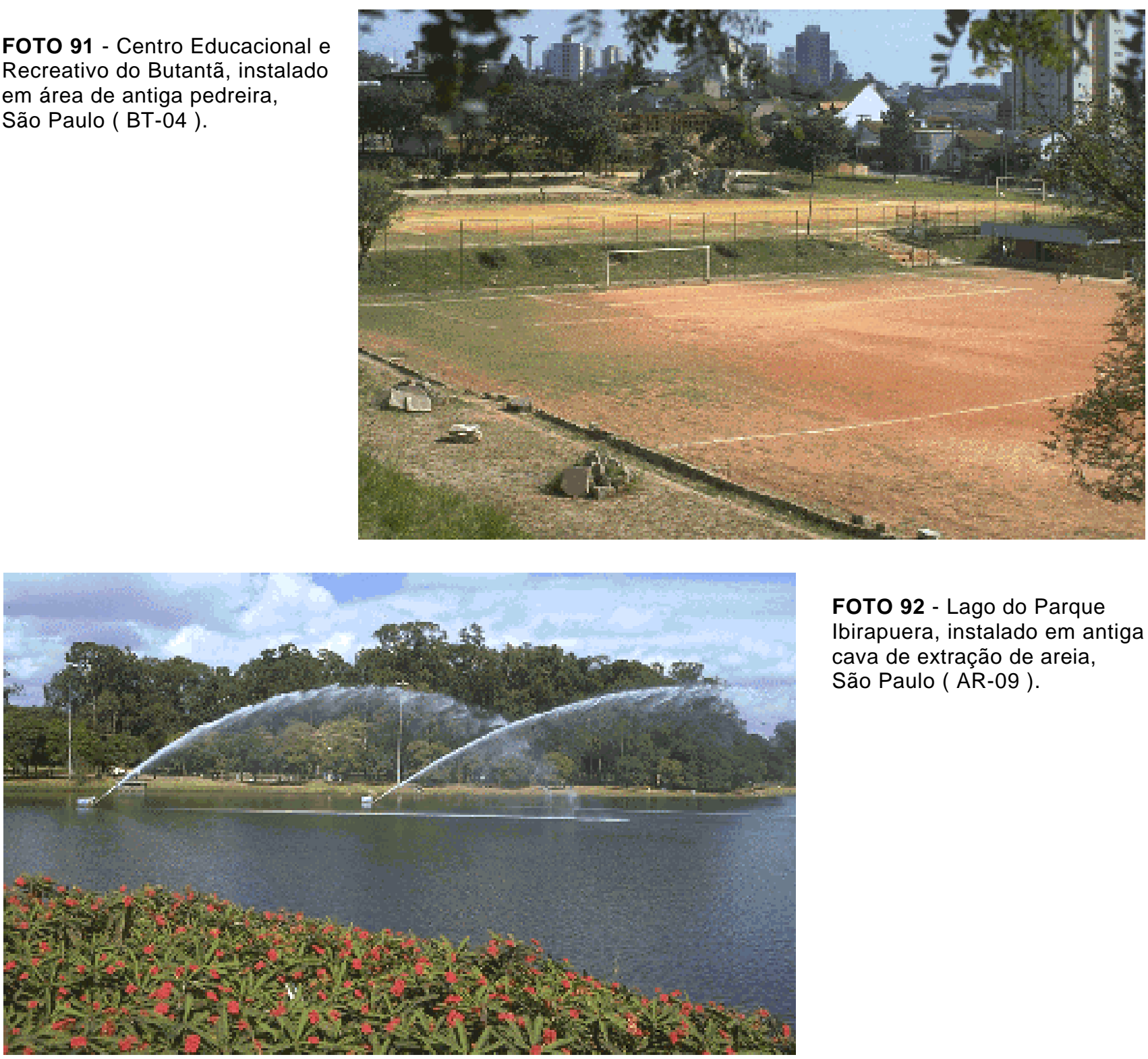

FOTO 92 - Lago do Parque Ibirapuera, instalado em antiga cava de extração de areia, São Paulo ( AR-09 ). 


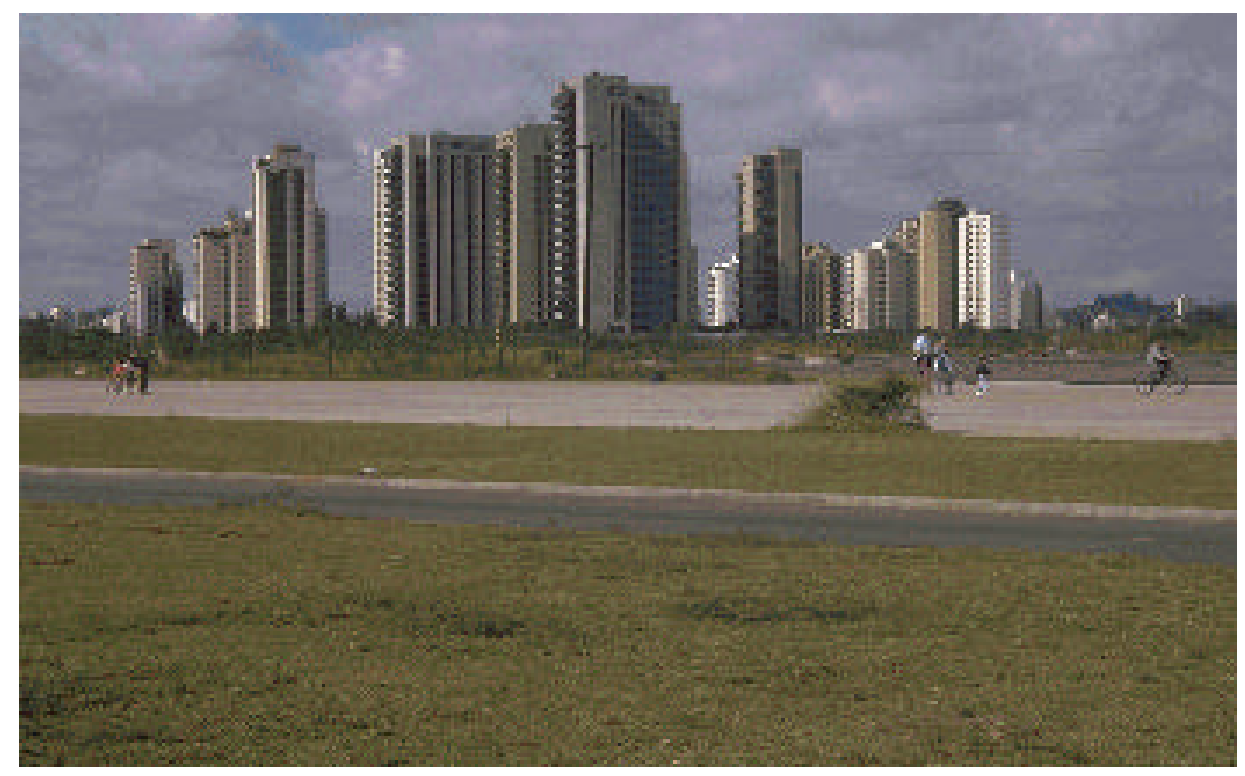

FOTO 93 - As instalações do Parque VillaLobos (em primeiro plano) e conjunto de edifícios (ao fundo), ambos executados em área de antigas extrações de areia em planície aluvionar do rio Pinheiros,

São Paulo ( AR-28 e AR-41).

FOTO 94 - Loteamento habitacional e região comercial em área de antigos portos de areia em planície aluvionar do rio Pinheiros,

São Paulo ( AR-31).
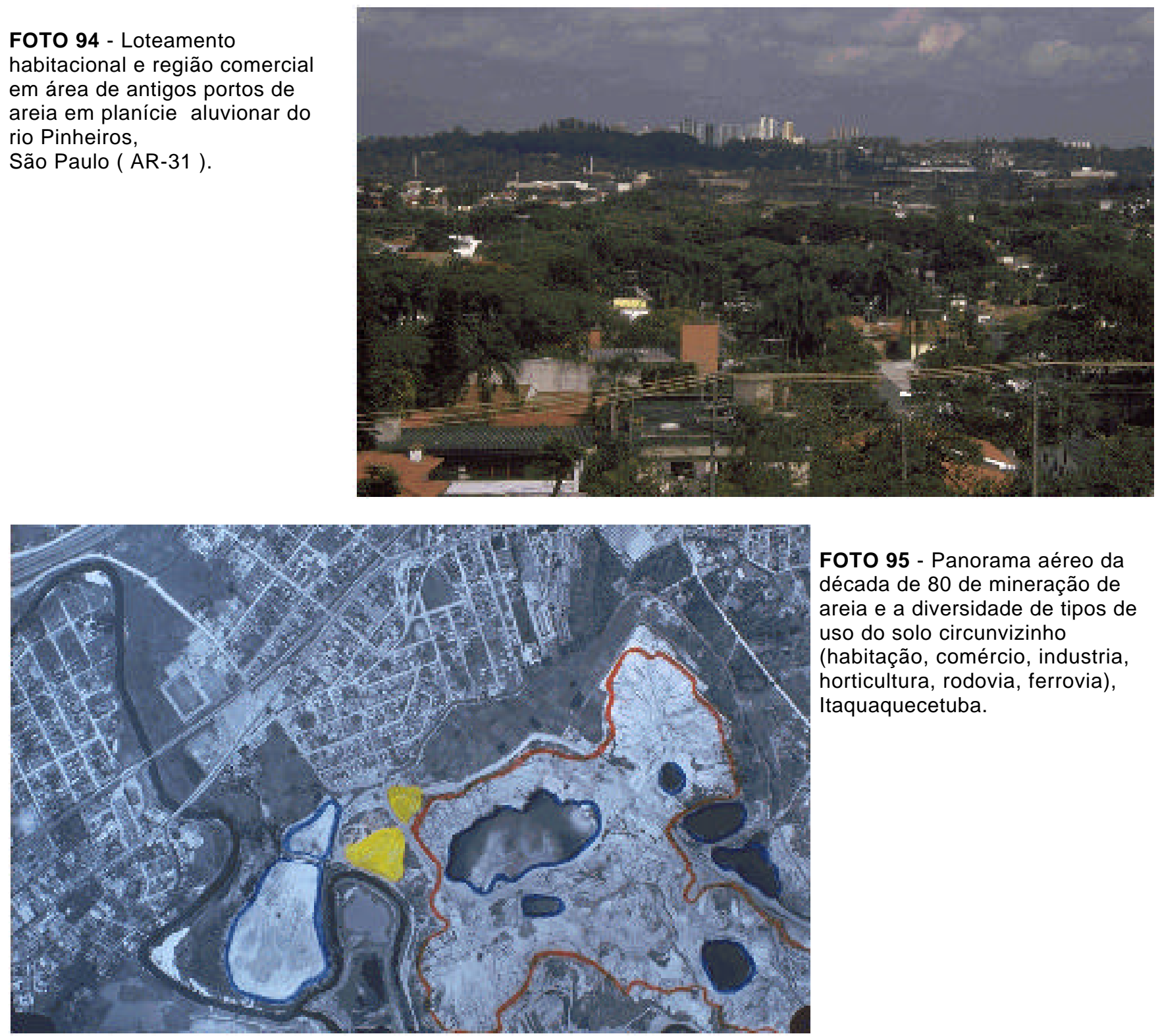

FOTO 95 - Panorama aéreo da década de 80 de mineração de areia e a diversidade de tipos de uso do solo circunvizinho (habitação, comércio, industria, horticultura, rodovia, ferrovia), Itaquaquecetuba. 


\subsubsection{Promotor da reabilitação}

A dimensão dos projetos de reabilitação executados em antigas áreas degradadas por mineração na RMSP, sugere que o dispêndio de recursos financeiros tenha sido significativo na maior parte dos casos. O levantamento de dados não permitiu a obtenção de valores confiáveis sobre os gastos realizados, mas apenas a identificação do tipo de agente patrocinador ou promotor da reabilitação, ou seja, a empresa ou instituição que custeou financeiramente a elaboração do projeto e a instalação do novo uso do solo. A TABELA 6.6 sintetiza as informações sobre os casos levantados.

TABELA 6.6- Áreas reabilitadas $\left(^{*}\right)$, segundo o agente promotor e o bem mineral anteriormente explotado.

\begin{tabular}{|c|c|c|c|c|c|c|c|c|}
\hline & & \multicolumn{4}{|c|}{ Bem mineral explotado } & \multicolumn{3}{|c|}{ Total } \\
\hline \multicolumn{2}{|c|}{ Agente promotor } & Argila & Areia & Brita & Caulim & № & \multicolumn{2}{|c|}{$\%$} \\
\hline \multirow[t]{3}{*}{ Poder Público } & Prefeitura municipal & 02 & 05 & 08 & - & 15 & 37 & \multirow{3}{*}{$4 \varsigma$} \\
\hline & Governo estadual & - & 03 & 01 & - & 04 & 10 & \\
\hline & Governo federal & - & 01 & - & - & 01 & 02 & \\
\hline \multirow[t]{2}{*}{ Empresa privada } & Mineração & - & 02 & - & - & 02 & 05 & \multirow[t]{2}{*}{51} \\
\hline & Outro setor econômico & 06 & 08 & 03 & 02 & 19 & 46 & \\
\hline \multicolumn{2}{|r|}{ Total } & 08 & 19 & 12 & 02 & 41 & \multicolumn{2}{|c|}{100} \\
\hline
\end{tabular}

* reabilitação concluída ou em andamento.

Nota-se o equilíbrio entre os empreendimentos promovidos pelo Poder Público (49\%) e pelas empresas privadas (51\%). No setor público é notável o predomínio das prefeituras municipais, com cerca de $2 / 3$ dos projetos de reabilitação executados com recursos públicos, seguidas pelos governos estadual e federal. Há casos em que o projeto foi executado em parceria, inclusive internacional, como no Parque Cidade de Toronto (AR-13), na cidade de São Paulo, que teria custado cerca de US\$1,5 milhão, dos quais 200 mil doados pela Prefeitura de Toronto, Canadá, com a finalidade de comprar equipamentos de lazer para crianças, sendo o restante custeado pela Prefeitura Municipal de São Paulo.

Entre os agentes promotores, ressalta-se o dado de que as empresas de mineração têm tido uma participação muito pequena $(5 \%)$ em relação ao total de projetos de reabilitação executados na RMSP. Sobre a participação privada de outros setores, pode-se associar o dado 
obtido ao modo pelo qual o espaço urbano tem sido continuamente utilizado na RMSP, ou seja, como resultado do surgimento incessante de novos negócios e conseqüentes efeitos na renovação do uso do solo.

A participação do Poder Público tem ocorrido sobretudo em projetos de lazer, recreação e esportes comunitários e de disposição de resíduos (aterros sanitários). As empresas do setor privado tem participado principalmente em investimentos de projetos industriais, comerciais e de negócios imobiliários (habitação, loteamento), geralmente por meio de organizações de grande porte (TABELA 6.7).

TABELA 6.7- Quantidade de projetos de reabilitação, segundo o tipo de uso do solo e a natureza do promotor.

\begin{tabular}{|c|c|c|}
\hline \multirow{2}{*}{ Uso do solo } & \multicolumn{2}{|c|}{ Projetos de reabilitação (\%) } \\
\hline & Poder Público & Empresa privada \\
\hline Disposição de resíduos & 20 & 04 \\
\hline Indústria, comércio & - & 24 \\
\hline Lazer, recreação e esportes comunitários & 21 & - \\
\hline Habitação, loteamento & 02 & 14 \\
\hline Sistema viário & 04 & - \\
\hline Educação & 02 & 03 \\
\hline Clube recreativo privado & - & 02 \\
\hline Hotelaria & - & 02 \\
\hline Piscicultura & - & 02 \\
\hline & 49 & 51 \\
\hline Total & \multicolumn{2}{|c|}{100} \\
\hline
\end{tabular}




\section{CAPÍTULO 7}

\section{CONCLUSÕES}

Este Capítulo resume as conclusões gerais obtidas a partir da integração e análise dos resultados da pesquisa sobre a recuperação de áreas degradadas por mineração na Região Metropolitana de São Paulo- RMSP, tendo como referência os casos estudados, sendo apresentadas e discutidas em relação àhipótese da pesquisa:

a) o conceito de recuperação de áreas degradadas por mineração tem evoluído ao longo das últimas décadas, passando do objetivo de restabelecer as condições originais do sítio, para a busca de situações em que os impactos ambientais sejam efetivamente corrigidos e que a estabilidade e a sustentabilidade do ambiente sejam asseguradas. A recuperação é crescentemente abordada como um processo que deve ser realizado mediante um plano prévio, visando uma das seguintes alternativas em relação ao uso futuro do solo: alcançar as condições de uso preexistentes àmineração; desenvolver um projeto de uso significativamente diferente do preexistente à mineração; ou simplesmente transformar as áreas degradadas em áreas com condições seguras e estáveis. Assim, a recuperação de áreas degradadas por mineração na RMSP pode ser considerada como um processo que visa a estabilidade em relação ao meio urbano e a progressiva instalação de um uso do solo planejado, em conformidade com as condições ambientais e culturais da circunvizinhança e, ainda, produtivo, gerenciável e potencialmente sustentável;

b) é notável a ausência de uma política pública específica sobre a recuperação de áreas degradadas no País, seja em nível federal, estadual ou metropolitano. A implementação das exigências dispersas na legislação ambiental vigente não conferem ao tema importância ou prioridade para o Poder Público. O evidente esgotamento do modelo de administração centralizada da mineração no País, estabelecido em âmbito federal, repercute sobre a gestão pública do assunto, dado que às dificuldades de articulação em nível estadual e municipal, acrescem-se as que envolvem a União. As tentativas de atuação por meio de convênios não se sustentaram e trouxeram poucos resultados efetivos. Urge descentralizar a gestão para o âmbito estadual, regional e municipal, sobretudo em relação a bens minerais como os que ocorrem na RMSP. Além dos conflitos de competências e da atuação desarticulada dos diferentes órgãos ambientais envolvidos, destacam-se duas ausências nos procedimentos vigentes sobre 
recuperação: participação pública no processo decisório sobre a aprovação do plano de recuperação das áreas degradadas; e mecanismos que assegurem os recursos financeiros necessários à recuperação. A política ambiental vigente não inclui a consulta pública na definição do uso futuro de áreas degradadas por mineração, sendo notável, na prática, a falta de negociação e mediação. Seria necessário uma legislação específica sobre o assunto. Também não há mecanismos institucionais que permitam assegurar recursos financeiros para a execução de projetos de recuperação. Por lei, a recuperação é obrigatória e deve ser executada pelo empreendedor, o que, no entanto, raramente tem ocorrido na RMSP. Para que o Poder Público possa assumir a recuperação nos casos em que o empreendedor abandona a área degradada sem recuperá-la, é necessário estabelecer mecanismos legais que permitam, durante o desenvolvimento da atividade produtiva, a acumulação e reserva de recursos pelas empresas de mineração ou alternativas no campo negocial;

c) a maior parte dos Prads elaborados por empresas de mineração na RMSP e apresentados ao órgão ambiental segue o Roteiro estabelecido pela legislação ambiental estadual a partir de 1989. Entre outras informações solicitadas, os planos de minas ativas contém as possibilidades de usos pós-mineração e as medidas a serem implementadas durante a atividade extrativa. Os planos de minas ativas comumente explicitam dois objetivos fundamentais: a estabilização das áreas degradadas por meio de medidas executadas a curto e médio prazo e o estabelecimento do uso futuro a longo prazo. Nos planos de minas desativadas, as medidas propostas visam alcançar o uso pós-mineração. Em geral, as medidas de recuperação descritas nos Prads expressam uma ampla variedade de possibilidades, destacando-se o domínio de métodos que combinam técnicas de revegetação com procedimentos geotécnicos. Medidas de remediação raramente são propostas. Os tipos de uso do solo previstos nos Prads não se coadunam com o histórico de usos pós-mineração instalados na metrópole, pois a maior parte propõe áreas de lazer enquanto os casos instalados exibem o domínio de áreas para a disposição de resíduos. A maior parte dos planos foi elaborada sem qualquer consulta à comunidade circunvizinha. Os Prads revelam que os objetivos de longo prazo das empresas em relação à recuperação e uso futuro de áreas degradadas não estão bem definidos. Os empreendimentos que apresentam uma definição clara em relação ao uso pós-mineração, correspondem aos que estimam vida útil mais longa. Em geral, os planos de minas ativas não expõem custos e cronogramas de recuperação;

d) as medidas de recuperação praticadas em minas ativas são executadas concomitantemente à atividade extrativa e se destinam principalmente à estabilização 
dos processos de degradação existentes. Todavia, apenas $14 \%$ das minas realizam esses trabalhos em conformidade com o uso pós-mineração previsto em planejamento e expresso em Prad ou documentação técnica correlata. Assim, os procedimentos praticados na maior parte das minas para a instalação de usos pós-mineração, não se correlacionam com os objetivos estabelecidos em planejamento, o que confirma a hipótese da pesquisa;

e) as minas ativas em que são notáveis o progresso e a eficiência na implementação de medidas de recuperação e, às vezes, na realização de experimentos inovadores, geralmente correspondem aos casos em que 0 responsável técnico pelo empreendimento acumula a coordenação dos trabalhos de recuperação, sendo, às vezes, assessorado por profissionais especializados em controle ambiental. No entanto, a atitude gerencial demonstrada nos empreendimentos é reativa em $74 \%$ das minas, particularmente em relação æ̀s exigências dos órgãos ambientais de fiscalização. Medidas implementadas como resultado de atitudes pró-ativas são predominantes em apenas $26 \%$ dos casos. Os custos de recuperação não são contabilizados pelas empresas, assim como os demais gastos com medidas de controle ambiental, sendo incluídos em meio a todas as despesas operacionais realizadas rotineiramente nos empreendimentos. Nenhum dos empreendimentos apresenta um sistema de gerenciamento ambiental implementado, embora algumas minas possam evoluir rapidamente para isto;

f) há uma evidente dissociação entre as medidas praticadas e aquelas preconizadas nos planos de recuperação elaborados pelas empresas de mineração. Confirma-se a hipótese da pesquisa quanto à evidência de que a maior parte dos trabalhos de recuperação de áreas degradadas praticados em minas ativas na RMSP tem caráter incipiente e se baseia principalmente na execução de medidas restritas de revegetação, visando, em especial, atenuar o impacto visual gerado. Isto é denotado sobretudo pelas medidas disseminadas (instalação de barreiras vegetais; arborização dispersa na área da mineração; remodelamento topográfico; retaludamento e revegetação de áreas lavradas; e revegetação de taludes de barragens de rejeito), cujo desempenho é predominantemente regular a insatisfatório. Não obstante, estas medidas podem alcançar um desempenho satisfatório no futuro. As medidas emergentes (remoção, estocagem e utilização da camada orgânica do solo superficial; remoção, estocagem e utilização da camada argilosa do solo superficial; remoção dirigida de estéreis e prenchimento de cavas; instalação de sistemas de drenagem em barragens de rejeito; reforço e revegetação em barragens de rejeito; instalação de extravasores em barragens 
de rejeito; transposição de rejeitos de bacias de decantação para áreas lavradas; instalação de sistemas de drenagem e retenção de sedimentos; construção e estabilização de bota-foras; retenção de óleos e graxas; revegetação de taludes em acessos e vias internas; remoção de blocos rochosos instáveis em áreas lavradas; abatimento e revegetação de taludes marginais em lagos remanescentes; proteção e manejo da vegetação remanescente; indução e manejo da revegetação espontânea) também apresentam caráter incipiente, embora com finalidades diversificadas e com algumas inovações. O desempenho destas ainda é regular a insatisfatório. As medidas experimentais (revegetação em bermas e taludes rochosos; e revegetação em solos de alteração de rochas) também exprimem o caráter incipiente e fundamentado em revegetação, embora, neste caso, indiquem o empenho na inovação técnica. Em síntese, é necessário melhorar a qualidade das práticas atuais em minas ativas, estimulando a inovação tecnológica e assegurando a difusão e transferência das técnicas desenvolvidas;

g) as minas desativadas têm favorecido a ocupação desordenada. A degradação existente compreende: antigas minerações de areia ou de caulim, em que ocorrem processos intensos de degradação; áreas remanescentes de antigas pedreiras, em que se observa relativa estabilidade; e áreas que foram objeto de extração de areia e/ou de argila aluvionares, cujas cavas remanescentes, total ou parcialmente inundadas, encontram-se permanentemente sujeitas à deposição desordenada de resíduos. Exceto nos casos de pedreiras antigas, as áreas de minas desativadas estão sob processos de degradação importantes. A recuperação e o estabelecimento de usos pós-mineração nessas áreas certamente exigirão o dispêndio de recursos financeiros significativos;

h) as antigas áreas de mineração hoje ocupadas por outros usos do solo compreendem duas situações distintas: áreas em que a ocupação ocorre de forma desordenada; e áreas em que se implementa um projeto planejado de uso do solo. A ocupação desordenada ocorre em $24 \%$ dos casos e se caracteriza pela ausência de um plano prévio, revelando modalidades de uso do solo cujas possibilidades de gerenciamento e sustentabilidade são extremamente incertas. Os tipos de uso atual do solo freqüentes nessas áreas são os depósitos de resíduos e as habitações de baixa renda, o que confirma a hipótese da pesquisa. A estabilização e reabilitação dessas áreas, com a remediação de áreas contaminadas e subseqüente reurbanização, certamente exigirão recursos financeiros significativos. Os projetos de recuperação planejada compreendem $76 \%$ dos casos, sendo predominantes os de disposição de resíduos. No entanto, apesar da perspectiva de reabilitação preconizada, a instalação planejada de um uso pós- 
mineração nem sempre tem resultado no encerramento da degradação. Algumas áreas abrigam usos que têm exigido medidas de estabilização contínuas e onerosas. Boa parte dos projetos de reabilitação ainda convivem com problemas de estabilidade. Alguns destes projetos foram realizados sem investigação do passivo ambiental e sem uma análise do cenário de funcionamento futuro do novo uso. Destacam-se os casos de pedreiras destinadas à instalação de aterros sanitários e que têm requerido obras visando assegurar a estabilidade da massa de lixo. Os projetos de áreas de lazer, recreação, esportes comunitários, construções habitacionais e loteamentos tendem a propiciar situações mais favoráveis tanto àgerenciabilidade quanto àsustentabilidade;

i) no que se refere ao agente promotor da reabilitação, ou seja, a entidade que tem custeado financeiramente a elaboração do projeto e a instalação do novo uso do solo, nota-se o equilíbrio entre os empreendimentos promovidos pelo Poder Público (49\%) e pelas empresas privadas $(51 \%)$, dado que não confirma uma das evidências que fundamentaram a hipótese da pesquisa. No setor público o predomínio é das prefeituras municipais, especialmente em projetos de disposição de resíduos. No setor privado os investimentos prevalecem em projetos industriais, comerciais e imobiliários. Ressalta-se o fato de que as empresas de mineração têm tido uma participação muito pequena (5\%) em relação ao total de projetos de reabilitação implementados. 


\section{REFERÊNCIAS BIBLIOGRÁFICAS}

ABREU, S.F. Recursos minerais do Brasil. 2.ed. Rio de Janeiro: Edgard Blücher/Edusp, 1973. $2 \mathrm{v}$.

AB'SABER, A.N.. Súmula geomorfológica do Planalto Paulistano. In: MESA REDONDA SOBRE ASPECTOS GEOLÓGICOS E GEOTÉCNICOS DA BACIA SEDIMENTAR DE SÃO PAULO, 1980, São Paulo. Anais... São Paulo: ABGE/SBG-SP, 1980. p.33-36.

ALBA, D. Exploitation: impact et paysages. Alés: École Nationale Superieure des Tecniques Industrielles et des Mines d’Álés, 1995. v.1. (Notas de aula de pós-graduação).

ALEXANDRIA, A.L. .A atividade minerária e a relação com a sociedade. In: ENCONTRO DE MINERAÇÃO NO MUNICÍPIO DE SÃO PAULO, 1, 1984, São Paulo. Anais... São Paulo: SAR/PMSP/Epusp, 1995. v.1, p.95-99.

ALMEIDA, C.M., BRUNA, G.C. Conceitos de preservação, recuperação, renovação, reabilitação e revitalização ambiental urbana: principais exemplos e técnicas utilizadas. São Paulo: FAU/FSP-USP, 1996. (Roteiro geral de disciplina sobre gestão de áreas especiais).

ALMEIDA, A.S., FORNASARI FILHO, N., BRAGA, T.O., SILVA, W.S. , PAMPLONA, R.I. Controle e recuperação ambiental na Mina de Cana Brava - Goiás. São Paulo: Sama/IPT. 68 p. (IPT. Boletim, 66. Publicação 2006).

AMARAL, R. Zona sul vira a "Grande Morumbi". Folha de São Paulo, São Paulo, 24 mar. 1996. p. 1, c. 7.

ANDERSON, K. Using financial assurances to manage the environmental risks of mining projects. In: SEMINAR ON CAPACITY BUILDING FOR ENVIRONMENTAL MANAGEMENT IN ASIAN/PACIFIC MINING, 1994, Jakarta. Proceedings... Jakarta: UNCTAD, 1994. p.62-72.

ARChANGeletti, A.C., TAKAHASHI, E., BARNABÉ, H.R., PIZA FILHO, P.T., HONDA, S. Projeto: Parque Cidade de Toronto. In: PHILLIPI JR., A., coord. A questão ambiental urbana: cidade de São Paulo. São Paulo: PMSP/SVMA, 1993, p.573-587.

ARNOULD, M. Estudo do impacto da mineração de agregados sobre o meio ambiente na França: legislação, reabilitação de áreas, balanço de 10 anos de experiência. In: SEMINÁRIO INTERNACIONAL SOBRE MINERAÇÃO EM ÁREAS URBANAS, 1, 1989, São Paulo. Anais... São Paulo: DNPM/Pró-minério, 1989. p.21-24.

ASSOCIAÇÃO BRASILEIRA DE NORMAS TÉCNICAS. Degradação do solo- terminologia- NBR 10.703. Rio de Janeiro: ABNT, 1989.

Coletânea de normas de mineração e meio ambiente. Rio de Janeiro: ABNT/CVRD, 1993. 58 p.

AUGUSTO FILHO, O., BITAR, O.Y., SOUZA, L.A.P., ALMEIDA, M.C.J. Análise e zoneamento de risco associado à mineração em área urbana: o caso da extração de areia no lago de Carapicuíba. In: CONGRESSO BRASILEIRO DE GEOLOGIA, 37, 1992, São Paulo. Boletim de resumos expandidos... São Paulo: SBG, 1992. v.1, p.116-117.

AUSTRÁLIA. Environmental Protection Agency. Rehabilitation and revegetation. Australia: EPA, 1995. 36 p. (Serie on Best Practice Environmental Management in Mining). 
AZIZ, M.N.B.A. Environmental policies for the mining industry in Malaysia. In: SEMINAR ON CAPACITY BUILDING FOR ENVIRONMENTAL MANAGEMENT IN ASIAN/PACIFIC MINING, 1994, Jakarta. Proceedings... Jakarta: UNCTAD, 1994. p.47-52.

BARTH, R.C. Avaliação da reabilitação de áreas mineradas no Brasil. Brasil Mineral, p.60-72, out. 1989. (Edição especial: meio ambiente).

BAUER, A.M. A guide to site development and rehabilitation of pits and quarries. Toronto: Ontario Department of Mines, 1970. 62 p.

Mineração planejada e reabilitação de áreas. In: SEMINÁRIO INTERNACIONAL SOBRE MINERAÇÃO EM ÁREAS URBANAS, 1, 1989, São Paulo. Anais... São Paulo: DNPM/Pró-minério, 1989a. p. 31-35.

Uso futuro de áreas mineradas. In: SEMINÁRIO INTERNACIONAL SOBRE MINERAÇÃO EM ÁREAS URBANAS, 1989, São Paulo. Anais... São Paulo: DNPM/Próminério, 1989b. p.25-30.

BAXTER, J.G. Site planning for sand and gravel operations. Silver Spring: University of Illinois/National Sand and Gravel Association, 1969. (Project, n. 4).

BITAR, O.Y. Mineração e usos do solo no litoral paulista: estudo sobre conflitos, alterações ambientais e riscos. Campinas, 1990. 162 p. Dissertação (Mestrado)- Instituto de Geociências, Universidade Estadual de Campinas.

- Recuperação de áreas mineradas: considerações sobre técnicas aplicáveis a regiões urbanas. In: WORKSHOP INTERNATIONAL SOBRE TECNOLOGIA E DESENVOLVIMENTO SUSTENTÁVEL, 1, São Paulo, 1992. São Paulo: Cetesb/SMA/SPECO-92, 1992. 8 p. (Separata).

BITAR, O.Y., FORNASARI FILHO, N., VASCONCELOS, M.M.T., SILVA, W.S. A abordagem do meio físico nos estudos de recuperação ambiental de áreas de mineração de areia na Região Metropolitana de São Paulo - RMSP. In: CONGRESSO BRASILEIRO DE GEOLOGIA DE ENGENHARIA, 6, 1990, Salvador. Anais... Salvador: ABGE, 1990. v.1, p.251-259.

BITAR, O.Y., FORNASARI FILHO, N., BRAGA, T.O., ALMEIDA, A.S., SILVA, W.S. Diretrizes para reabilitação de áreas mineradas em regiões urbanas. In: CONGRESSO BRASILEIRO DE GEOLOGIA, 37, 1992, São Paulo. Boletim de resumos expandidos... São Paulo: SBG, 1992. v. 1, p.36-37.

BITAR, O.Y., AUGUSTO FILHO, O., IWASA, O.Y.; CUNHA, M.A.; FORNASARI FILHO, N. Indicadores geológico-geotécnicos na recuperação ambiental de áreas degradadas em regiões urbanas. In: CONGRESSO BRASILEIRO DE GEOLOGIA DE ENGENHARIA, 7, 1993, Poços de Caldas. Anais... Poços de Caldas: ABGE, 1993a. v. 2, p.177-183.

BITAR, O.Y., BRAGA, T.O., PARZZANESE, G.A.C.; OKAGAWA, H. The planned used of mining areas to waste disposal: a challenge to the brazilian metropolis. In: INTERNATIONAL SEMINAR ON THE ENVIRONMENTAL PROBLEMS OF URBAN CENTERS-ECO URBS'S 93, 2, 1993, São Paulo. Abstracts... São Paulo: Biosfera, 1993b. p.121-122. 
BITAR, O.Y., BRAGA, T.O. O meio físico na recuperação de áreas degradadas. In: BITAR, O.Y., coord.. Curso de geologia aplicada ao meio ambiente. São Paulo: ABGE/IPT-Digeo, 1995. p.165-179. (Série Meio Ambiente).

BLAIKIE, P. Explanation and policy in land degradation and rehabilitation for developing countries. Land Degradation \& Rehabilitation, London, v. 1, n. 1, p.23-37, Jul./Aug, 1989.

BOX,T.W. Reclamation of drastically disturbed land. In: SYMPOSIUM OHIO, 1, 1978, Wooster. Proceedings... Wisconsin: American Society of Agronomy, 1978. p.3-5.

BRAGA, T.O., FORNASARI FILHO, N., BATISTUCCI, S.G.G., MONTANHESI, M.O.R., COSTA, V.L.C., ALUANI, S.S., PAMPLONA, R.I. Auditoria ambiental: uma proposta para empreendimentos mineiros. São Paulo: IPT/Sama, 1996. 118 p. (IPT. Publicação, 2451).

BRAGA, T.O., FORNASARI FILHO, N., OKAGAWA, H., AUGUSTO FILHO, O. Recuperação ambiental de áreas degradadas pela extração de material de empréstimo (solo de alteração de rocha): estudo de dois casos no município de Iguape, SP. In: CONGRESSO BRASILEIRO DE GEOLOGIA, 39, 1996, Salvador. Anais... Salvador: SBG-BA, 1996. v.4. p. 366-371.

BRASIL MINERAL. Mineração e meio ambiente. São Paulo, out. 1989. (Edição especial: meio ambiente).

BROUGHTON, L.M., HEALEY, P.M. MIne site decommissioning: technology for assessment and control of acid rock drainage. In: INTERNACIONAL CONFERENCE ON ENVIRONMENT ISSUES AND MANAGEMENT OF WASTE IN ENERGY AND MINERAL PRODUCTION, 2, 1992, Calgary. Proceedings... Calgary: FGC/UL/UC, 1992. p.789-798.

CAIRNS JR., J. Restoration, reclamation and regeneration of degraded or destroyed ecosystems. In: SOULÉ, M.E., org. Conservation biology. Sunderland: Sinauer, 1986. p. 465-484.

CANADÁ. Ministry of Northern Development and Mines. Mines and Minerals Division. $A$ summary of the mining act of Ontário-RSO/RRO, 1990.Ontário, 1990. Part 9, 6 p.

CARCEDO, F.J.A., FERNANDEZ, L.V. Manual de restauracion de terrenos y evaluacion de impactos ambientales en mineria. Madrid: ITGE/MTE, 1989. 321 p. (Série Ingenería Geoambiental).

CARRIDO, F. Gestão pública: o próximo desafio. O BID, p.3, nov. 1996.

CARTER, R.A. Landfills can be profitable. Rock Products, Chicago, v. 92, n. 12, p.58-62, Dec. 1989a. 74, Oct. $1989 b$.

Reclamation: a regulatory view. Rock Products, Chicago, v. 92, n. 10, p.58-63, Planning for second uses. Rock Products, Chicago, v. 93, n. 1, p.66-71, Jan. 1990a. Reclamation grows overseas. Rock Products, Chicago, v. 93, n. 2, p.40-44, Feb. 1990b. 
CASSIANO, A.M., CAVALCANTI, R.N. A importância do gerenciamento ambiental na empresa de mineração de ouro: estudo comparativo de 2 empresas atuantes no Brasil. In: CONGRESSO BRASILEIRO DE GEOLOGIA, 39, 1996, Salvador. Anais... Salvador: SBGBA, 1996. v. 4, p.7-10.

CAVALCANTI, R.N. A mineração e o desenvolvimento sustentável: casos da Companhia Vale do Rio Doce. São Paulo, 1996. 432p. Tese (Doutorado) - Escola Politécnica, Universidade de São Paulo.

CENTRO DE ESTUDOS E PESQUISAS DE ADMINISTRAÇÃO MUNICIPAL. Política municipal de meio ambiente. São Paulo: Cepam, 1991. 172 p.

CHAVES, A. P. Teoria e prática do tratamento de minérios. São Paulo: Signus, 1996. 2v.

CHIOSSI, N., CASADEI, D.S., MAGLIO, I.C., FREIRE, J.A.M., FONTES, POLETTO, C., FRISCHENBRUDER, M.M., BASSOLI, M. A degradação ambiental provocada pela exploração mineral na Região Metropolitana de São Paulo, Brasil: diagnóstico, propostas e medidas para seu controle e prevenção. In: CONGRESSO LATINOAMERICANO DE GEOLOGIA, 5, 1982, Buenos Aires. Actas... Buenos Aires, 1982. v. 3, p.207-226.

CHISHOLM, A.; DUMSDAY, R. Land degradation: problems and policies. London: John Wiley, 1987. $404 \mathrm{p}$.

CLARK, I. Using financial assurances to manage the environmental risks of mining projects. In: SEMINAR ON CAPACITY BUILDING FOR ENVIRONMENTAL MANAGEMENT IN ASIAN/PACIFIC MINING, 1994. Jakarta. Proceedings... Jakarta: UNCTAD, 1994. p.56-61.

COLLAÇO, D.L., SILVEIRA, A.S. DA, FAUTH, G. Programa de desativação da mineração de arenito Botucatu, no Morro de Paula, em São Leopoldo- RS. In: SIMPÓSIO SULBRASILEIRO DE GEOLOGIA, 6, 1995. Porto Alegre. Anais... Porto Alegre: SBG-RS, 1995. p.363-365.

COMISSÃO DE DESENVOLVIMENTO E MEIO AMBIENTE DA AMÉRICA LATINA E CARIBE. Nossa própria agenda. Rio de Janeiro: BID/PNUD, 1990. 241 p.

COMPANHIA DE PESQUISA DE RECURSOS MINERAIS. Projeto seleção de áreas para a mineração de areia na Região Metropolitana de São Paulo- RMSP. São Paulo: SuregSP/Próminério, 1986. 31p. (CPRM. Relatório final).

COMPTON, H. Field screening methods. In: RCRA CORRECTIVE ACTION STABILIZATION TECHNOLOGIES, 1992, Washington. Proceedings... Cincinnati: USEPA, 1992. p. 21-28.

COMUNE, A.E. Contabilização econômica do meio ambiente: uma visão geral. In: SECRETARIA DO MEIO AMBIENTE. Contabilização econômica do meio ambiente: elementos metodológicos e ensaio de aplicação no Estado de São Paulo. São Paulo: SMA, 1992. p.13-27. (Série Seminários e Debates).

COPPIN, N.J.; BRADSHAW, A.D. Quarry reclamation: the establishment of vegetation in quarries and open pit non-metal mines. London: Mining Journal Books, 1982. 112 p.

COUTINHO, J.M.V. Carta geológica da região metropolitana da Grande São Paulo: escala 1:100.000. São Paulo: EMPLASA, 1980. 
DEPARTAMENTO NACIONAL DA PRODUÇÃO MINERAL. Companhia de Desenvolvimento da Região Metropolitana de Salvador. Superintendência de Geologia e Recursos Minerais da Bahia. Plano Diretor de mineração para a Região Metropolitana de Salvador. Salvador: DNPM, 1992. 124 p.

DIETRICH, N.L. European rehabilitation projects reflect cultural and regional diversity. Rock Rroducts, Chicago, v.93, n.2, p.45-47, Feb. 1990.

DHAR, B.B. Environmental impact assessment for mining: the Indian scenario. In: SEMINAR ON CAPACITY BUILDING FOR ENVIRONMENTAL MANAGEMENT IN ASIAN/PACIFIC MINING, 1994. Jakarta. Proceedings... Jakarta: UNCTAD, 1994. p.36-37.

DOWN, C.G., STOCKS, J. Environmental impact of mining. New York: John Wiley, 1977. 371 p.

EMPRESA METROPOLITANA DE PLANEJAMENTO DA GRANDE SÃO PAULO. $A$ mineração $e$ o planejamento metropolitano. São Paulo: SHDU/Emplasa, 1989a. 6 p.

Implantação do Plano Diretor de Mineração para a RMSP - Fase 7. São Paulo: SNM/Emplasa, 1989b. 69 p.

Plano Metropolitano da Grande São Paulo 1993/2010. São Paulo: Emplasa, 1994. 256 p.

ESTADOS UNIDOS DA AMÉRICA. Environmental Protection Agency. Handbook on in situ treatment of hazardous waste - contamined soils. Cincinatti: EPA, 1990. 157 p. (EPA/540/290/002).

FORNASARI FILHO, N. Alterações nos processos do meio físico por mineração: estudo de caso de instrumentos de gerenciamento ambiental. São Paulo, 1995. 101 p. Dissertação (Mestrado) - Ciência Ambiental, Universidade de São Paulo.

FORNASARI FILHO, N., NAKASU, L., PRANDINI F.L., GODOY, F.R. Experimentos de revegetação destinados ao controle de erosão em corpos de bota-fora da Mina de Cana Brava, GO. In: CONGRESSO BRASILEIRO DE GEOLOGIA, 34, 1986, Goiânia. Anais... Goiânia: SBG, 1986. v.1, p.494-499.

FREITAS, M. de L.D. de, PORTO, E.R., BENEDETTI, V. Estudo de recuperação de áreas degradadas pela mineração de ferro: a experiência em Carajás. In: CONGRESSO DE TRÓPICO ÚMIDO, 1, 1984. Belém. Anais...Belém, 1984.

FUJIMURA, F., RICCIARDI, C.T.R., NOGUEIRA JUNIOR, J.; ERTHAL, F.L.C. Parque produtor de britas: uma solução integrada para pedreiras da Região Metropolitana do Rio de Janeiro. In: CONGRESSO BRASILEIRO DE GEOLOGIA DE ENGENHARIA, 4, 1984. Belo Horizonte. Anais... Belo Horizonte: ABGE, 1984. v. 1, p.84-93.

GRIFFITH, J.J. O estado da arte na recuperação de áreas mineradas no Brasil. In: SIMPÓSIO NACIONAL SOBRE RECUPERAÇÃO DE ÁREAS DEGRADADAS, 1, 1992, Curitiba. Anais... Curitiba: Fupef, 1992. p.77-82.

GRIFFITH, J.J., DIAS, L.E., JUCKSCH, I. Novas estratégias ecológicas para a revegetação de áreas mineradas no Brasil. In: SIMPÓSIO NACIONAL SOBRE RECUPERAÇÃO DE ÁREAS DEGRADADAS, 2, 1994, Foz do Iguaçu. Anais... Curitiba: Fupef, 1994. p.31-43. 
GRIFFITH, J.J., DIAS, L.E., JUCKSCH, I. Recuperação de áreas degradadas usando vegetação nativa. Saneamento Ambiental, São Paulo, v.7, n. 37, p.28-37, fev./mar. 1996.

HERMANN, H. Política de aproveitamento de areia no Estado de São Paulo: dos conflitos existentes às compatibilizações possíveis. Rio de Janeiro: Cetem/CNPq, 1992. 186 p. (Série Estudos e Documentos, 18).

HOLMBERG, G.V., HENNING, S.J. Reclamation. In: SENDLEIN, V.A., YAZICIGIL, H, CARLSON, C.L. eds., Surface mining environmental monitoring and reclamation handbook. New York: Elsevier, 1983. Cap. 3, p.279-396.

IBRAHIM, M.M.C. Utilização de áreas degradadas pela mineração: o caso da Pedreira Itaquera, São Paulo, SP. São Paulo, 1996. 183p. Dissertação (Mestrado) - Escola Politécnica, Universidade de São Paulo.

INSTITUTO BRASILEIRO DE GEOGRAFIA E ESTATÍSTICA. Anuário estatístico do Brasil. Rio de Janeiro: Fundação IBGE, 1994. v. 54, p.1.1-8.32.

INSTITUTO BRASILEIRO DE MINERAÇÃO. Comissão Técnica de Meio Ambiente. Grupo de Trabalho de Redação. Mineração e meio ambiente. Brasília: Ibram, 1992. 114 p.

INSTITUTO DE PESQUISAS TECNOLóGICAS DO ESTADO DE SÃO PAULO. Subsídios para o planejamento do uso do solo urbano, para a recuperação de habitações subnormais e áreas degradadas na Grande São Paulo- Carta geotécnica da Região Metropolitana de São Paulo; escala 1:50.000. São Paulo, 1985 (IPT. Relatório, 19.817).

Estudo de métodos de lavra de areia e de processos de reabilitação em áreas mineradas - RMSP - 2a ${ }^{a}$ Fase. São Paulo, 1988. 2 v. (IPT. Relatório, 26.943).

Avaliação do potencial de alteração da qualidade da água subterrânea na área da Mineração Horii, Mogi das Cruzes, SP. São Paulo, 1991. 29 p. (IPT. Relatório, 29.253).

Programa de Atualização Tecnológica Industrial - PATI. Estudos setoriais Mineração. São Paulo, 1993. 280 p. (IPT. Relatório, 30.503).

Condições geológico-geotécnicas dos taludes da mineração abandonada "Giosa", no município de Embu, SP, com estimativa preliminar de custos de estabilização e levantamento de alternativas de recuperação da área. São Paulo, 1994 (IPT. Relatório, 32.478).

Considerações a respeito da estabilidade e eficiência das barragens de rejeito associadas àmineração de areia no Distrito Mineral de Araçariguama, SP. São Paulo, 1995. 12 p. (IPT. Relatório, 33.160).

INTERNATIONAL ORGANIZATION FOR STANDARDIZATION. Guide to environmental management principles, systems and supporting techniques. Génève: ISO, 1995. (ISO/DIS 14.004).

JAYAWARDENA, D.E.D.S. Mineral resources development and the environment in the Asia/Pacific region. In: SEMINAR ON CAPACITY BUILDING FOR ENVIRONMENT MANAGEMENT IN ASIAN/PACIF MINING, 1994. Jakarta. Proceedings... Jakarta: UNCTAD, 1994. p.91-99. 
JENSEN, D.R. Selecting land use for sand and gravel sites. Silver Spring: University of Illinois/National Sand and Gravel Association, 1967. (Project n. 3).

JOHNSON, C. Practical operating procedures for progressive rehabilitation of sand and gravel sites. Silver Spring: University of Illinois/National Sand and Gravel Association, 1966. (Project n. 2).

KNECHT, T. Ocorrências minerais do Estado de São Paulo. São Paulo: Instituto Geográfico e Geológico/Secretaria da Agricultura, 1950. v. 1.

KENNEDY, A. Advances in mine reclamation. Mining Magazine, London, v. 166, p.334-338, Jun. 1992

KING, T.V.V., AGER, C.M., ATKINSON, W.W. Environmental considerations of active and abandoned mine lands: lessons from Summitville, Colorado. Denver: United States Geological Survey, 1995. (USGS. Bulletin, 2220).

KUNTJORO, D. Environmental impact assessment in Indonesia. In: SEMINAR ON CAPACITY BUILDING FOR ENVIRONMENTAL MANAGEMENT IN ASIAN/PACIFIC MINING, 1994. Jakarta. Proceedings... Jakarta: UNCTAD, 1994. p.38-41.

LAL, R., HALL, G.F., MILLER, F.P. Soil degradation: I. basic processes. Land Degradation \& Rehabilitation, London, v. 1, n. 1, p.51-69, Jul./Aug. 1989

LEMOS, A.C.N., CAMPOS, H.C.N.S., BITAR, O.Y. MONFORTE, R. Planejamento e manejo minerário municipal: uma proposta para a participação do município no ordenanento e desenvolvimento da mineração. São Paulo: Sudelpa, 1986. 26 p. (Sudelpa. Boletim Técnico, 2).

LEONARDI, C.A., POLETTO, C., FREIRE, D.J.A.M., CASADEI, D.S., MATSUO, E., CHISCA JR., H., MAGLIO, I.C., CHIOSSI, N.J., STRAUSS, R., FONTES, U.P. Projetos pilotos para a recuperação de áreas degradadas pela mineração na Região Metropolitana de São Paulo. In: CONGRSSO BRASILEIRO DE GEOLOGIA DE ENGENHARIA, 4, Belo Horizonte, 1984. Anais... São Paulo: ABGE, 1984. v.1. p.94-112.

LYLE JR., E.S. Surface mine reclamation manual. New York: Elsevier, 1987. 286p.

MACEDO, A.B., BORDIGNON, J.L., NATIVIDADE, H., VALVERDE, F.M., OSTAFIUC, G.B., ANTONINI, S.A., SILVA, H.V., COIMBRA, A.M. A mineração de areia na Região Metropolitana de São Paulo: aspectos econômicos, geológicos e ambientais. In: SIMPÓSIO REGIONAL DE GEOLOGIA, 5, São Paulo, 1985. Atas... São Paulo, SBG, 1985. v.1. p.7989.

MACHADO, I.F. O DNPM e o controle ambiental na mineração. In: SEMINÁRIO BRASILCANADÁ DE MINERAÇÃO E MEIO AMBIENTE, 1, 1990, Brasília. Anais... Brasília: DNPM, 1991. p.27-28.

MACKASEY, W.O. Dealing with environmental and health and safety problems associated with abandoned mines. In: SEMINÁRIO BRASIL-CANADÁ DE MINERAÇÃO E MEIO AMBIENTE, 1, 1990, Brasília. Anais... Brasília: DNPM, 1991a. p.101-106.

Developing an appropriate legislative framework for mine closures. In: SEMINÁRIO BRASIL- CANADÁ DE MINERAÇÃO E MEIO AMBIENTE, 1, 1990, Brasília. Anais... Brasília: DNPM, 1991b. p.107-111. 
MARKER, A., CUNHA, R.C.A., GUNTHER, M.A. Avaliação de áreas contaminadas na RMSP. Saneamento Ambiental, n.25, p.36-39, 1993.

MARSH, B.E. Successful reclamation. In: SEMINAR ON CAPACITY BUILDING FOR ENVIRONMENTAL MANAGEMENT IN ASIAN/PACIFIC MINING, 1994. Jakarta. Proceedings... Jakarta: UNCTAD, 1994. p.73-74.

MARTINS, L. A.M. Administração da produção de agregados: pode a experiência de Ontário ser apropriada ao Estado de São Paulo? In: CONGRESSO BRASILEIRO DE GEOLOGIA, 37, 1992, São Paulo. Boletim de resumos expandidos... São Paulo: SBG, 1992. v.1, p.613614.

Uso y ocupación del suelo: la planificacion municipal y la mineria. In: REPETTO, F.L. et al., eds. Aspectos geologicos de proteccion ambiental. Montevideo: ORCYT/Unesco, 1995. v.1, p.125-134.

MASCARENHAS, G.R., OLIVEIRA, L.F.Q. A mineração na Região Metropolitana de Belo Horizonte e suas implicações ambientais. In: SIMPÓSIO SOBRE A SITUAÇÃO AMBIENTAL E QUALIDADE DE VIDA NA REGIÃO METROPOLITANA DE BELO HORIZONTE E MINAS GERAIS, 2, 1992, Belo Horizonte. Anais... Belo Horizonte: ABGE, 1992. p.204-207.

MASCHIO, L.M.A. Evolução, estágio e caracterização da pesquisa em recuperação de áreas degradadas no Brasil. In: SIMPÓSIO NACIONAL SOBRE RECUPERAÇÃO DE ÁREAS DEGRADADAS, 1, 1992, Curitiba. Anais... Curitiba: Fupef, 1992. p. 17-33.

MENCACCI, M.C., CARTER, R.A. Mine it - reclamain it - bank it. Rock Products, Chicago, v. 92, n. 11, p.47-56, Nov. 1989.

MORIN, D. Técnicas de restauração da qualidade das águas dos lagos e das represas. In: ECOBRASIL SÃO PAULO- CONFERÊNCIAS TÉCNICAS SOBRE MEIO AMBIENTE, 1992. São Paulo. São Paulo, 1992. p.133-153. (Publicação especial).

MUNN, R.E. Environmental impact assessment: principles e procedures. Toronto: John Wiley, 1975. 180p. (Seape. Report, 5).

MURGEL, M.C.O.L., PEREIRA, M.A.M.G., SIMONSEN, R.M., TEIXEIRA, H.R., ARAÚJO, N., BARBOUR, E.D., SOLDATELLI, L.M. O Prad no contexto da recuperação das bacias hidrográficas do Estado de São Paulo. In: CONGRESSO BRASILEIRO DE ESSÊNCIAS NATIVAS, 2, 1992, São Paulo. Anais... São Paulo: Instituto de Botânica/SMA, 1992. p. 937944.

NAKAZAWA, V.A., HELOU, G.C.N. . Erosão nas bacias dos rios Tietê e Pinheiros: aspectos físicos e antrópicos. In: SIMPÓSIO BRASILEIRO DE RECURSOS HÍDRICOS, 10, 1993, Gramado. Anais... Gramado: ABRH, 1993. 10 p.

NAKAZAWA, V.A., FREITAS, C.G.L., DINIZ, N.C. Carta geotécnica do Estado de São Paulo: escala 1:500.000. São Paulo: IPT, 1994. 2 v. (IPT. Publicação, 2.089).

ORGANIZAÇÃO DAS NAÇÕES UNIDAS. Centro de Informação das Nações Unidas no BrasilRio de Janeiro. Agenda 21: resumo da Conferência das Nações Unidas sobre Meio Ambiente e Desenvolvimento, 1992, Rio de Janeiro. Rio de Janeiro: ONU-Cinub, 1993. 45p. 
PARIZOTTO, J.A. O gerenciamento ambiental: estudo de caso de cinco empresas de mineração no Brasil. Rio de Janeiro: Cetem/CNPq, 1995. 131p. (Série Qualidade e Produtividade, 5)

PAULINA, I. Diversão ao ar livre: veja quais são os dez melhores parques da cidade para alugar uma ilha, pescar tilápias, ver plantas carnívoras, fazer caminhadas... Veja São Paulo, São Paulo, p.14-24, nov./dez. 1995.

PRANDINI, F.L., NAKAZAWA, V.A., CAMPANÁRIO, M. A. Cartografia geotécnica da Grande São Paulo. In: SEMINÁRIO SOBRE PROBLEMAS GEOLÓGICOS E GEOTÉCNICOS NA REGIÃO METROPOLITANA DE SÃO PAULO, 1, 1992. São Paulo. Anais... São Paulo: Abas/ABGE/SBG-SP, 1992. p.241-250.

RICCOMINI, C., COIMBRA, A.M., TAKIYA, H. Tectônica e sedimentação na Bacia de São Paulo. In: SEMINÁRIO SOBRE PROBLEMAS GEOLÓGICOS E GEOTÉCNICOS NA REGIÃO METROPOLITANA DE SÃO PAULO, 1, 1992, São Paulo. Anais...São Paulo: Abas/ABGE/SBG-SP, 1992. p.21-46.

RITCEY, G. Drenagem ácida de mina. In: SEMINÁRIO INTERNACIONAL SOBRE DRENAGEM ÁCIDA DE MINA, 1, 1995, Belo Horizonte. Roteiro de curso. Belo Horizonte: Ibram, 1995. 3 p.

REGIÃO Metropolitana de São Paulo já é a $2^{\text {a }}$ maior do mundo, revela ONU. O Estado de São Paulo, São Paulo, 28 abr. 1993.

ROEHRIG, J., SINGER, E.M. Técnicas de remediação de sítios contaminados. Saneamento Ambiental, São Paulo, v.7, n. 37, p.19-27, fev./mar. 1996

RUIZ, M.S. O conflito entre urbanização e mineração de argilas no município de Campinas: estudo de caso, Bairro Santa Lúcia. Campinas, 1989. 133 p. Dissertação (Mestrado) Instituto de Geociências, Universidade Estadual de Campinas.

RUIZ, M.S.; NEVES, M.R., coords. Mercado produtor mineral do Estado de São Paulo: levantamento e análise. São Paulo: Pró-minério/IPT, 1990. 188 p. (IPT. Publicação, 1822).

RUKAVINA, M. From rock to strawberries. Rock Products, Chicago, v. 94, n. 9, p.37-41, Sep. 1991.

SÁNCHEZ, L.E. Land reclamation in Brazil: current situation and future trends. In: INTERNATIONAL CONFERENCE ON ENVIRONMENTAL ISSUES AND MANAGEMENT OF WASTE IN ENERGY AND MINERAL PRODUCTION, 2, 1992, Calgary. Proceedings... Calgary: FGC/UL/UC, 1992a. p. 129-135.

Princípios de gerenciamento ambiental e sua aplicação àindústria de mineração. In: SIMPÓSIO NACIONAL DE GERENCIAMENTO AMBIENTAL NA INDÚSTRIA, 1, 1992, São Paulo. Anais... São Paulo: Signus, 1992b. p. 127-134.

A diversidade dos conceitos de impacto ambiental segundo diferentes grupos profissionais. In: CONFERÊNCIA REGIONAL DA IUAPPA, 5, 1994, São Paulo. São Paulo: IUAPPA, 1994. 12 p. (Separata).

Projetos de recuperação: usos futuros e a relação com a comunidade. In: ENCONTRO DE MINERAÇÃO NO MUNICÍPIO DE SÃO PAULO, 1, 1994. São Paulo. Anais... São Paulo: SAR/PMSP/Epusp, 1995. v. 1, p.53-83. 
SÁNCHEZ, L.E., SILVA, S.S., PAULA, R.G. Gerenciamento ambiental e mediação de conflitos: um estudo de caso. In: CONGRESSO ÍTALO-BRASILEIRO DE ENGENHARIA DE MINAS, 2, 1993, São Paulo. Anais... São Paulo: Epusp, 1993. p.475-496.

SANTOS, M. A urbanização brasileira. São Paulo: Hucitec, 1993. 157p.

SANTOS, A.R., PRANDINI, F.L., OLIVEIRA, A.M.S. Limites ambientais do desenvolvimento: geociências aplicadas, uma abordagem tecnológica da biosfera. São Paulo: ABGE, 1990. 20 p. (Artigo técnico).

SANTOS, A.R., NAKAZAWA, V.A. Erosão e assoreamento na RMSP. In: SIMPÓSIO SOBRE PROBLEMAS GEOLÓGICOS E GEOTÉCNICOS NA REGIÃO METROPOLITANA DE SÃO PAULO, 1, 1992, São Paulo. Anais... São Paulo: Abas/ABGE/SBG-SP, 1992. p.177-194.

SÃO PAULO. Secretaria de Estado dos Negócios Metropolitanos. Empresa de Planejamento da Grande São Paulo. Plano diretor de mineração: diagnóstico e diretrizes. São Paulo: DNPM/CPRM, 1980. 65 p.

Manual técnico para empreendimentos minerais na RMSP. São Paulo: SNM/Emplasa, 1982. 2 v.

SÃO PAULO. Secretaria da Ciência e Tecnologia. Instituto de Pesquisas Tecnológicas do Estado de São Paulo. Subsídios para aperfeiçoamento da legislação relacionada à mineração e meio ambiente. São Paulo: Pró-minério/IPT, 1987. 283 p. (IPT. Publicação, 1733).

SÃO PAULO. Secretaria de Estado do Meio Ambiente. Secretaria Municipal de Planejamento. Vegetação significativa no município de São Paulo. São Paulo: SMA, 1988. 560 p. (Série Documentos).

SÃO PAULO. Secretaria de Estado do Meio Ambiente. Coordenadoria de Planejamento Ambiental. Roteiro de EIA/Rima para empreendimentos minerários e Plano de recuperação de áreas degradadas: manual de orientação. São Paulo: SMA, 1991. 12 p. (Série Manuais).

SAVASTANO NETO, A., GOMES, M.C.A.A., FRISCHENBRUDER, M.T.M.; FIGUEIRA, R.M.; MICHELI. D. Planejamento urbano e plano diretor de mineração da Região Metropolitana de São Paulo. In: SEMINÁRIO BRASIL-CANADÁ DE MINERAÇÃO E MEIO AMBIENTE, 1, 1990, Brasília. Anais...Brasília: DNPM, 1991. p.112-129.

SCHELLIE, K.L. Sand and gravel operations: a transitional land use. Silver Spring: National Sand and Gravel Association, 1977. 211 p.

SCHELLIE, K.L., BAUER, A.M. Shaping the land: planned use of industrial sand deposits. Silver Spring: National Industrial Sand Association, 1968. 47 p.

SENDLEIN, L.V.A., YAZICIGIL, H., CARLSON, C.L., eds. Surface mining environmental monitoring and reclamation handbook. New York: Elsevier, 1983. 750 p.

SHIMIZU, G.Y., CARVALHO, M.A.J, SENDACZ, S., LEMOS, M.M.G., GARCIA, E., EYSINK, J. Lagoas de mineração de areia: impactos sobre os parâmetros ambientais e comunidades bióticas. In: SIMPÓSIO BRASILEIRO DE RECURSOS HÍDRICOS, 11, 1995, Recife. Anais... Recife: ABRH, 1995. v.3, p 269-274. 
SILVA, A.A., PIZÃO NETO, E., BALLANOTTI, J. L., HERNANDES, R.V., SILVA, S.S., CINCOTTO, Z. Mineração no município de São Paulo: aspectos legais e sócio-ambientais. In: PHILLIPI JR., A., coord. A questão ambiental urbana: cidade de São Paulo. São Paulo: PMSP/SVMA, 1993. p.348-364.

SILVA, I.X. , POMPEIA, S.L., AGUIAR, L.S., GOMES, J.M., VON GLEHN, H.Q.C., MACHADO, S.P., MARTINS, S.E., ARAÚJO, P.R.D. Recuperação de áreas degradadas por extração de areia no município de Jacareí - SP. In: SIMPÓSIO NACIONAL SOBRE RECUPERAÇÃO DE ÁREAS DEGRADADAS, 2, 1994, Foz do Iguaçu. Anais...Curitiba: Fupef, 1994. p.205-210.

SILVA, C.M.M. Estudo de alternativas de reabilitação para as áreas degradadas pelas minerações de argilas bentoníticas de Boa Vista, Campina Grande, PB. São Paulo, 1995. 129 p. Dissertação (Mestrado) - Escola Politécnica, Universidade de São Paulo.

SINTONI, A., VALVERDE, F.M.E., OBATA, O.R. A mineração poderá conviver com a cidade? Brasil Mineral, v. 11, n. 118, p.59-66, jul. 1994.

SISTEMA ESTADUAL DE ANÁLISE DE DADOS. Perfil municipal 1980/91: Região Metropolitana de São Paulo. São Paulo: Fundação Seade, 1993. v.1, 145 p.

SODNOMDORJ, J. The mongolian environmental impact assessment procedures and the mining industry of Mongolia. In: SEMINAR ON CAPACITY BUILDING FOR ENVIRONMENTAL MANAGEMENT IN ASIAN/PACIFIC MINING, 1994. Jakarta. Proceedings... Jakarta: UNCTAD, 1994. p.42-46.

SOUZA, V.P. Drenagens ácidas no estéril piritoso da mina de urânio de Poços de Caldas: interpretação e implicações ambientais. São Paulo, 1995. 141 p. Dissertação (Mestrado) Escola Politécnica, Universidade de São Paulo.

TAVEIRA, L., BARROS, L.H.S., SEPE, P.M. Urbanização x mineração: um conflito no meio ambiente urbano. In: PHILLIPI JR., A., coord.. A questão ambiental urbana: cidade de São Paulo. São Paulo: PMSP/SVMA, 1993. p.365-371.

TEIXEIRA, J.A.G. Impactos ambientais da atividade mineral na RMSP. In: SEMINÁRIO SOBRE PROBLEMAS GEOLÓGICOS E GEOTÉCNICOS NA REGIÃO METROPOLITANA DE SÃO PAULO, 1, 1992, São Paulo. Anais... São Paulo:Abas/ABGE/SBG-SP, 1992. p.63-75.

A atividade minerária e a relação com o poder público. In: ENCONTRO DE MINERAÇÃO NO MUNICÍPIO DE SÃO PAULO, 1, 1994. São Paulo. Anais... São Paulo: SAR/PMSP/Epusp, 1995. p.131-136.

TONSO, S. As pedreiras no espaço urbano: perspectivas construtivas. Campinas, 1994. 131p. Dissertação (Mestrado) - Instituto de Geociências, Universidade Estadual de Campinas.

TOY, T.J., HADLEY, R.F. Geomorphology and reclamation of disturbed lands. London: Academic Press, 1987. 480 p.

TRISWANDI, D. Rehabilitation of mining sites in P.T. Koba Tin. In: SEMINAR ON CAPACITY BUILDING FOR ENVIRONMENTAL MANAGEMENT IN ASIAN/PACIFIC MINING, 1994. Jakarta. Proceedings... Jakarta: UNCTAD, 1994. p.53-55.

UNIÃO INTERNACIONAL PARA A CONSERVAÇÃO DA NATUREZA. Programa das Nações Unidas para o Meio Ambiente. Fundo Mundial para a Natureza. Cuidando do Planeta Terra. São Paulo: UICN/PNUMA/WWF, 1991. 246 p. 
VALVERDE, F.M., KYOTANI, M.A. Mineração em áreas urbanas. Brasil Mineral, n. 30, p.31-36, mai 1986.

VALVERDE, F.M., MORAES, R.O., KULAIF, Y. Atividade mineral: potencialidade e explotação atual. In: SEMINÁRIO SOBRE PROBLEMAS GEOLÓGICOS E GEOTÉCNICOS NA REGIÃO METROPOLITANA DE SÃO PAULO, 1, 1992, São Paulo. Anais...São Paulo: Abas/ABGE/SBG-SP, 1992. p.57-62.

VASCONCELOS, M.M.T.; SILVA, V.C.R. da; GAMA JR., G.F.de C.; CARVALHO, P.A.S. Avaliação expedita para recuperação de área degradada: o caso de uma mineração de areia abandonada em Embu, SP. In: CONGRESSO BRASILEIRO DE GEOLOGIA, 39, 1996, Salvador. Anais... Salvador: SBG, 1996. v.4, p. 344-349.

VARGAS, M. Metodologia da pesquisa tecnológica. Rio de Janeiro: Globo, 1985. 243 p.

Para uma filosofia da tecnologia. São Paulo: Alfa Omega, 1994. 287 p.

WARHURST, A. Environmental management challenges after Rio 92: innovation and sustentainable development. In: INTERNATIONAL SYMPOSIUM ON MINING AND DEVELOPMENT, 1, 1995, Campinas. Proceedings... Campinas: IG/UNICAMP, 1995. p. 263283.

WEISSBERG, I. Estudo da reabilitação de solos em áreas bauxíticas mineradas em Poços de Caldas (MG): uma abordagem ambiental e uma contribuição técnica para otimização. São Paulo, 1995. 130 p. Tese (Doutorado) - Instituto de Geociências, Universidade de São Paulo.

WILLIANS, D.D. Reabilitação de minas de bauxita exauridas em Poços de Caldas, MG. In: SIMPÓSIO BRASILEIRO SOBRE TÉCNICAS EXPLORATÓRIAS APLICADAS À GEOLOGIA, 3, 1984, Salvador. Anais... Salvador: SBG-BA, 1984. p.464-467.

WILLIANS, D.D.; BUGIN, A; REIS, J.L.B., coords. Manual de recuperação de áreas degradadas pela mineração: técnicas de revegetação. Brasília: Ibama, 1990. 96 p.

WYANT, J.G., MEGANCK, R.A., HAM, S.H. A planning and decision-making framework for ecological restoration. Environmental Management, New York, v. 19, n. 6, p.789-796, nov./dec. 1995.

ZIMMERMAN, K. The way of the future. Rock Products, Chicago, v. 93, n. 10, p.54-57 e 83-84, oct. 1990. 
ANEXOS 
ANEXO 1

FICHA DE DADOS

\section{INFORMAÇÕES GERAIS}

1.Nome da empresa/mina/área:

2. Município/localidade:

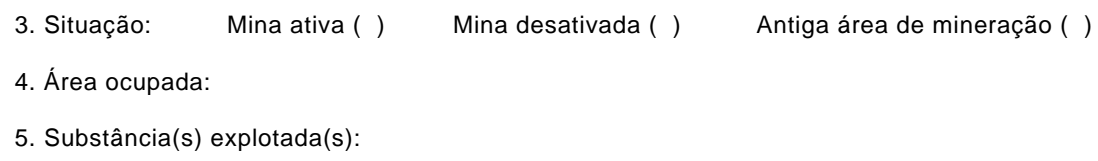

6. Características tecnológicas:

7. Produção média mensal, preço e destino/setor de consumo:

8. Ano de início da lavra:

9. Vida útil:

10. Contexto geológico-geomorfológico e aspectos geotécnicos:

11. Contexto urbano e ambiental:

12. Métodos Operacionais

12.1 Decapeamento:

12.2 Lavra:

12.3 Beneficiamento:

12.4 Disposição de rejeitos e estéreis:

12.5 Estocagem, carregamento e escoamento do produto:

12.6 Operações auxiliares: 
ASPECTOS AMBIENTAIS E MEDIDAS DE RECUPERAÇÃO

13. Conflitos:

14. Ocupação atual das áreas degradadas e das circunvizinhanças

15. Processos de degradação e impactos ambientais observados:

15.1 Impactos e indicadores:

15.2 Medidas mitigadoras adotadas:

15.3 Medidas de monitoramento

15.3.1 Indicadores ambientais monitorados:

15.3.2 Métodos e equipamentos empregados:

16. Medidas de recuperação e indicadores de desempenho

16.1 Nas frentes de lavra:

16.2 Nos depósitos de rejeitos e estéreis:

16.3 Nas áreas de infra-estrutura:

16.4 Estimativa de custos de recuperação:

16.5 Promotor/patrocinador/executor: 


\section{DADOS DO PRAD}

17. Data da elaboração:

18. Empresa executora:

19. Impactos ambientais identificados/previstos:

20. Recuperação prevista:

20.1 Medidas e uso pós-mineração:

20.2 Métodos e técnicas

20.3. Compatibilidade com uso do solo circunvizinho:

20.4 Área total a ser recuperada:

20.5 Prazo/cronograma:

20.6 Custos estimados:

20.7 Participação da comunidade:

21. Outras observações: 


\section{CONTEXTO LEGAL}

22. EIA/Rima:

23. Licenciamento ambiental (Cetesb, DEPRN, DUSM, Daia):

24. Licenciamento mineral (Prefeitura e DNPM):

25. Adequação ao Plano Diretor de Mineração da RMSP:

26. Adequação às legislações municipal, metropolitana e estadual de uso do solo:

27. Unidades de Conservação Ambiental:

28. Proprietário do solo:

INFORMAÇÕES COMPLEMENTARES 
ANEXO 2

FICHA DE ENTREVISTA

Data:

Nome:

Instituição e cargo:

1) Qual a atribuição/função da sua instituição na recuperação de áreas degradadas por mineração? Qual a base legal/missão?

2) Como vê a efetividade dessa atribuição/função nos últimos anos?

3) Poderia citar ações bem sucedidas na RMSP sobre o tema, nas quais sua instituição tenha participado? E mal sucedidas?

4) O que seria necessário fazer para aprimorar o desempenho da sua instituição no tema? E o de outras? 
5) Sob o ponto de vista tecnológico, poderia citar minerações que implementaram (ou estão implementando) boas medidas de recuperação? Que tipo de medidas?

6) Poderia citar exemplos importantes de antigas áreas de mineração na RMSP que atualmente se encontram reabilitadas ou ocupadas por outros usos do solo?

7) Outras informações adicionais 


\section{ANEXO 3 \\ RELAÇÃO DE ENTREVISTADOS}

- Airton Sintoni *, engenheiro de minas, Coordenadoria de Planejamento e Política EnergéticaCPPE, Secretaria de Estado de Energia- SEE.

. Álvaro Gutierrez Lopes * geólogo, Diretoria de Controle Ambiental, Companhia de Tecnologia de Saneamento Ambiental- Cetesb.

- Ciro Terêncio R. Ricciardi *, engenheiro de minas, empresário de consultoria e projetos, Prominer.

. Eduardo R. Machado Luz, empresário de mineração, presidente do Sindicato da Indústria de Extração de Areia no Estado de São Paulo- Sindareias.

- Elvira Gabriela Ciacco da Silva Dias, engenheira de minas, Serviço de Orientação Técnica à Consultas, Departamento de Avaliação de Impacto Ambiental- Daia, Secretaria de Estado do Meio Ambiente.

. Fernando Mendes Valverde, geólogo, Divisão de Energia, Delegacia do Ministério de Minas e Energia em São Paulo.

- Geraldo Amaral, engenheiro, Diretoria de Engenharia Ambiental, Companhia de Tecnologia de Saneamento Ambiental- Cetesb

. Ghandi Pires Fraga *, geólogo, Departamento de Proteção dos Recursos Naturais- DEPRN, Secretaria de Estado do Meio Ambiente- SMA.

. José Abílio Gouveia Teixeira, geólogo, Departamento de Uso do Solo Metropolitano- DUSM, Secretaria de Estado do Meio Ambiente- SMA.

. Marisa Mamede T. Frischenbruder *, geógrafa, Coordenadoria da Atividade Mineral, Empresa de Planejamento da Grande São Paulo- Emplasa.

- Milton Akira Kiyotani, engenheiro de minas, Divisão de Minas, Delegacia do Ministério de Minas e Energia em São Paulo.

. Neide Araújo, geóloga, Departamento de Avaliação de Impacto Ambiental- Daia, Secretaria de Estado do Meio Ambiente- SMA.

- Nilton Fornasari Filho, geólogo, pesquisador do Instituto de Pesquisas Tecnológicas do Estado de São Paulo- IPT.

. Paulo Roberto de Queiroz Serpa *, geólogo, profissional autônomo.

. Ronaldo Malheiros Figueira, géologo, Divisão de Fiscalização do Programa SOS-Mananciais, Secretaria do Verde e do Meio Ambiente- SVMA, Prefeitura do Município de São Paulo- PMSP.

. Rubens Ramos de Mendonça, biólogo, Divisão Técnica da Superintendência de São Paulo, Instituto Brasileiro do Meio Ambiente e dos Recursos Naturais Renováveis- Ibama.

. Viterbo Machado Luz, empresário de mineração, Mineração Viterbo Machado Luz Ltda. 
- Zelma Cincotto, arquiteta, Grupo de Controle da Mineração, Secretaria das Administrações Regionais- SAR, Prefeitura do Município de São Paulo- PMSP.

$\left({ }^{*}\right)$ Profissionais que forneceram informações sobre parte das questões contidas na Ficha de Entrevista (ANEXO 2). 


\section{LISTA DE FIGURAS}

\section{CAPÍTULO 1}

FIGURA 1.1 - Localização e dados gerais da Região Metropolitana de São Paulo......................2

FIGURA 1.2- Distribuição do valor da produção mineral na RMSP ..................................4

FIGURA 1.3- Principais unidades geotécnicas na Região Metropolitana de São Paulo.............7

\section{CAPÍTULO 3}

FIGURA 3.1- Etapas e procedimentos básicos na recuperação de áreas degradadas por mineração, considerando empreendimentos instalados em regiões urbanas.

\section{CAPÍTULO 5}

FIGURA 5.1- Localização das minas ativas estudadas na Região Metropolitana de São Paulo. .71

\section{CAPÍTULO 6}

FIGURA 6.1- Localização das minas desativadas estudadas na Região Metropolitana de São Paulo. 120

FIGURA 6.2- Localização das áreas degradadas ocupadas estudadas na Região Metropolitana de São Paulo

FIGURA 6.3- Localização das áreas reabilitadas estudadas na Região Metropolitana de São Paulo. 133 


\section{LISTA DE TABELAS}

\section{CAPÍTULO 1}

TABELA 1.1- Produção anual e número de minas na RMSP, segundo a substância mineral... 3

\section{CAPÍTULO 2}

TABELA 2.1 - Número de áreas estudadas, segundo o bem mineral explotado. .20

\section{CAPÍTULO 3}

TABELA 3.1- Síntese comparativa do conceito de recuperação aplicado àmineração, segundo diferentes autores. 31

\section{CAPÍTULO 4}

TABELA 4.1- Número de Prads relativos à RMSP, segundo o bem mineral e a situação da mina. 64

TABELA 4.2- Usos pós-mineração previstos em Prads na RMSP

TABELA 4.3- Número de Prads, segundo a vida útil do empreendimento e o caráter de definição do uso pós-mineração.

\section{CAPÍTULO 5}

TABELA 5.1- Relação das minas ativas estudadas.

TABELA 5.2- Minas ativas, segundo o caráter de conformidade do empreendimento em relação ao uso pós-mineração previsto em planejamento.

TABELA 5.3- Minas ativas, segundo o caráter gerencial predominante no empreendimento.

TABELA 5.4- Principais medidas de recuperação praticadas em minas ativas, segundo o grau de difusão e os respectivos contextos em que são comumente encontradas.

TABELA 5.5- Síntese do desempenho das medidas de recuperação, segundo a finalidade principal.

\section{CAPÍTULO 6}

TABELA 6.1- Relação das minas desativadas estudadas.

TABELA 6.2- Relação das antigas áreas de mineração atualmente ocupadas de forma desordenada e estudadas. 
TABELA 6.3- Antigas áreas de mineração atualmente ocupadas de forma desordenada, segundo o uso atual do solo e o bem mineral anteriormente explotado.

TABELA 6.4- Relação das antigas áreas de mineração reabilitadas ou em processo de reabilitação e estudadas.

TABELA 6.5- Áreas reabilitadas, segundo o uso atual do solo e o bem mineral anteriormente explotado

TABELA 6.6- Áreas reabilitadas, segundo o agente promotor e o bem mineral anteriormente explotado

TABELA 6.7- Quantidade de projetos de reabilitação, segundo o tipo de uso do solo e a natureza do promotor 


\section{LISTA DE FOTOS}

\section{CAPÍTULO 5}

FOTO 1 - Barreira vegetal em linha única composta de eucaliptos, instalada na divisa entre a área da mineração e a propriedade circunvizinha. Mineração de areia Viterbo Machado Luz, São Paulo (AR-07). .79

FOTO 2 -Barreiras vegetais em faixas compostas de eucaliptos (à direita) e de pinheiros (à esquerda), instaladas ao longo da via de circulação interna. Mineração de areia Viterbo Machado Luz, São Paulo (AR-07).

FOTO 3 - Barreira em faixa composta de eucaliptos, instalada entre a área da lavra e o local de disposição de bota-foras. Pedreira Embu, Embu (BT-02). .79

FOTO 4 - Barreira vegetal em linha única composta de eucaliptos, instalada entre a via de circulação interna e a pilha de estocagem do produto. Pedreira Mariutti, Itapecerica da Serra (BT-12). . .80

FOTO 5 - Barreira vegetal em linha única composta de pinheiros instalada entre a via de circulação interna e a área de estocagem do produto. Mineração de areia Ponte Alta, São Paulo (AR-26). 80

FOTO 6 - Barreira vegetal em faixa composta de eucaliptos, adensada e instalada ao longo de via de circulação viária externa à área da mineração e executada por moradores vizinhos. Mineração de areia Sarp, Barueri (AR-09)..... 80

FOTO 7 -Barreira vegetal composta de mudas de espécies arbóreas nativas, plantada sob aterro de $1,5 \mathrm{~m}$ de solo do decapeamento, instalada no limite entre a área da mineração e a propriedade vizinha. Mineração de areia Caravelas, Mogi das Cruzes (AR$01)$

FOTO 8 - Viveiro de mudas de espécies abóreas nativas. Mineração de areia Ponte Alta, São Paulo (AR-26). 81

FOTO 9 - Área objeto de arborização dispersa. Pedreira Cantareira, Mairiporã (BT14)

FOTO 10 - Escadas d'água em canaletas de concreto transversais, ao longo de taludes revegetados em antigas frentes de lavra. Mineração de areia Viterbo Machado Luz, São Paulo ( AR-07)

FOTO 11 - Plantio de pinheiros em área retaludada e com solo de alteração de sedimentos terciários (solo saprolítico ou horizonte pedológico C), resultando em sulcos erosivos entre as mudas, decorrentes da ação das águas pluviais. Mineração de areia Floresta Negra, Guarulhos ( AR-15)

FOTO 12 - Retaludamento e revegetação em solo de antiga frente de lavra com solo de alteração de rochas cristalinas (solo saprolítico ou horizonte pedológico C), com deficiências de drenagem e próximo ao substrato rochoso, resultando em erosão. Mineração de areia Pongiluppi, São Paulo (AR-25).... 
FOTO 13 - Retaludamento parcial e plantio de espécies arbóreas em solo de alteração de rochas cristalinas (solo saprolítico ou horizonte pedológico $\mathrm{C}$ ), sem sistema de drenagem, resultando em erosão e escorregamentos. Mineração de caulim MM Embu-Guaçu (KI06).

FOTO 14 - Plantio de gramíneas em talude interno da barragem de bacia de rejeitos. Mineração de areia Floresta Negra, Guarulhos (AR-15)..... .86

FOTO 15 - Plantio de gramíneas, por meio de colocação de placas em talude externo da barragem de bacia de rejeitos. Mineração de areia Viterbo Machado Luz, São Paulo (AR07).......

FOTO 16 - Eucaliptos plantados em talude externo de barragem de rejeito de mina de areia, resultando em sulcos rosivos. Mineração de areia Sarp, Barueri (AR-09)...... 88

FOTO 17 - Espécies herbáceas plantadas nos taludes externos de barragem de rejeitos. A ausência de drenagem no topo da barragem resulta em sulcos erosivos no talude. Mineração de areia Sarp, Barueri (AR-09).....

FOTO 18- Operação de decapeamento (ao alto) com a retirada do solo superficial concomitantemente à lavra (abaixo, em primeiro plano). Mineração de areia Viterbo Machado Luz, São Paulo (AR-07)...

FOTO 19 - Detalhe da foto anterior, com a retirada das camadas orgânica e argilosa do solo superficial (mais escuras) e exposição do material arenoso a ser lavrado (mais claro), cuja frente de desmonte se encontra próxima (à direita). Mineração de areia Viterbo Machado Luz, São Paulo (AR-07)...... .90

FOTO 20 - Transporte e descarga do solo superficial argiloso (laterítico; horizonte pedológico B) para alteamento e reforço de barragem de rejeito. Mineração de areia Viterbo Machado Luz, São Paulo (AR-07). .90

FOTO 21 - Seqüência da foto anterior, com espalhamento e posterior compactação do solo argiloso. Mineração de areia Viterbo Machado Luz, São Paulo (AR-07).

FOTO 22 - Pilhas de estocagem das camadas de solo orgânico (marrom) e argiloso (avermelhado), junto a viveiro de mudas. Mineração de areia Viterbo Machado Luz, São Paulo (AR-07).

FOTO 23 - Retirada dirigida de camada estéril (argila). Mineração de areia Caravelas, Mogi das Cruzes (AR-01). .91

FOTO 24 - Cava resultante de extração de argila, parcialmente preenchida com material estéril e posteriormente completada com solo superficial e areia por meio de aterro hidráulico. Mineração de argila Lopes, Mogi da Cruzes (AG-05)...... .91

FOTO 25 - Revegetação com espécies arbóreas exóticas (pinheiro),em primeiro plano. Escada d'água de concreto no talude externo da barragem de rejeito, à direita. Mineração de areia Ponte Alta, São Paulo (AR-26).

FOTO 26 - Revegetação em superfície de reforço de barragem de rejeito, com uso de mudas de espécies arbóreas nativas. Mineração de areia Viterbo Machado Luz, São Paulo (AR07) 
FOTO 27 - Transposição de rejeitos dispostos em bacias de rejeito e lançamento em áreas lavradas por meio de bombeamento hidráulico. Mineração de areia Floresta Negra, Guarulhos (AR-15) .96

FOTO 28 - Novas bacias de rejeito instaladas em antiga frente de lavra, resultantes de transposição por bombeamento hidráulico. Mineração de areia Floresta Negra, Guarulhos (AR$15)$

FOTO 29 - Canaleta de drenagem revestida de concreto para captação e condução de água e retenção de sedimentos provenientes da unidade de beneficiamento. Mineração de areia Viterbo Machado Luz, São Paulo ( AR-07). .98

FOTO 30 - Tubulação e escadas de concreto para condução das águas pluviais em área de bota fora. Pedreira Embu, Embu ( BT-02 )..... 98

FOTO 31 - Canaletas de concreto perimetrais àárea da mineração, para captação e condução das águas pluviais. Pedreira Embu, Embu ( BT-02 )... .99

FOTO 32 - Tanque de sedimentação construído a jusante do sistema de drenagem da área da mineração, exibindo notável acúmulo de sedimentos. Pedreira Alvenaria, Mairiporã (BT13) 99

FOTO 33 -Lago artificial construído a jusante do empreendimento, para retenção de sedimentos provenientes da área da mineração. Pedreira Cantareira, Mairiporã (BT-14).......100

FOTO 34 - Sistema de barramento com uso de material de bota-fora, construído em bermas e taludes a jusante da área de lavra, para retenção de sedimentos. Mineração de caulim MM, Embu-Guaçu ( KI-06 ). 100

FOTO 35 - Detalhe de canaleta revestida em pedra, instalada entre a berma e o talude, do sistema de barramento descrito na foto anterior. Mineração de caulim MM, Embu-Guaçu (KI06) 101

FOTO 36 - Barragem de terra denotada pelo plantio alinhado de espécies arbóreas exóticas, construída para reter os sedimentos provenientes de pilha de bota-fora. Pedreira Itapiserra, Itapecerica da Serra ( BT-24 ). 101

FOTO 37 - Sucessão de pequenos lagos para retenção de sedimentos provenientes de pilha de bota-fora. Pedreira Itapiserra, Itapecerica da Serra ( BT-24 )..... 102

FOTO 38 - Assoreamento em um dos lagos construídos para retenção de sedimentos provenientes de pilha de bota-fora. Pedreira Itapiserra, Itapecerica da Serra ( BT-24 )..... 102

FOTO 39 - Construção de bota-fora em bermas e taludes, contendo sistema de drenagem e revegetação. Pedreira Embu, Embu ( BT-02 )..... 104

FOTO 40 - Revegetação dos taludes de bota-fora com mudas de espécies arbóreas exóticas (eucalipto). Pedreira Embu, Embu ( BT-02 ). 104

FOTO 41 - Mesmo bota-fora da foto anterior, porém cerca de um ano após, com as mudas mais altas e a revegetação das bermas com gramíneas. Pedreira Embu, Embu (BT-02)...104

FOTO 42 - Mesmo local da foto anterior, destacando os murundus ou leiras de isolamento e a inclinação da superfície da berma. Pedreira Embu, Embu (BT-02)...... 105 
FOTO 43 - Plantio de herbáceas na porção superior de talude do corpo de bota-fora, ressaltando-se os sulcos erosivos na porção inferior. Pedreira Mariutti , Itapecerica da Serra (BT-12) 105

FOTO 44 - Revegetação em placas com herbáceas em pilha de bota-fora. Pedreira Cantareira,Mairiporã (BT-14) .105

FOTO 45 - Revegetação de talude de bota fora com uso progressivo de espécies herbáceas plantadas manualmente. Pedreira Panorama, São Paulo (BT-19). 106

FOTO 46 - Revegetação da superfície de topo da pilha de bota-fora, com o plantio direto de mudas de espécies arbóreas nativas e exóticas, mas sem colocação de solo superficial. Pedreira Itapiserra, Itapecerica da Serra ( BT-24 ). 106

FOTO 47 - Revegetação da superfície de topo da pilha de bota-fora, com plantio de espécies arbóreas nativas e olocação de solo orgânico. Mineração de areia Ponte Alta, São Paulo (AR26). 106

FOTO 48 - Sistema de tanque de retenção e separação de óleos e graxas provenientes de manutenção e limpeza de equipamentos e máquinas. Mineração de areia Ponte Alta, São Paulo (AR-26). 108

FOTO 49 - Sistema de tanque e caixa de brita para retenção de óleos e graxas. Mineração de areia Viterbo Machado Luz, São Paulo (AR-07). 108

FOTO 50 - Revegetação implantada com herbáceas (gramíneas) em talude de via de circulação interna. Mineração de areia Viterbo Machado Luz, São Paulo ( AR-07 )...... 109

FOTO 51 - Revegetação em execução com placas de herbáceas (gramíneas) em talude de via de circulação interna. Pedreira Itapiserra, Itapecerica da Serra ( BT-24 )... 109

FOTO 52 - Detalhe da foto anterior. Pdereira Itapiserra, Itapecerica da Serra ( BT-24 )...... 109

FOTO 53 - Revegetação implantada com uso de herbáceas (gramíneas) em talude de via de circulação interna. Pedreira Mariutti, Itapecerica da Serra (BT-12).....

FOTO 54 - Revegetação com uso de espécies arbóreas nativas, às margens de via de circulação interna. Mineração de areia Ponte Alta, São Paulo (AR-26).....

FOTO 55 - Abatimento ou suavização de talude marginal emerso, em lago remanescente de antiga cava em planície aluvionar. Mineração de areia Cêmica, Biritiba-Mirim (AR-02).....

FOTO 56 - Mesmo caso da foto anterior, ressaltando-se, ao fundo, as instalações de beneficiamento em operação. Mineração de areia Cêmica, Biritiba-Mirim (AR-02).....

FOTO 57 - Panorama da circunvizinhança da frente de lavra de rocha para produção de brita, cuja vegetação remanescente é manejada com vistas à sua conservação. Pedreira Mariutti, Itapecerica da Serra ( BT-12 )...... 114

FOTO 58 - Área de antiga ocupação por atividades de mineração, atualmente em processo de recuperação espontânea. Pedreira Alvenaria, Mairiporã (BT-13)....

FOTO 59 - Solo preparado para o plantio de espécies arbóreas em bermas rochosas. Pedreira Cantareira, Mairiporã (BT-14). 
FOTO 60 - Mudas de espécies arbóreas nativas plantadas em bermas rochosas de pedreiras, dispostas junto à crista do talude inferior. Pedreira Cantareira, Mairiporã (BT14) .116

FOTO 61 - Mudas de espécies arbóreas nativas plantadas em bermas rochosas de pedreiras, dispostas junto à base do talude superior. Pedreira Cantareira, Mairiporã (BT14)

FOTO 62 - Remodelamento setorizado do perfil de bancadas finais, com colocação de aterro (solo de alteração), cobertura de solo superficial e plantio de gramíneas em placas. Pedreira Cantareira, Mairiporã (BT-14).

\section{CAPÍTULO 6}

FOTO 63 - Desenvolvimento de processos de instabilização (erosão e escorregamentos) em antiga frente de lavra desativada e abandonada. Mineração de caulim Caolinita, Embu-Guaçu (KI-07) 122

FOTO 64 - Mesma área da foto anterior, destacando feições de escorregamentos. Mineração de caulim Caolinita, Embu-Guaçu ( KI-07 ).

FOTO 65 - Mesma área das fotos anteriores, destacando o assoreamento em córrego situado a jusante da mina desativada. Mineração de caulim Caolinita, Embu-Guaçu (KI07)...... .123

FOTO 66 - Área de antiga bacia de rejeitos de mineração de areia. Mineração Devechi \& Devechi, São Paulo (AR-19). 123

FOTO 67 - Ao fundo, pedreira desativada em meio urbano. Pedreira Jaguaré, São Paulo (BT03) 124

FOTO 68 - Pedreira desativada próxima àrodovia Raposo Tavares. Pedreira Firpavi, São Paulo

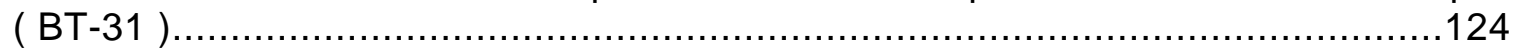

FOTO 69 - Antiga cava de extração de argila em mineração desativada. Mineração de argila Ibar, Mogi das Cruzes ( AG-03 ). .124

FOTO 70 - Notícia em jornal de bairro ("Ö Butantã"), ilustrando a carência de áreas para disposição de resíduos na cidade de São Paulo. Av. Marginal Pinheiros, São Paulo. 129

FOTO 71 - Depósito de resíduos sólidos na margem e no lago de antiga extração de areia. Ao fundo, instabilizações na frente de lavra desativada. Antiga mineração de areia Giosa, Embu (AR-16) 129

FOTO 72 - Lançamento de resíduos provenientes de desassoreamento e obras de aprofundamento da calha do rio Tietê (à esquerda), em setor desativado de lago de extração de areia (àdireita). Lago de Carapicuíba, Carapicuíba/Barueri ( AR-29 ). 129

FOTO 73 - Ocupação habitacional de baixa renda em antiga frente de lavra de areia em morro (ao fundo) e lançamento de esgotos em lago remanescente da atividade mineral (ao centro). Jardim Marilda, São Paulo ( AR-06 )..... 
FOTO 74 - Ocupação habitacional de baixa renda em frente de lavra de areia desativada no final dos anos 80, com depósito de lixo e lançamento de esgotos em lago remanescente da atividade mineral. Jardim Sabiá,São Paulo ( AR-21 )...... 130

FOTO 75 - Habitações em loteamento de baixa renda em depósitos secos de antiga bacia de decantação de rejeitos finos provenientes de extração e beneficiamento de areia da antiga Mineração Devechi \& Devechi. Jardim Noronha, São Paulo (AR-20)...... 130

FOTO 76 - Aterro sanitário de Vila Albertina instalado em área da antiga Pedreira Cantareira, São Paulo ( BT-05 )..... 136

FOTO 77 - Mesma área da foto anterior, destacando medidas e obras de estabilização (sistemas de drenos com canaletas revestidas de brita e telas de aço ). Ao fundo, ocupação de risco em expansão na Serra da Cantareira. Aterro sanitário de Vila Albertina, São Paulo (BT05)....... 136

FOTO 78 - Estacionamento e Supermercado Bergamini instalados em área de antiga pedreira. São Paulo (BT-18). 136

FOTO 79 - Mesma área da foto anterior, destacando evidências de instabilização e queda de blocos de rochas, São Paulo ( BT-18 )....... 137

FOTO 80 - Mesma área das fotos anteriores, destacando evidências de infiltração d'água e instabilização em rochas, São Paulo ( BT-18 ).....

FOTO 81 - Estacionamento e depósito de materiais de construção Madeirense, instalado em área de antiga pedreira, São Paulo (BT-17). 138

FOTO 82 - Mesma área da foto anterior, destacando feições de instabilização e queda de blocos rochosos na antiga frente de lavra,com cerca de $10 \mathrm{~m}$ de altura. Abaixo, a sinalização de advertência. São Paulo (BT-17). 138

FOTO 83 - Estacionamento e Supermercado Paes Mendonça, instalados em antiga área de extração de areia em planície aluvionar do rio Pinheiros, ainda convive com problemas de drenagem e alagamentos nas imediações,São Paulo ( AR-39 ).....

FOTO 84 - Pousada e churrascaria Serra Verde, instalada em antiga mineração de caulim, São Paulo ( KI-04).

FOTO 85 - Mesma área da foto anterior, destacando o local próximo à antiga frente de lavra, São Paulo ( KI-04 ).

FOTO 86 - Mesma área das fotos anteriores, destacando o local de outra antiga frente de lavra em processo de estabilização, São Paulo ( KI-04 )......

FOTO 87 - Mesma área das fotos anteriores, exibindo problemas de drenagem e dificuldades na estabilização de obras de contenção de aterro, São Paulo (KI-04).... 140

FOTO 88 - Galpões industriais (ao fundo) instalados em antigas bacias de rejeitos da mineração de areia Sarp. Em primeiro plano, frente de lavra da Pedreira Sarpav, Barueri (AR10) 140

FOTO 89 - Raia olímpica da Cidade Universitária, instalada em antiga área de extração de areia em planície aluvionar do rio Pinheiros, São Paulo ( AR-11).... 
FOTO 90 - Parque Cidade de Toronto, instalado em antiga área de extração de areia, São Paulo ( AR-13)

FOTO 91 - Centro Educacional e Recreativo do Butantã, instalado em área de antiga pedreira, São Paulo ( BT-04 )

FOTO 92 - Lago do Parque Ibirapuera, instalado em antiga cava de extração de areia, São Paulo (AR-09)

FOTO 93 - As instalações do Parque VillaLobos (em primeiro plano) e conjunto de edifícios (ao fundo), ambos executados em área de antigas extrações de areia em planície aluvionar do rio Pinheiros, São Paulo ( AR-28 e AR-41)

FOTO 94 - Loteamento habitacional e região comercial em área de antigos portos de areia em planície aluvionar do rio Pinheiros, São Paulo ( AR-31).... 142

FOTO 95 - Panorama aéreo da década de 80 de mineração de areia e a diversidade de tipos de uso do solo circunvizinho (habitação, comércio, industria, horticultura, rodovia, ferrovia), Itaquaquecetuba. 


\section{SIGLAS E ABREVIATURAS}

ABAS- Associação Brasileira de Águas Subterrâneas

ABGE- Associação Brasileira de Geologia de Engenharia

ABNT- Associação Brasileira de Normas Técnicas

ABRH- Associação Brasileira de Recursos Hídricos

AIA- Avaliação de Impacto Ambiental

AMD- Acid Mine Drainage

Apemi- Associação Paulista dos Engenheiros de Minas

BID- Banco Interamericano de Desenvolvimento

CBMM- Companhia Brasileira de Metalurgia e Mineração S.A.

Cepam- Centro de Estudos e Pesquisas em Administração Municipal

Cercla- Comprehensive Environmental Response, Compensation and Liability Act

Cetem- Centro de Tecnologia Mineral

Cetesb- Companhia de Tecnologia de Saneamento Ambiental

Cinub- Centro de Informações das Nações Unidas no Brasil

CNPq- Conselho Nacional de Pesquisas

Cohab- Companhia Habitacional de São Paulo

Conama- Conselho Nacional do Meio Ambiente

Condephaat- Conselho de Defesa do Patrimônio Histórico, Artístico, Arquitetônico e Turístico

Consema- Conselho Estadual do Meio Ambiente

CPRM- Companhia de Pesquisa de Recursos Minerais

CPRN- Coordenadoria de Licenciamento Ambiental e Proteção de Recursos Naturais

CVRD- Companhia Vale do Rio Doce

Daia- Departamento de Avaliação de Impacto Ambiental

DEPRN- Departamento de Proteção de Recursos Naturais

Digeo- Divisão de Geologia do Instituto de Pesquisas Tecnológicas do Estado de São Paulo

DNPM- Departamento Nacional da Produção Mineral

DUSM- Departamento de Uso do Solo Metropolitano

Edusp- Editora da Universidade de São Paulo

EIA- Estudo de Impacto Ambiental

Emplasa- Empresa Metropolitana de Planejamento da Grande São Paulo

EPA- Environmental Protection Agency (Estados Unidos; Austrália)

Epusp- Escola Politécnica da Universidade de São Paulo

EUA- Estados Unidos da América

Fapesp- Fundação de Amparo àPesquisa no Estado de São Paulo 
FAU- Faculdade de Arquitetura e Urbanismo

FSP- Faculdade de Saúde Pública

Fupef- Fundação de Pesquisas Florestais do Paraná

IAEG- International Association of Engineering Geology

Ibama- Instituto Brasileiro do Meio Ambiente e dos Recursos Naturais Renováveis

IBGE- Instituto Brasileiro de Geografia e Estatística

Ibram- Instituto Brasileiro de Mineração

IGG- Instituto Geográfico e Geológico

IG-Unicamp- Instituto de Geociências da Universidade Estadual de Campinas

IG-USP-Instituto de Geociências da Universidade de São Paulo

IPT- Instituto de Pesquisas Tecnológicas do Estado de São Paulo

ISO- International Organization for Standardization

IUAPPA- International Union of Air Pollution Prevention and Environmental Protection Associations

IUGS- International Union of Geological Sciences

MBR- Minerações Brasileiras Reunidas S.A.

MP- Ministério Público

ONU- Organização das Nações Unidas

PATI- Programa de Atualização Tecnológica Industrial

PCA- Plano de Controle Ambiental

PDM- Plano Diretor de Mineração

PMI- Departamento de Engenharia de Minas da Escola Politécnica da Universidade de São Paulo

PMSP- Prefeitura do Município de São Paulo

PNUD- Programa das Nações Unidas para o Desenvolvimento

PNUMA- Programa das Nações Unidas para o Meio Ambiente

Prad- Plano de Recuperação de Áreas Degradadas

Pró-minério- Programa de Desenvolvimento de Recursos Minerais

RCA- Relatório de Controle Ambiental

Rima- Relatório de Impacto Ambiental

RMSP- Região Metropolitana de São Paulo

RPM- Rio Paracatu Mineração S.A.

RTZ- Rio Tinto Zinco Mineração S.A.

Sama- Sociedade Anônima Mineração de Amianto

SAR- Secretaria das Administrações Regionais

SBG- Sociedade Brasileira de Geologia

SCT- Secretaria de Ciência e Tecnologia 
SCTDE- Secretaria de Ciência, Tecnologia e Desenvolvimento Econômico

Seade- Fundação Sistema Estadual de Análise de Dados

SEE- Secretaria de Estado de Energia

SGP- Secretaria de Estado de Planejamento e Gestão

SHDU- Secretaria da Habitação e Desenvolvimento Urbano

Sigesp- Sindicato dos Geólogos no Estado de São Paulo

Sindareias- Sindicato das Indústrias de Extração de Areia do Estado de São Paulo

Sindipedras- Sindicato da Indústria e Extração de Pedreiras do Estado de São Paulo

SMA- Secretaria de Estado do Meio Ambiente

SNM- Secretaria de Estado dos Negócios Metropolitanos

Sudelpa- Superintendência do Desenvolvimento do Litoral Paulista

SVMA- Secretaria do Verde e do Meio Ambiente

UICN- União Internacional para a Conservação da Natureza

UNCTAD- United Nations Conference on Trade and Development

Unesco- Organización de las Naciones Unidas para la Educación, la Ciencia y la Cultura Unicamp- Universidade Estadual de Campinas

URSS- União das Repúblicas Socialistas Soviéticas

USEPA- United States Environmental Protection Agency

USGS- United States Geological Survey

USP- Universidade de São Paulo

WWF- World Wildlife Foundation 
MAPA - Ver Pasta Desenhos 